
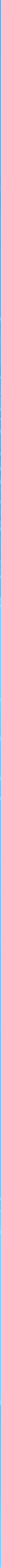



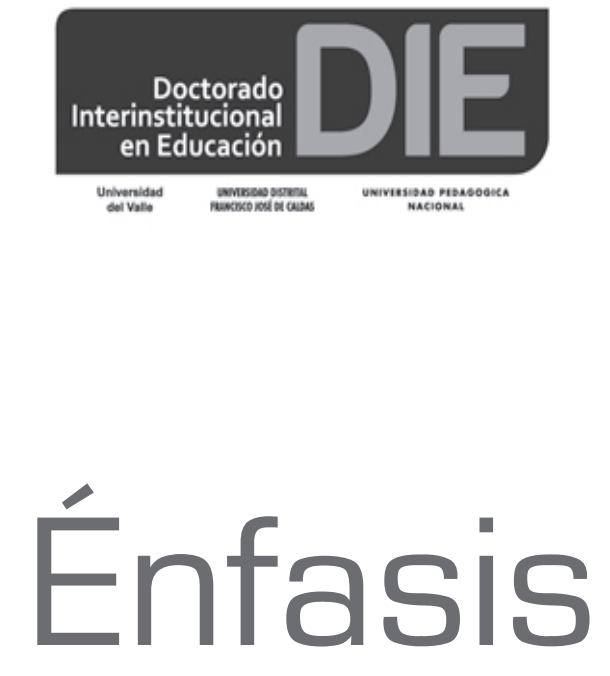

Libros de los énfasis del

Doctorado Interinstitucional en Educación 
Arias Gómez, Diego Hernán

Relatos de nación y escuela : Colombia en los imaginarios de docentes en formación / Diego Arias. -- Bogotá : Editorial

Universidad Distrital Francisco José de Caldas, 2017.

172 páginas ; $24 \mathrm{~cm}$.

ISBN 978-958-5434-15-8

1. Educación - Colombia 2. Formación profesional de maestros 3.

Sociología de la educación - Colombia 4. Identidad colectiva - Colombia I. Tít.

$371.12 \mathrm{~cd} 21 \mathrm{ed}$.

A1568635

CEP-Banco de la República-Biblioteca Luis Ángel Arango

(C) Universidad Distrital Francisco José de Caldas

ISBN Impreso: 978-958-5434-15-8

ISBN Digital: 978-958-5434-16-5

Primera Edición: Bogotá, Colombia, 2017

\section{Preparación Editorial}

Doctorado Interinstitucional en Educación

http://die.udistrital.edu.co/publicaciones

Sede Universidad Distrital Francisco José de Caldas

Aduanilla de Paiba, Edificio de Investigadores, calle 13 No. 31-75

Asistente editorial eventosdie@udistrital.edu.co

PBX: (57+1) 3239300, ext.6330-6334

\section{Fondo de Publicaciones}

Universidad Distrital Francisco José de Caldas

www.udistrital.edu.co

Carrera 24 No. 34 - 37

PBX: $(57+1) 3239300$, ext.6201

publicaciones@udistrital.edu.co

Diseño, Corrección de Estilo, Diagramación e impresión: Editorial Magisterio

Esta edición 2017 y sus características son propiedad de la Universidad Distrital José Francisco Caldas, por lo que queda prohibida la reproducción total o parcial por cualquier medio, sin la autorización previa por escrito de los editores. 


\title{
Énfasis
}

Libros de los énfasis del Doctorado

Interinstitucional en Educación

\section{Relatos de nación y escuela}

Colombia en los imaginarios de docentes en formación

\author{
Diego Hernán Arias Gómez \\ Facultad de Ciencias y Educación \\ Doctorado Interinstitucional en Educación
}

Universidad Distrital Francisco José de Caldas

Bogotá, Colombia - Abril de 2017 


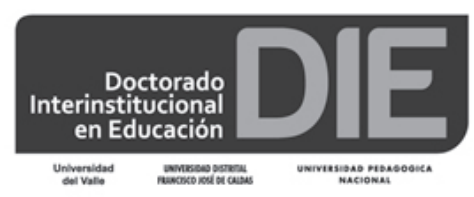

Comité Editorial-CADE

Álvaro García Martínez

Presidente CADE

William Manuel Mora Penagos

Representante de los grupos de investigación: Investigación en Didáctica de las Ciencias,

Interculturalidad, Ciencia y Tecnología-

INTERCITEC, GREECE y del Grupo Didáctica de la Química-DIDAQUIM, del Énfasis de

Educación en Ciencias.

Juan Carlos Amador Baquiro

Representante de los grupos de investigación:

Moralia, Estudios del Discurso, Filosofía y Enseñanza de la Filosofía, Grupo de investigación Interdisciplinaria en Pedagogía de Lenguaje y las Matemáticas-GIIPLyM y Jóvenes, Culturas y Poderes, del Énfasis de Lenguaje y Educación.

Rodolfo Vergel Causado

Representante de los grupos de investigación:

Grupo de Investigación Interdisciplinaria en

Pedagogía de Lenguaje y las Matemáticas GIIPLyM, Matemáticas Escolares Universidad Distrital-MESCUD y EDUMAT, del Énfasis de Educación Matemática.

Bárbara García Sánchez

Representante del grupo de investigación:

Formación de Educadores, del énfasis de Historia de la Educación, Pedagogía y Educación Comparada.

Harold Castañeda-Peña

Representante de los grupos de investigación: Aprendizaje y Sociedad de la Información y Formación de Educadores, del énfasis de ELT EDUCATION.

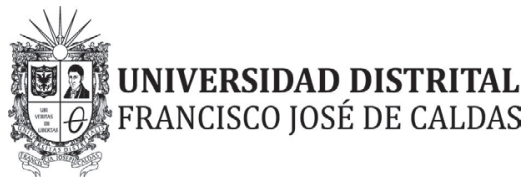

\section{Universidad Distrital \\ Francisco José de Caldas}

Carlos Javier Mosquera Suárez

Rector (E)

Giovanni Rodrigo Bermúdez Bohórquez

Vicerrector Académico

\section{Comité Editorial Interinstitucional-CAIDE}

Carlos Javier Mosquera Suárez

Director Nacional

\section{Alexander Ruiz Silva}

Coordinador DIE

Universidad Pedagógica Nacional

\section{Álvaro García Martínez \\ Director DIE \\ Universidad Distrital \\ Francisco José de Caldas}

\section{Santiago Adolfo Arboleda Franco}

Coordinador DIE

Universidad del Valle

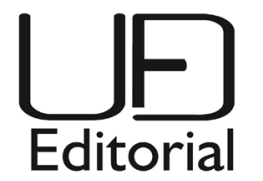


1. La identificación con la nación colombiana

1. La identidad

2. La identificación con la nación propia

3. Nación e identidad nacional en Colombia

4. Identificación con la nación propia y escuela

2. Vínculos y adscripciones a la nación propia $\quad 67$

1. Las vinculaciones identitarias con el territorio 71

2. La identificación con proyectos colectivos 82

3. La identificación con grupos cercanos 90

3. Estereotipos sobre Colombia 99

1. La cultura que nos une 100

2. Colombia es pasión 109

3. Las carencias e infamias que nos marcan 118 
4. La nación en la escuela: afectos, tensiones y subjetividad política

1. La nación en la escuela que se recuerda 132

2. La nación en la escuela que se proyecta 143

Conclusiones

Referencias 
Conocí a Diego hace casi diez años y tuve el gusto de acompañarlo en algunos tramos de su formación, entre Colombia y Buenos Aires. Recuerdo un hermoso trabajo suyo sobre los colores de las ciudadanías juveniles. Desde entonces, la paleta siguió ampliándose hasta incorporar las tonalidades complejas que hoy vibran en este libro: los sienas de las raíces, los sepias de la historia y el azul corinto del horizonte.

Celebro entonces, en primer lugar, el paso del tiempo. Eso que solemos llamar "densidad histórica" y que es condición de toda vida examina$d a^{1}$, que merezca ser vivida. ¿De qué se trata? Finalmente, de la alquimia humana: que el presente esté habitado por lo ausente, por lo que fue/ya no es y por lo que será/todavía no es.

Que la vida triunfe aun en la muerte es mérito de la cultura, en la biología siempre gana Tánatos. Bataille definió así al erotismo², y de eso mismo está hecha la historia humana y la misteriosa persistencia de sí, conatus que en lo colectivo puede transfigurarse en identidad, devenir en "comunidad imaginada" . Mundos de lucha - dolor y amor, guerra y paz, violencias y encuentros - atravesando el tiempo y que cada generación recrea, desafía o reinventa en mil y un legados, mil y una historias para seguir vivos otro amanecer.

Y pienso en Colombia, en su intensidad. Como dicen los jóvenes en este libro: en Colombia que es pasión y violencia, en los caminos y estrías que surcan su terroso vientre. Y en los colombianos, con sus miradas cálidas y sostenidas, con su alegría que enaltece esa seriedad que les viene de adentro, como de un mismo gran pozo de agua. Recuerdo entonces a mi amigo Alex Ruiz Silva ${ }^{4}$, invitando a sus connacionales a comprobar que en toda familia colombiana, en el presente o en el pasado, hay víctimas directas de alguna forma de violencia social estructural: "Créanme, no van a tardar en identificar a esas personas; quizás algunas de ellas aún están vivas, pero en cualquier caso esas personas son o fueron campesinos [...] Se van a dar cuenta de que el campesino

1 Hacemos referencia a Sócrates, quien en su apología afirmó que una vida no examinada no vale la pena de ser vivida.

2 Bataille, G. (2007). El erotismo. Buenos Aires: Tousquets.

3 Anderson, B. (1993). Comunidades imaginadas. Reflexiones sobre el origen y la difusión del nacionalismo. México: Fondo de Cultura Económica.

$4 \quad$ Director de la investigación cuyo fruto es el presente libro. 
no es un sujeto ajeno a nuestro mundo, a nuestras vidas, sino, por el contrario, alguien íntimamente cercano" ${ }^{\prime \prime}$.

¿Pero cómo se vuelve ajeno lo cercano, y cercano lo ajeno? ¿Cómo se revierte la hostilidad en hospitalidad? ${ }^{6}$ ¿Cómo conocemos, desconocemos, reconocemos en el conflicto y en la fiesta, en los que siembran y los que matan, en el territorio y en los desterrados, en el centro y en los márgenes? Tal vez sea ese - presiento- el oscuro y fresco secreto que comparten: el oleaje que agita el fondo y la superficie, que todo lo traga y todo lo escupe.

"Entonces ¿qué me amarra a mí a este país?", grita la voz de un joven desde las páginas de este libro, que creo yo que le responde: el amor y el espanto. Te amarra "Colombia", la de los que están, los que se fueron y los por llegar. Colombia plural y desigual como la imagen fractal de un caleidoscopio (ilas figuras danzan o luchan, gozan o sufren?). Colombia patria, matria, fratria. Hogar y exilio, con sus herederos y sus usurpadores. Colombia nación, con su zaga de nueve u once guerras civiles, sus más de cuatro millones de desplazados, sus violencias candentes, originarias y recientes, sus anhelos de paz. Te amarra isabes? tu propio hilo tejido y tejiendo en la "colombianidad" escarpada, hiperbólica y desigual, entramando territorios y culturas, abundancias y carencias, dignidades e infamias, fiascos y proyectos.

Y si todavía no alcanzara... te invito a seguir leyendo este libro. A mirar a los ojos de los jóvenes que mirarán los tuyos desde sus fotografías y te contarán, con la voz de Diego componiendo entre ellos, qué significa estar vivo aquí y ahora, en este lugar del mundo y de la historia.

Miriam Kriger

Conicet/CIS-IDES

Buenos Aires, Argentina.

Junio de 2016

5 Ruiz Silva, A. (2016). La tinta indeleble. Escuela y sociedad en el espacio autobiográfico. Bogotá: Aula de Humanidades.

6 Derrida, J. (1981). Políticas de la amistad. Madrid: Trotta 
La identidad nacional llegó a mis búsquedas investigativas como parte de las múltiples aristas de la formación política y la ciudadanía escolar, temas sobre los que había trabajado, investigado y escrito en la última década. El aspecto de la identificación con grupos sociales (la nación es uno de ellos) incorporó en mi haber con mayor claridad la cuestión de la articulación de la vinculación afectiva y la confraternidad hacia otros con la participación y la organización política, desde los escenarios e intereses escolares. Al principio, sin mucha emoción, el concepto de identificación con la nación propia fue resolviendo antiguos vacíos de mi producción en la línea de configuración de la subjetividad política, a la vez que me posibilitó un panorama latinoamericano y mundial cuya excusa inicial fue la pesquisa por el análisis de la construcción de nación desde la escuela, pero cuyo trasfondo siempre fue la comprensión del mundo escolar en sus variantes sociopolíticas.

Adentrarme en el tema de la identidad nacional me abrió a varias preguntas y por ende a innumerables diálogos con colegas, así como a una enorme cantidad de literatura que me ayudó a cuestionar mis propias convicciones, a dudar de ciertas apropiaciones, como el sentirse colombiano, que a fuerza de repetición por años consideré afincadas. Cuando con Alexander Ruiz, director de mi investigación, propusimos hacer nosotros mismos el ejercicio ofrecido a los estudiantes participantes de tomarnos una fotografía en la que se representara nuestra identidad nacional, después de muchos intentos solo atiné al despojo y la desnudez, con una opaca imagen de fondo que aludía a culturas milenarias. Luego de tanta reflexión sobre la identificación nacional de los otros, me quedó difícil expresar mi propia ligazón al país. La ambigüedad de la imagen reflejó mi gran desconcierto sobre mi filiación personal a ese nosotros social Ilamado Colombia.

También me sorprendieron las respuestas de los jóvenes participantes. Confieso que iba prejuiciado por encontrar desapegos, desafiliaciones o vacíos en las marcas identitarias, es fuerte el sentido común que reitera que aquí no hay identidad con la nación, pero encontré mayoritariamente lo contrario: vínculos, apuestas, afectos, incluso las ausencias se vestían de esperanza, y si bien estas filiaciones no se rendían a una nación abstracta y nominal, hallé variadas representaciones que la invocaban y en cuyo nombre estos jóvenes sentían que pertenecían a algo y que quizá así su lucha diaria tenía sentido. 
Este texto expone algunos resultados de una investigación preocupada por entender la configuración de los imaginarios sociales de nación en los relatos de estudiantes universitarios, maestros en formación; en concreto, la manera como se perfilan los vínculos y pertenencias que enuncian hacia su nación. Además, recaba en la incidencia que tiene la formación educativa en dichos esquemas de representación, es decir, cómo sus memorias escolares definen, en su presente, sus adscripciones identitarias.

Se trabajó con jóvenes universitarios que estudiaban en 2012 una carrera de licenciatura en Ciencias Sociales en una universidad pública de Bogotá, porque interesaba la forma de pensar de sujetos que recién estaban habilitados para ejercer el derecho ciudadano al voto; también, porque su formación académica podía describir configuraciones identitarias particulares, y porque importaba su condición de estudiantes para establecer una relación respecto a los afectos con su nación.

El trabajo no se centró en el análisis de aspectos teóricos sobre la construcción de nación y la identificación nacional, fue más bien la preocupación por comprender la forma como un grupo de sujetos enunciaba su relación con la nación y la vivían en su día a día. Naturalizada la condición de nacionales, los habitantes de esta Colombia no siempre se interrogan por su pertenencia, por los mecanismos que crean en ellos sentimientos de filiación y por las justificaciones morales que esgrimen al momento de ser interpelados como colombianos.

Así que es sobre el sentido de vivencia cotidiana de colombianidad que trata el presente estudio, sobre la manera como unos ciudadanos que se abren al mundo dicen experimentar su pertenencia a Colombia. Jóvenes estudiantes que fueron invitados a contar sus experiencias de filiación, sus memorias de vínculo a la nación, sus reflexiones sobre lo que significa ser colombiano o colombiana y el lugar de la educación y la escuela en esta compleja configuración. Para ese propósito de acudió a distintas modalidades de relato: oral, escrito, visual.

Esta investigación reviste crucial importancia en los tiempos que corren, porque sus resultados cuestionan ciertas verdades social y académicamente afincadas: los augurios sobre el fin de los Estados nación, el carácter supuestamente apolítico de las nuevas generaciones, la condición inconclusa de la nación colombiana y las actuales claudicaciones de los sentimientos de pertenencia a la nación de los pobladores de este país, entre otros. 
Los relatos de docentes en formación aquí analizados permitieron entender que la lealtad a la nación propia se vive de muchas maneras y que cualquier generalización no es adecuada; si alguna cabe es aqueIla que constata que estos muchachos y muchachas, que representan una pequeña parte del estudiantado de Colombia, de acuerdo a sus relatos, tienen ganas de nación, añoran en qué creer, tienen proyectos y sueños, incluso muchos usan la nación como una excusa argumentativa para reclamar la presencia de un Estado que la mayoría de las veces les resulta esquivo y ausente.

Diego Hernán Arias Gómez 



\section{LA IDENTIFICACIÓN CON LA NACIÓN COLOMBIANA}

En el Estado nacional moderno, lo que pasa por universalismo es de hecho en su génesis una especificidad, un particularismo, la diferencia de un grupo social, de clase o étnico, que consigue imponerse muchas veces por la violencia frente a otras diferencias de otros grupos sociales y con esto logra universalizarse. La identidad nacional reposa así en la identidad de la etnia dominante. Las políticas culturales y muchas otras del Estado buscan naturalizar esas diferencias bajo la forma de un universalismo, y en consecuencia transmutar el acto de violencia impositiva en un principio de legitimidad y de consenso social. La mayoría de nacionalismos y de las identidades nacionales del Estado nacional fueron construidos sobre esa base y por tanto apoyándose en la supresión de identidades rivales que no tuvieron recursos para imponerse en la lucha por las identificaciones hegemónicas.

(Santos, 2005, pp. 207-208)

\section{La identidad}

Desde una perspectiva sociológica, el concepto de identidad ha tenido un desarrollo reciente en la historia de las ciencias sociales (Altamirano, 2002). Su uso se volvió frecuente solo hasta finales del siglo XX. Los redactores del Diccionario de la lengua española, de la Real Academia, en 1734, definían la identidad como una razón en virtud de la cual son una misma cosa las que parecen distintas. Decían que la identidad era un ejercicio de la razón que consistía en la aprehensión del entendimiento sobre lo mismo en asuntos que parecían realmente diferentes. Según Altamirano, de las definiciones de identidad se desprenden dos corrientes: los esencialistas, para quienes la identidad sale de una naturaleza idéntica compartida, y los construccionistas, quienes consideran que esta se construye artificialmente en la interacción social. Aplicadas estas tendencias a la identidad colectiva habrá quien ubique los lazos vinculantes en tiempos pretéritos, inmemoriales, o quien los encuentre en los artificios y vericuetos de los poderes históricos. De cualquier manera, la identidad es hoy un concepto de uso cotidiano por políticos y académicos, es invocada con fuerza por ideologías opuestas e intereses contradictorios y pareciera dar la clave para referir, en medio de 
tiempos de crisis, lo que 'auténticamente somos' o lo que realmente 'deberíamos ser'.

Algunos analistas consideran que el problema de la identidad se puso de moda en los años sesenta del anterior siglo, fruto de la exaltación de la diferencia y el reconocimiento de una sociedad multicultural (García, 1995); para otros, este despertar debe considerarse como un efecto más del debilitamiento de los Estado naciones y como una reacción a la integración supranacional y a la mundialización de la economía (Giménez, 2002).

La noción de identidad, en términos generales, se podría entender como la imagen autorreferente que cada quien tiene de sí, pero en aras del rigor analítico es conveniente hacer algunas precisiones. La identidad no es posible captarla como un núcleo fijo y predeterminado que tipifica a los sujetos, no es una representación del yo estable e imperecedera que trasciende la historia y que se invoca desde una supuesta coherencia de la personalidad; es más y es menos. Al decir de Levi-Strauss (citado por Ortiz, 2004) "la identidad es una especie de lugar virtual, el cual nos resulta indispensable para referirnos y explicarnos un cierto número de cosas, pero que no posee, en verdad, una existencia real" (p. 77). Para Ortiz la identidad es una construcción simbólica que se hace con relación a un referente, que puede ser una cultura, una nación, un color, un género u otro colectivo. Es simbólica porque es fruto de la historia, es decir, creada, artificiosa, interesada. El llamado a una identidad 'auténtica' esboza el deseo por validar un tipo o manera de ser y pensar en oposición a otros posibles, es el esfuerzo por escoger una forma identitaria en detrimento de otras.

Desde una mirada filosófica, Charles Taylor (1989) estableció un interesante vínculo entre moral e identidad al afirmar que, al responder a la pregunta por quién se es, la identidad de un sujeto se define por los compromisos e identificaciones que dan el horizonte en el cual define lo que es valioso, deseable y bueno para él. Es decir, la identidad es un posicionamiento moral que permite ubicar, dar sentido a las acciones y valorar el mundo en el que la persona se encuentra. Cada quien se define a partir de un esquema normativo, en medio de una multiplicidad de opciones escoge aquellos valores y sentidos con los cuales se identifica y se autocalifica, de manera que la persona se apropia de unas categorías que en un momento pueden ser abstractas, pero que decide encarnar y portar. Para este autor, cualquiera sea la descripción preferida, ya sea incorporando algo en la propia vida o vinculándose 
a algo superior, siempre aparece la relación al bien, por ello moral e identidad no se pueden separar.

Tugendhart (2001) describe el concepto identidad como la orientación de la vida hacia la felicidad, señala que cada quien experimenta su vida como placentera si la ve afortunada; así, la persona percibe su identidad como lograda, aquí la felicidad no se basa en el placer, sino el placer en la felicidad. Se puede afirmar que la identidad es el valor central en torno al cual cada individuo organiza su relación con los otros sujetos y con el mundo (Giménez, 2002). Este tipo de identidad, Ilamada por algunos autores identidad cualitativa (Tugendhart, 2001), agrupa unas cualidades que el sujeto menciona en presente en virtud de sus acciones, que actualiza permanentemente y con las cuales se identifica.

Responder a la pregunta por la identidad implica emitir una respuesta por sí mismo. Es responder por quién se es, ya que "ser competente como alguien que potencialmente puede ser objeto de esa pregunta es ser un interlocutor entre otros, alguien que posee su propio punto de vista o un papel que desempeñar y que puede hablar por sí mismo" (Taylor, 1989, p. 45). En esta línea, confirma Ricoeur (2006) que "decir la identidad de un individuo o de una comunidad es responder a la pregunta: ¿quién ha hecho esta acción?, ¿quién es su agente, su autor?" (p. 997). La identidad implica tratar de declarar sin responder por otro, pues para poder responder por sí mismo uno debe saber a qué quiere responder y dónde se encuentra. Decir quién se es definir dónde se está.

En una creativa metáfora sobre la ubicación espacial, Taylor (1989) esboza un mapa de la identidad que posiciona al sujeto respecto a un territorio moral con un norte que señala coordenadas de orientación, de dónde se viene y dónde se está. Así, según el autor, lo clave "no es solo dónde estamos, sino hacia dónde vamos; y aunque lo primero puede ser una cuestión de más o menos, lo segundo es una cuestión de ir acercándonos o ir quedándonos fuera; una cuestión de sí o no" (p. 63). En esta línea argumental, es imposible la indiferencia respecto a la orientación al bien al buscar la propia identidad. En este aspecto coincide con Tugendhart (2001), para quien las identificaciones sobre algo dado "son siempre respuesta de sí o no, pero nunca de una manera simple" (p. 22). Esta ubicación es denominada por otros autores como estrategia identitaria (Giménez, 2002), pues proporciona la idea de un margen de maniobra en un repertorio siempre limitado de posibilidades, dependiendo de los recursos culturales con que cuente el sujeto para desplazarse y ubicarse en este proceso. 
Existen, por tanto, tantas identidades como ubicaciones hay respecto al espacio moral en que las personas se autodefinen. Puede haber marcos referenciales compartidos, mapas comunes, aunque la posición y la orientación de cada quien no sean las mismas, no solo porque la respuesta es personal, sino porque toda biografía es individual y los mecanismos de socialización no siempre coinciden de un individuo a otro. Lo que no es óbice para reconocer agrupamientos identitarios, en la medida en que se comparten espacios sociales más o menos comunes, como sucede en el caso de la identidad nacional.

La identidad es una construcción social, es decir, es en medio de las dinámicas sociales que los individuos construyen los aspectos constitutivos de su ser: "los significados que tendrán para mí las palabras clave serán primero los significados que ellas tengan para nosotros, es decir, para mí y mis compañeros de conversación" (Taylor, 1989, pp. 51-52). Es el lenguaje el que transmite el código común que da vida a la sociedad y por tanto las escalas de jerarquía y de valoración que socialmente se manejan. El acuerdo en los juicios acompaña el acuerdo en los significados. Sobre este particular, Bourdieu (2002) afirma que es la sociedad "quien dispensa, en grados diferentes, las justificaciones y las razones de existir; ella es la que, al producir las posiciones o los asuntos llamados importantes, produce los actos y los agentes considerados importantes, para sí mismo y para los demás" (p. 56). En consonancia con esta tesis, Hall (2003) enfatiza en la importancia del lenguaje. Para este autor las identidades son puntos de adhesión temporal a posiciones subjetivas que construyen las prácticas discursivas. La identidad, en tanto construcción social, se da en una especie de puja, compromiso y negociación entre lo interno y lo externo presente en la misma persona, entre la afirmación y la asignación identitaria, entre la 'autoidentidad' y la 'exoidentidad' (Giménez, 2002).

En relación con esta idea es clave identificar el papel del Estado en la definición y por tanto en la administración e imposición de identidades (Chihu, 2002). La configuración de los Estados implicó la construcción de nación allí donde no existía, esto es, la creación de sentimientos de vinculación, pertenencia, adhesión o identificación con las instituciones, el gobierno y el territorio. Las identidades locales fueron posibles gracias al autorreconocimiento que pudo pasar por dos vías: por la aprobación oficial o que gracias a su desaprobación impulsaron precisamente su reclamación. Es decir, la configuración de las identidades se dio por su oficialización o por la lucha por su reconocimiento en medio de un ambiente institucional que las desconocía. 
Las adhesiones y/o resistencias identitarias en términos colectivos, además de cuestiones de índole personal, pasan inevitablemente por el lugar que les da el discurso oficial a determinadas maneras de ser y pensar humanas. Por ejemplo, en las declaraciones públicas del Estado, en las reivindicaciones culturales de altos dignatarios, en el manejo que dan los medios de comunicación masivos, en el lugar que tienen en los ritos oficiales y, por supuesto, en la escuela pública y en los manuales escolares.

Hablar de identidad, en el ámbito de los Estados nación, implica destacar tres elementos que son claves para la presente investigación (Balibar, 2005):

1. Reconocer la identidad como el esfuerzo político de grupos de poder en un proceso deliberado de construcción de subjetividades, es decir, la imposición de formas de pensar, actuar y sentir. Por ello no hay una identidad dada, sino que existen identificaciones, marcas simbólicas y culturales en movimiento, intencionadas y dadas por instituciones estatales y sociales, hegemónicas y subalternas, que proveen — con diferentes niveles de éxito- sentidos de pertenencia.

2. Buena parte del contenido de la identidad, o mejor de las identificaciones, se desarrolla en el terreno cultural, con la presencia de dos categorías: los rasgos de hábito, en los que prácticas y discursos se ritualizan para forjar un sentido de pertenencia a una comunidad como una naturaleza o sustancia común. Esta categoría es denominada por Balibar (2005) como etnicidad ficticia, en tanto expresa el deseo de crear marcas visibles, audibles o sensibles que distinguen un nosotros de los otros. La segunda categoría son los rasgos de creencia o de fe que impulsan una fraternidad simbólica con cierto sentido trascendente, inspirado por un Ilamado superior y por voces autorizadas que enuncian el deber ser. Esta categoría tiene que ver con el patriotismo, según el autor, es decir, con la identificación con la nación como comunidad trascendente, transhistórica, que tiene un destino prefijado y que amerita luchas y sacrificios para mantenerse, transformarse o cualificarse.

3. Correlato de lo anterior, no hay identidad sin que se establezca una jerarquía en las referencias y las pertenencias comunitarias, o sea que cualquier sistema de pretensión de dominación identitaria no es total, pues si bien no solo coexisten en la sociedad diversos proyectos que luchan por imponerse, estos son asimilados o repelidos en distintos niveles y grados dependiendo de los grupos y personas en los que se asienten. 
El papel social de la identidad fue también analizado por Norbert Elias (1990), quien en términos de la relación del individuo y la sociedad ilustró el absurdo de considerar a los sujetos por fuera del grupo que los define. Bien sea en las sociedades tribales, en las que el grupo garantizaba la supervivencia de los individuos, o en las sociedades modernas, que produjeron crecientes procesos de especialización e individualización, la identidad del yo no puede existir sin la identidad del nosotros, ya que,

la palabrita "yo" carecería de significado si al pronunciarla no se tuvieran en cuenta otros pronombres personales que remiten a otros seres humanos. La doble forma del nombre muestra con bastante claridad lo que en el fondo es evidente, que cada ser humano procede de un grupo de otros seres humanos, cuyo nombre lleva, como apellido, al lado de su nombre de pila individualizador (Elias, 1990, p. 212).

Al ser una construcción personal en interacción con lo social, toda identificación es además una identidad narrativa, en varios sentidos, principalmente porque el sujeto que se busca se enuncia en un discurso, en una historia contada. Responder a la pregunta por la identidad implica conocerse, que a su vez "consiste en interpretarse a uno mismo a partir del régimen del relato histórico y del relato de ficción" (Ricoeur, 1999, p. 215). Al ser un relato que da cuenta de la dimensión temporal de la vida, la narración deja de ser un asunto secundario, para constituirse en la superficie de emergencia de la identidad misma; al darse una coordinación entre el relato y el sujeto "la identidad de la historia forma la del personaje" (p. 218). Y la trama se pone al servicio del devenir de la persona que se narra y que se interpreta a sí misma. Según este autor, la historia personal, como toda historia, imita en su construcción y en su escritura los modos de la trama recibidos de la tradición literaria, y ello no representa una debilidad, todo lo contrario, es su condición de realización: "La historia narrada dice el quién de la acción. Por lo tanto, la propia identidad del quién no es más que una identidad narrativa" (Ricoeur, 2006, p. 997).

Entender la identidad como identidad narrativa permite ver la articulación de la historia personal como parte de una narración más abarcadora. Al respecto afirma Appiah (2007) que "la posibilidad de contar una historia de vida que engrane con narraciones más amplias es importante para los habitantes de todo el mundo" (p. 119). Entender la trama de la identidad personal, identificar así quién se es, pasa por entender el vínculo con el grupo, con el colectivo al cual se adscribe, se pertenece o se desea pertenecer, lo que para el caso del presente es- 
tudio remite inevitablemente a la cuestión de la identidad nacional y al ente político-cultural que lo determina: la nación. Por ello es pertinente analizar las distintas gramáticas que se han fabricado sobre la identidad nacional, tema del próximo apartado.

\section{La identificación con la nación propia}

La identidad nacional, como la individual, son construcciones históricas, movimientos intencionados que nombran pertenencias grupales y que trazan líneas caprichosas entre un nosotros y un ellos. Esta analogía es defendida por Glover (2003), para quien "las naciones y las personas no son solo similares por el hecho de que no exista un alma nacional o un ego metafísico. Se parecen también por el hecho de ser, hasta cierto punto, más artefactos que cosas cuya naturaleza nos venga dada" (p. 35). Esta construcción, dirigida en gran parte por el Estado, recoge distintos recursos disponibles para generar sentimientos de adhesión y pertenencia; dichos recursos pueden variar de una nación a otra o de un período a otro, dependiendo de los intereses en juego. La etnicidad, la lengua, la religión, el pasado, el proyecto por construir, la discriminación padecida, los héroes fundadores o liberadores, la tragedia o la gloria común, entre otros, son aspectos que se pueden invocar para este propósito (Hobsbawm, 1994b). Ernest Renan (1882) dijo hace más de un siglo que olvidar, incluso interpretar mal la historia, era un factor esencial para la formación de una nación, pues las naciones eran entidades históricas de relativa novedad que fungían como muy remotas. Por su parte, para Gellner (1988) el nacionalismo tiene amnesias y selecciones propias que, pudiendo ser rigurosamente seculares, pueden ser también profundamente deformadoras y engañosas.

La identidad nacional es una modalidad de identidad social, es decir, una identidad referida a un colectivo. Es importante afirmar con Appiah (2007) que la identidad colectiva precede a la identidad cultural; en otras palabras, las supuestas diferencias que se establecen entre los individuos, con respecto a raza, etnia, lengua, religión, son posteriores a la creación de un sentimiento de identificación grupal. Para que se empiecen a dar las identificaciones culturales se requiere la instalación previa de mecanismos de clasificación y etiquetamiento social, de manera que,

lo que puedo hacer intencionalmente depende de qué conceptos tengo a mi disposición; y entre los conceptos que pueden configu- 
rar mi acción se halla el concepto de una cierta clase de persona y de cuál es la conducta apropiada para una persona de esa clase (Appiah, 2007, p. 116).

Mediante este mecanismo opera en cada integrante del grupo social una especie de autoconciencia clasificatoria, que no solo se pregunta y se responde por la pertenencia a tal o cual grupo, sino que atiende al comportamiento en consecuencia con dicha adscripción. Una vez aplicadas y vividas las etiquetas, vienen los efectos sociales y psicológicos, que contribuyen a perfilar las formas en que las personas se conciben a sí mismas y conciben sus proyectos. Así, para Appiah (2007), "parece correcto Ilamar 'identificación' a este proceso, porque la etiqueta desempeña un papel en la configuración de la manera en que el agente toma decisiones acerca de cómo lleva una vida, es decir, en el proceso de construcción de la identidad propia" (p. 117).

En esta misma línea, Bourdieu (1981) imagina la nación como un complejo resultado del procesamiento del discurso hegemónico históricamente decantado, que obra con la capacidad de definir procesos de clasificación y distinción en una sociedad particular. La capacidad del poder de describir una realidad se usa como prescripción, pues

\begin{abstract}
el paso del estado de grupo práctico al estado de grupo instituido (clase, nación, etc.) supone la construcción del principio de clasificación capaz de producir el conjunto de propiedades distintivas que son características del conjunto de los miembros de ese grupo y de anular al mismo tiempo el conjunto de propiedades no pertinentes que una parte o la totalidad de sus miembros poseen por otros títulos (por ejemplo, propiedades de nacionalidad, de edad o de sexo) y que pudieran servir de base a otras construcciones (p. 3).
\end{abstract}

Según Appiah (2007), para que sea posible la identidad colectiva se requieren, siguiendo esta idea, varios elementos. Primero, la existencia de un discurso público, es decir, que el grupo de pertenencia cuente con un espacio social de reconocimiento, de identificación respecto a otras formas de adscripción, y se cuente con cierto consenso respecto a las características que los definen; aquí se podría hablar de una identificación interna y una externa, interna porque los del grupo se ven entre ellos como parte de un colectivo, y externa porque otras agrupaciones los conocen haciendo posible distinguirse de ellas. En segundo lugar, se necesita la interiorización de la etiqueta como parte de la identidad individual de algunos de los miembros destacados, aspecto que constriñe a los miembros del grupo a obrar o hablar de tal o cual manera. Se 
dan así algunos componentes que distinguen a este grupo de los otros que sus miembros se interesan en portar. Como tercer elemento, los patrones de conducta que imponen un trato especial a quienes pertenecen al grupo. Maneras de ser actuar, hablar y comportarse propias de un colectivo se van internalizando en las personas del grupo.

La identidad nacional no es un estado fijo, ni algo con lo que se nace, consiste más bien en "un proceso de subjetivación dinámico, cambiante, en el que se tensionan tradiciones políticas, demandas sociales y proyecciones de futuro" (Ruiz, 2007, p. 95). La valoración sobre el pasado comporta un enorme peso en esta armazón, pues, al decir de Ruiz (2009), al tiempo que las comunidades son creadas y sostenidas por sus propias invenciones históricas, estas determinan, al menos en parte, sus cursos de acción, es decir, a partir de esta mirada retrospectiva son las necesidades del presente las que dinamizan el conjunto de relatos que dan soporte a la identificación nacional.

Anthony Smith (1997) definió la identidad nacional como algo multidimensional, imposible de reducir a un único aspecto, y propone una serie de elementos clave a la hora de hablar de ella en las sociedades occidentales. En primer lugar, se necesita la imagen de territorios compactos y bien definidos, "el pueblo y el territorio tienen [...] que pertenecerse mutuamente" (Smith, 1997, p. 8), pero no se trata de cualquier territorio, se trata de uno histórico, la 'patria', depositaria de recuerdos, asociaciones mentales y lugares sagrados. Un segundo elemento es una comunidad de leyes e instituciones colectivas de carácter regulador, que es acompañado por la aparición de un sentido de igualdad legal en los miembros de la comunidad (ciudadanía). Y como tercer aspecto, una serie de valores y tradiciones comunes, esto es, "una cierta dosis de cultura colectiva y una ideología cívica, una serie de suposiciones y aspiraciones, de sentimientos e ideas compartidos que mantengan unidos a sus habitantes en su tierra natal" (p. 10). El encargo de asegurar este último aspecto, según el autor, está básicamente en manos de la escuela y los medios de comunicación de masas.

Las sociedades no occidentales o étnicas, como las denomina Smith (1997), destacan la comunidad de nacimiento y la cultura nativa como elementos de la identidad, ponen énfasis en el linaje, en una ascendencia común y no tanto en el territorio; además, la lengua y las costumbres ocupan en estos colectivos el papel que desempeña la ley en las naciones occidentales. Para el autor, unas y otras cuentan con presupuestos comunes que permiten identificar las principales características de la identidad nacional (p. 12): 
1. un territorio histórico, o patria;

2. recuerdos históricos y mitos colectivos;

3. una cultura de masas pública y común para todos;

4. derechos y deberes legales iguales para todos los miembros, y

5. una economía unificada que permita la movilidad territorial de los miembros.

A diferencia del Estado, que se asocia a las instituciones públicas y al monopolio de la coerción, la nación ${ }^{1}$ une a la comunidad política con un vínculo cultural e histórico. Distinción importante porque, según Connor (citado por Smith, 1997), para los años sesenta del siglo XIX solo el diez por ciento de los Estados eran auténticos Estados nación, en el sentido de que sus fronteras coincidían con las de la nación y toda la población compartía una sola cultura étnica.

Según Smith, la identidad nacional tiene funciones internas y externas. Las externas son territoriales, económicas y políticas; las internas tienen que ver con la socialización de sus miembros por medio de los sistemas de educación, a través de los cuales se espera inculcar en los sujetos adhesión a los valores patrios:

[...] se recurre a la nación para establecer un vínculo social entre individuos y clases basado en los valores, símbolos y tradiciones compartidos. La utilización de los símbolos (banderas, monedas, himnos, uniformes, monumentos y ceremonias) recuerda a los miembros el patrimonio y el parentesco cultural que comparten, y hace que se sientan fortalecidos y enaltecidos por un sentimiento de identidad y pertenencia común. La nación se convierte en un grupo 'que logra lealtades', capaz de superar obstáculos y dificultades (Smith, 1997, p. 15).

La identidad nacional contribuye a perfilar identidades individuales gracias al impulso de una especie de personalidad colectiva. Esta implicación se configura a partir de los elementos que provienen de unos intereses grupales, que son, como se ha visto, fuertemente condicionados por el Estado, pues este "tiene una verdadera obsesión por el

1 Definida por Smith (1997) como "un grupo humano designado por un gentilicio y que comparte un territorio histórico, recuerdos históricos y mitos colectivos, una cultura de masas pública, una economía unificada y derechos y deberes legales iguales para todos sus miembros" (p. 13). 
control de la identidad de sus ciudadanos, Ilegando en ocasiones a fabricar documentos de identidad infalsificables" (Giménez, 2002, p. 41), en cuyo caso puede darse una monoidentificación, bien porque se reconoce una sola identidad legítima, o porque se tiende a aplicar etiquetas mínimas a grupos que habitan el territorio.

Smith (1998) define la identidad nacional como la "reproducción, transmisión y reinterpretación constante del conjunto de valores, símbolos, recuerdos y mitos compartidos que componen el legado étnico característico de las naciones" (p. 639), así como la identificación de las personas con ese legado particular y su reserva de recuerdos, mitos, valores y símbolos. Esta reserva se nutre a partir de las ceremonias de remembranza, los monumentos (conmemoración de los muertos) y la configuración del paisaje-territorio (historización de sitios naturales), con la intención de tejer una relación íntima y poderosa entre los muertos, los vivos y los que aún no han nacido. Según Smith, deben existir elementos históricos y étnicos inobjetables para poder configurar una identidad nacional.

Por su parte, Anderson (1993) considera que la nación es "una comunidad política imaginada como inherentemente limitada y soberana" ( $p$. 23), destacando su carácter de artefacto cultural, creado, contingente. Comunidad, porque la nación se concibe en una relación horizontal, de compañerismo con los connacionales; imaginada, porque los pobladores, al imaginar una comunión con miles y millones de personas que no conocen ni conocerán, crean una conexión abstracta que teje vínculos más allá del contacto directo; limitada, porque toda nación tiene fronteras finitas, aunque flexibles, más allá de las cuales se encuentran otras naciones; y soberana, porque el término surge en un contexto de ruptura frente al orden dinástico jerárquico y religioso.

Reforzando el carácter inventado de la nación, Villareal y Apodaka (2004) sustentan que la nación moderna se constituye como una fórmula ideal con el Estado y que se impone como un programa de gobierno; en este sentido, la nación se imagina anterior al Estado, previa a su constitución: "Francia rebusca en los galos, España en los iberos o en las cuevas de Atapuerca, Italia en la Roma imperial. Cuando la historia del territorio no ayuda, se rebusca en la historia del 'proyecto'" (p. 150).

Históricamente la formación de los Estados ha pasado por la centralización de la autoridad en un gobierno político; en tal sentido, este se constituyó mediante un proceso de monopolización e imposición 
que procuró romper las viejas fidelidades con la socialización de un discurso y unas prácticas que perseguían la fidelidad de los asociados. Las instituciones sociales de la nación moderna tuvieron como misión desarrollar los sentimientos que permitieron articular a los individuos en una nueva comunidad, en un nuevo cuerpo político, en algunos casos ajeno y abstracto. Donde existieron los antiguos vínculos religiosos, étnicos o tribales fueron gradualmente reemplazados, por mediación del Estado, en una 'religión cívica', en un vínculo laico, donde no fueron creados.

Hobsbawm (1991) coincide con los anteriores autores al otorgar un papel clave a los nacientes Estados en la conformación de estos sentimientos que configuraron la identidad nacional, ya que estos llegaban a todo el territorio por medio de sus agentes: el policía, el cartero, el empleado del ferrocarril, el militar y el maestro de escuela. Por ello "el gobierno y el súbdito o ciudadano se veían vinculados inevitablemente por lazos cotidianos como nunca antes había ocurrido" (p. 90), gracias a los censos, los registros, los empadronamientos, los ritos civiles que reemplazaron a los religiosos, y el aumento de las comunicaciones, entre otros. Vínculos civiles reemplazaban cualquier tipo de filiación anterior, fueran ellos tribales, monárquicos o religiosos.

\begin{abstract}
Muerto el rey por qué seguir manteniendo ninguna fidelidad al cuerpo decapitado del Estado. ¿Qué podría justificar la permanencia de las vinculaciones de fidelidad a una persona ahora como vinculaciones a un aparato? Los nuevos propietarios del Estado no tardaron mucho en cortar otras cabezas, pero la justificación estaba dada de antemano; el Estado por fin había sido recuperado por su verdadero dueño: la Nación o la Sociedad. Desde ese momento se establece una doctrina de Estado que mezcla las tradiciones dinásticas y las metáforas de la sangre, el linaje y la familia, con las del cuerpo místico (Villareal y Apodaka, 2004, p. 153).
\end{abstract}

Esta nueva realidad forjó varios imperativos políticos. Para formar una burocracia técnico-administrativa de acuerdo a las necesidades nacionales, se requería una lengua escrita y una alfabetización universal. Esta vía fue un importante mecanismo de homogeneización e identificación con la nación allí donde fue posible. De igual manera, ante el deterioro de las tradicionales formas de legitimación fue necesario crear una lealtad al Estado, o a sus gobernantes, máxime cuando se empezaba a hacer uso de los derechos de los ciudadanos y cuando los intereses del Estado pasaron a depender del individuo corriente, se dio la situación de que "el Estado y las clases gobernantes compitieran con rivales por la lealtad de las clases inferiores" (Hobsbawm, 1991, p. 92). 
Surge así una nueva religión, de lealtad cívica (patriotismo), provocada ante las nuevas situaciones y como compensación a la desintegración de antiguos vínculos sociales. A fuerza de volverse pueblo, los ciudadanos fueron convertidos en una comunidad y sus integrantes gradualmente "encontraban cosas en común, lugares, costumbres, personajes, recuerdos, señales y símbolos" (p. 99) reales o imaginados.

Lugar especial en este movimiento histórico ocupa la escuela, que hace parte de la eficaz maquinaria del Estado para difundir una imagen necesaria de nación, inculcar adhesión en los ciudadanos, unir en torno a una bandera y unos rituales patrios y, por supuesto, afianzar la perpetuación de tradiciones. Aquí la imposición de una única lengua para las masas, válida para asuntos económicos, administrativos y tecnológicos, no era solo un asunto pragmático, sino en especial político.

La escuela hizo real el funcionamiento del aparato del Estado para que una comunidad se convirtiera en nación: "El nacionalismo lingüístico se refería [...] a la lengua de la educación pública y el uso oficial" (Hobsbawm, 1991, pp. 104-105). También fue importante el papel desempeñado por los censos, pues al preguntar en ellos por la lengua, dichos instrumentos obligaban a los pobladores a elegir no solo una nacionalidad, sino una nacionalidad lingüística.

Pese a la fuerza del discurso oficial, la identidad nacional no necesariamente coincidió con los modelos canónicos impuestos por el Estado, existieron múltiples maneras y grados de experimentar la pertenencia a una nación. Hubo modos meramente instrumentales de invocarla; los hubo de adhesión colectiva, como miembros de un grupo étnico, por ejemplo; hubo también vínculos a nivel político en personas que vivían ideológicamente la lealtad a las instituciones del Estado nación; y hubo adhesiones preponderantemente sentimentales que involucraron fidelidad a la historia, a las tradiciones y los símbolos. Según el autor, los grados de identificación con la nación pueden ir de lo cognitivo (sin consecuencias prácticas) a la aceptación de compromisos, que pueden ser rituales o tener un carácter militante, efervescente y pasional.

En síntesis, la identidad nacional se entiende como un discurso que decanta una lucha en la que varios actores sociales se disputan la imposición de significados; maneras de ser, de pensar, de sentir. La identidad nacional es una modalidad de subjetividad política creada que se pregunta por la pertenencia y el vínculo a la nación, que responde por el lugar del nosotros y los otros en esa tensión, que define una representación de sí mismo. La nación deja de ser un abstracto cuando es 
interpelada en la subjetividad, en la identidad, porque ella es narrada de muchas maneras y porque revela biografías y socialidades que son particulares, pero que también pueden ser colectivas.

En tanto proyecto político-cultural, la construcción de nación es un proceso conflictivo que puede promover identidades tan diversas y fragmentadas como la nación misma. Lo político remite al poder y lo cultural a los innumerables escenarios en los que la identidad se manifiesta. En la identidad nacional confluyen la política y la cultura, no se pueden separar y por ello no hay identidades planas, homogéneas, totalmente hegemónicas o sometidas, tampoco totalmente subvertidas, revolucionarias. Hay matices, colores, niveles, jerarquías. Los partidos de izquierda, los movimientos sociales y populares, las agrupaciones barriales y culturales, encarnan una fuerza cualitativamente importante a la hora de definir proyectos alternativos de nación y por tanto para configurar identidades particulares. Mirar de cerca el entramado de estas es atender la brega de múltiples actores por construir nación. En términos de Bolívar (2001), "es aquí en donde empieza la pregunta por aquellos autores que indagan por las formas en que la idea de nación se inscribe culturalmente y se experimenta en la vida diaria" (p. 21).

La idea de nación cumple su papel de dominación cuando logra naturalizarse como algo no político. Clasificaciones, diferenciaciones, valoraciones, inclusiones, exclusiones, discriminaciones, gustos, etc., hacen parte de algunos presupuestos cognitivos que, creyéndose espontáneos, son en realidad construcciones sociales fruto de pautas simbólicas por recortar la realidad y que se refractan en un sentimiento de pertenencia personal y social. Por su parte, proyectos alternativos que configuran nuevas identidades en sus militantes o en sus simpatizantes, pero que se irradian en el amplio espectro de la cultura, no solo provocan fisuras en la lógica dominante, sino que promueven nuevas jerarquizaciones, prescripciones, deseos y cosmovisiones que en ocasiones conviven y en otras se imponen a los discursos imperantes. Mezclas y roces que no pocas veces suceden gracias a o contra la escuela como institución social.

Hasta acá se ha teorizado sobre la identidad como concepto que permite entender la imagen autorreferente que los sujetos construyen y narran sobre sí, en buena parte configurada por las representaciones e imaginarios que el poder, especialmente político, teje en ellos; también se ha ido un poco más allá, al reflexionar sobre la identidad nacional, en tanto categoría que enmarca los límites, las características y las adscripciones colectivas que grupos sociales tributan a sus Estados en 
forma de sentimientos de admiración y pertenencia. A continuación se propone una profundización en el concepto a partir de la producción teórica que lo analiza en relación con el contexto colombiano.

\section{Nación e identidad nacional en Colombia}

Los límites entre las fuerzas que impulsan la construcción de nación y la identidad nacional son porosos y en ocasiones invisibles. La nación solo fue posible cuando en sus habitantes fue inculcado por múltiples vías un sentimiento de adhesión y vínculo hacia varios símbolos que le evocan pertenencia a un territorio ${ }^{2}$. 'Hemos hecho Italia, ahora tenemos que hacer los italianos', fue la frase del Parlamento de aquella nación que citó Hobsbawm (1991) en un texto clásico de su autoría, para explicar el tipo de nacionalismo que surgió después de 1880 en Europa y que puso en evidencia la artificialidad y la movilización de sentimientos de pertenencia colectiva necesarios para la creación de cualquier tipo de sentimiento hacia la nación. Invocaciones a una raza, una lengua, una religión o a un pasado común son algunos de los aspectos que han abanderado intelectuales, políticos y grupos de poder en las historias nacionales para crear o afianzar relatos sobre la nación propia.

La mayoría de estudios que se han preocupado por entender la construcción de nación en el mundo de las ciencias sociales ha destacado la importancia de los procesos históricos. Es claro que las naciones no siempre han existido, y que por tanto es posible identificar su génesis y desarrollo; además, rastrear las fuerzas de distinto orden que condicionaron su trasegar y afianzamiento.

En el caso colombiano, la mayor parte de los analistas le han otorgado un lugar destacado al fenómeno de la violencia de los últimos ciento cincuenta años como elemento determinante en la construcción de nación. Se pueden observar dos grandes tendencias: quienes asumen el carácter incompleto de construcción de la nación (a causa o consecuencia de la violencia), que captan lo que le faltó al país para llegar a ser una nación (Urrego, 1998, 2004; Múnera, 1998; Erazo, 2008), y

2 Renan (1882) afirmó hace más de un siglo que "las naciones, entendidas de este modo, son algo bastante nuevo en la historia: la Antigüedad no las conoció; Egipto, China, la antigua Caldea no fueron naciones en ningún grado. Eran multitudes guiadas por un hijo del sol o un hijo del cielo. No hubo ciudadanos egipcios, así como no hay ciudadanos chinos. La Antigüedad clásica tuvo repúblicas y realezas municipales, confederaciones de repúblicas locales, imperios; apenas sí tuvo la nación el sentido en que nosotros la comprendemos" (p. 2). 
por otro lado quienes la entienden como una formación histórica, sin deudas y sin excedentes, diferente y particular como todas las naciones, aunque con la violencia como marca peculiar de configuración (González, 2001, 2004a, 2004b; Jiménez, 2005; Palacios, 2003; Melo, 1989; Patiño, 2005). En otras palabras, se juega el reconocimiento de la importancia que algunas producciones le dan a otras naciones (especialmente del Norte) como referentes, pues algunos teóricos consideran que ellas sí pudieron cerrar el ciclo para constituirse como tales; y por otra parte, quienes le otorgan a toda nación (europea, africana o americana) la contingencia histórica que le corresponde, esto es, el reconocimiento a los conflictos, intereses, poderes, fracturas y necesidades que tuvieron que sortear en un contexto social y geográfico específico. Para estos últimos no existen naciones más íntegras o completas que otras; a su vez, en este grupo hay quienes destacan variados momentos y actores en su configuración: unos ubican el nacimiento de la nación colombiana a finales del siglo XIX o principios del XX (González, 2004b), quienes le dan importancia al papel de los intelectuales en su conformación (Arias, 2005; Jiménez, 2005), o a la Iglesia (Arias, 2005; Palacios, 2003), y quienes definitivamente recalcan la violencia de mediados del siglo XX como fenómeno detonador de los primeros rasgos nacionales de identidad (Melo, 1989; Patiño, 2005). Veamos.

Sobre el carácter incompleto de la nación colombiana Alfonso Múnera (1998) argumenta que el fracaso en el intento de construcción de nación en Colombia se debió básicamente a que la Nueva Granada nunca existió como unidad política, lo cual conllevó a que cuando se rompió el vínculo con la corona española no apareciera una élite criolla con un proyecto nacional, sino varias élites regionales con planes e intereses diferenciados, de manera que el enfrentamiento entre federalistas y centralistas era la fachada ideológica que tapaba la vieja lucha colonial entre las élites locales y regionales por consolidar su autonomía y su lucha con los poderes centrales por armar un gobierno único en los Andes. La guerra entre centralistas y federalistas para nada constituía un enfrentamiento por aspectos ideológicos exclusivamente, ni solo tenía que ver con credos políticos. Múnera ejemplifica esta tensión con la lucha de la élite cartagenera para quedar como capital del Virreinato y luego de la Nueva Granada. Dada su privilegiada posición geográfica, en contra de la provincia de Santa Fe con las mismas pretensiones, los cartageneros estaban orientados a lograr una independencia respecto a las políticas comerciales que les imponía el centro y no hacia un deseo de libertad respecto a la metrópoli española. 
Para el autor, tal fragmentación puso en evidencia la ausencia de una clase hegemónica capaz de unificar e integrar la nación, como quedó demostrado con la llamada 'patria boba' (1810-1816), que lejos de representar la inexperiencia e inmadurez de los neogranadinos para regir los destinos de un territorio, expresa más bien los enfrentamientos, desatinos, desacuerdos y luchas de las distintas regiones por imponerse o rechazar las imposiciones de otras élites locales. La idea de nación que sobrevivió fue la resultante de estos conflictos político-militares por convertirse real y simbólicamente como centro. Esta tesis coincide con la lectura de algunos autores clásicos para los que la nación ha sido históricamente un artefacto cultural en manos de la clase burguesa (Anderson, 1993; Gellner, 1988), y parcialmente para otros, quienes, sin desconocer la injerencia de los sectores hegemónicos, reconocen la importancia de apuestas y apropiaciones populares (Hobsbawm, 1991).

En el mismo sentido de anotar el fracaso de nación, pero con otro matiz, Urrego (2004) afirma que fue inevitable el contraste del país con otras naciones de Occidente y en concreto con Francia, Inglaterra y Estados Unidos, con las cuales se midieron, en su momento, los impulsores del proyecto nacionalista en el país. Ello, según el autor, permite hablar del carácter inconcluso del Estado nacional, especialmente en el siglo XIX y principios del XX. Para Urrego, el discurso sobre la construcción de la nación fue tardío respecto a otros contextos y se tornó muy complejo y debilitado debido a varios factores: el demorado surgimiento de la clase obrera, una intelectualidad no formada en nuevas corrientes y el marginamiento de los partidos tradicionales en la polémica sobre el tema de la nacionalidad. Urrego dice que solo el mito de la Violencia ${ }^{3}$ de mediados del siglo XX logró generar imaginarios comunes que, aunque nefastos, permitieron la generación de referentes propios, aunque también este fenómeno dio vía a la legitimación de prácticas políticas excluyentes que parecieron clausurar la idea de un futuro compartido.

Urrego (1998) considera que Colombia carece de un mito fundador fuerte, al estilo de México, Perú o Estados Unidos, países que sí lo tienen. En este mismo sentido, afirma Bushnell (1996), es lugar común escuchar que Colombia carece de una verdadera identidad nacional, o de un espíritu nacionalista propio en comparación con sus vecinos latinoamericanos: "El nacionalismo a ultranza no es común en Colombia,

3 Período que abarca de 1946 a 1964 caracterizado por una intensa guerra sectaria, bipartidista, cuyas muertes oscilan entre 80.000 y 400.000 según la fuente (Safford y Palacios, 2002). 
y el carácter nacional, si se puede aseverar que tal cosa existe, es un agregado de rasgos a menudo contradictorios" (Bushnell, 1996, p. 17).

Urrego $(1998,2004)$ reitera que Colombia, al carecer de un relato fundacional que permita que los ciudadanos se consideren herederos de una tradición o miembros de una utopía, permite que la violencia y las reiteradas prácticas políticas excluyentes sean las que le den la marca de su identidad. En tal sentido, la realización de la modernidad del Estado nacional se mantuvo en el país como un asunto pendiente, "máxime cuando el proyecto neoliberal amenaza con romper el frágil tejido simbólico de la nación" (Urrego, 1998, p. 17). Países como México o Perú sí experimentaron la efervescencia de un nacionalismo que produjo íconos y mitos que aportaron a la identidad nacional. La popularización del recuerdo de los primeros habitantes de Tenochtitlán o de la península de Yucatán, y el fervor masivo a la virgen de Guadalupe, sellan un imaginario que activó sentidos a la mexicanidad. Caso parecido lo tuvo Perú con los incas, o los Estados Unidos con el destino manifiesto, cuyo mito de origen con contenido religioso concibió la colonización como expresión de la voluntad divina y como la ocasión para crear una tierra de libertad, oportunidad y trabajo. En Puerto Rico, a pesar de la escasa población indígena y su veloz aniquilación por parte de los españoles, la presencia taína ${ }^{4}$ es clave en la cultura nacional y el hecho de nombrar la isla como Borinquen y a los nacidos allí como boricuas relieva el vínculo con el pasado. Dice Urrego (2004) que la música, sobre todo los ritmos vernáculos como la plena y la bomba, expresaron el nexo con la cultura negra y fue usada en rechazo de los modelos anglosajones.

La idea del mito fundacional ${ }^{5}$, como prerrequisito para la edificación de la nación mexicana bajo el presupuesto de ubicar una entidad preexistente, milenaria, es criticada por Linares (2010). Este autor indica que la narración de la independencia de México (1821) en realidad buscaba inventar una identidad colectiva a partir de una apropiación selectiva del pasado de los pueblos que habitaron la región desde las necesidades, urgencias y problemas del presente: "Se apropió no solo en el sentido de tomar como propio lo ajeno, sino de inventar o construir un relato que permitiera nacionalizar la historia, legitimar sus nuevos gobiernos e impermeabilizar su proyecto de sociedad y nación" (Linares, 2010, p. 10). Al igual que la mayoría de naciones americanas,

$4 \quad$ Grupo étnico precolombino de la isla.

5 Se entiende por tal el relato o narración construido como arma historiográfica, cultural, educativa e ideológica, de lo que sería el prístino nacimiento de una sociedad (Linares, 2010). 
en México la independencia sirvió de caldo de cultivo para la creación de relatos canónicos sobre la nación, el pueblo y los héroes. Según este autor, lo que hizo el mito fundacional fue trazar una línea de continuidad entre pobladores originarios, la sociedad colonial y los criollos del siglo XIX, mito que en algunos contextos sobrevive hasta la actualidad.

En la línea de fechar el origen de la nación colombiana, María Elena Erazo (2008) considera que los inicios de la construcción de nación en el país se dieron a finales del siglo XIX, momento protocolizado con la Constitución de 1886, en el contexto de la Regeneración ${ }^{6}$, ya que por primera vez se puso en marcha una serie de procesos de cohesión, unificación, imposición y orden social propios de una nación verdadera, con el uso de dispositivos como la escuela, la lengua y la religión a nivel masivo.

Para Erazo este proceso se expresó de varias formas: primero, la consolidación del Ejército como institución organizada con personal profesional y asesoría internacional; segundo, la formalización del castellano, con el desconocimiento de otras lenguas aborígenes y el establecimiento de reglas, institutos y sistemas de exclusión lingüística; y tercero, la religión, que si bien era reconocida como mayoritaria desde antes de 1886, resurgió en un momento de crisis, pues reformas liberales anteriores intentaron quitarle el monopolio de la enseñanza a la Iglesia católica. Bajo el amparo de la Constitución de 1886 se firmó el concordato con el Vaticano y se volvió a dejar bajo la tutela religiosa la formación y la

facultad de imponer de manera unilateral textos de religión, filosofía y moral: el derecho de denunciar y hacer excluir a todo docente que pudiera aparecer como sospechoso de creencias religiosas o morales distintas de las que el Estado sancionaba como oficiales; y la interferencia de todo contenido literario o científico de la enseñanza (Silva, citado por Erazo, 2008, p. 44).

Según Erazo, el cuarto poder que contribuyó a la conformación de nación colombiana fue la escuela, con un plan de enseñanza unificado, de corte católico, industrial para la primaria y secundaria, y clásico para la universidad, punto que chocó con la escasa profesionalización docente, que para 1919 era apenas de 882 maestros, de los cuales

6 Período que va de 1878 a 1900 caracterizado por la hegemonía del Partido Conservador, aunque con la alianza de liberales. Se propuso la centralización del poder luego de una experiencia federalista y el uso del catolicismo como elemento de unificación ideológica bajo el lema "una nación, una raza, un Dios". En 1886 se promulgó una Constitución de talante conservador que perduró hasta 1991. 
solo 242 tenían estudios de pedagogía. El último bastión de la gesta constructora de nación fue la formalización de la historia como disciplina oficial, que se encargó, especialmente desde lo definido por la Academia Colombiana de Historia, de prescribir la educación patria mediante manuales y cartillas para impartir en las escuelas, y con la inculcación amplia de valores y símbolos particulares con los que los habitantes del país se debían identificar.

La autora insiste en que estos dispositivos creados por las élites en el poder desde finales del siglo XIX tuvieron la constante de desconocer, excluir y segregar otras expresiones culturales y otras cosmovisiones y que, por tanto, el tipo de nación que legaron homogeneizó y no aceptó la diferencia; además prohibió, censuró y eliminó sobre todo lo indígena, lo negro, lo campesino y lo regional.

Desde otro enfoque, Absalón Jiménez (2005) considera que el proceso de construcción del Estado nación se empezó a gestar antes de la Regeneración, incluso antes de 1810, y en él participaron de manera mutua las élites y los sectores subalternos, estos últimos sentaron las bases del movimiento independentista con la revuelta comunera de 1781. Jiménez le da protagonismo en la construcción de nación a los artesanos, los campesinos y posteriormente a los gaitanistas. Las élites lo hicieron con la Expedición Botánica de 1783, la adaptación de la Revolución francesa y el intercambio logrado por sectores económicos. "La construcción del Estado colombiano tiene que ver con la materialización de cierto tipo de identidad nacional que se consolidó primero en los escenarios locales y regionales" (Jiménez, 2005, p. 18), aunque debido a las guerras y a la fragmentación nacional tal referente nunca fue del todo claro. Jiménez se apoya en las ideas del historiador Marcos Palacios (2003), quien afirma que fue en el período de 1870 a 1956 que se consolidó en el país el proyecto de Estado nación, gracias a la entrada del café al mercado internacional, cuya distribución y comercialización las monopolizó una élite económica que creó gremios oligárquicos y formalizó la alianza entre el poder político y económico. Para Jiménez (2005), "en ese trecho el Estado colombiano fue un mero compromisario entre los intereses de los cafeteros, banqueros e importadores y los intereses, igualmente concentrados, de los industriales" (p. 15). El Estado no hizo realidad la sentencia weberiana sobre el monopolio de la fuerza en este período, más bien legitimó ejércitos regionales como expresión de intereses particulares, aspecto que trajo la privatización de la guerra misma, por tanto, pese a la unificación económica las fuerzas militares tampoco representaron un referente claro de construcción de identidad nacional. 
Desde otra perspectiva, Fernán González (2004a), menos preocupado por ubicar el exceso o la carencia de nación y más por situar la violencia como impronta identitaria, señala dos fenómenos históricos que se remontan al poblamiento del país desde tiempos coloniales y que son necesarios para entender el conflicto colombiano: la colonización campesina de zonas periféricas, producto de la sin salida a la reforma agraria y a la concentración de la propiedad rural, y en segundo lugar la construcción del Estado con presencia diferenciada en las regiones, según tiempo y lugar.

Para González, desde principios del siglo XVIII las zonas más aisladas de lo que sería después Colombia se fueron poblando con grupos marginales que generaron una convivencia propia, libre de la presencia del Estado, y allí donde este hizo presencia su control se ejerció a través de élites locales. Para dicho autor "la combinación de este poblamiento con esta dependencia de los poderes locales hizo muy conflictivos los procesos de integración de los territorios recién poblados al conjunto de la nación" (González, 2004a, p. 11). Las disputas entre liberales y conservadores a lo largo de los siglos XIX y XX giraron sobre el alcance de los procesos de modernización económica y social y sobre el papel de la Iglesia católica, además coparon la agenda de la vida política del país. Este enfrentamiento sirvió de canal de expresión de problemas sociales y económicos como problemas de tierras, pugnas entre regiones, líos de territorios, conflictos raciales o enfrentamientos entre familias.

Al lado de las instituciones políticas de carácter formal operaban los partidos tradicionales como federaciones locales y regionales de poder de tinte clientelista, que a su vez hacían de intermediarios entre las autoridades centrales y regionales. Por ello los fenómenos violentos eran tan diferenciados, como lo fue la consolidación de las instituciones estatales en los diversos contextos locales. Dice González que la violencia fue diferenciada, dependiendo de si fueron o no regiones integradas, con alta o baja influencia de los poderes locales, con mecanismos tradicionales fuertes o débiles de regulación social, y de las luchas por el control territorial. Y dado el nivel político de la confrontación se puede colegir que también lo fue el proceso histórico de construcción de nación, es decir, la presencia del Estado para hacer nación fue diferencial, fragmentada y desigual, acorde con las condiciones de cada región del territorio nacional.

González (2004a) considera que las tres principales guerras del siglo XIX en Colombia produjeron importantes elementos de identificación nacional, pues la marca que tuvo el vínculo de los colombianos a los 
partidos políticos queda definida a partir de estos sucesos. Paradójicamente estas guerras generaron mayor integración al territorio nacional, mayor relación entre los grupos de poder de las diversas regiones y localidades, algún tipo de integración de grupos subordinados mediante el reclutamiento a la milicia e importantes mecanismos de adscripción clientelista y adhesiones a la defensa de las localidades y las regiones. Pero no como comunidades imaginadas de conciudadanos, al decir de Anderson (1993), sino como confederaciones de redes particulares de poder, "de comunidades escindidas de copartidarios, de una ciudadanía escindida por la pertenencia a los partidos tradicionales, de identidades fragmentadas y mutuamente excluyentes, construidas paulatinamente por medio de conflictos armados de carácter interno" (González, 2004a, p. 46). Para González la guerra de los Supremos (1839-1841) dejó como resultado la constitución de los partidos como federaciones suprarregionales de redes locales de poder que sirvieron de intermediarias entre las regiones y el Estado central; por su parte, las guerras de 1851 y 1854 expresaron definiciones más ideológicas sobre el papel de la Iglesia en la sociedad, la ampliación de la ciudadanía y los límites de la movilización popular.

La identidad nacional, en el siglo XIX, fue edificada en medio de los avatares propios de la política nacional, en particular bajo la égida del desarrollo y fortalecimiento de unos partidos políticos, el Liberal y el Conservador, los que a falta de referentes nacionales, aglutinantes u homogeneizadores, proporcionaron más bien las herramientas para una identidad sectaria, partidista, regionalista y clientelar. Para González la vinculación con la práctica del catolicismo fue el aspecto que recorrió las ideologías en común.

El autor particulariza en su análisis para caracterizar el conflicto en el siglo XX en la época de la Violencia, en el Ilamado Frente Nacional (1958-1974), y en la penetración del narcotráfico y sugiere para la actualidad una geografía de la violencia en la que existe una dinámica nacional de lucha por corredores estratégicos para sostener la comercialización de drogas ilegales que garantizan el poder económico y un margen de maniobrabilidad militar. También postula una dinámica regional de enfrentamiento por el control de recursos y una dinámica subregional por el control de pequeños territorios. Según dicho autor, la diferenciación y fragmentación territorial perviven y se constituyen en el referente de análisis a tener en cuenta a la hora de hablar de identidad nacional en el siglo XXI. 
Tal fragmentación se refuerza, según María Teresa Uribe (2001), porque Colombia ha presentado un curioso dilema frente al contexto de los países latinoamericanos, pues su régimen político ha sido más o menos estable y ofrecido una continuidad institucional y parlamentaria sin mayores contratiempos desde su inauguración como república. Sin embargo, tal ordenamiento jurídico y constitucional "coexiste, sin mayores tensiones, con una altísima turbulencia social y una violencia endémica que como hilo grueso atraviesa la historia del país" (Uribe, 2001, p. 196). Por ello, esta autora sugiere un acercamiento metodológico centrado en la historia y la cultura para identificar la forma como se desarrollaron y mezclaron las instituciones liberales modernas centradas en el ciudadano, la nación y la representación, con las diferentes dinámicas sociales, étnicas, morales y comunitarias históricamente constituidas. Tal postura posibilita la identificación de diversas formaciones sociales y el rescate de la especificidad en las articulaciones entre Estado y sociedad civil, lo público y lo privado, el ciudadano y la nación, la guerra y la política, hecho que a su vez remite a hablar de órdenes sociales ${ }^{7}$ que no necesariamente coinciden con los normativos y constitucionales, sino que más bien conforman constelaciones de sentido que orientan la acción social, las prácticas, las creencias y los valores que también se expresan en la esfera de la acción política.

Esta tensión entre lo político y lo social permite entender la fuerza que tuvo en la conformación de la identidad nacional el aspecto regional, y explica a su vez la debilidad de los discursos nacionalizantes que enarboló el Estado central, con mensajes distantes y abstractos que propendían por la adhesión a una iconografía ajena a las rutinas de los pobladores.

Esta tesis sobre la presencia diferenciada y fragmentada del Estado es particularmente relevante para el alcance de la presente investigación, en tanto permite entender la forma como en la actualidad es posible detectar la presencia de hibridaciones, mezclas o mestizajes, respecto a proyectos de nación en los imaginarios de los ciudadanos, al decir de Uribe (2001). El Estado colombiano, legendariamente incapaz de garantizar la legitimidad en el territorio nacional, no ha podido "instaurar un orden político que logre cohesionar las diversidades socioculturales, las fragmentaciones económicas, las divergencias políticas, o que

7 "Los órdenes [...] aluden [...] a sistemas de reglas, de normas, de pautas de acción y de comportamiento institucional o social, sustentados en valores y en una definición de jerarquías que establecen el marco de las relaciones entre los sujetos -individuales y colectivos-y entre éstos con la autoridad, el poder y el aparato público" (Uribe, 2001, p. 197). 
si no lo logra, al menos las reconozca para integrarlas en un modelo democrático realmente representativo de esas múltiples diferencias" (Uribe, 2001, p. 24) ${ }^{8}$. Destiempos y desencuentros, según la socióloga, han sido características permanentes que han generado una profunda ruptura entre el pueblo y las élites. La ausencia del Estado en vastas zonas, no solo alude a la carencia de legitimidad pues buena parte de los ciudadanos no han sido nunca sujetos de derechos, sino que, o mejor, gracias a ello, han perfilado su identidad a partir de otros componentes e insumos culturales.

Durante mucho tiempo ser colombiano pasó inevitablemente por el vínculo con los partidos tradicionales, con sus secuelas de sectarismo y violencia:

Ser liberal o conservador, pertenecer a una colectividad que iba más allá de los altos campanarios parroquiales, fue la única manera de saber que se pertenecía a una entidad mayor, que se era parte de algo que se llamaba Colombia, que no existía como espacio económicamente integrado ni como espacio cultural o éticamente cohesionado, pero que la vía de la política estaba formando (Uribe, 2001, p. 27).

Poderes tradicionales, económicos, políticos, sociales, mafiosos y de otra índole, al suplantar en unas regiones o disputarle en otras al Estado el monopolio del poder, han contribuido a delinear variadas formas de cultura política que también se traducen en la subjetividad y en identificación con la nación propia de muchos colombianos.

Esta situación y la implantación de un modelo económico excluyente y desigual ha provocado la descomposición del tejido social y la multipolaridad del poder, según Uribe, lo que también ha conducido a la merma de lo público y al atrincheramiento de los pobladores en la esfera privada, hecho que coadyuva a la generación de identidades nacionales desvinculadas de proyectos sociales y políticos, y más enganchadas con lo mediático, lo espectacular, lo efímero. Por ello la legitimidad tiene mucho que ver con la identidad nacional, pues su exagerada heterogeneidad puede expresar la incapacidad para generar consensos. En forma lapidaria María Teresa Uribe considera:

8 "Por legitimidad entiendo el hecho de que un orden político es merecedor de reconocimiento. La pretensión de legitimidad hace referencia a la garantía —en el plano de la integración social — de una identidad social determinada por vías normativas: las legitimaciones sirven para hacer efectiva esa pretensión, esto es, para mostrar cómo y por qué las instituciones existentes —o las recomendadas- son adecuadas para emplear el poder político en forma tal que lleguen a realizarse los valores constitutivos de la identidad en la sociedad" (Habermas, citado por Uribe, 2001, p. 40). 


\begin{abstract}
El Estado, la ley y las instituciones no han sido referentes de identidad y, por el contrario, una historia ancestral de exclusión ha permitido la formación de órdenes normativos y sistemas de valores paralelos y a veces antagónicos a los que rigen institucionalmente, continuando, aunque de otra manera, el proceso de fragmentación territorial (Uribe, 2001, p. 50).
\end{abstract}

Julio Arias (2005), al analizar el papel de ciertos intelectuales en la conformación de la nación y la identidad nacional en el siglo XIX, proporciona otros ingredientes a su construcción histórica, además de las presentadas hasta este punto. Indica que pese a la aparente distancia con el pasado español, intelectuales cultores de los sentidos de la identidad nacional se preocuparon por mantener la tradición hispánica como estrategia de diferenciación social: "La nación resultaba fundada así en una tensión entre lo propio y lo ajeno. Lo nuestro, como individualidad diferenciable que emerge de la crítica y la distancia frente a lo otro, tenía como origen el otro español" (Arias, 2005, p. 13). Tensión que se creía superada con la imagen de que lo español era un pasado que nutría, un suelo del cual nacía el carácter único nacional.

Para el citado autor, según las élites, la cortesía, la gramática, la lengua, las bellas artes y las tradiciones culturales formaban parte del ideal a perseguir en la configuración de la identidad nacional de aquella época. En el caso de la lengua como elemento de unidad cultural nacional, no solo se tornó estrategia de distinción y refinamiento, sino que la gramática española y la enseñanza del español fueron claves para el establecimiento de la nación, pues "la unificación lingüística aparecía como una obligación para la nación" (p. 15), de manera que el buen juicio, el sentido común y los criterios de belleza pasaban por el uso correcto y refinado del idioma. Se entienden así las palabras de Miguel Antonio Caro: "si la unidad de lenguaje ha sido siempre una bendición de Dios, un principio de fuerza incontestable, la multiplicación de dialectos ha sido, a su vez, desde la ruina de Babel, castigo providencial, anuncio de debilidad y presagio de destrucción de naciones enteras" (citado por Arias, 2005, p. 15), palabras que ubican los esfuerzos de las élites de finales del siglo XIX y principios del XX por homogeneizar la idea de identidad nacional en torno a determinado uso de la lengua y a una mirada aristocrática de la cultura. Con Caro la simbiosis del político y el lingüista pusieron en evidencia el uso del lenguaje como estrategia de distinción, exclusión y poder, ya que desde su posición la representación que construyeron del mundo contribuyó a perpetuar la realidad social, con importantes repercusiones sociales y políticas. En este sentido, para Bourdieu (2003), entre más capital simbólico y 
político acumulado, entre mayor vinculación con el Estado ${ }^{9}$, mayor capacidad de incidencia se tiene. El intelectual ligado al Estado, él mismo emergiendo gracias a redes, grupos, personas y fuerzas sociales, modifica con su producción "la representación del mundo social y, al mismo tiempo, el mundo social, al menos en la medida en que ella hace posibles prácticas conformes a esta representación transformada" (p. 5). Las élites, desde el Estado, al describir una supuesta identidad nacional, prescribieron una determinada manera de ser y hablar. Para Deas (2006), "la gramática, el dominio de la lengua, era componente muy importante de la hegemonía conservadora que duró entre 1885 y 1930, y cuyos efectos persistieron hasta tiempos muy recientes" (p. 30).

De acuerdo con el mismo criterio anterior, la comunidad nacional también debió ser pensada como comunidad religiosa, en el que el catolicismo no solo fue tratado como la religión oficial sino como parte del carácter del pueblo nacional. Las tensiones entre liberales y conservadores eran más por la injerencia de la Iglesia en asuntos públicos que por el cuestionamiento a la moral religiosa, según Arias (2005). Los proyectos unificadores del siglo XIX en torno a una religión nacional tuvieron sentido como factor de cohesión en medio de un país fragmentado, posibilitando "la contención de distintas poblaciones bajo unos mismos patrones, manteniendo e incluso consolidando un orden jerárquico" (Arias, 2005, p. 17).

Los curas, agentes civilizadores de entonces, que hicieron presencia en las parroquias de los pueblos y en las escuelas públicas y privadas a lo largo y ancho del país, desempeñaron una función indiscutible en la masificación de un proyecto en el que valores como la laboriosidad, la vida familiar, la rectitud, la honestidad, la serenidad y el patriotismo se asociaron y asumieron como principios evangélicos y nacionales. Sobre esta misma idea, Palacios (2003) destaca el papel de la Iglesia como configuradora de la identidad nacional al reemplazar al Estado en sus funciones educativas, ya que no solo gozó de privilegios legales, sino que tuvo mucha más estabilidad a lo largo del tiempo que el poder civil; para este autor,

dicha estabilidad dio a la Iglesia una gran ventaja sobre el Estado. A diferencia del faccioso país político, la jerarquía, con algunos

9 Respecto a la capacidad de imponer realidades desde el Estado por medio del discurso, dice Bourdieu (1993) que "la doxa es un punto de vista particular, el punto de vista de los dominantes, que se presenta y se impone como punto de vista universal; el punto de vista de los que dominan dominando al Estado y que han constituido su punto de vista como punto de vista universal al hacer al Estado" (p. 11). 
paréntesis como el de $1929^{10}$, pareció hablar con una sola voz, reforzando con ellos su autoridad, al menos desde la Regeneración hasta los inicios del Frente Nacional (Palacios, 2003, p. 16).

De igual modo, surgieron tipos ideales de identidades regionales como una manera de develar los desiguales vínculos económicos, políticos y simbólicos entre las regiones y el Estado central. El modelo antioqueño ligado a la belleza, el trabajo, la religiosidad, se afianzó como proyecto regional fundamentalmente después de la segunda mitad del siglo XIX, con pretensiones, incluso, de Estado independiente. En medio de crisis políticas y económicas el imaginario de un pueblo antioqueño homogéneo tomaba fuerza en medio de una enorme heterogeneidad nacional; además, "la insistencia en valores compartidos como la laboriosidad, el origen pobre, el ascenso por medio del trabajo, lo campesino, la frugalidad, la austeridad y la sencillez, era una forma de contraponerse a la élite santafereña" (Arias, 2005, p. 115). Más que la visión de colonos, fue la de comerciantes andariegos la que primó en torno a lo antioqueño, y después la minería, y gracias a sus réditos luego el comercio fue la actividad privilegiada por muchos habitantes de esta región del país.

Por su parte, la formación del Estado de Santander en 1857 acentuó un tipo de persona característica de esta región. Ejemplo de ideas republicanas sobre el intercambio mercantil, la propiedad y la política, así como de moralidad y disposición para el trabajo, esta región contenía un supuesto prototipo que la diferenciaba del semifeudal y estacionario altiplano y de los salvajes y amorales de las tierras calientes de los valles entre las cordilleras. La proyección de estos ideales se hizo mediante la racialización de su población con valores asociados a la fisonomía blanca: mestizos blanqueados, inteligentes, vigorosos, activos, sanos y de buenas costumbres. No obstante, para Arias los santandereanos fueron reconocidos, hacia finales del siglo, exclusivamente como buenos agricultores y su centralidad en el imaginario de nación ya no era evidente ante la importancia del altiplano cundiboyacense.

Finalmente, la población Ilanera como tipo regional fue definida a partir de unas actividades particulares, así como los bogas ${ }^{11}$ del Magdalena y los cosecheros de la zona andina. El imaginario sobre el Ilanero

10 Lapso correspondiente a la llamada república liberal (1929-1946), de cuatro períodos presidenciales del partido político de ese nombre y caracterizado por la centralización política, el ajuste fiscal, el librecambio en el comercio internacional y serios intentos de secularización del país luego de una larga hegemonía conservadora. 
estuvo marcado por la idea de un medio físico que determinaba a un tipo humano. La sabana, los ríos, la soledad, los desiertos, la naturaleza salvaje y la ganadería configuran los modelos de lo que era esta región y sus pobladores. La participación en las milicias Ilaneras en la guerra de independencia, igual que sucedió con la revolución comunera para los santandereanos, soportó la imagen de un ser belicoso y hábil para la guerra. Por su parte, lo tolimense, lo santafereño, lo payanés y lo costeño fueron arquetipos construidos de identidad regional, diferencias aceptables en el concierto nacional, etiquetas clasificatorias puestas por las élites para hacerse a la dominación simbólica de la nación, identidades regionales que buscaban perfilar maneras de ser y pensar en medio de una nación desigual y quebrada.

El historiador Jorge Orlando Melo $(1989,2006)$ ha dedicado algunos de sus escritos a problematizar el tema de la identidad nacional en el país. Reconoce lo poco que ha sido trabajada y considera que el concepto es ambiguo y problemático, que es preferible abandonar su uso y acceder a nuevas formas para definir la situación cultural del país. Para este autor, el término, en un sentido político, lo puso de moda en la década de los ochenta del pasado siglo el expresidente Belisario Betancur, quien mencionó una y otra vez la identidad colombiana y defendió la unidad cultural latinoamericana (Melo, 2006).

Para el historiador, y abordada sobre todo por ensayistas, periodistas y literatos, la identidad nacional en realidad ha ensalzado las diferencias regionales en procura de responder a una pregunta por lo nacional. Los primeros esbozos de conciencia nacional hay que ubicarlos en los conflictos de las élites ilustradas locales por reformar el sistema educativo en la segunda mitad del siglo XVIII. Allí la palabra 'patria' estuvo asociada a lo americano, en contraposición a España.

La idea de nación como un concepto delimitador probablemente surge entre la élite que va a los colegios, en particular santafereños. Tal delimitación se apoya en una contraposición inicial entre criollos y españoles, que aparece alrededor del tema de los empleos: siendo todos tan blancos como los españoles, los criollos son definidos por el sistema como miembros de una comunidad diferente por la imposibilidad de ocupar los mismos cargos que los españoles (Melo, 1989, s. p.).

En este conflicto por lograr reconocimiento, los criollos reivindicaron a la Nueva Granada como un lugar donde ellos tenían los mismos de- 
rechos que los españoles. La idea de patria se definió como esa nueva comunidad de excluidos en ascenso, los criollos.

El contexto de la independencia permitió identificar en la figura de la nación, independientemente de la influencia de la lengua, la religión, las etnias y las diferencias culturales, una débil unidad en función de la construcción del Estado, en el que podía ejercerse un dominio político. Para Melo, lo que definió el orden de lo nacional fue la prolongación de la división administrativa colonial, que se extendió en las nacientes instituciones del Estado, prueba de ello fue que "en ningún caso fue posible mantener unidas entidades que administrativamente estuvieron desunidas durante la época colonial" (Melo, 1989, s. p). Durante mucho tiempo la identificación personal de las mayorías siguió siendo local y crecientemente regional debido a conflictos administrativos, falta de control de recursos económicos, incomunicación y guerras civiles.

El fracaso del proyecto de la Regeneración contribuyó a crear un inicial imaginario de identidad nacional al imponer un significado centralizador ligado a la hispanidad, el idioma y la religión. Blanquear las razas y dejarse civilizar por el centro del país fueron las demandas para unificar la nación. Esta empresa no fue exitosa, la rígida centralización no pudo extenderse al mundo de la cultura ni de la educación y más bien provocó la reafirmación de los estereotipos regionales, según Melo. Caso especial lo fue Antioquia, que desde antes enarboló su propio himno contra el nacional, emprendió la lucha por la descentralización y afianzó un discurso de valores propios, distintos a los de la capital. Estos esfuerzos unificadores provocaron el refuerzo de un actor político con ingente protagonismo, que en muchos sentidos reemplazó al Estado: los partidos políticos. Melo coincide con Uribe (2001) y González (2004b), en que los partidos se convirtieron en la mayoría de casos en el único referente nacional que trascendió la esfera de lo local, "de manera tal que la comunidad imaginada se imbricaba con el partido y se confundía con él" (Uribe, 2001, p. 244). Atizados por la violencia, los partidos se convirtieron en referentes de identidad colectiva, vínculos de pertenencia social, comunidad de sangre y atributos imborrables de familia. Ello explica que en el país durante mucho tiempo, más que la adscripción a la nación como territorio, predominara el vínculo con el color partidista y la radical oposición al otro grupo, "de esta manera la identidad nacional fue construida sobre referentes bélicos y escindida en dos mitades" (Uribe, 2001, p. 244). 
En los inicios del siglo XX, en pleno auge urbanizador y económico, Melo (1989) destaca la forma como la élite política vuelve a ver en el pueblo una amenaza y un obstáculo para el progreso ${ }^{12}$. Desde mucho antes, el indio y el negro fueron obligados a asumir que "sólo negando su identidad étnica y adoptando la del dominador, civilizándose o blanqueándose, era posible llegar a formar parte del pueblo nación" (Uribe, 2006, p. 51), polémica que llegó al Congreso en 1922, el cual estableció una ley de inmigración para favorecer la mezcla de razas pese a la oposición de sectores sociales. Lugar especial merece en este período el papel asignado a la escuela, a la que se encargó de promover el sentimiento hacia la nación mediante el culto a los héroes, la memoria gloriosa de las luchas de independencia, las efemérides patrias y los honores a la bandera, el himno y el escudo.

Además, hacia los años cuarenta y cincuenta aparecieron editoriales nacionales que intentaron romper las tradiciones narrativas regionales aprovechando la integración territorial lograda por el transporte. También fue clave la masificación de la radio y más adelante de la televisión, que gradualmente lograron integrar una geografía regional antes desconectada entre sí (Melo, 1989).

Según Melo, si la nación se realiza históricamente a través de la modernidad y la idea de nación implica que los sujetos dejen de considerar sus regiones como base territorial para sus acciones, va a ser la época de la Violencia, a partir de 1948, la que permite construir un relato nacional en Colombia en varios sentidos: primero, porque fue un acontecimiento que golpeó la mayoría de las zonas del país, a diferencia de enfrentamientos regionales y aislados que la precedieron; segundo, porque implicó una intervención estratégica del Estado en zonas donde se concentraban los recursos económicos y políticos; tercero, porque este acontecimiento ameritó un reconocimiento internacional en el que Colombia fue objeto de interés e intervención, y cuarto, fue el epítome del enfrentamiento partidista y de la posterior violencia guerrillera. En esta misma línea, Patiño (2005) considera que la Violencia "se constituyó en punto de partida para la formación de una identidad nacional en Colombia" (p. 1110), porque se convirtió en un relato que

12 Laureano Gómez dio su versión en 1928: el colombiano, por mestizo "no constituye un elemento utilizable para la unidad política y económica de América Latina: conserva demasiado los defectos indígenas: es falso, servil, abandonado y repugna todo esfuerzo y trabajo. Solo en cruces sucesivos de estos mestizos primarios con europeos se manifiesta la fuerza de caracteres adquirida por el blanco [...] El elemento negro constituye una tara: en los países de donde él ha desaparecido, como en la Argentina, Chile y Uruguay, se ha podido establecer una organización económica y política con sólidas bases de estabilidad" (citado por Melo, 1989, s. p.). 
justificó la ruptura del regionalismo con la conciencia política de la nación; porque desató e hizo visibles otras violencias de orden antiestatal, estatal y paraestatal (narradas por la literatura, estudiadas por los violentólogos y espectacularizada por los medios, especialmente la televisión); y porque generó un estereotipo de nación a partir de los estudios de intelectuales y académicos. Esta producción y "toda clase de discursos y conjeturas han inventado el rostro y el comportamiento de una sociedad que existe gracias a que se la nombra en su forma contemporánea: en el nombre de la violencia" (Patiño, 2005, p. 1112). La difusión intelectual y otros factores contribuyeron a hacer de la violencia de la mitad del siglo XX en el país un acontecimiento trascendental que configuró los trazos reconocibles de una comunidad imaginada (Anderson, 1993).

Según Patiño, se impuso una imagen simbólica del colombiano y del pueblo; visto antes como redimible, se da ahora con una capacidad de crueldad ilimitada. Por supuesto, vuelven a aparecer esfuerzos por ligar violencia y carácter, violencia y cultura. Paradójicamente, en este trasfondo se puede empezar a hablar de una identidad nacional, pues

quizás el mayor impacto de la violencia fue que, como toda gran catástrofe colectiva, desempeñó un papel unificador, sugirió nuevas percepciones de lo colombiano y nuevas tramas de solidaridad y oposición. Por otro lado, la violencia coincidió con el comienzo de un período que, de 1950 a hoy, es de una acelerada modernización cultural, ahora sí claramente homogeneizadora. La escuela, la radio, luego la televisión, la prensa nacional, la migración acelerada, el estudio y el trabajo fuera de la región de origen, las empresas nacionales, los consumos y la publicidad, todo va creando por primera vez una unidad vivida y simbólica colombiana para toda la población, no sólo para sectores más o menos elitistas (Melo, 1989, s. p.).

Varios cientistas sociales coinciden en señalar que la guerra y la violencia sucedieron fundamentalmente por la ausencia de soberanía estatal en territorios en los que varios agentes disputaron con las armas el dominio de estos, "o de resistir, también con las armas, sus intentos de control-dominación, manifestando de esta manera que no se acepta otro poder que el propio" (Uribe, 2001, p. 246). En palabras de Patiño (2005), la guerra y la violencia, previas a 1948, en lo político y en lo social, se interpretaban como un derecho de los habitantes de cada región cada vez que se encontraban en desacuerdo con el Estado, así "comenzó a considerarse y ejercerse la violencia como un arma política" (p. 1107). De manera que el orden institucional no era el orden 
de la nación, sino que era uno que se disputaba con otros la soberanía interna. En este pasado de confrontaciones bélicas, lealtades personales y seguridades privadas, resultaba débil la conciencia de nacionalidad, así como la integración política y simbólica del pueblo al Estado nación ${ }^{13}$.

Finalmente, para Melo (1989), estos conflictos se vieron incrementados con la no presencia de proyectos nacionalistas por parte de las élites o de grupos contrahegemónicos. Este vacío ocasionó una identidad nacional de baja intensidad ${ }^{14}$, lo cual explica que sea difícil encontrar en la actualidad elementos identitarios que distingan a Colombia de otras naciones, símbolos o rituales que aglutinen a la población. Hoy, continúa el autor, la identidad pareciera estar dominada por el espectáculo, por el interés propagandístico y comercial. "Los estereotipos que codifican las formas de ser, los valores y aspiraciones, los rasgos supuestos de los colombianos constituyen una trama múltiple en la que coexisten definiciones raciales, regionales, clasistas y nacionales" (Melo, 1989, s. p.). En concreto, continúa afirmando Melo, Ilama la atención que las confrontaciones armadas que rompen el país, no suceden por oposiciones abiertas de identidades subalternas o en disputa, o proyectos de nación contrapuestos. De hecho, la cuestión nacional está prácticamente ausente en las agendas de negociación de los diferentes grupos en conflicto, "cuyas propuestas apuntan más a proyectos de Estado y de sistema económico que a los asuntos de la cultura, y la integración del pueblo de la Nación o las identidades y los sentidos de pertenencia de los colombianos" (Uribe, 2006, p. 266).

Con relación a la configuración de elementos culturales de identidad nacional en el siglo XX, Animaría González (2009) realizó una investigación para analizar la forma en que siete décadas de vida del Museo del Oro contribuyeron a generar un sentido de identidad nacional. En ella considera que es imposible separar la identidad nacional de la construcción de la nación y de la memoria; en particular, afirma que fueron los cambios de la creación de la nación los que exaltaron la identidad, y que en una nación débil,

13 Complementa Patiño (2005) que solo hasta finales del siglo XIX se logró fabricar e imponer una moneda única, por encima de los intereses y prácticas regionales: "Durante la mayor parte del siglo se comerció con monedas regionales o con las emitidas por bancos privados, sobre todo después de la década de 1870" (p. 1108).

14 El politólogo Guillermo O’Donnell (1993) acuñó el término ciudadanía de baja intensidad para referirse a la creciente pérdida de derechos sociales vividos en América Latina, especialmente a partir de las dictaduras militares y los gobiernos autoritarios en la región, en la década de los setenta. 
relatos como los del Museo del Oro, al igual que lo hace la radio o la prensa, se tornan muy relevantes, ya que con ellos la nación colombiana encuentra puntos de cohesión y lugares de encuentro que no son siempre fáciles de hallar en las circunstancias particulares que ha vivido y sigue viviendo el país" (González, 2009, p. 24).

Para la autora, al igual que en muchos otros países, en Colombia los museos fueron espacios de expresión de un ideal nacionalista que encontraron en el mundo indígena un mito fundador de nación. Tal tesis parecería contradecir lo planteado por Urrego (2001), en el sentido de no necesitarse un mito uniforme, hegemónico, para lograr una construcción simbólica referida a elementos vernáculos.

Según González, en una confusión con las aparentes intenciones de las políticas culturales y en un claro desconocimiento del carácter elitista que representa la asistencia a los museos en el país, la cultura ha sido históricamente un camino hacia la reconciliación y a la identidad nacional, una necesidad fundamentada en la participación y la diferencia.

Para Martín-Barbero (2002), el país no ha tenido un relato nacional que posibilite a los colombianos de todas las clases y razas ubicar sus experiencias cotidianas en una mínima trama compartida de duelos y logros, "Un relato que deje colocar las violencias en la subhistoria de las catástrofes naturales, la de los cataclismos, o los puros revanchismos de facciones movidas por intereses irreconciliables, y empiece a tejer una memoria común" (p. 17). Para este autor la imposibilidad de tener un relato de nación tuvo varios capítulos, uno de los más destacados es el histórico desconocimiento del pueblo por las élites del poder; la exclusión de las regiones por parte del centro del país, la ausencia de migración extranjera, la incapacidad de los partidos políticos para construir un espacio público y la fuerza de las domésticas redes del narcotráfico, fueron la forma de poner a Colombia en la escena mundial.

Para salir del atolladero, sugiere Martín-Barbero, hay que crear un nuevo imaginario de nación, mucho menos relacionado con mismidades y esencias y más con narraciones y relatos, lo cual significa que "para ser reconocidos necesitamos contar nuestro relato, pues no existe identidad sin narración ya que ésta no es solo expresiva sino constitutiva de lo que somos" (Martín-Barbero, 2002, p. 23). Identidades tejidas de diversidad de códigos, lenguajes, escrituras y medios, que si bien son hegemonizadas y rentabilizadas por las lógicas del mercado, abren grandes posibilidades de subvertir esas mismas lógicas desde las dinámicas del arte y las contradicciones de los espacios intermedios, en 
que pueden emerger nuevos tejidos sociales, nuevos espacios públicos, un nuevo rostro de sociedad.

Sobre el papel de los intelectuales, estudios de otros países de América Latina (Funes, 2006) aportan una importante revisión hecha sobre la década de 1920 en la obra de varios personajes del continente, en la que se tensiona el papel de la lengua y la literatura nacional, de lo culto y lo popular, de lo oral y lo escrito como elementos definidores de lo nacional. En aquella década el problema nacional se instaló en el centro de la reflexión intelectual de varios países, "salvar la nación" se erigió como una tarea que estos tomaron como parte de sus prioridades. La fundación de la Alianza Popular Revolucionario Americana (APRA), de la Liga Antimperialista de las Américas y la revista El Libertador en México, de la Unión Latinoamericana y la revista Renovación en Argentina, de la revista costarricense Repertorio Latinoamericano, la invención del neocriollo ${ }^{15}$ por parte del pintor Xul Solar o de la ortografía indoamericana del vanguardista peruano Francisqo Chiqiwanka, son algunos ejemplos del carácter contestatario e híbrido que caracterizaron algunos movimientos nacionalistas preocupados por el asunto de la integración latinoamericana ${ }^{16}$ y por una mirada nueva de lo nacional.

En la década de los veinte la nación fue un aspecto que se ubicó en el centro del repertorio intelectual y en este contexto histórico se acudió al pasado remoto para justificar linajes y ascendencias, dice Funes (2006). Para aquellos individuos, los orígenes de la nación se remontaban a las culturas indígenas, a pasados remotos, a raigambres densas, a antiguas imágenes en las cuales anclar nuevas intenciones. Pero "la nación también se ensancha en densidad social: negros, indios, campesinos, rurales, son incorporados a la discusión de lo nacional en provocativo gesto de ruptura con respecto a la exclusión social, política, económica y étnica del orden oligárquico" (Funes, 2006, pp. 18-19), es decir, en la visión de pensadores de la década de los veinte el espacio nacional tenía que contar con nuevos protagonistas relegados hasta entonces. Pese a estas intenciones, afirma la autora, estas naciones nunca fueron indígenas ni campesinas, pues la idea de un mestizaje espiritual se impuso por encima de desniveles étnicos, clasistas o culturales, de manera que "todo tiende a destilar en un precipitado que impele a borrar las diferencias, no tanto así las desigualdades, en todos los casos a galvanizar imaginarios comunes y 'comunidades imaginadas'" (p.

15 Lengua mestiza entre el español y el portugués.

16 Funes (2006) comenta que en 1927 el Senado mexicano aprobó un proyecto de ley para invitar a los gobiernos de la región a establecer una ciudadanía latinoamericana, con los mismos derechos de los países de origen. 
406). Colombia representa una excepción frente a esta tendencia; de hecho, cuesta mucho encontrar a un intelectual de la época que tenga una opinión en fuerte oposición a lo que pensaban los defensores de la eugenesia y el dominio racial en las primeras décadas del siglo XX en el país.

Fruto de la crisis que produjo la Primera Guerra Mundial y las críticas al orden oligárquico que predominaron en el siglo XIX, sectores intelectuales se propusieron como tarea la revisión del antiguo orden y la proyección de establecer uno nuevo. Para Funes el siglo XIX, en cuanto a construcción de nación, estuvo marcado por criterios liberales y universalistas cuyo centro fue la definición de la ciudadanía, la tradición positivista y la morfología racial, criterios que serán revisados en la segunda década del siglo $X X$ a partir de una mirada distinta sobre el pasado, el reconocimiento de antecedentes y precedencias, de ideales románticos y de nueva densidad social al reconsiderar al otro, antes excluido. La concepción de progreso, de racionalidad, de evolucionismo social rectilíneo y homogéneo, bajo la tutela del pensamiento europeo, también fue criticada. Para la época se reeditó la posibilidad de un pensamiento latinoamericano original.

Es ilustrativo el caso de México luego de la revolución campesina de 1910, que dio origen a la reconstrucción del Estado y a la redefinición de la nación, que impuso un discurso nacionalista y de reivindicación del sustrato indígena y campesino, y que además contó con el ingente protagonismo de la intelectualidad de esta nación. Durante el período de estudio, en Perú, en cambio, los pensadores excluidos del ámbito político escribieron y produjeron por fuera del Estado. Haya de la Torre, Mariátegui, Vasconcelos, Belaúnde y Leguía son algunos hombres que retoma Funes para ejemplificar la cuestión del indigenismo, el socialismo y el socialcristianismo peruano. En el caso de Argentina resalta la producción desde la Generación del Centenario, en la que representaciones culturales de europeísmo, blanquitud y lo urbano como valores dominantes ceden su lugar a consideraciones identitarias de orden más nacional; este país transitó por la experiencia de una democracia ampliada que desplazó del poder a las oligarquías y amplió las bases representativas del Estado y la nación. Para Funes (2006),

al esbozar las tradiciones interpretativas del concepto nación en la modernidad, se señalaron dos territorios hermenéuticos, a veces ambivalentes, a veces forzadamente complementarios. Con sus matices, para algunos la nación es una entidad acabada, un "dato" con atributos inmodificables y un "genio" idiosincrático que a lo sumo hay que "despertar" o fortalecer. Para otros, es una 
construcción pendiente, un devenir que no despojado de caracteres identitarios, depende en gran medida de voluntades contractuales, activas y protagónicas. En ambos casos, los intelectuales de los años veinte apelaron a la historia y a unos precursores $y$ tradiciones que construyeron con el objetivo de "demostrar", la existencia "ontológica" de esa nación que había que "restaurar", para advertir las insuficiencias y frustraciones de representaciones nacionales demasiado estrechas para dar cuenta de las complejidades sociales (p. 80).

Otro imaginario intelectual fuerte para la década de 1920 en México, Perú y Argentina tuvo que ver con la definición y el auge del antiimperialismo, que si bien tenía antecedentes se constituyó en un objetivo teórico y político en medio de la expansión estadounidense en la región. Este pensamiento marcó una pauta a escala regional y señaló destinos y estrategias comunes para el continente. Autonomía y soberanía se cargan de sentido respecto a una potencia imperial y temas como patriotismo, nacionalismo y nación son analizados a partir de la dependencia económica y política, en clara distancia con las anteriores generaciones. La problematización de la dependencia fue una novedad que armó un principio explicativo del desarrollo en la región y que se volvió tema recurrente en la obra de muchos intelectuales críticos, hecho que marcó la cultura política latinoamericana de las décadas siguientes en la medida en que el pensamiento revolucionario del continente contó entre sus banderas con la lucha antiimperialista.

En suma, afirma Funes, para un buen número de intelectuales de la década de los veinte del siglo pasado, la nación moró en un punto equidistante de la encrucijada formada por los conceptos de crisis, modernidad, tradición y revolución; así ubicada, para la autora, la nación es

más alrededor de la temporalidad que sobre la historicidad: una forma de vida que es más compleja que la comunidad; más simbólica que la sociedad; más connotativa que el país; menos patriótica que la patria; más retórica que la razón de Estado; más mitológica que la ideología; menos homogénea que la hegemonía; menos cerrada que el ciudadano; más colectiva que el sujeto; más psíquica que la urbanidad; más híbrida en la articulación de las diferencias e identificaciones culturales de lo pueden presentarse en cualquier estructuración jerárquica o binaria del antagonismo social (Bhabha, citado por Funes, 2006, p. 409).

Esta emergencia de cierto nacionalismo patriótico centrado en buscar núcleos de sentido en los orígenes ancestrales, propio de algunos países latinoamericanos, no estuvo presente en Colombia en las primeras 
décadas de siglo XX. Más bien, aquí existió la preocupación por edificar unos ciudadanos 'desinfectados' (Rojas, 2008), bajo la influencia de teorías positivistas y eugenésicas, que hizo que se desarrollara un pesimismo racial que trasladó a la nación la supuesta enfermedad de grupos poblacionales y la consecuente intervención de la higiene en función del bienestar y la salud de la sociedad ${ }^{17}$.

En síntesis, la nación se entiende como una comunidad de sentido en relación con el poder político y se circunscribe a los límites y prescripciones dadas por un Estado, para distinguirlo de otras formas de vínculo social. En segundo lugar, si bien el grueso de la literatura citada da cuenta de la génesis e historia de la nación, a los efectos del presente trabajo interesa sobre todo la nación vivida, es decir, "Ios procedimientos, las formas y rutinas por las que los actores aprenden a caracterizarse a sí mismos y al conjunto de la realidad social en términos de nación" (Bolívar, 2001, p. 12). Hablar de construcción de nación es acudir a la identificación de los dispositivos culturales que permiten que se refuercen los vínculos entre los sujetos que habitan una nación. Tales dispositivos, como se ha visto, no solo provienen de los nichos de sectores hegemónicos de la sociedad, ya que otros grupos buscan imponer significados y estilos sobre lo que significa ser colombiano, ser hombre o mujer, ser joven, vivir o luchar. "Es precisamente de este punto de donde arrancan los estudiosos que se preguntan por la forma como 'el pueblo' o los distintos grupos sociales 'negocian', 'traducen' y/o 'resisten' las formas de ser nacionales'” (p. 13).

\section{Identificación con la nación propia y escuela}

Desde la inauguración misma de la vida republicana en Occidente, la cuestión de la consolidación de la unidad nacional fue un problema para las naciones por circunstancias de índole geográfica, política, económica y cultural. En tal sentido, la educación siempre fue un

17 En un evento en la Universidad Nacional, en los años veinte, el médico Miguel Jiménez López, posterior ministro de Educación, en una conferencia titulada "Nuestras razas decaen. El deber actual de la ciencia" sostiene el degeneramiento racial de población colombiana con pruebas como la conformación anómala del cráneo, la obesidad inoportuna especialmente de las mujeres, defectos en la forma de las extremidades y anomalías en el aparato genital. "Como causas de estos males cita la 'viciación [sic] ancestral de nuestro legado étnico', la carencia de higiene, la educación viciosa y la miseria" (Rojas, 2008, p. 326). En forma similar, el político conservador y luego presidente de la república Laureano Gómez opinaba que el negro permanecía en una constante infantilidad y gozaba del don de mentir, el indígena — de raza salvajevivía en la miseria y la insignificancia, y del mestizo tampoco se podía esperar mucho porque en él se agudizaban las aberraciones psíquicas de las razas genitoras (Rojas, 2008). 
instrumento privilegiado para generar los sentimientos, conocimientos y habilidades proclives al imaginario de nación, y ello hizo que las políticas educativas fueran objeto de fuertes disputas desde el siglo XIX hasta la actualidad. Pese a fuertes confrontaciones y a los cambios de gobierno, los proyectos culturales dirigidos desde la escuela lograron imponerse a lo largo de décadas enteras sin grandes modificaciones; en tal sentido, la mayoría de investigaciones coinciden en señalar que para el siglo XIX y casi todo el XX la educación fue subsidiaria de un interés por hacer de ella herramienta cultural de identidad nacional, fue una institución forjadora de buenos patriotas y solo a finales del siglo XX y en los albores del XXI nuevas demandas replantearon este legendario vínculo.

\section{La escuela al servicio de la nación}

Para Urrego (2004), un antecedente destacado en la cimentación de la identidad nacional en Colombia fue la época de la Regeneración. En ella, como respuesta a un largo período de gobierno y política liberal, desde un Estado abiertamente conservador, clerical e hispanizante se produjo la institucionalización de símbolos cuya interiorización dotó a los colombianos de una conciencia más o menos común. Según el autor, la patria, el himno nacional, la bandera, el escudo, la fe y la moral católica inculcadas desde la escuela hicieron parte del currículo en el que crecieron varias generaciones.

En este contexto, la devoción a los símbolos patrios fue la vía expedita de forjamiento de sentimientos nacionales. Así, en un decreto oficial de 1904 se indicaba:

Artículo 58. Los cantos de las escuelas deben también contribuir al cultivo de estos sentimientos. Por tanto los niños cantarán todos los días, al terminar las respectivas tareas, el himno nacional colombiano.

Artículo 59. La bandera nacional es por excelencia el símbolo de la Patria y los maestros deben acostumbrar a los niños a saludarla, descubriéndose ante ella como ante una cosa venerable y sagra$d a^{18}$.

Según Betancourt (2001), para la segunda mitad del siglo XIX los esfuerzos por consolidar en Colombia la identidad nacional desde la escuela coincidieron con la producción intelectual presente en la literatura y 
el periodismo en especial. La nacionalidad se buscaba en la gesta y en los supuestos valores de los antepasados españoles. Dice este autor que a pesar de la intención de difundir un único pasado nacional en la década de los setenta existieron tres textos de historia patria ${ }^{19}$. En 1874 José María Quijano publicó por encargo presidencial el Compendio de historia patria, para ser utilizado en escuelas primarias, texto hecho en un gobierno liberal que no presentó grandes diferencias con lecturas protohispanistas o con obras posteriores como las de Enrique Álvarez Bonilla con su Historia patria en 1891.

Luego de la denominada guerra de los Mil Días ${ }^{20}$ y la separación de Panamá (1903), la clase dirigente emprendió la tarea de impulsar por múltiples frentes la unificación nacional. En este propósito la historia y su enseñanza tuvieron un papel estratégico. Se destacó la fundación de la Academia Colombiana de Historia, en mayo de 1902, como ente encargado de divulgar la memoria oficial del país ${ }^{21}$. Entre sus funciones estaban "proteger las reliquias históricas, consignar y preparar los días conmemorativos, promover el respeto de los símbolos patrios, preservar en la memoria popular a los artífices de la nacionalidad mediante estatuas y placas conmemorativas" (Betancourt, 2001, p. 84); además, la Academia tenía potestad para fundar academias regionales y supervisar y aprobar los textos para la enseñanza de la historia en el país. La Academia avaló para la época, previo concurso con motivo de la conmemoración del primer centenario de la independencia, un manual de historia cuyos autores fueron Jesús María Henao y Gerardo Arrubla ${ }^{22}$ en 1911, se trata del Compendio de la historia de Colombia, que se

19 El de José Antonio Plaza, el de José Benito Gaitán y el de José Joaquín Borda (Betancourt, 2001).

20 Confrontación partidista sucedida entre 1899 y 1902 cuyo resultado fue el triunfo del gobierno conservador y la separación de Panamá.

21 Según Betancourt (2001), dicha fundación es tardía respecto a otros países latinoamericanos, pues la de órganos similares como el Instituto Histórico y Geográfico de Río de Janeiro en 1838, el Instituto Histórico y Geográfico de Uruguay en 1843, la Facultad de Humanidades de la Universidad de Chile en 1843, el Instituto Histórico y Geográfico del Río de La Plata en 1854 y la Academia de Historia en Venezuela en 1888, expresan la preocupación meridiana de estas naciones por construir una memoria oficial del pasado nacional.

22 Ambos, miembros de la Academia. Arrubla (1887-1946) realizó estudios de Derecho y Ciencias Políticas en la Universidad Nacional, fue representante a la Cámara, alcalde de Bogotá, director de Instrucción Pública de Cundinamarca, de la Biblioteca Nacional y del Museo Nacional, además de juez del Circuito Civil y Criminal, fiscal superior de Cundinamarca y secretario de la Comisión de Límites con Venezuela. Henao (18701944) estudió Literatura en el Seminario Conciliar de Medellín y Derecho en el Colegio Mayor de Nuestra Señora del Rosario en Bogotá y en la Universidad Nacional; en Bogotá fue fiscal primero del Circuito, fiscal del Juzgado $2^{\circ}$ Superior del Distrito Judicial, juez del Circuito en lo Criminal, personero y secretario de Gobierno de Cundinamarca (Rodríguez, 2010). 
convirtió en la matriz de todos los textos escolares de ciencias sociales hasta finales de 1970.

Pese a la precaria escolarización colombiana durante el siglo XIX y principios del $X X^{23}$, lo que Ilevaría a cuestionar la incidencia de la escuela en la conformación de una identidad nacional, es importante referenciar que la labor de la Academia y del Compendio de historia de Henao y Arrubla marcaron una poderosa guía de lo que circuló por otras fuentes, especialmente por los medios de comunicación.

Alexis Pinilla (2003) profundizó en el estudio de este compendio y caracterizó a sus autores como herederos de la tradición ideológica del período de la Regeneración y, como tales, perpetuadores de las ideas conservadoras. La invisibilización de los pueblos aborígenes, la idealización de los próceres nacionales, la naturalización de la república como la nueva madre patria - al punto de exigir dar la vida por ella - y la devoción religiosa fueron los pilares de la identidad nacional en el texto en mención. Para Pinilla, otro componente destacado consistió en la valoración que sus autores hicieron del hispanismo, tendencia incluso destacada en los líderes de 1810, que en el acta de independencia reconocían como monarca del Nuevo Reino al de España, siempre y cuando viniera a Santa Fe a gobernar.

En suma, el texto de Henao y Arrubla materializó el proyecto político de las élites de principios del siglo XX, que buscaba imponer un orden político caracterizado por el

retorno a concepciones medievales sobre subordinación del poder temporal al poder espiritual, la Iglesia como elemento cohesionador de la sociedad, la supeditación de la ley a la moral y el cambio del ciudadano burgués (inspirado en la Revolución francesa) al ciudadano católico virtuoso (Urrego, citado por Pinilla, 2003, p. 114).

Llama la atención que durante más de seis décadas la enseñanza de la historia en el país no presentó mayores modificaciones ni aportes de

23 Dice Marco Palacios (2003) que en 1870 estaban registrados 82.561 estudiantes, que representaban el 5,3\% de la población en edad escolar; la participación femenina en la matrícula era del 27\%. En 1899 unos 140.000 niños estaban matriculados en las escuelas primarias. El censo de 1912 señaló una tasa de alfabetización del 17\% para los 4'130.000 colombianos de más de 8 años que existían en el país.

Según Helg (1987), en 1918, según un censo oficial, solo el 32,5\% de los habitantes mayores de 10 años sabían leer y escribir.

Por su parte, para Herrera (2007), en 1928 la población en edad escolar era de 7'121.000 habitantes, de ellos el 5,68\% recibía educación y de estos el 30\% correspondía a Educación Primaria. 
otras lógicas, al menos en la estructura ideológica ni en la estrategia pedagógica de un libro de texto oficial. "Las discusiones pedagógicas que se llevaron a cabo años después en el país no se consideraron en las reediciones, tampoco se modificó la estructura narrativa de la obra, a pesar de la ampliación en la producción historiográfica" (Rodríguez, 2010, p. 28). Ello es una muestra, en Colombia, de lo poco permeable que ha sido la enseñanza de la historia a influjos de otras ciencias sociales y el papel subsidiario que ha jugado frente a intereses políticos.

En un trabajo reciente de Sandra Rodríguez (2010) sobre este compendio, que buscaba establecer los referentes de la memoria oficial en la historia del país, la autora devela, desde una perspectiva foucaultiana, una estructura en el texto caracterizada por un orden determinado inscrito en una línea cronológica de progreso, en la que se ensalza a los conquistadores que fundaron la patria, una verdad histórica que se impone al sujeto escolar como una prescripción de hechos observables y un conjunto de valores heredados del pueblo español. Las lecciones morales del Manual, selladas en las entradas de los discursos, que invitaban al amor y al cumplimiento del deber, al acatamiento de la autoridad y la tradición y al seguimiento del ejemplo de los próceres, implicaban que

el maestro y el niño escolar [...] se debían constituir a partir de estos enunciados, establecerían su interacción en función de la afirmación, el mandato y la indicación, subordinando sus perspectivas individuales a los intereses de la patria, es decir, a los de la élite y la lglesia" (Rodríguez, 2010, p. 39)24.

En el compendio se sacralizó el suelo patrio y se convocaba al lector a su defensa y conservación, se apelaba a un patriotismo hasta la muerte por los símbolos nacionales y, según Rodríguez, se transmutó en el "ejemplo de los buenos" a un conjunto de individuos, representados en la élite, legítimamente autorizados para Ilamar a la guerra, promulgar la memoria, defender la tradición y encarnar la autoridad.

En otro sentido, Álvarez (2007) apuntó como un período clave en la articulación de la escuela a la modelación de la identidad nacional, el que va de 1930 a 1960, y destacó el papel de la enseñanza de las ciencias sociales como impulsora de la nacionalización del pasado, el territorio y el pueblo. El autor, preocupado por demostrar el estatuto epistemológico del saber pedagógico no dependiente del científico, y por rastrear incluso la forma como la enseñanza de la historia precedió 
la configuración de la historia como disciplina en el país, menciona que

la enseñanza de la historia, la geografía y la cívica en primaria y secundaria [...] son tan solo el lugar por donde pasó la pretensión de formar una identidad nacional que le daría cuerpo a ese modo de ser colombianos durante ese período (Álvarez, 2007, p. 74).

Estas décadas de auge del nacionalismo terminaron en los sesenta, según Álvarez, porque en Colombia se sintió el impacto en el mundo cultural, político y económico del impulso de la globalización con el replanteamiento que acarrea de lo nacional. Se comenzaron a borrar las fronteras y ser colombiano será otra cosa.

En aquellas décadas, lideradas por el Partido Liberal en el poder, se quiso separar una escuela con cobertura creciente de los valores religiosos, no sin conflictos con la Iglesia, los poderes regionales y las comunidades locales que valoraban la tradición y las costumbres. Desde el Estado se construyó la identidad nacional por medio de lo que el autor Ilama una pedagogía social, en ella "la educación fue la estrategia, lo social fue el objetivo, la escuela y las ciencias sociales fueron los medios, y el Estado nación fue el resultado" (Álvarez, 2007, p. 100).

Una investigación sobre manuales escolares del siglo XIX en el Caribe colombiano, de Alarcón y Conde (2003), identificó en los textos de la región la búsqueda de un individuo formado dentro de los parámetros de la razón y la virtud; en este período republicano los ideales unificadores constituyeron la garantía del orden y la estabilidad de la nueva sociedad. Los autores acuñan el término de pedagogías cívicas para referirse a los procesos educativos a través de los cuales se divulgó el discurso republicano y liberal que justificaba la aparición del nuevo régimen basado en la soberanía popular. Estos textos mostraban las bondades de la república, las sobradas razones para su defensa, la trascendencia de la nación y del hombre cuyo modelo era el cumplimiento de las reglas de urbanidad. La historia centrada en los héroes y en las gestas libertarias ocupó no solo las páginas de los textos, sino las manifestaciones populares y actos cívicos dentro y fuera de la escuela.

En la misma línea de análisis de los textos escolares, una investigación obligada para rastrear los vínculos de la identidad nacional y la realidad escolar fue la realizada por Herrera, Pinilla y Suaza (2003). En ella se analizó lo sucedido en la primera mitad del siglo XX a partir de lo expresado en los manuales escolares de historia, geografía e instrucción cívica. Para estos autores la identidad nacional fue un modelo impuesto 
que enfatizó en lo que se debía ser, a costa de lo que se había sido, impulsada desde unos instrumentos doctrinarios y cerrados - los libros de texto- cuya estructura no daba lugar a preguntas ni mucho menos a cuestionamientos del orden social vigente. La historia tuvo la misión de incrementar el sentimiento patriótico a través del reconocimiento de los héroes nacionales y las gestas militares que se dieron en la independencia; por su parte, la geografía, que versaba sobre el conocimiento y uso del territorio, impulsaba la capacidad en los estudiantes de explotación de las riquezas del país; y la instrucción cívica se inclinaba por inculcar ideales patrióticos, es decir, hábitos de disciplina, orden y respeto a las autoridades y la iconografía patria. Para dichos autores

se pudo establecer que el proceso de construcción de identidad nacional, estuvo directamente articulado a la construcción del proyecto político del Estado nación, entendido como proyecto de élite, que dejó de lado la diversidad cultural y la pluralidad de las expresiones políticas existentes en el país conduciendo, a la vez, a la sustitución de lo nacional por lo estatal y a la imposición de un modelo de cultura política distanciado del discurso democrático promulgado por las clases dirigentes del país (Herrera, Pinilla \& Suaza, 2003, p. 178).

Cabe destacar el papel de la religión católica como modelo de ciudadanía virtuosa, estandarte del alma nacional y garante del orden y la ley. En los libros de escuela la Iglesia, cuando no era la encargada directa de realizarlos, daba el aval para que los contenidos no estuvieran en contra de las creencias religiosas.

En esta línea de textos escolares vale la pena una mención a un estudio en la Argentina (Romero, De Privitellio, Quintero \& Sabato, 2004). Delimitado a la segunda mitad del siglo XX, los autores argumentan sobre el reduccionismo que operó en los manuales escolares por medio del uso de los mapas, la celebración de las efemérides y la imagen proyectada de Constitución. La historia, la geografía, el civismo, disciplinas privilegiadas para rotular la idea de identidad nacional, resaltaron a principios del siglo XX un destino de grandeza para la nación, asociado a la prosperidad económica, la unidad exterior y la expansión. Promesa frustrada que "dio lugar a una actitud entre soberbia y paranoica: había responsables del fracaso argentino, enemigos que se encontraban fuera - los vecinos celosos... - antes de que, a la luz de las doctrinas de Seguridad Nacional, comenzara a buscárselos adentro" (Romero, De Privitellio, Quintero \& Sábato, 2004, p. 23). También en los textos se vinculó con fuerza al destino de nación la institución militar y la Iglesia, y transmitió una imagen estereotipada de los enemigos que su- 
cesiva y alternativamente se encarnó en Estados limítrofes o en peligros lejanos, y que también podía alojarse en el mismo suelo patrio. Nación unitaria, preexistente, esencialista, sacrificial, trascendente, fundada en el territorio y su defensa, tal era la imagen de la Argentina proyectada en los manuales escolares.

Como se afirmó atrás, a finales del siglo XX algunos estudios reconocen el cambio de horizonte en la misión de la enseñanza de las ciencias sociales en el continente y para el país, en el que la tradicional función de la escuela hacia la inculcación de sentimientos patrios ya no es tan clara. Este es justamente el tema que insinúa el siguiente conjunto de investigaciones.

\section{¿La nación al servicio de la escuela?}

La investigación de Samacá (2009) pregunta por el tipo de memoria nacional que en el pasado reciente - 1984-1997- transmitieron los textos de ciencias sociales en octavo grado. Considera que este material fue afín al ideal constitucional de 1991. Al respecto afirma que

el respeto y el reconocimiento del otro, la necesidad de resolver las diferencias a través del diálogo o la recreación de pequeñas asambleas constituyentes al interior del salón de clase, fueron formas "prácticas" de acercar a los estudiantes al momento histórico en que se encontraban y de hacerlos pequeños ciudadanos con espíritu democrático (Samacá, 2009, p. 286).

Los textos evidencian la tensión entre la naciente incorporación del país al mercado globalizado con elementos cercanos a la producción de nacionalidad y democracia. Esta transición, según Samacá (2009), tuvo como trasfondo el repliegue de la Academia Colombiana de Historia como orientadora de los textos de historia por el protagonismo adquirido por las universidades públicas y privadas, y sobre todo, el impulso de la llamada "Nueva Historia", movimiento intelectual liderado por Jaime Jaramillo Uribe y Jorge Orlando Melo, entre otros. A su vez, para esta época se dio en el país la creciente profesionalización de la enseñanza en general y de las ciencias sociales en particular, además se empezó a hacer evidente la presión de organismos multilaterales por "modernizar" el sistema escolar y "actualizar" los contenidos de la enseñanza, incluida, por supuesto, la historia y los textos escolares.

Samacá repara en las limitaciones que tuvo la producción historiográfica del período estudiado para permear los manuales escolares. Los re- 
sultados: retazos de historia socioeconómica que naturalizaron el liberalismo; fragmentos de la política que daban mayor peso a la época de la República como generadora de identidad nacional y que fortalecían el mito de la esencia profundamente democrática que supuestamente nos ha acompañado, y ausencia de conflictos entre grupos sociales o regionales. Así, los textos de ciencias sociales de finales del siglo XX, para el autor, contribuyeron a la creación del imaginario de un nosotros más allá de las desigualdades y diferencias que estableció continuidades entre el siglo XIX y el XX, y

siguieron cumpliendo la función de servir de soporte para la invención de la nación en el plano simbólico, articulando elementos "tradicionales" como los que procuraban una adscripción territorial y algunos más "actuales" como el reconocimiento e incorporación de la diversidad regional a nivel interno y la integración continental y mundial (Samacá, 2009, p. 295).

A propósito de miradas sobre realidades contemporáneas, Hoyos, Del Barrio y Corral (2004) en un estudio comparado con niños y jóvenes de Colombia y España se propusieron explorar las concepciones de identidad nacional y sus posibilidades de cambio a partir del desarroIlo de varios temas: representación de la identidad nacional, descripción del propio grupo, actitudes hacia los símbolos patrios, conocimiento sociogeográfico y actitudes hacia los extranjeros. Los autores coinciden en señalar la idea que tienen los escolares respecto a la esencialización de la nación; sin embargo, el énfasis que ponen en lo legal en sus análisis lleva a confusiones de orden teórico al homologar nacionalidad e identidad nacional. Las reflexiones de los autores se remiten a extender las entrevistas de los investigados sin problematizar sus afirmaciones y sin discusión con marco referencial alguno. No hay mirada a la historia ni cotejo con los mecanismos estatales de construcción de nación; además, de sus conclusiones Ilama la atención que afirmen que la nacionalidad no depende para nada de aspectos legales, sino solo de aspectos culturales, y que tal dependencia podría obstaculizar la convivencia en una sociedad plural. Sobre este particular sugieren: "resulta importante incluir en los currículos escolares una concepción más relativista o más cosmopolita, para evitar el posible riesgo de que se asuman posiciones fundamentalistas implícitas en una visión esencialista" (Hoyos, Del Barrio \& Corral, 2004, p. 107). Dejan de lado inferencias valiosas que conecten el dispositivo escolar y la sociedad, el uso histórico de la enseñanza de las ciencias sociales o la formación social de los dos países como contexto de las identidades estudiadas. 
Profundizando en relación con Argentina, Kriger y Carretero (2010) documentan, en una amplia investigación con estudiantes argentinos, el importante papel desempeñado por la escuela como instrumento histórico para distribuir y legitimar, no solo conocimientos, sino identidades nacionales. Al respecto, estos autores se preguntan cuál debería ser la función de la enseñanza de la historia en un mundo posnacional: ¿Contribuir a la formación de nuevas ciudadanías globales y supranacionales? ¿Preservar las identidades locales y nacionales frente al avance de la globalización? Su estudio, realizado con jóvenes del sistema escolar argentino, concluyó que pese a declarar los programas de historia que se distancian abiertamente de la formación nacionalista, y a que los docentes que imparten esta asignatura dicen orientar su práctica hacia la formación de conocimientos críticos, el anhelo de identidad nacional continúa presente y configura una dimensión emotiva importante en la enseñanza de la historia de este país.

Luego de indagar por la concepción de nación, por el reconocimiento de los agentes históricos y por el reconocimiento del conflicto en ciertos hechos históricos, los autores destacan el abuso de los objetivos identitarios en desmedro de los cognitivos en la enseñanza escolar, en particular en la celebración de las efemérides; ello inhabilita en los escolares la posibilidad de cuestionar los relatos del pasado y compararlos con otras versiones, de manera que se sigue "detectando un núcleo de creencias previas, de tipo nacionalista, que mantiene activa una fidelidad profunda a la nación, que se expresa como un imperativo moral con el pasado que obstruye el compromiso ético político con el presente y el futuro" (Kriger \& Carretero, 2010, p. 78).

Miriam Kriger (2010), en otro estudio, demuestra que la identidad nacional era vista como preexistente al Estado y la nación teleológica irrumpió como trascendente a la historia, también a partir de un estudio con jóvenes universitarios, hijos de la crisis política y económica de la Argentina de 2001. Ello representa en términos políticos un enorme riesgo, según la autora, ya que estas explicaciones no presentan a los sujetos como constructores de sus historias sino como seres sujetados u objetos construidos por una Historia — con mayúscula — que les tiene una misión predeterminada. Lo cierto es que la comprensión histórica de los jóvenes no pareció compadecerse con sus deseos de edificar un proyecto común, dado que si bien apuntaban las carencias del Estado, eran incapaces de desarrollar un discurso crítico sobre el pasado "y su estrategia más inmediata para resolver esa falta es compensarla con identidad nacional, un recurso altamente disponible tras doce años de escolarización" (Kriger, 2010, p. 215). Se produjo así lo que Kriger lla- 
mó una hipertrofia identitaria, que intentaba saldar este vacío a partir no de reflexión política, sino de refundación nacional, es decir, de desvinculación o amputación de la potencialidad política de alternativas posibles. Por ello, para Kriger es necesario brindar herramientas cognitivas y disciplinares a los escolares a fin de entender su pasado pero tomando distancia de él, que entiendan el conflicto, la contingencia de los fenómenos históricos y el papel de los sujetos en ella, incluidos ellos mismos como estudiantes.

Sobre este mismo país, un estudio muy pertinente a los efectos de esta investigación lo constituye el trabajo de Alexander Ruiz (2009), que tuvo como propósito indagar las representaciones de estudiantes argentinos sobre los relatos de nación aprendidos en la escuela. El estudio encontró una construcción narrativa de nación esencialista y defensiva por parte de los escolares. El autor señala que era escasa la formación histórica en la escuela y que los estudiantes reproducían una suerte de saga $^{25}$ nacionalista y patriótica. La apelación a la emoción y a los afectos a la hora de evocar los hechos históricos generaba en los escolares sentimientos de

admiración y aprobación más allá de que el contenido de lo narrado y el papel de sus protagonistas admita críticas o incluso una actitud de distanciamiento, como se puede constatar en algunos de los relatos orales y argumentales de los estudiantes (Ruiz, 2009, p. 344).

Un perfil romántico del pasado aprendido, un rol moral asignado a los héroes de la independencia y un destino teleológico a la nación fueron algunos de los hallazgos relevantes de la pesquisa. Además reveló en los jóvenes una identidad nacional cerrada que hacía las veces de una religión cívica que presentaba dificultades para admitir cuestionamientos o críticas a la historia oficial aprendida.

Con un objetivo muy similar a la anterior investigación, Ana Pereyra (2007) analiza la producción escrita de jóvenes que narran su nación entre 1973 y 2003 a un supuesto extraterrestre que desconoce su pasado. La mayoría de estudiantes evoca la dictadura militar y la impugna por las violaciones a los derechos humanos y las afrentas a la sociedad civil, sin embargo este discurso generalizador no da cuenta de matices y conflictividades claves para el período, en particular no da información sobre la cultura política argentina antes y después del golpe,

25 Analogía de un género literario de matriz oral en el que se juntan memorias y narraciones del pasado y en el que se articulan elementos de tipo histórico y social. 
tampoco identifica la trayectoria de las víctimas, ni el modelo económico en curso durante el proceso. Para la autora esta representación del pasado bloquea la pregunta por los procesos políticos, sociales y subjetivos que condujeron al terrorismo de Estado y por los distintos niveles de responsabilidad que tuvo la sociedad civil, además de obstruir cualquier conexión con el presente que implique la comprensión de la heterogénea realidad actual.

Por su parte, el estudio de Higuera (2010), centrado en el tratamiento de la transmisión de la memoria reciente en la escuela argentina, indaga por las representaciones de jóvenes estudiantes de secundaria a partir de sus procesos de socialización en dos colegios de sectores medios de Buenos Aires. Luego de observaciones de aula y entrevistas a docentes y estudiantes este autor considera que para la mayoría de los escolares la reconstrucción del pasado reciente opera fundamentalmente a partir de las imágenes que proporcionan los padres, los medios de comunicación y el sentido común. Estas representaciones estuvieron cargadas de recortes y sesgos que, si bien reconocieron un período autoritario en su historia, desconocieron aspectos complejos y relevantes como la identidad de las víctimas, las causas de los hechos y las consecuencias políticas y económicas para el país. Según el autor, paradójicamente convive en los jóvenes una yuxtaposición discursiva en la que incluso flotan argumentos de la dictadura militar. Higuera (2010) concluye que "la escuela puede retomar el sentido común, enriquecerlo, complejizarlo y relacionarlo con la formación de valores democráticos, o bien puede reproducir una transmisión dispersa y fragmentaria que recurra a estereotipos, contribuyendo así a una cristalización del pasado" (p. 175).

En un proyecto que pregunta por la identidad nacional en Brasil, Pugas (2008) indagó a estudiantes de quinto grado de varias escuelas, desde el análisis del discurso, por diferentes aspectos de la historia de su país y el sentido de pertenencia. Los estudiantes dijeron sentirse vinculados en las prácticas deportivas, en paisajes turísticos y en bellezas naturales exaltadas por los medios de comunicación, así como en las clásicas jornadas de himnos, banderas y carnavales. La autora Ilamó híbridas a estas adscripciones que mezclaban aspectos del pasado y del presente, de la historia y de la cultura, del mercado y del folclor, y que perfilaron el sentido de la brasilidad de los escolares. Aquí la impronta de la escuela no fue clara, en particular la enseñanza de la historia, y más bien se reflejó la apropiación de un discurso mediático que ponía énfasis en lo exótico y en el 'paraíso natural' que se exportaba para el turismo y que los estudiantes mezclaron con la información que recibieron de la escuela. 
Para el caso español López Facal (2000) destacó cómo los esfuerzos iniciales de intelectuales del siglo XIX por crear un imaginario nacional se truncaron por la precariedad del Estado, ya que ese discurso no era asumido por una población mayoritariamente analfabeta. Sin embargo, con el tiempo se fue construyendo la idea de nación y de pasado que se plasmaría en manuales escolares: "La historia debía ocuparse de transmitir la identidad nacional — la esencia de lo español— que se consideraba inmutable: la unidad nacional, el carácter de los españoles y su religiosidad" (p. 113). Para dicho autor la existencia de un carácter nacional, difundido por los escritores románticos, estuvo presente en los textos desde mediados del siglo XIX hasta la etapa final del franquismo, y no solo, como suele pensarse, en los manuales de franquistas o ultraconservadores. Sin embargo, es de destacar el fracaso del concepto de nación difundido por el nacional-catolicismo franquista, no solo por las urgencias del proceso modernizador, la escolarización y el secularismo, sino por su carácter excluyente, lo que le hacía adolecer de la virtualidad político-ideológica más potente de cualquier nacionalismo, como es la cohesión social interclasista en un sistema de valores y referentes simbólicos compartidos.

Afirma López Facal que para la década de los setenta del siglo XX, a tono con las transformaciones de la posguerra y con lo que otros investigadores comentan para sus países, la historiografía escolar española abandonó el cariz nacionalista y xenófobo, que se consideraba inadecuado para los nuevos bloques de poder internacional que se perfilaban (Organización del Tratado del Atlántico Norte - OTAN, Organización para la Cooperación y el Desarrollo Económicos - OCDE, comunidades europeas...). La enseñanza de la historia se acomodó desde entonces a este lugar común: cultura grecorromana, la difusión del cristianismo, el feudalismo, el Renacimiento, la Ilustración, la Revolución Industrial, el capitalismo, las revoluciones liberales, etc. Bajo esta connotación, la nueva comunidad imaginada, que borra particularismos, que inventa nuevas tradiciones, que incluye a unos pero excluye a otros, que impone símbolos comunes, se reedita desde una nueva perspectiva.

Pese a estas nuevas demandas, persistió en los textos escolares la concepción de nación española como viva y eterna que determinaba la existencia de unas características comunes a toda la población y que condicionaba la organización política. Menos explícito en los discursos expuestos de los manuales, estaban aún presentes en los mapas históricos, los documentos, las actividades complementarias o los enunciados de formación cívica. En conclusión, sentencia López Facal, persistieron prejuicios arraigados sobre la nación y la identidad nacional 
en los manuales escolares de historia, que no incorporaron los nuevos enfoques sobre la investigación académica, aunque no reprodujeron los desfasados estereotipos nacionalistas del pasado.

En un análisis para el caso de Estados Unidos, Vansledright (2008) indicó la importancia que tiene la enseñanza de la historia como un asunto de orden público, dada la preocupación estatal ante la enorme cantidad de inmigrantes que se dan en este país $(11,4 \%$ de la población total). Según estas políticas, se pretendió americanizar a los extranjeros desde la escuela a partir del aprendizaje de la historia oficial y eliminando de la memoria a otros pasados particulares y del aporte que otras razas han hecho a la construcción de su nación. El autor señaló con pertinencia la manera como Estados Unidos ha perfilado su nacionalidad a partir del poder desarrollado para denigrar y excluir a negros, indios, católicos irlandeses, asiáticos del sur, europeos del este, comunistas, anarquistas, homosexuales, que "han servido como 'otros' contra lo que 'nosotros' hemos definido nuestra americanidad" (Gestle, citado por Vansledright, 2008, p. 111).

Los textos de Estados Unidos plasman la imagen de los líderes de la política, empresarios, industriales e intelectuales destacados de la historia, con énfasis en los logros de hombres anglosajones. El tema principal, según el autor, ha sido el destino manifiesto en tanto vocación histórica y natural a la libertad, la democracia y la grandeza de un país. Invisibilización de los conflictos, silenciamiento de otras narrativas, voces omniscientes y atemporales, han sido las constantes en los manuales escolares, los que a su vez impusieron el guion a los maestros en la interacción de las escuelas de Estados Unidos. Hay que entender que existe una cultura sobre el uso de los textos escolares en las escuelas, son referentes obligados, máxime cuando su oficialización está respaldada por el gobierno, por las evaluaciones censales o por estándares de aprendizaje en algunos estados.

A partir de una diferenciación entre historia y consumo de patrimonio o memoria colectiva, Vansledright afirma que lo que hacen las escuelas es más lo segundo, pues se acude a un acto de fe en el pasado, a una conmemoración colectiva. ¿Qué efectos produce en los estudiantes? Sirviéndose de otros estudios, el autor plantea que estos imaginarios producen lealtades acríticas al Estado nación desde la Primaria hasta la Educación Superior, una "historia temática lineal, simple y optimista del desarrollo nacional (con una lista abreviada de los héroes americanos, los mártires, y los padres)" (Vansledright, 2008, p. 124). 
También sobre los manuales de Estados Unidos, Alridge (2006), tomando el caso del uso que se dio en estos a la historia de Martin Luther King, señala el reduccionismo y la simplificación efectuados en este procedimiento al mostrar los momentos del pasado como pasos o fases hacia la realización plena de la democracia en el país. Se niega a los estudiantes la posibilidad de juzgar y analizar los hechos, de complejizarlos y contrastarlos, más bien "encuentran una historia aburrida, predecible e irrelevante" (p. 663), incapaz de conectar con lo contemporáneo y con el mundo, particularmente con los actuales problemas de racismo y pobreza. Como conclusión, la autora sugiere a los docentes de historia minimizar el uso de textos, ofrecer acceso a otras fuentes y dar la posibilidad a los escolares de construir sus propias interpretaciones, fomentar el debate y animarlos para hacer conexiones entre el pasado y el presente.

En la misma línea, Löw-Beer (2003), refiriéndose al sistema escolar británico, afirmó que, al igual que en la mayoría de países europeos, predomina en la enseñanza de la historia la descripción de una historia nacional desde un enfoque ya no político, sino económico y social. Para la autora, esta enseñanza es más selectiva, menos autoritaria y monolítica de lo que solía ser, en parte por el método que privilegia el acceso directo a fuentes y no tanto a textos escolares, con "la intención de obtener en los alumnos un pensamiento acerca de la evidencia para la historia, y mirar desde diferentes perspectivas" (Löw-Beer, 2003, p. 2). Pese a ello en este país, afirma la autora, se sigue separando la historia nacional de la extranjera, a diferencia de otras naciones que contextualizan su historia en un ámbito regional, como Escocia, Gales o Irlanda. La historia nacional que se oficializa en las escuelas busca contribuir al fortalecimiento de la identidad nacional, aunque hay poca evidencia empírica para ver hasta qué punto esto se logra. Por ejemplo, en Escocia ha habido poca enseñanza de historia escocesa en sus escuelas, sin embargo, el sentido de identidad nacional y cultural ha crecido a buen ritmo. La autora cuestiona el papel que la escuela debe desempeñar en la creación de estos vínculos, pues aclara que de entregarse a esta tarea siempre terminará convertida en instrumento de propaganda nacionalista, ya que "un sentido de identidad, ya sea personal o nacional, es algo que al final, los alumnos forjan por sí mismos, y es hecha de muchas fuentes" (p. 7).

En resumen, con Mario Carretero (2007) se podría decir que si bien en la mayoría de países occidentales (según el autor también en China, Japón, Corea) la escuela y la enseñanza de contenidos escolares tuvieron un fuerte compromiso en la transmisión de sentimientos nacionalistas y 
como tal promotores de identidad nacional durante el siglo XIX y buena parte del XX, la década de 1990 expresa un importante cambio de perspectiva en un número considerable de países, fruto de una reconsideración del pasado desde la historia académica y con repercusiones en la historia escolar. Para Carretero, tales replanteamientos tienen en común varias cosas: a) búsqueda de una nueva relación entre la representación del pasado y la identidad, sea nacional, local o cultural; b) reclamo de historias menos míticas y más objetivadas; c) nueva mirada sobre los conflictos del pasado con miras a emprender proyectos futuros, y d) necesidad de hacer comparaciones entre historias alternativas de un mismo pasado.

Según Carretero, en esta transición se hace evidente la doble función de la escuela, que desde su nacimiento obedecía, por un lado, a un proyecto ilustrado-cognitivo, y por otro a uno romántico-nacionalista, y que luego de casi dos siglos de abnegado servicio a la patria pareciera estarse deslizando hacia la formación del ciudadano global.

Los sistemas escolares sienten el impacto de un mundo globalizado que cuestiona el sentido tradicional de las fronteras nacionales, de un mercado que reclama nuevas condiciones y habilidades en los ciudadanos del planeta, pero también de multitud de grupos étnicos, sociales y culturales que exigen el lugar y los derechos que los discursos homogeneizadores les han negado.

Tal tensión se particulariza en cada país, incluso en cada región, en cada escuela. Vale la pena ver en detalle cómo "el presente se configura como un momento de transición en el que lo nacional y lo posnacional luchan en el interior de las instituciones que, como la escuela, necesitan renovar su legitimidad" (Carretero, 2007, p. 288). O analizar cómo ese pasado, esa huella de la historia épica decimonónica aprendida en la escuela emerge, resiste o coexiste con postulados contemporáneos que defienden valores democráticos, universales y supuestamente respetuosos de los otros. 


\section{VÍNCULOS Y ADSCRIPCIONES A LA NACIÓN PROPIA}

Las naciones y los fenómenos asociados con ellas deben analizarse en términos de las condiciones y los requisitos políticos, técnicos, administrativos, económicos y de otro tipo. Por este motivo son, a mi modo de ver, fenómenos duales, construidos esencialmente desde arriba, pero que no pueden entenderse a menos que se analicen también desde abajo, esto es, en términos de los supuestos, las esperanzas, las necesidades, los anhelos y los intereses de las personas normales y corrientes, que no son necesariamente nacionalesy menos todavía nacionalistas.

(Hobsbawm, 1991, pp. 18-19) ${ }^{1}$

Como ya se indicó, es un lugar común en las ciencias sociales afirmar que la nación es una construcción histórica de reciente aparición (Gellner, 1988; Hobsbawm, 1991; Smith, 1997; Bolívar, 2001) y que para afianzar su presencia y permanencia fue clave la inculcación de sentimientos de adhesión y pertenencia entre los pobladores de los Estados, en tanto conflictivas unidades político-territoriales (Hobsbawm \& Ranger, 1983).

Para el mantenimiento, funcionamiento y reproducción de los Estados nacionales fueron y son importantes las políticas destinadas a generar sentimientos de hermandad entre los conciudadanos y de lealtad e identificación con el aparato político-institucional que ampara o domina la sociedad (Anderson, 1993). En este punto es que se articula el valor de la identidad nacional, ya no mirada solo desde una fuerza vertical que emana del poder estatal y que procura adeptos, sino como espacio e imaginario social de consumo, resistencia o producción por parte de los sectores sociales que asimilan tales ideas. Como lo afirma Eric Hobsbawm, a tono con el epígrafe del presente capítulo, la mirada desde abajo, o sea, "la nación tal como la ven, no los gobiernos y los portavoces y activistas de movimientos nacionalistas (o no nacionalistas), sino las personas normales y corrientes que son objeto de los actos y la propaganda de aquellos, es dificilísima de descubrir" (Hobsbawm, 1991, p. 19). Tal dificultad radica, en parte, en la escasa producción empírica que dé cuenta sobre la forma como dichas personas normales asimilan la nación.

$1 \quad$ Cursivas fuera del texto. 
Sin embargo, algunos estudios recientes asumen el reto que las palabras de Hobsbawm plantean, en torno a indagar la nación que subyace a los discursos oficiales; en tal sentido, los análisis sobre la construcción de nación se enriquecen con este grupo de trabajos, que llaman la atención sobre la pertinencia de ahondar en:

[...] los procedimientos, las formas y las rutinas por las que los actores aprenden a caracterizarse a sí mismos y al conjunto de la realidad social en términos de nación. [...] Se trata de analizar las dinámicas sociales que permiten que, en la vida cotidiana, se refuercen, se fortalezcan y afiancen los vínculos sociales que constituyen la nación. Es pues un esfuerzo por mostrar los complejos dispositivos que permiten "inscribir culturalmente" la idea de nación y que sostienen los distintos esfuerzos por leer las sociedades en esos términos (Bolívar, 2001, p. 12).

Para Bolívar, los estudios sobre los discursos de nación, y derivaríamos sobre la identificación nacional, quedan incompletos sin la comprensión de las condiciones de interdependencia social que sostienen y alimentan las percepciones que se crean sobre la nación misma, es decir, no basta tener en cuenta la transformación de los procesos y factores objetivos respecto a la alfabetización, las plataformas de comunicación, la industrialización, la burocracia estatal, la élite intelectual, etcétera, que mencionan los autores clásicos (Hobsbawm, Gellner, Anderson, Smith) para explicar cómo funciona y se mantiene la identidad nacional, sino que es importante complementarlos con el estudio de los consumos culturales y las representaciones políticas que circulan sobre lo que significa pertenecer a una nación, identificarse con ella.

Resulta pertinente entender la idea de identidad nacional como un proceso, por lo cual sería más preciso el término identificación (Ruiz \& Carretero, 2010), lo que implica abordarla no como un estado o situación acabada y estática, sino fundamentalmente como un proceso en el que existen momentos cambiantes, opciones no exentas de conflictos y contextos particulares que contribuyen a perfilar adscripciones en tiempos y espacios históricos específicos y que se articulan con otras subjetividades en formación (Giménez, 1993). Además, dado que confluyen varios tipo de adscripción identitaria en una misma persona, la identificación se entiende como el ejercicio de dar prioridad a una o más adscripciones sobre otras, dada la naturaleza multidimensional del ser humano (Hobsbawm, 1994). Hablar de identificación nacional permite comprender la contingencia de las vinculaciones que los sujetos enuncian, en el escenario de opciones específicas, de apuestas políticas y de coyunturas que les permiten posicionarse individualmente, en tanto parte de un colectivo social. 
Tal identificación se construye en un doble sentido: por una lado, deviene en realidad fruto de contextos sociopolíticos y económicos concretos que ofrecen posibilidades materiales para la reproducción social y que por tanto inciden en las experiencias biográficas de los sujetos (Bauman, 2001), por otro lado, se arma en tanto construcción discursiva frente a la pregunta por el ser, de forma que la identificación "se reitera en el intento de rearticular la relación entre sujetos y prácticas discursivas" (Hall, 2003, p. 15). Así que está sujeta a múltiples fuerzas que pugnan por darle forma, o mejor, su forma plástica resulta de la convergencia de las muchas demandas, internas y externas, que el sujeto experimenta a lo largo de su existencia y cuyo resultado final, aunque transitorio, se resuelve en la respuesta a la pregunta: ¿quién soy?22. Por ello es problemático invocar coherencia o tener expectativas frente a regularidades respecto al pasado-presente-futuro de las adscripciones identitarias.

En este trabajo se tomó la fotografía en función de su sentido y propósito, por ello se ha preferido la denominación relatos o textos visuales, por cuanto se asume como una herramienta de análisis, como "una construcción cultural producto de una conciencia política y estética anclada en determinado espacio y tiempo" (Giordano \& Reyero, 2001, p. 15). Desde esta perspectiva, interesaron menos los asuntos epistemológicos y teóricos ligados a producción de la imagen, y mucho más la potencialidad heurística que reviste como recurso narrativo capaz de ofrecer caminos para que el sujeto se exprese. Por eso vale decir que el ejercicio interpretativo que se propone en el presente apartado no es una semiótica de la fotografía, sino un análisis de distintos documentos que provienen de varias fuentes: escritas, orales y visuales, a propósito de la identidad nacional. En tanto palabra visual, la fotografía se reveló a lo largo del trabajo de campo como un medio privilegiado para hacer visible la identidad:

Proponer pensar una identidad narrativa en su relación con la fotografía significa, en el punto de partida, suponer que la identidad que la fotografía coagula en lo visible es/era una identidad en construcción, temporal, frágil y dinámica, que la captación de la foto congeló en un instante y expuso a la mirada, pero que no se agota ni puede quedar totalmente expresada en esa coagulación. En tanto temporal, esa existencia o instante allí coagulado requiere de la interpretación de un receptor que la incluya en un relato, de

2 Stuar Hall (2003) usa el término 'sutura', en el sentido de adhesión o articulación temporaria, para referirse a la intersección de discursos y prácticas que quieren interpelar al sujeto colocándolo en determinado lugar social, y de procesos que producen subjetividad, que habilitan la voz del sujeto. 
un receptor que perciba su propia identidad como narrativa, en construcción, histórica y que, en consecuencia, pueda re-actualizar la propuesta que la fotografía encierra y el universo multívoco que ofrece (Leconte, 2011, p. 35).

Este ejercicio de desciframiento precisó la confluencia de varios tipos de relato en el nunca acabado sentido de la existencia temporal que la identidad comporta: "Interpretar una fotografía es interpretar una interpretación, por eso, requiere el diálogo y confrontación de relatos diversos, y que se favorezca la existencia de esta diversidad y ese diálogo" (Leconte, 2011, p. 35). La idea de vínculo es una idea fundamental para entender los procesos de identificación nacional. El vínculo es otra manera de nombrar la identidad. El vínculo convoca pertenencia, adscripción, ligazón moral. Llenar de sentido las redes de los vínculos y las pertenencias que los sujetos enuncian es a su vez reconocer los rasgos más importantes de su identificación nacional, una de sus aristas y más potente característica. Para Benedict Anderson,

se recurre a la nación para establecer un vínculo social entre individuos y clases basado en los valores, símbolos y tradiciones compartidos. La utilización de los símbolos (banderas, monedas, himnos, uniformes, monumentos y ceremonias) recuerda a los miembros el patrimonio y el parentesco cultural que comparten, y hace que se sientan fortalecidos y enaltecidos por un sentimiento de identidad y pertenencia común (Anderson, 1993, p. 15).

En ese sentido, ante la pregunta por los vínculos y adscripciones que tejen las nuevas generaciones en relación con su nación, los estudiantes ofrecieron respuestas variadas y multifacéticas. Más allá de la intensidad y el apasionamiento que mostraran hacia lo nacional o hacia alguno de sus elementos, predominaron tres tendencias: 1) la identificación con el territorio en tanto espacio de filiación cultural, bien desde un vínculo con lo geográfico, regional especialmente, o bien desde una admiración hacia expresiones dependientes de lo campesino, lo folclórico o lo ancestral; 2) la identificación con sentimientos que involucran comunión con proyectos colectivos que trascienden lo local, como aquellos que tienen que ver con el trabajo y la transformación por el bienestar de poblaciones marginales y la lucha por los derechos humanos de los connacionales menos favorecidos; y finalmente 3) un sentimiento de arraigo en grupos humanos específicos, como lo familiar, lo barrial y lo local. A continuación se presenta un cuadro que expresa las tendencias en uno y otro caso. 
La mayoría de relatos y de respuestas construidas por parte de los estudiantes universitarios participantes, fueron expresada en términos del amarre que sentían hacia el territorio, sobre todo regional, por distintas razones: por el origen de algunos jóvenes, por experiencias de contacto directo o por específicos efectos de admiración. Lo rural, las costumbres, las tradiciones, las expresiones culturales y la belleza de los paisajes fueron diferentes maneras de nombrar un vínculo con el territorio.

Veamos inicialmente algunos relatos visuales con sus respectivos comentarios:

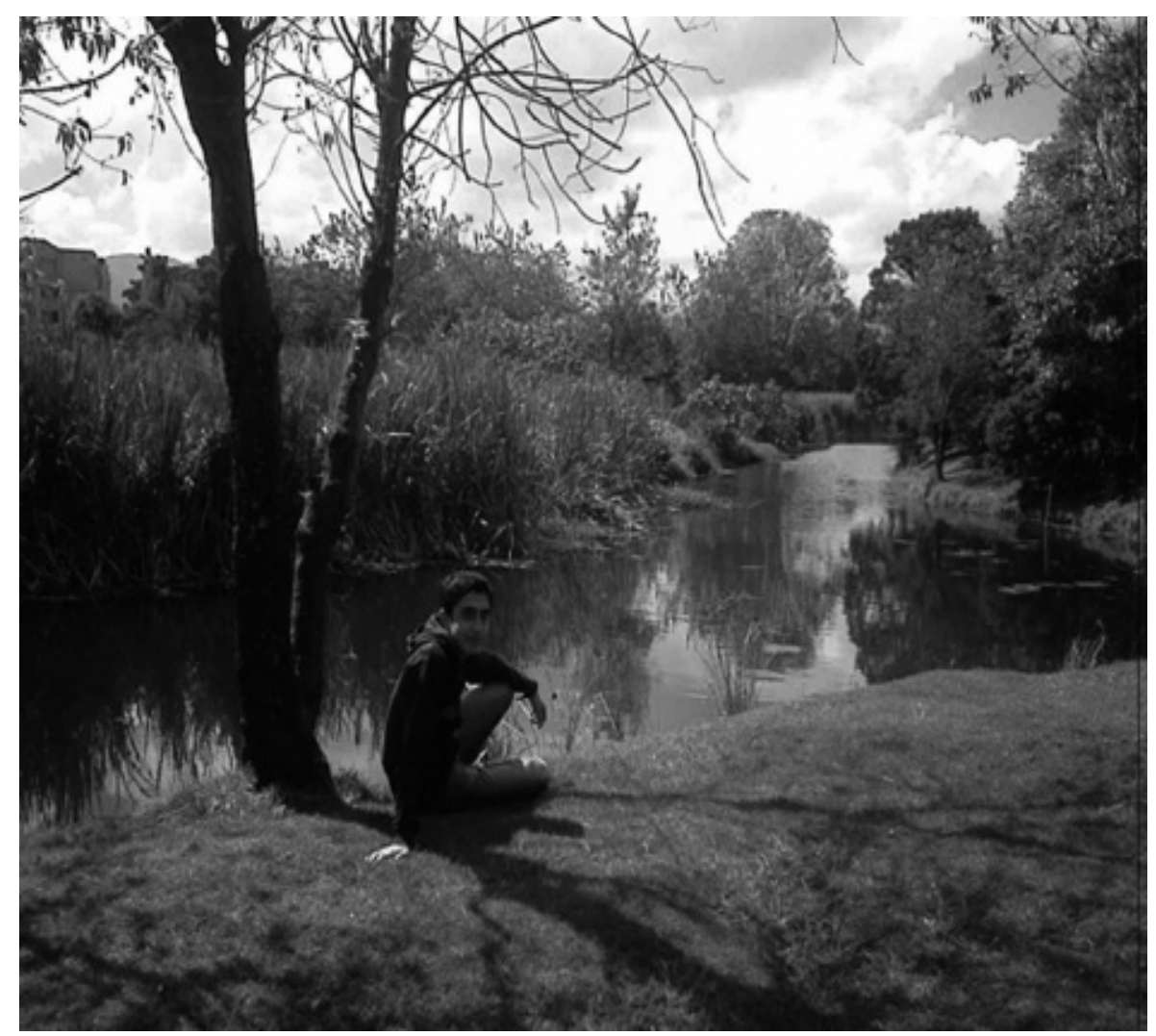

Mi condición como colombiano la puedo expresar en esta imagen en la que predomina lo natural y que de alguna manera se queda corto en comparación a todo lo que posee Colombia y que la hace distinguir de cualquier otro país. Esto se puede constatar con la riqueza hídrica que tiene Colombia y que nos abastece de una forma amplia (Armando - 1. ${ }^{\text {er }}$ semestre). 


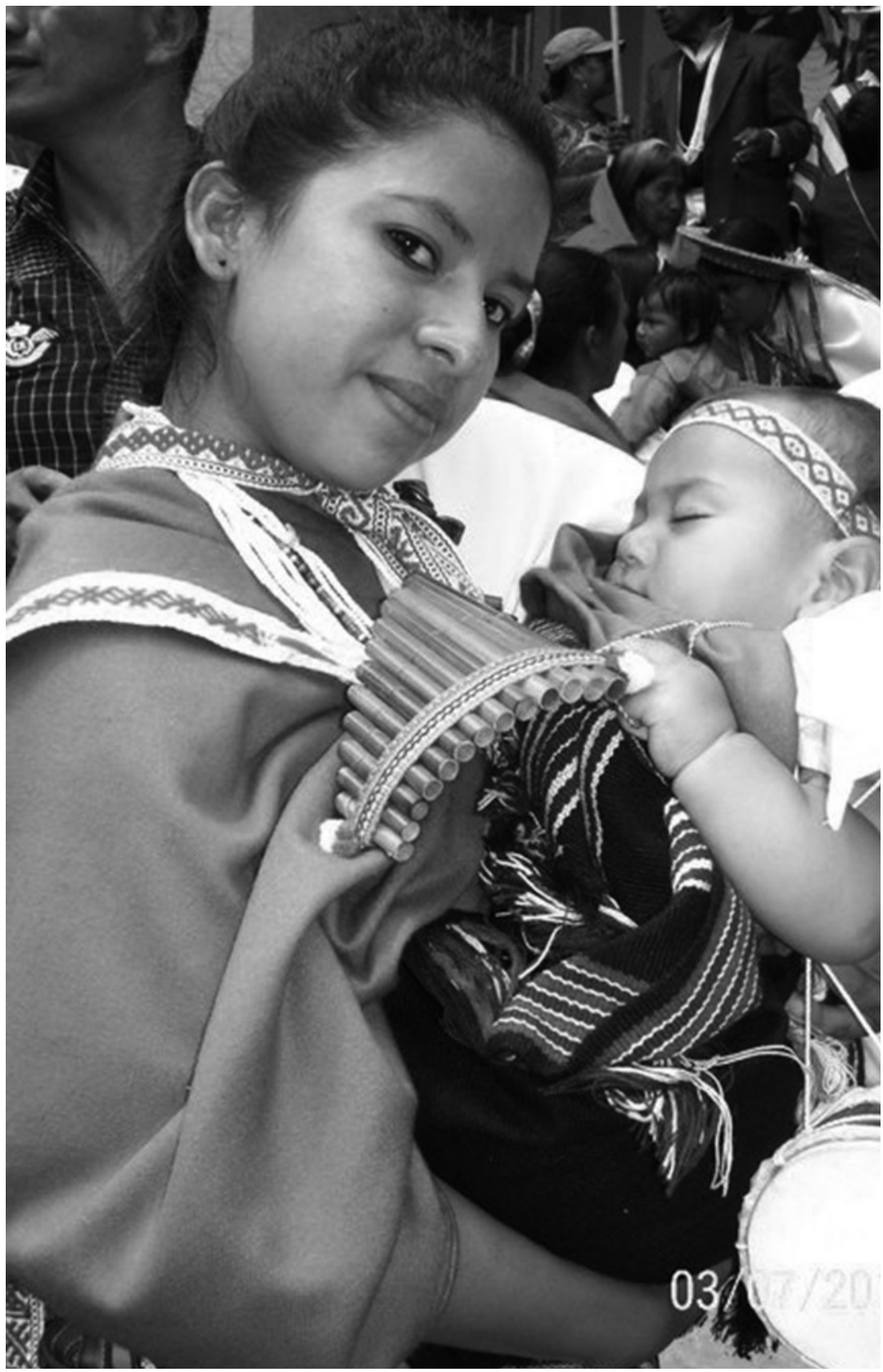

Mi condición como colombiano la puedo expresar en esta imagen en la que predomina lo natural y que de alguna manera se queda corto en comparación a todo lo que posee Colombia y que la hace distinguir de cualquier otro país. Esto se puede constatar con la riqueza hídrica que tiene Colombia y que nos abastece de una forma amplia (Armando - 1. ${ }^{\text {er }}$ semestre). 


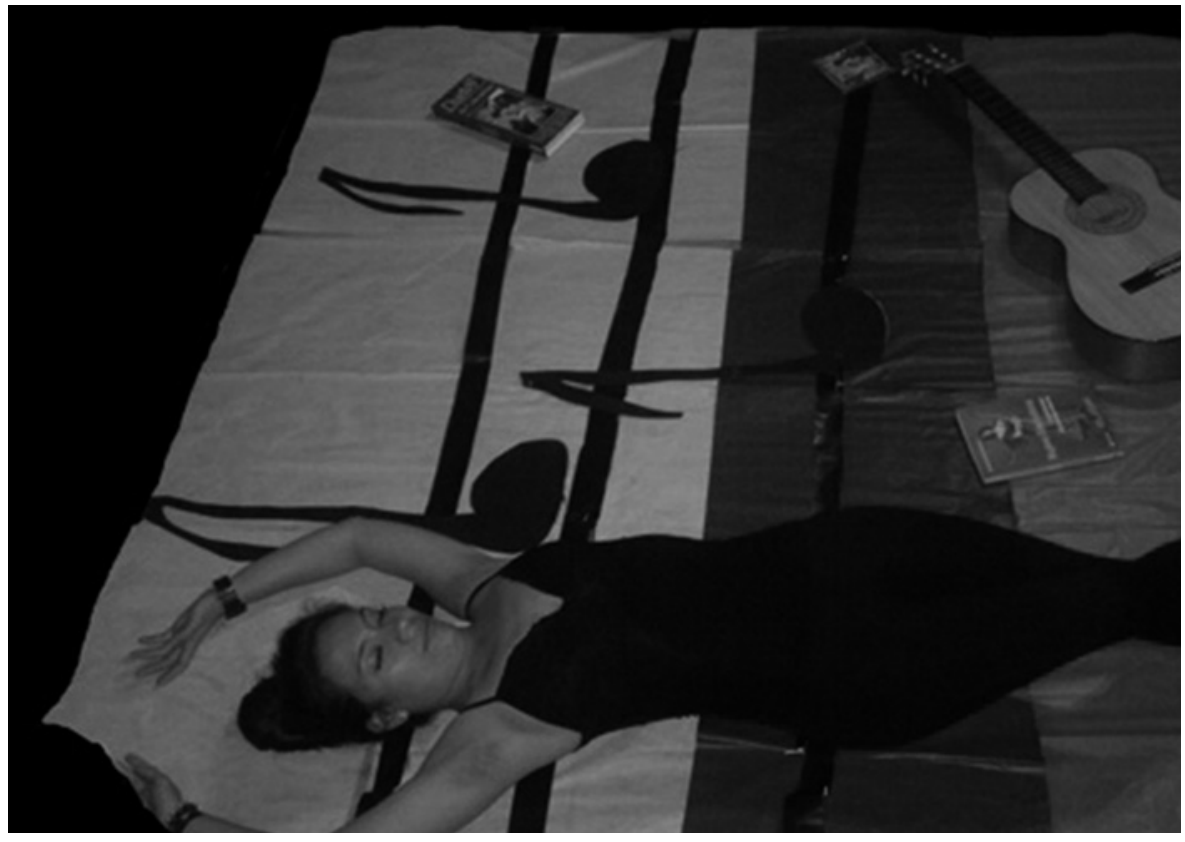

En mi fotografía quiero resaltar, la producción artística de nuestro país, y en este caso la importancia de la música en la consolidación de lo que en mi criterio significa la identidad nacional, ya que a través de artistas como Silva y Villalba, Garzón y Collazos, se relatan una serie de acontecimientos históricos, la época de la violencia, la riqueza cultural y física de diferentes regiones colombianas, de costumbres, modos y tradiciones que los colombianos hemos apropiado a lo largo de nuestra historia (Lorena $-7 .^{\circ}$ semestre). 


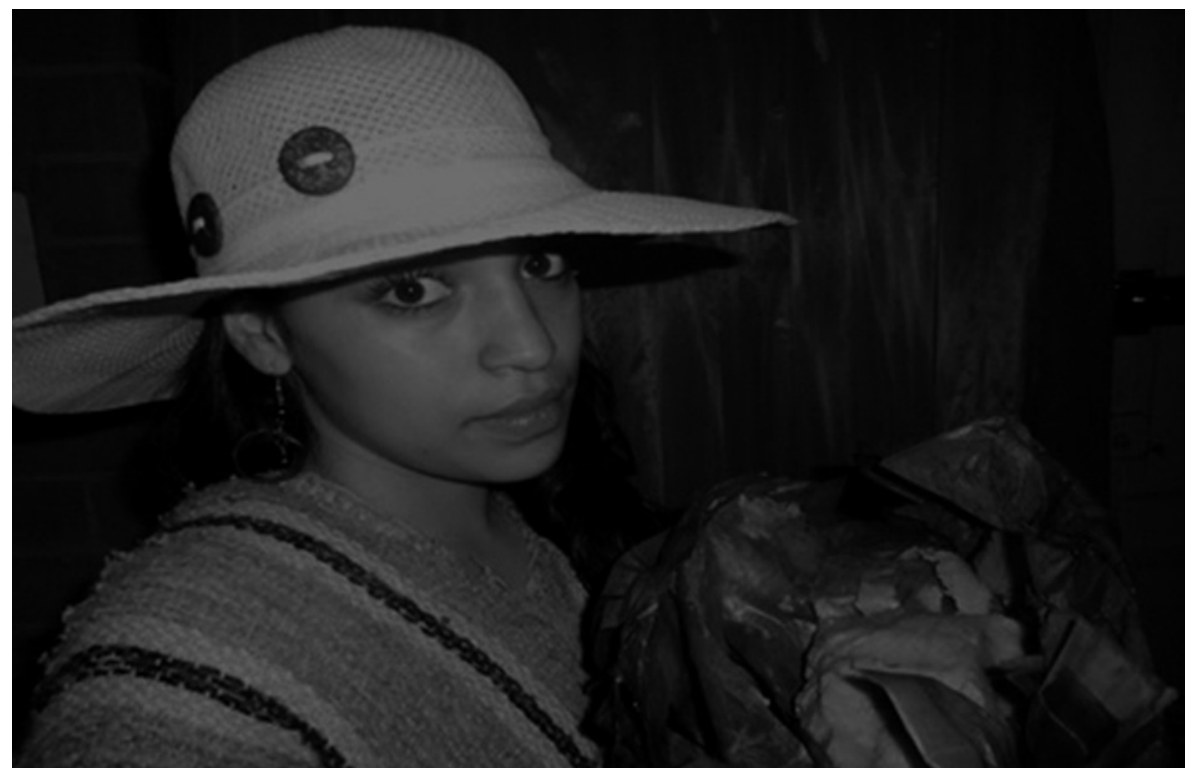

Esta foto representa un aspecto de lo que identifica a los colombianos, como lo es la comida y la vestimenta. Este es un aspecto que es propio de nuestra cultura y que nos identifica. La comida, al igual que la música, el idioma y el baile, son aspectos particulares de los colombianos. La comida colombiana es famosa en el mundo, se caracteriza por lo exótico y variado según cada región; por ejemplo, el tamal es una de las comidas que para mí es más representativa de la identidad colombian (Damary, 7. ${ }^{\circ}$ semestre). 
La imbricación del territorio y la cultura se hace patente en estos relatos que indican que la importancia y adscripción con el territorio pasa inevitablemente por el sentido que estos elementos adquieren para los sujetos y por las experiencias vitales que evocan. El territorio deja de ser un mero lugar físico para convertirse en un espacio que contiene músicas, comidas, productos y recuerdos afectivos. Las apelaciones al territorio, a propósito de la pregunta por la identidad nacional, se realizan en tanto lugar con significado cultural. El territorio adquiere importancia por las relaciones sociales que alberga o que suscita, más que por el contenido estético que despierta.

El territorio es una entidad dialéctica en el que confluyen intereses y sentidos relacionados con procesos sociales, de manera que las luchas por el territorio son disputas por espacios físicos y simbólicos productores de capital económico y, sobre todo, de capital social relevante para los grupos que los reivindican. La valoración del territorio que hacen los grupos se hace entonces por las experiencias que evoca y por los intereses que provoca (Llanos, 2010). El espacio, como el territorio, no es una categoría abstracta, es apropiado de acuerdo a las fuerzas sociales (Ortiz, 2004) y a las prácticas a las cuales se refiera. El territorio con el cual establecen identificación los jóvenes es aquel del que se sustraen recuerdos significativos y fuertes añoranzas. Para Gilberto Giménez (2005) "se entiende por territorio el espacio apropiado por un grupo social para asegurar su reproducción y la satisfacción de sus necesidades vitales, que pueden ser materiales o simbólicas" (Giménez, 2005, p. 9), es decir, el espacio se vuelve territorio al momento de ser asumido por los sujetos.

La importancia del territorio, con variados matices y destacando distintas dimensiones, es ampliamente reforzada en diferentes respuestas surgidas de las entrevistas:

Jennifer (1. ${ }^{\text {er }}$ semestre):

[...] Conocer la historia de Colombia, conocer las cosas que tiene cada región, la cultura de cada región, la música de cada región, las crónicas de cada región, todo eso son historias que forman esa identidad y esas vainas que lo hacen a uno colombiano. Digo qué orgullosa me siento cuando escucho el folclor y cosas de esas. Yo de mi parte tengo una fascinación con la percusión del Pacífico, entonces cuando yo escucho digo: "qué chévere, Colombia tiene esto". Y me da gusto poder escuchar eso y pertenecer a la historia de eso. Puede que no descienda directamente de allí, pero tengo alguna conexión, tal vez remota, con ese pasado. 
Doniben ( $7 .^{\circ}$ semestre):

[...] Es un poco con el grupo de música andina [al que pertenezcol, que no es solamente música andina sino que desde antes había unas raíces de música colombiana, entonces reinterpretar a Silva y Villalba, Garzón y Collazos. De alguna u otra manera por la misma música es que he sentido ese acercamiento culturalmente. Entonces, es como esa tradición, como que se manifiesta en esos momentos en que ensayamos, entonces, en un pasado cercano es esa relación con la música que me siento a cantar El barcino o Soy colombiano, por ejemplo, eso como que de alguna manera me hace sentir orgulloso.

Lizeth $\left(7 .^{\circ}\right.$ semestre):

[...] Digamos con mi identidad regional, buena parte, digamos, el tabaco santandereano para mí es algo, una experiencia maravillosa. Actualmente mi familia vive en un pueblo tabacalero llamado Piedecuesta, Santander, y para mí la experiencia del tabaco también es algo no solamente de sensaciones, sino también de una forma de vida. Entonces, el tabaco, el café y, no sé, montar a caballo, también me parece muy bacano ${ }^{3}$. Me parece como de las cosas más chéveres de la cultura santandereana, aspectos que han influido en mí, en mi infancia y en mi juventud, y también de las cosas que yo me gozo en lo que es Colombia. Y también me gusta el paseo de olla. En mi familia todavía tenemos la tradición de paseo de olla, además, porque la región tiene aún ríos limpios donde uno puede ir a bañarse y hacer un sancocho al lado del río, coger las cosas y volver a la casa citadina y estar normal, estar en un mismo lugar compartiendo cosas que parecieran del campo, pero también en la ciudad. Pues para mí eso es como lo que más ha marcado como mi forma de pensar, de entender el mundo y es que mis papás hayan sido dos campesinos que se encuentran en Bucaramanga, se enamoran y se casan. Y yo haya sido una chica criada en la ciudad pero con toda la costumbre campesina. Es como una hibridación cultural de la cual soy heredera.

En los relatos visuales y escriturales producidos por los jóvenes y en particular en los anteriores ejemplos traídos a colación, afloran varios elementos que vale la pena destacar. En primer lugar, Ilama la atención la fuerza puesta en lo regional, que en lugar de fraccionar lo nacional, lo sitúa, lo acentúa, lo concreta. Parece que en la condición de la comunidad imaginada (Anderson, 1993) pesan más los vínculos regionales que han dependido de las condiciones biográficas de existencia

3 Agradable. 
o del profundo gusto por las expresiones tradicionales, tal y como lo narran estos chicos.

El territorio se enarbola como eje de identificación porque es verde, rico, diverso, y porque de sus raíces brotan expresiones culturales consideradas hermosas, que enaltecen los sentimientos de pertenencia. Tanto en el paisaje agradable a la vista, como en la música que excita el oído, se tramita un vínculo sensorial que conecta existencialmente a un lugar de pertenencia y afecto, a un pasado reciente que se percibe como $\operatorname{arcano}^{4}$, a unas costumbres y tradiciones locales que representan lo que somos.

Sin embargo, al igual que los llamados que se hacen desde imaginarios de la nación esencialistas (Hobsbawm, 1994), este vínculo con lo regional es tramitado con la responsabilidad de continuar con un legado venido desde los ancestros o desde un pasado honorable que se tiene el deber de perpetuar. Hay una herencia que transmitir y un territorio que cuidar, de manera que el procedimiento para responder a la pregunta por la identidad se resuelve, para estos jóvenes, por la vía de las raíces (Martín-Barbero, 2002) y no tanto del proyecto a construir. Según esta versión, es en el tiempo pretérito que se encuentran los insumos básicos para forjar la identidad. Bajo esta perspectiva, las costumbres, el folclor, las expresiones culturales regionales tradicionales, no solo son los aspectos que definen lo nacional, sino los que ameritan identificación y fidelidad por parte de estos estudiantes universitarios.

Además, hay que resaltar que buena parte de esta identificación con lo regional, su territorio y sus expresiones no se hace necesariamente contra o en sustitución de lo nacional, más bien lo concreta, lo objetiviza. Frases como "me siento orgullosa", "soy heredera", "tengo alguna conexión" son recursos argumentativos que esgrimen estos jóvenes en el contexto de una defensa y valoración de la región para destacar sus supuestas características únicas y la responsabilidad personal de continuar o reproducir un legado, o en otras palabras, de preservar una tradición (Hobsbawm \& Ranger, 1983). Cuando eventualmente la identidad regional se opone a la nacional se hace básicamente desde una impugnación al Estado, que no ha hecho presencia en muchas regiones del país o, en el caso de hacerlo, ha sido para atropellar a los pobladores, vulnerar sus derechos y desconocer las culturas parti-

4 El dueto Darío Garzón y Eduardo Collazos grabó en 1947 su primer disco, aunque fue en los cincuenta que se dieron a conocer a nivel nacional. El dueto de Rodrigo Silva y Álvaro Villalba grabó su primer disco en 1970, Ilamado Viejo Tolima, con canciones como "Al Sur", "Llano grande", "Soñar contigo", "Pescador, lucero y río" y "Oropel". 
culares. Dice Diana, exhibiendo los atuendos y colores propios de su cultura indígena: "Al hacer parte de esta comunidad uno se da cuenta de los grandes atropellos que ofrece el Estado en contra de nosotros, la manera como utilizan a las comunidades indígenas". Por su parte, en la fotografía de Lorena el elemento nacional (la bandera) es el colchón que sirve de base para que lo regional (notas del pentagrama, cartillas, instrumentos musicales y ella misma) resalte en medio de la performance que ha montado. La identidad con el territorio regional mantiene una tensión constante con la identidad nacional que se resuelve de distintas formas dependiendo de los sujetos y los contextos. La identificación con la nación marca, al tiempo, una enorme distancia con el Estado, al punto de ser impugnado de manera permanente, porque aunque teóricamente puedan estar conectados o confundirse en algunos momentos, experiencialmente no lo están. Así la nación es un concepto identitario, mientras que el Estado es un ámbito lleno de mediaciones institucionales y formales.

El paisaje es una construcción social, cuya función "es servir como símbolo metonímico del territorio no visible en su totalidad, según el conocido mecanismo retórico de la parte por el todo" (Giménez, 2005, p. 15). El paisaje es la ventana del territorio que se usa para destacar la particularidad y unicidad del mismo. El paisaje también funge como impronta indeleble de lo nacional. "Como espacio concreto cargado de símbolos y connotaciones valorativas, el paisaje funciona frecuentemente como referente privilegiado de la identidad socio-territorial" (Giménez, 2005, p. 15). No en vano muchas de las fotografías escogidas por los estudiantes participantes tuvieron como escenario o primer plano paisajes del territorio nacional.

En otro sentido, María Teresa Uribe (2001) habla de unos destiempos entre la realidad histórica y cultural, entre la construcción del Estado y la construcción de la nación, en este movimiento la presencia de lo regional y sus lógicas en Colombia ha sido un elemento clave en la construcción de nación, fundamentalmente por la histórica ausencia institucional del Estado.

Lo que no significa que el Estado carezca de presencia física; de hecho está y no solo como pura potencia a través de las fuerzas militares sino también mediante su rama ejecutiva y judicial, a más de algunas entidades descentralizadas que desarrollan la política social del gobierno; mas la presencia física del Estado no quiere decir que los pobladores se enmarquen en relaciones sociales institucionalizadas, que se acojan a ese poder formal así sea pasivamente o por costumbre; la ausencia alude más bien a 
que los referentes simbólicos de la sociedad mayor no operan, no funcionan y los pobladores asumen su vida a través de referentes diferentes, de prácticas sociales y sistemas de cohesión que están aún por estudiar (Uribe, 2001, p. 24).

Enfatizando esta idea de María Teresa Uribe, podríamos decir que las formas de interacción local y regional, los referentes colectivos territoriales, han tenido más peso que los discursos venidos del Estado, en tanto aglutinadores simbólicos de lo nacional, o por lo menos han sido sus mediadores legítimos. En esta misma línea argumental, según los relatos de los estudiantes, parece que mientras el Estado requiere de legitimidad dada la precariedad de su presencia, la nación no, debido al carácter naturalizador de sus experiencias.

Paradójicamente, como la identidad nacional tiene que ver con el Estado, es posible afirmar que los vínculos regionales que los estudiantes universitarios exhiben reproducen, en parte, las lógicas diferenciadoras sobre lo nacional que el poder estatal-institucional ha fabricado, máxime cuando lo político es bloqueado en las alusiones a las manifestaciones tradicionales (llámense folclóricas o populares), que enfatizan en un distanciamiento condescendiente o en un purismo que las encumbra como piezas auténticas, incontaminadas o reflejos verdaderos de lo que supuestamente somos.

Este hallazgo se acerca a lo encontrado por Índrid Bolívar (2006), quien preocupada por rastrear la manera como la dominación política produce diferencias culturales-regionales, muestra cómo en algunos departamentos de Colombia la formación del Estado y la construcción de identidades regionales han sido procesos que van de la mano. Para esta investigadora las expresiones culturales son formas de clasificar las relaciones sociales dentro de un orden político, es decir, en el marco de la articulación entre lo político y lo cultural, "una identidad solo puede aparecer como tal cuando echa mano de los recursos que han sido objetivados en y por la acción estatal" (Bolívar, 2006, p. 39), de tal suerte que la existencia de identidades regionales no se hace contra la identidad nacional, sino que es una de sus condiciones o posibilidades de existencia.

Esta tesis no solo ayuda a resolver la aparente tensión que se anunciaba antes, sino que pone en evidencia las lógicas políticas impulsadas por el Estado que pretenden naturalizar lo cultural atándolo exclusivamente a expresiones atávicas y limitando de esta forma comprensiones del presente que problematicen las fuerzas mediante las cuales los sujetos configuran su propia identidad. 
El rechazo al Estado y el acogimiento de la nación que se explicó atrás concuerda parcialmente con lo hallado por Miriam Kriger (2010) en un estudio con jóvenes argentinos, en el contexto de los levantamientos y estallidos sociales luego de la crisis de 2001. La autora encontró que, a la vez que se daba el rechazo de los estudiantes hacia la política profesional (proselitista y gobiernista), sucedía una identificación positiva con la nación y su historia, y un deseo de participar y conjuntar esfuerzos hacia un futuro común. Para la autora la comprensión política pasa inevitablemente por la formación histórica. Si la primera no se da, la identidad nacional compensa ese vacío y "se produce entonces una hipertrofia identitaria que intenta saldar el déficit cognitivo y seguir adelante, aunque no puede hacerlo en la clave de la reconstrucción política sino de la refundación nacional" (Kriger, 2010, p. 215).

Pese a que el presente estudio no alcanza a vislumbrar el mismo nivel de amputación de la potencia política en función de un ideal de ciudadanía social ampliada, que la autora destaca, alerta sobre la manera como los sentimientos nacionales pueden obstruir la comprensión del presente y por ende las posibilidades de intervención política acertada en este tiempo. Esta distancia es nombrada por Alexander Ruiz (2011) como la brecha entre la nación aprendida y la nación vivida, en el entendido de que "cuando los jóvenes se refieren a lo que su propia nación les ofrece y a lo que directamente les está negando realmente se están refiriendo al Estado nación con el que construyen una relación más experiencial que identitaria" (Ruiz, 2011, p. 222). Para este investigador los imaginarios que construyen los jóvenes sobre la nación propia pasan por sentimientos morales que con frecuencia se sobreponen a la comprensión crítica de la historia, imponiendo versiones románticas e ingenuas del pasado, y suscitan fuertes apegos, a la vez que se desprecia la política actual por mezquina y corrupta. Para los jóvenes con los que trabajó Ruiz, como para los del presente estudio, los procesos de identificación con la nación se hallan limitados a la idea de defensa y conservación y menos a la de proyecto, dimensión que será abordada más adelante.

Esta identificación con lo territorial aquí encontrada contrasta con lo esbozado por Smith (1997), para quien este tipo de identidad, denominada identidad primaria, es más propia de la premodernidad, que en el caso europeo ha sido incapaz de movilizar a sus habitantes bajo sus banderas localistas, y que junto a la identidad étnica, la socioeconómica y la de género, no tienen tanta capacidad de aglutinamiento como la identidad nacional. En efecto, para este autor, existe un vínculo histórico entre la idea de Estado y de territorio, que es la caracterís- 
tica más importante de la nación, pero esta acepción justamente debe trascender más allá de lo territorial, pues la nación se perfila como un gran territorio que absorbe otros territorios más pequeños para imponer nuevos límites y valores en los pobladores que antes se guiaban por sentimientos locales. La importancia dada al territorio nacional permite a los individuos disponer de "centros sagrados, objeto de peregrinaje espiritual e histórico, que ponen de manifiesto el carácter único de la 'geografía moral' de su nación" (Smith, 1997, p. 14). Estas características, en el caso de los imaginarios sociales esbozados por los estudiantes universitarios, se mantienen para lo regional, lo que se traduce en que las identificaciones con el territorio no se contraponen necesariamente con lo nacional, sino que lo configuran, lo patentizan.

Como toda identidad es un ejercicio de etiquetamiento social (Appiah, 2007) es posible también colegir que las identidades locales y domésticas aquí acotadas han contado con más mecanismos de persuasión que la identidad nacional. La identidad local funge como marca de reconocimiento, bien como apropiación de la propaganda realizada en los últimos lustros por parte de las administraciones de las grandes ciudades, bien como recurso de afirmación frente al legendario abandono del Estado, en el caso de poblaciones apartadas con graves dificultades para resolver sus necesidades básicas. Recordemos que la etiqueta cumple una función social al "desempeña[r] un papel en la configuración de la manera en que el agente toma decisiones acerca de cómo llevar una vida, es decir, en el proceso de construcción de la identidad propia" (Appiah, 2007, p. 117).

Mientras la tierra, la geografía, el paisaje, los lugares, son objeto de referencia identitaria, o mejor sería decir, nos permiten configurar topofilias, la idea de territorio llega a ser mucho más vinculante en términos identitarios, pues refiere a prácticas (por ello la referencia obligada a la cultura) y la mayoría de gente se identifica realmente es con prácticas (ancestrales, epocales, generacionales). La identificación con la nación propia es una forma de identificación social en la medida en que nos permite sentirnos parte de formas de vida que suponemos compartidas, es decir, de prácticas sociales (culturalmente acendradas: costumbres, tradiciones, expresiones, o culturalmente innovadoras: impugnaciones, rebeldía, expresiones contestatarias, etc.). Los lugares nos generan nostalgia porque están asociados a experiencias, de ahí la relación entre tierra y territorio o entre un paisaje y la imaginación que llena ese paisaje de memorias. 
En suma, la dimensión política se revela como un componente clave de la identidad nacional, en el caso de la identificación con el territorio, al materializar la identidad nacional, al esencializar unos componentes de la cultura y al establecer una distancia crítica con un Estado inoperante o ausente. Sin embargo, tal relación con lo político fue mucho más explícita en otros relatos de estudiantes universitarios, en dirección a entender la identificación nacional como el compromiso personal con proyectos de carácter transformador, aspecto que se profundizará en el siguiente apartado.

\section{La identificación con proyectos colectivos}

La política entendida como las representaciones y las prácticas sobre el orden social deseado (Lechner, 2002) proporciona las claves de interpretación que posibilitan a las personas entender el funcionamiento de la sociedad y las herramientas para intervenir sobre ella.

Una tarea primordial de la actividad política consiste en producir y reproducir las representaciones simbólicas mediante las cuales estructuramos y ordenamos 'la sociedad', incluyendo la 'puesta en escena' de la propia política. Ella actúa, pues, a un doble nivel: decisiones concretas y representaciones simbólicas. Es a través de tales representaciones que la política delimita no solo el campo de lo que está a disposición de la voluntad política, sino igualmente el campo de lo posible, lo factible, lo deseable. En fin, circunscribe lo que cabe esperar de la política (Lechner, 2002, p. 25).

La política tiene que ver con los mecanismos ideados por los grupos para perpetuar o transformar la sociedad, por ello es un campo en disputa. La identidad nacional es una categoría político-cultural en tanto se sirve de unos dispositivos culturales ligados a la red de significados y sentidos sociales históricamente configurados, para proyectar una filiación hacia el orden establecido o para trascenderlo. Como se vio en el anterior apartado, tales marcas políticas no son siempre explícitas, en otros casos sí lo son, como cuando los sujetos interpelados por su identidad nacional enarbolan una adscripción a esfuerzos cuyo fin es la modificación de la estructura social vigente.

En el presente apartado se aborda el conjunto de ideas y proyectos colectivos que, según el criterio de los estudiantes participantes, tienen que ver con la identidad nacional y que, en tanto propuestas políticas, pujan por darle un sentido de transformación y cualificación social a la nación. Este ítem revela el carácter explícitamente político de la 
identidad nacional, en el sentido de articular sus posicionamientos al ordenamiento social y de exhibir claves interpretativas sobre los grupos y las lógicas que pujan por el poder en el país.

Existe un grupo de relatos que informan sobre un imaginario social, en el que la identificación nacional y la esencia de la nación se juega en proyectos alternativos que escapan a las estrategias de vinculación provenientes del Estado. Veamos algunas imágenes y testimonios que ilustran esta posición:

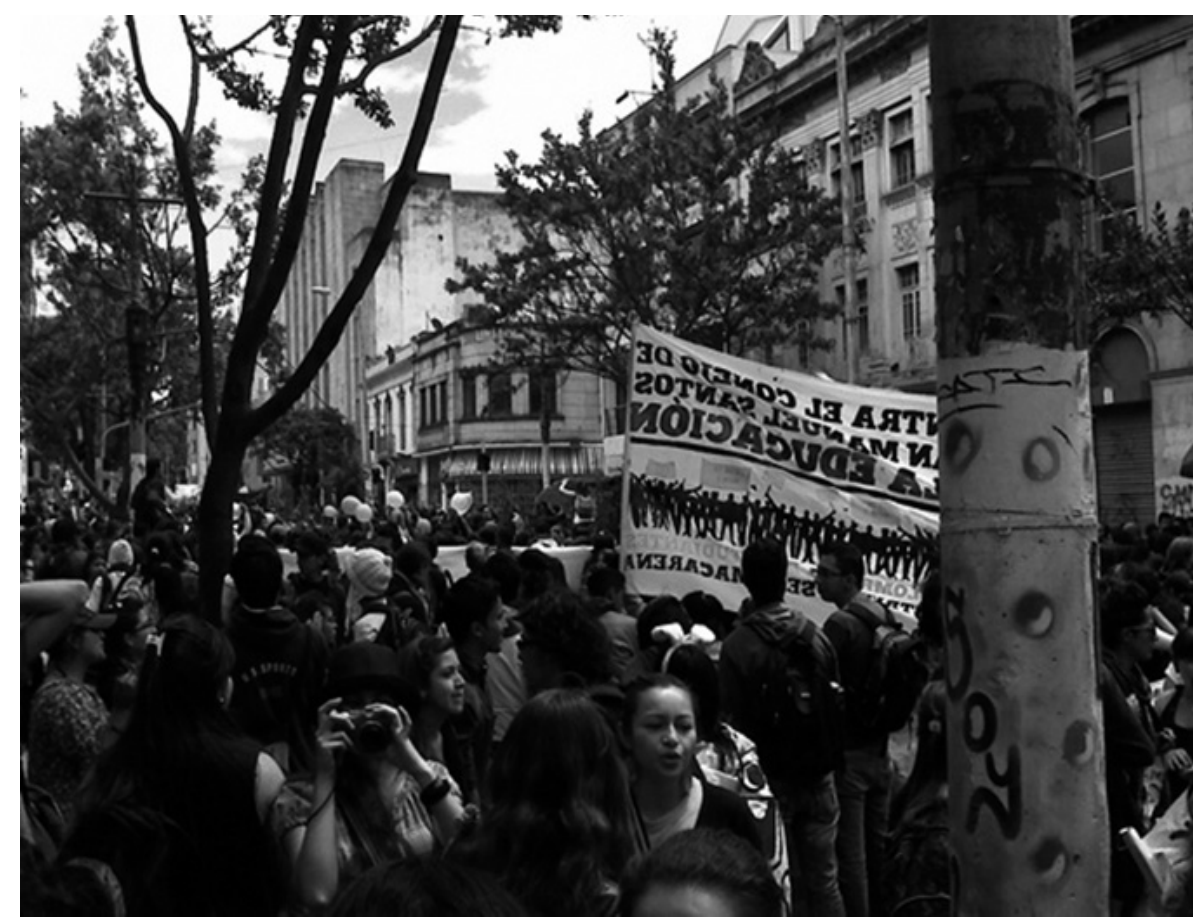

Colombia para mí son las personas que sueñan, que imaginan, pero que más que eso, que hacen. Su revolución no se trata de una gran guerra, sino de sacar lo mejor de sí mismos y dárselo a los demás. Los revolucionarios que no se quedan callados, no son cómplices de la injusticia, se movilizan, proyectan y ven una Colombia diferente. No una socialista, no una capitalista, comunista o marxista, solo un territorio justo donde los ancianos no tengan que trabajar en las calles, donde los niños tengan educación. Un país donde dejemos nuestro individualismo y pensemos en el otro, no como competencia, sino como compañero (Felipe S. -1 . ${ }^{\text {er }}$ semestre). 


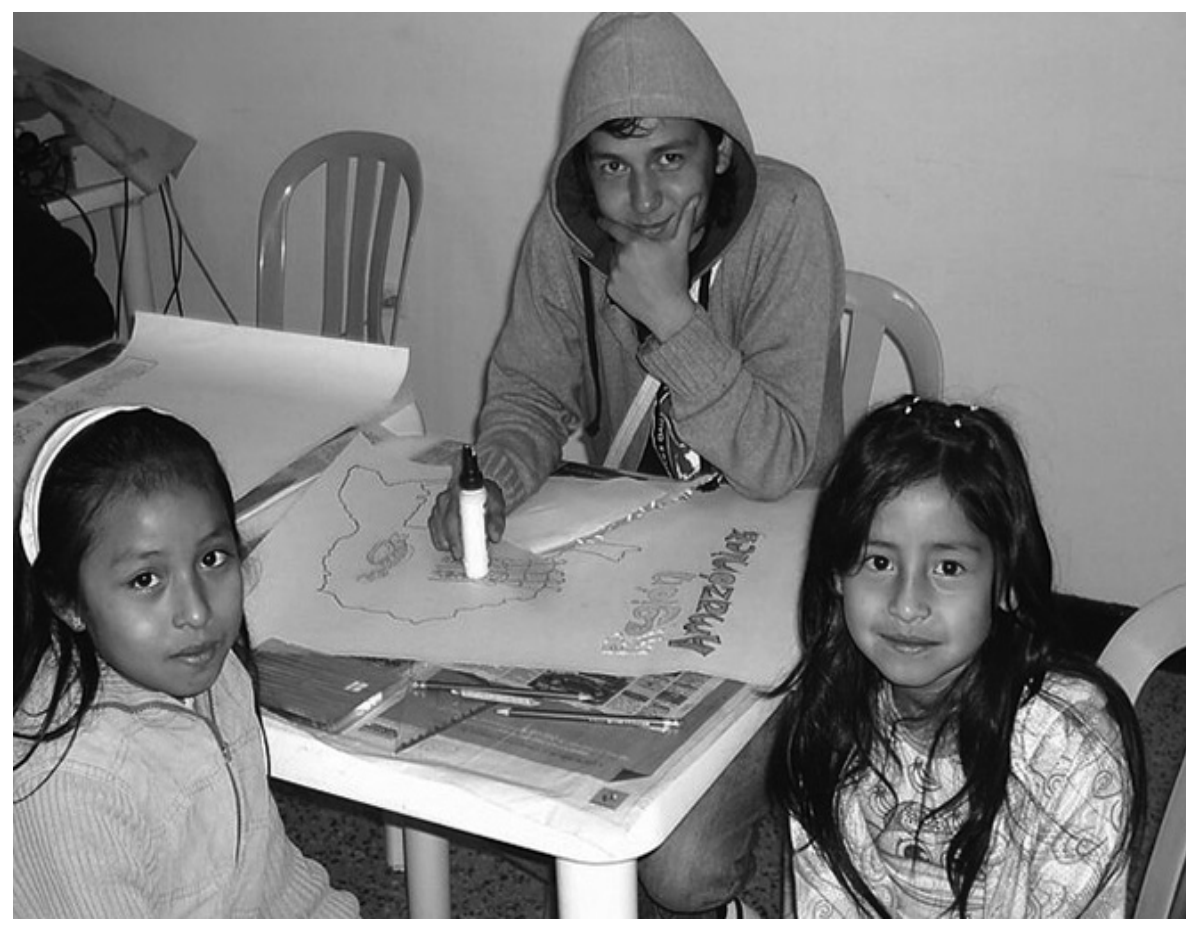

En esta foto represento mi condición de colombiano, pues considero firmemente que es a través del trabajo popular, básicamente con niños, que es donde me desenvuelvo actualmente, donde uno puede contribuir a la formación de un pensamiento crítico, hacia cada una de las dinámicas que se viven a diario en nuestro país y de esta manera generar una posición más propositiva hacia el bienestar, y generar posibles soluciones de cada una de las conjeturas [sic] que se viven socialmente en nuestra sociedad (José - 1. er $^{\text {semestre). }}$ 


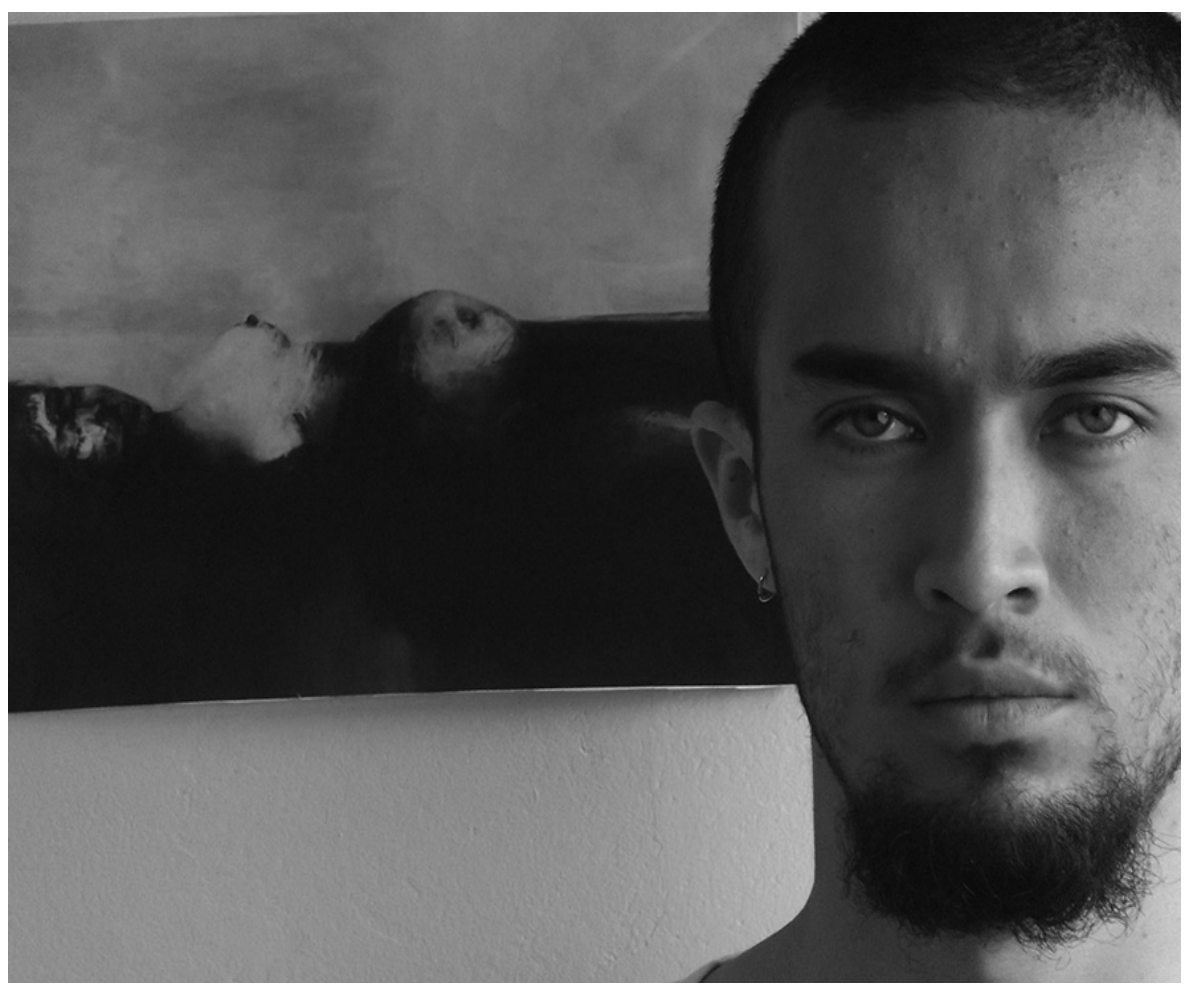

En este autorretrato decidí, para identificarme como colombiano, ubicarme junto a la obra del artista Fernando Obregón Ilamada La Violencia. Nuestra historia nacional ha tenido como constante la violencia, pero no es mi intención que se interprete aquí al colombiano promedio como esencialmente violento. Considero, a su vez, que este cuadro ha sido la representación más adecuada que se ha hecho de nosotros mismos como colombianos. La imagen de una mujer embarazada y golpeada brutalmente expresa para mí a esta nación y a su historia, nos muestra lo que fue y ha acompañado a nuestro pasado, el presente en el que no ha cesado la muerte y el olvido, y el futuro que yo no deseo sino que actúo por no tener. Interpreto que este cuadro encaja en todo modo de vida de este país, espacio temporalmente complejo, e invoca a generar una representación renovada y consensuada, a conocernos mutuamente y crear lazos, a fundamentar nuestra existencia desde lo más profundo y olvidado de nuestra sociedad para deslegitimar la violencia y su imposición en nuestra vida cotidiana (Camilo $-7 .^{\circ}$ semestre). 


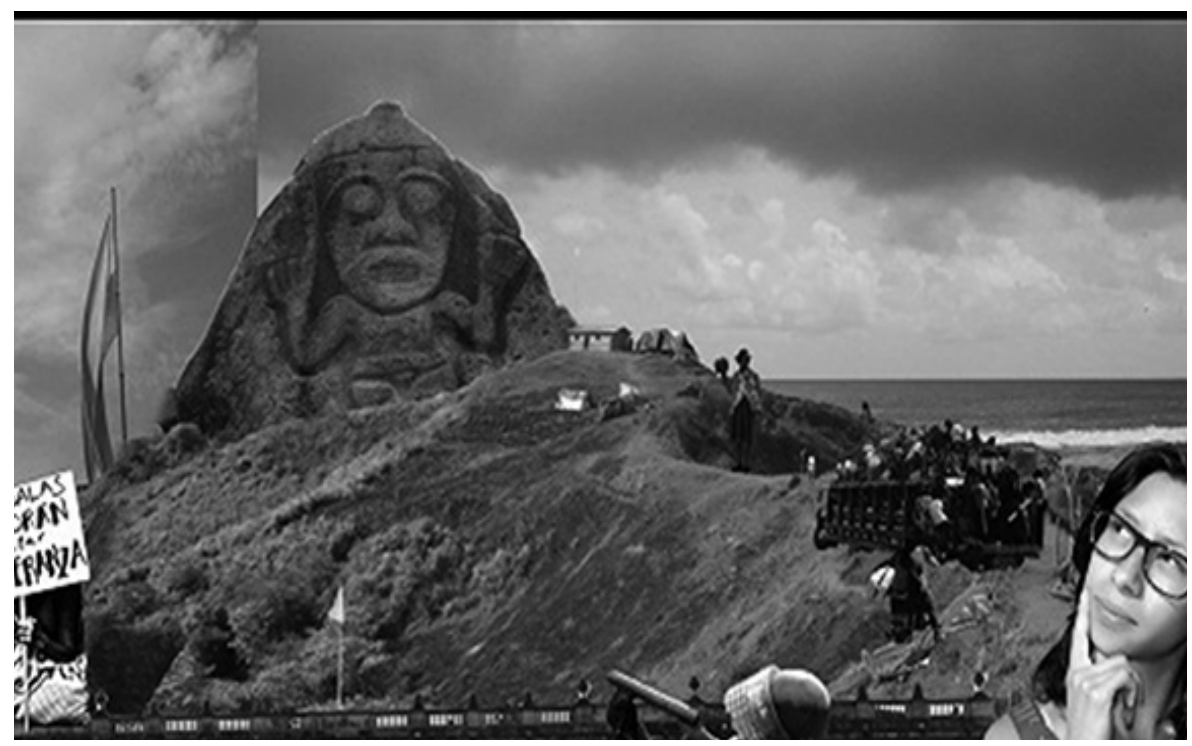

La foto recoge varios parajes de nuestro país. Se encuentra "La Chaquira" de San Agustín, los caminos del Cauca minados por el ejército, las murallas de Cartagena. Son espacios que he pisado con mis pies, que me han dejado el recuerdo vivo del territorio, sobre todo un recuerdo vivo de resistencia. Colombia no solo es pasión, pasión en reinados de belleza y fútbol, no es solo cocaína, armas y sexo. Es también territorio, caminos forjados con pala y pica a manos de los campesinos, los indígenas, los afros, cultivadores de papa, yuca y cultura, de resistencia. Son estos caminos llenos de riquezas de recursos naturales, que quieren ser apropiados con terror. El Gobierno nacional expropia el territorio que es de los colombianos y las colombianas para ser dado a multinacionales y extranjeros, a cambio nos quedamos con el desplazamiento, el hambre, la injusticia (Daniela $-7 .^{\circ}$ semestre). 
Veamos ahora algunos fragmentos seleccionados de las entrevistas en profundidad que se relacionan con este mismo componente:

Jennifer (1. ${ }^{\text {er }}$ semestre):

Al decir Colombia, lo que se me viene a la cabeza suele ser, más que todo, el trabajador de la tierra, el campesino, también pienso en amas de casa y en constructores, personas que hacen el país desde abajo, la gente, los trabajadores, son lo primero que se me viene cuando dicen Colombia, la lucha de la gente.

Julián (7. ${ }^{\circ}$ semestre):

Me identificaría con Jaime Garzón, por su irreverencia y porque era un colombiano que se salía del promedio; sabía de las problemáticas que tenía este país y se la pasaba denunciándolas, pero también reconocía el aislamiento que tuvo el país, cada región, el individualismo: como que yo aprovecho para mí y los demás que se jodan. Entonces, como que eso es bastante significativo y me Ilama mucho la atención Jaime Garzón. Yo no alcancé a verlo, no lo recuerdo mucho, sino los videos que quedan por ahí del señor.

Rubén (7. ${ }^{\circ}$ semestre):

Entonces, ¿qué me amarra a mí a este país? Yo creo que las potencialidades que tiene y lo que este país pueda llegar a ser, mas no lo que es este país realmente. Más hacia el futuro, más lo que yo creo que pueda llegar a ser. [Ser colombiano] es también la representación de un país, el hecho de procurar trabajar con esa población o hacer algo por esa población, o con esa población, más bien. Trabajar por el bienestar y por otra situación social en pro de la gente. Para mí eso es ser colombiano, porque, como dije, me parece que lo que conforma Colombia es la gente, lo que conforma un lugar, una organización, lo que conforma cualquier espacio y cualquier institución, y cualquier espacio es la gente; entonces, a partir de ahí baso mi concepto de colombianidad.

Los proyectos, los buenos propósitos, los anhelos, las ideas de transformación social que favorezcan a todos, especialmente a los históricamente excluidos, articulan la relación de estos jóvenes con su propia nación. Llama la atención que la idea de Colombia se esgrime en un contexto político muy marcado, en el caso de relatos visuales de Felipe y José, con la intención de lucha e intervención ("Colombia para mí son las personas que sueñan, que imaginan, pero que más que eso, que hacen"; "es a través del trabajo popular [...] donde uno puede contribuir a la formación de un pensamiento crítico"), y adicionalmente, en el caso de Camilo y Daniela, por la violencia ("la imagen de una 
mujer embarazada y golpeada brutalmente expresa para mí a esta nación"; "caminos llenos de riquezas de recursos naturales, que quieren ser apropiados con terror").

Es evidente la simpatía de muchos de estos jóvenes con militancias políticas que propenden por el cambio social. Probablemente por la participación en movimientos sociales como se observa en las imágenes que hacen alusión a protestas públicas, vinculadas a experiencias propias, a su proceso formativo, en el contexto de un programa de licenciatura en ciencias sociales en una universidad pública o por otras circunstancias.

Como aflora en los relatos de estos estudiantes, dar cuenta de la identidad nacional es exhibir los opciones políticas que los sujetos portan: "los revolucionarios que no se quedan callados, no son cómplices de la injusticia, se movilizan, proyectan y ven una Colombia diferente" dice Felipe. Esta politización del discurso que rescata "la lucha de la gente" según Jennifer, inscribe las apuestas personales en un trazado social que trasciende el bienestar personal y postula el anhelo de trabajar por un orden deseado (Lechner, 2002). Los relatos visuales son explícitos. No hay interés por obviar la relación entre identidad y política. Según Bolívar (2006), la diferenciación impuesta entre identidades y política que el poder oculta funciona precisamente al naturalizar formas de ser que han sido construidas en una interacción jerarquizada, ocultamiento que se rompe, en los presentes relatos, al hacer manifiestas las posiciones personales y al denunciar los mecanismos para perpetuar la violencia y la injusticia, como lo ilustra el caso del cuadro sobre la violencia que está en el trasfondo de la foto de Camilo o del grupo de policías antimotines que ubicó Daniela frente al Congreso de la República.

Como se mencionó en el apartado teórico, se ha insistido en aludir a la violencia como si se tratara de una impronta de la nación, a la única manera como fue históricamente conformada, y a la forma de negociar regionalmente la presencia del Estado (González, 2004a), también como rasgo iniciático de la identidad nacional (Patiño, 2005). Sin embargo, la violencia es invocada por los jóvenes como tragedia a superar, como herencia nefasta que no se esconde, pero que tampoco se desea.

Enfatizamos el hecho de que aquí la nación se inscribe en un proyecto colectivo, en la medida que expresa cercanía con propuestas de transformación social y de acción solidaria, y a la vez, porque se marca distancia con una situación estructural de injusticia históricamente padecida. 
La identidad nacional que exhiben estos jóvenes devela su cariz político al poner de manifiesto su vinculación en las potenciales o reales iniciativas del cambio perseguido. Al respecto se ponen el juego estrategias identitarias (Giménez, 2002), en el sentido de que la identidad aparece como un medio para alcanzar un fin, pero no en una línea instrumental, es decir, para el caso que nos convoca, la apelación a la identificación nacional sirve para enarbolar una posición política que se imbrica con un plan colectivo de mejora social y de denuncia de la violencia que origina un régimen de gobernantes indiferentes y clasistas. Tal utilización nos permite entender el carácter sincrético de la identidad nacional, pero también su carácter moral, al inscribirse en horizontes ético-políticos de vida buena para la persona y para la sociedad, pues "la imagen de orden moral no solo supone una definición de lo que es justo, sino también el contexto que da sentido a luchar por ello y a esperar su realización (aunque solo sea parcial)" (Taylor, 2006, p. 21).

Este hallazgo se contrapone a los resultados de una investigación de Lobo (2009), quien, para el caso colombiano, postula que la identidad nacional es un discurso vacío sin asidero en la realidad, pues el país no ha alcanzado los niveles de industrialización y desarrollo que garanticen las condiciones para vincular a los ciudadanos (siguiendo algunas tesis de Gellner), y, aún quienes reivindican la nación desde una perspectiva emancipatoria acuden a ella como un concepto ontológico que busca legitimar opciones ideológicas. Para este autor "los interesados tanto de la derecha como de la izquierda juegan con este fantasma, por un lado, para justificar e imponer sus planes, visiones y particularidades, y por otro lado, para intentar organizar la obediencia y, por supuesto, poder castigar la desobediencia" (Lobo, 2009, pp. 145-146).

Luego de aplicar una larga serie de encuestas a adultos en varias ciudades del país este investigador concluye que la nación es un instrumento discursivo de ciertos grupos que no tiene base en la realidad y que suple la necesidad de pertenencia grupal que las sociedades requieren a falta de otro referente. Ya que las naciones modernas se dieron en el escenario de un exitoso desarrollo capitalista que logró homogeneizar a la población y llevar una determinada cultura a todos los rincones de la sociedad, y por tanto alcanzar el estatus de nación, a las sociedades subdesarrolladas no les cabe sino la posibilidad buscarse otra etiqueta para nombrarse, según Lobo.

Al interpretar los relatos que exponen los estudiantes universitarios se puede afirmar que no es posible encontrar identificaciones naciona- 
les que excluyan dimensiones éticas, morales y políticas, más bien las abarcan, las articulan y las potencian. No se trata de elementos marginales, por el contrario, le dan sentido a la identificación nacional. Por ello, contrario a la tesis de Lobo, no es un exabrupto encontrar en los recursos argumentativos sobre la nación elementos ideológicos y políticos, al contrario: son sus huellas distintivas (Carretero \& Kriger, 2004; Carretero, Rosa \& González, 2006; Ruiz, 2011). Además, poner el norte en las naciones desarrolladas es desconocer la historicidad de toda construcción social y caer en la clásica falacia de pensar que la identidad es posible cuando las naciones preceden a los Estados, tal como supuestamente sucedió en Europa, cuando se sabe que la nación es una invención o una creación del Estado (Hobsbawm, 1991; Gellner, 1988).

Esta forma de identificación social comporta una postura política con la nación propia, que no siempre se explicita, pero que algunos jóvenes lo relievan. No hay nación sin proyecto y no hay proyecto sin una esfera política que lo apuntale. La identificación con proyectos colectivos pone de presente una esfera marcadamente política de la identificación con la nación propia, bien sea desde sentimientos de orgullo y experiencias de lealtad con la nación por venir, bien sea desde la crítica, la resistencia, la denuncia de injusticia y la proyección de una sociedad distinta. En ambos casos hay una especie de optimismo: va a ser mejor indefectiblemente, en el primer caso; va a ser mejor, pero depende de cada uno de nosotros, de nuestros microesfuerzos, en el segundo.

\section{La identificación con grupos cercanos}

La identidad nacional se construye en forma dialéctica entre la autoimagen y la imagen colectiva (Chihu, 2002). Existe un permanente diálogo entre la identidad que ofrece el grupo al que el sujeto pertenece o del grupo hegemónico en que se socializa y lo que este hace con aquella información, por ello el lugar social que ocupa cada grupo es pilar en cualquier tipo de identificación. La existencia de los grupos precede la identificación social y ellos tienen la fuerza para imponer tipos de adscripción y modos de pertenencia.

El elemento grupal es clave en el proceso de identificación nacional, pues da contenido a la diferenciación que el sujeto establece entre el nosotros y el ellos (Bolívar, 2006). Caracterizar los grupos o las personas que se considera integran el nosotros es, al tiempo, caracterizar los colectivos que hacen parte del imaginario social respecto a la nación, 
pues en el proceso de construcción de la identidad "los grupos establecen fronteras que demarcan territorios sociales entre los distintos grupos. Estas fronteras se crean poniendo de relieve las diferencias entre el mundo propio y ajeno" (Chihu, 2002, p. 8). Tras la identificación nacional existe un colectivo que preexiste a la propia existencia y que acoge el sujeto ofreciéndole una especie de alfabetización cultural y moral que le permite autoidentificarse e identificar a los demás como distintos de lo que nosotros somos. Por ello se da la identificación con aquellos con los que se comparte, con los que se cree compartir un conjunto de características similares, con los que se considera pertenecen a determinadas clases de personas (Appiah, 2007).

Para buena parte de los estudiantes universitarios participantes en este estudio, lo que nosotros somos en buena medida se resuelve en las prácticas, gustos y experiencias compartidas ligadas a lo familiar, lo doméstico, lo referencial, lo local. Veamos:

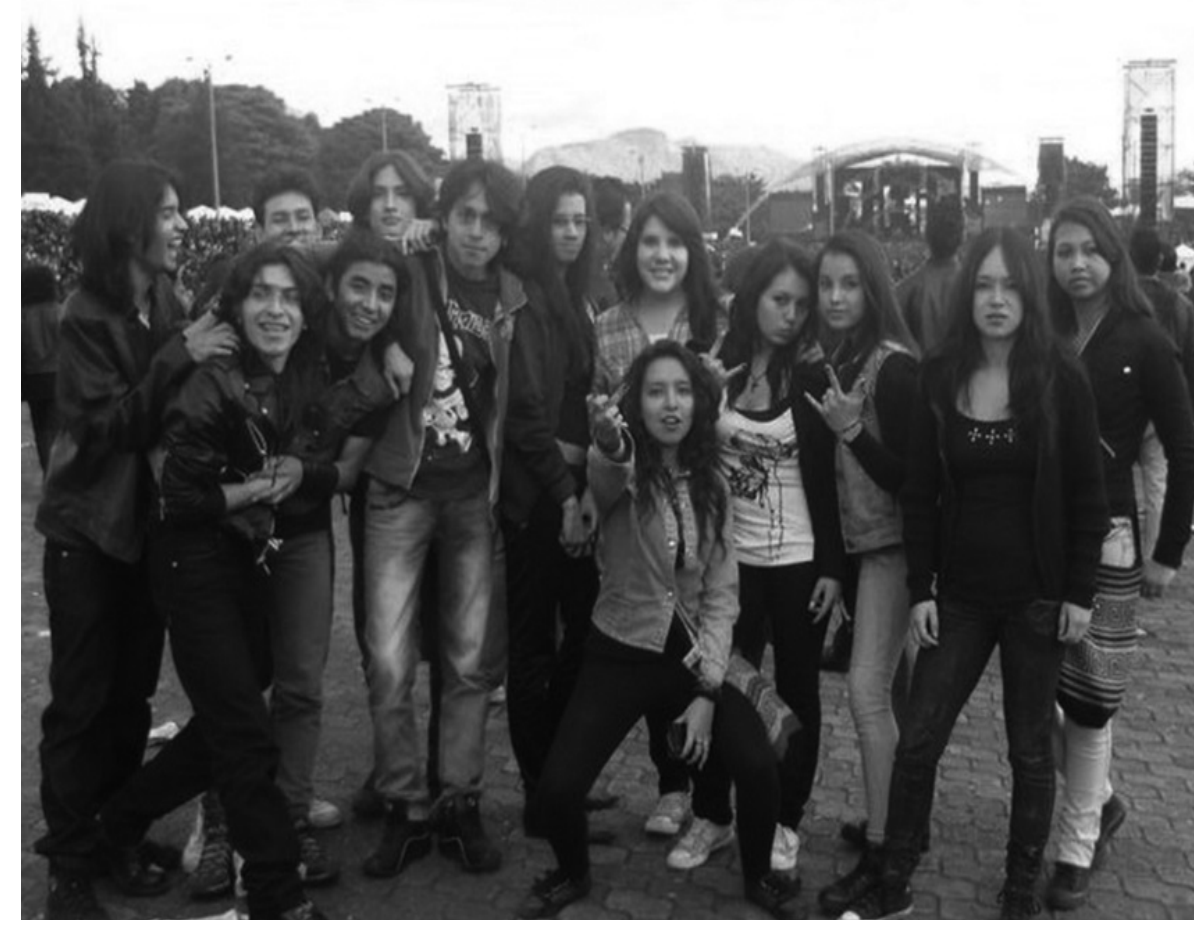

Diversidad de personalidades, convivencia y pasión por aquello que nos une como la música. Donde convergen muchas personas y al final comparten como hermanos un sentimiento y pensamiento. Aunque muchas veces se estigmaticen siempre se encuentra la manera de hacerse sentir aunque no todos estén de acuerdo (Andrés $R .-1{ }^{\text {er }}$ semestre). 
Relatos de nación y escuela. Colombia en los imaginarios de docentes en formación

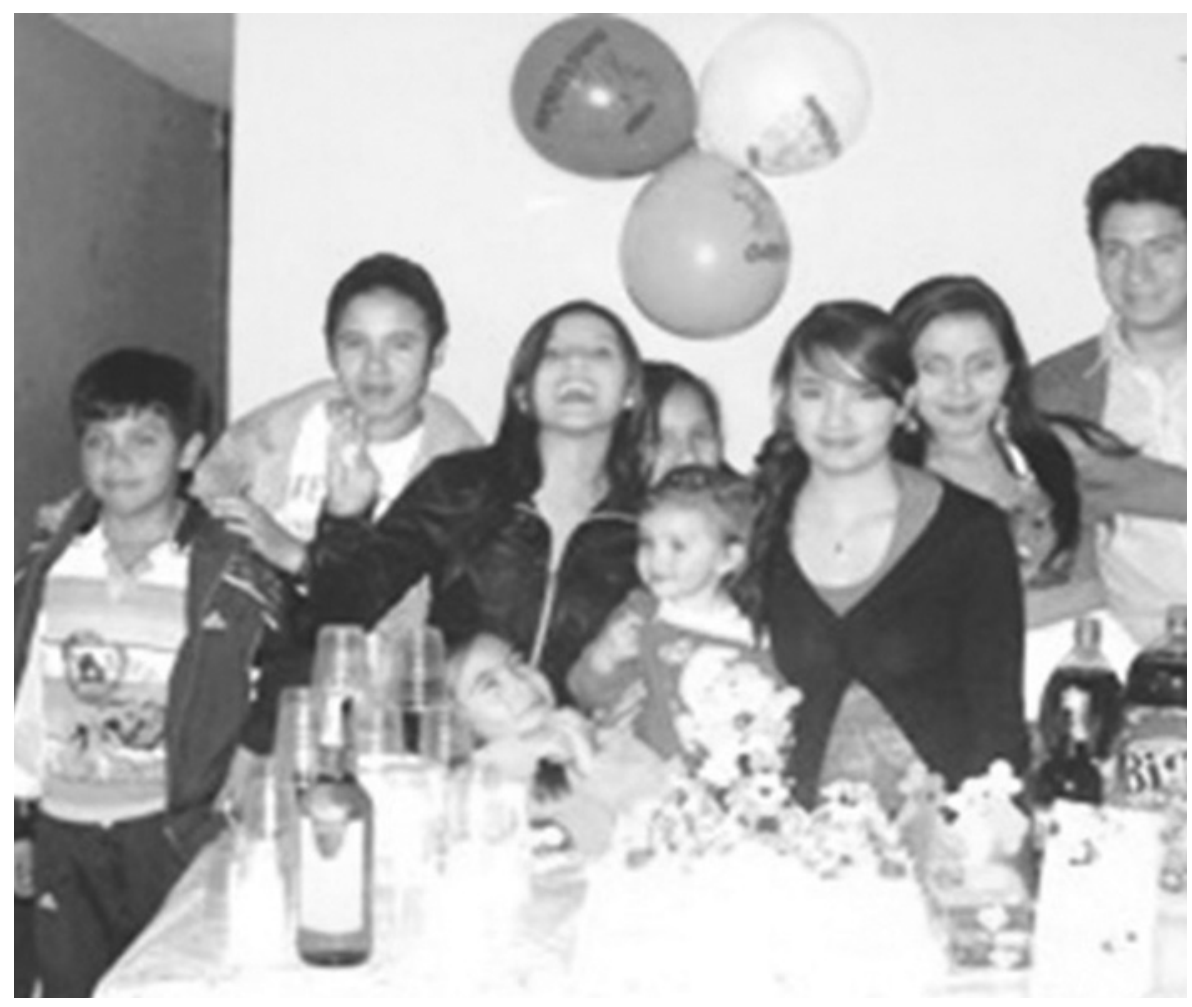

En esta fotografía aparezco con mi familia, la escogí porque creo que para los colombianos lo más importante son sus vínculos familiares, ya que por eso es que cada día salen a luchar en sus trabajos (Diana Z. - 1. ${ }^{\text {er }}$ semestre). 


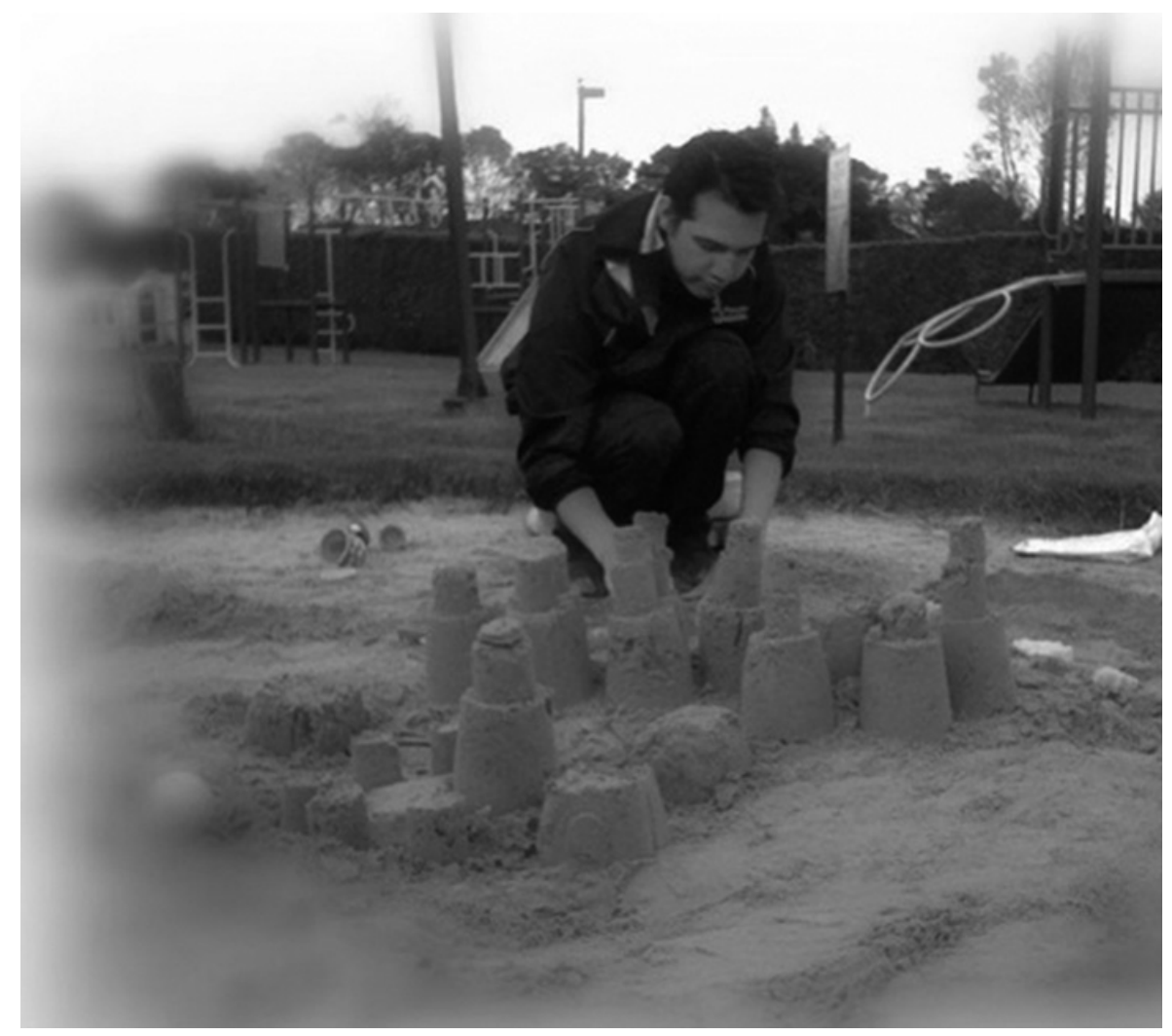

La identidad nacional es un sentimiento que he tratado de construir porque no es algo concreto que se manifieste en mis acciones cotidianas, de hecho en ocasiones cuestiono y me pregunto por qué nací en este país. A medida que van pasando los años me identifico más con un sentimiento familiar hacia este lugar. En definitiva creo que lo que me liga a este territorio es el haber nacido en la familia que nací y no el lugar o las costumbres que en él se desarrollan (Omar - 7. ${ }^{\circ}$ semestre). 
Relatos de nación y escuela. Colombia en los imaginarios de docentes en formación

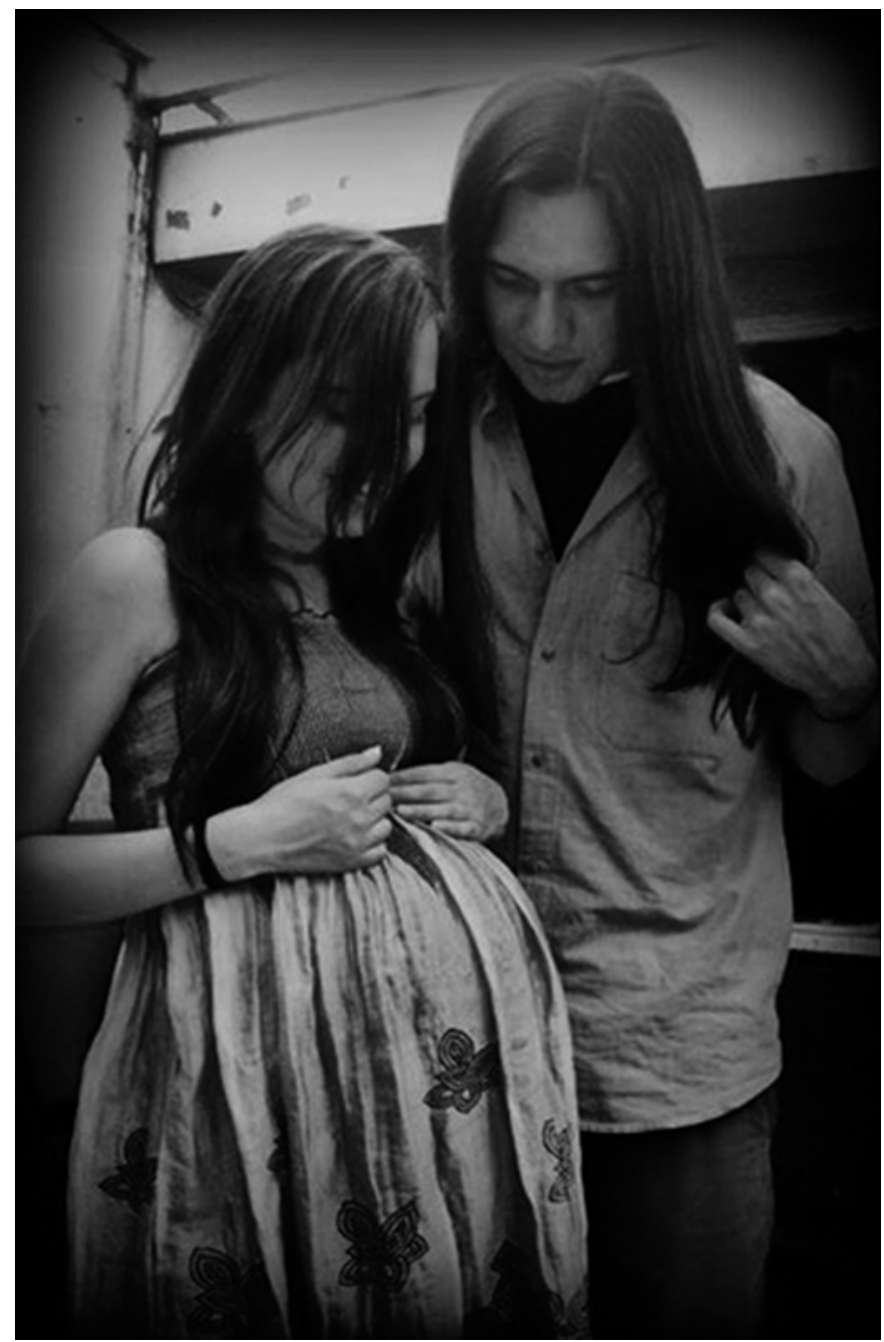

Lo que me hace sentir colombiana es el haber nacido en una tierra en la que gira toda mi vida, ver mi legado, mi familia, y que es aquí donde mi hijo nace y donde él mismo escribirá su vida (Jessica C. $-7 .^{\circ}$ semestre). 
Algunos comentarios puntuales de los estudiantes en las entrevistas:

Jogser ( $7 .^{\circ}$ semestre):

De pronto mi nación es donde pertenecen mis amigos y mi familia y donde se construye mi proyecto de vida.

Jonathan $\left(7 .^{\circ}\right.$ semestre):

Yo creo que la identidad que tengo sería de comunidad. Yo extraño mucho lo que hacíamos en el barrio, el diciembre con toda la gente del barrio tomándose unas polas ${ }^{5}$, la fiesta ahí en la calle, el fin de semana con ellos jugando fútbol en el barrio. Las dinámicas de la ciudad las extraña uno. Me siento de La Candelaria 6 , me siento identificado con el barrio. El territorio de uno no es todo Bogotá, por lo menos es un barrio, uno no conoce nada más, un barrio, dos barrios por mucho.

En buena parte de la información, como es notorio en estos relatos, fue común la alusión a grupos cercanos, familiares o locales, como expresión próxima, cercana de la filiación nacional de los estudiantes universitarios. Más allá de la explicación por la experiencia de maternidad de Jessica ("es aquí donde mi hijo nace") o de la añoranza de Jonathan ("extraño lo que hacíamos en el barrio), estos fragmentos refuerzan el vínculo con grupos cercanos al ámbito de acción de estos jóvenes. De manera que si la identidad es una situación relacional entre actores sociales (Giménez, 2002), estos y otros relatos nos hablan de experiencias de sentido hacia lo nacional que pasan por sentimientos de vínculo hacia lo inmediato y hacia una filiación más directa, doméstica.

De cierta forma esta tendencia va en contravía de ciertos presupuestos teóricos sobre la identidad nacional. Por ejemplo, para Smith (1997) las referencias a la identificación nacional tienen un componente de filiación familiar muy importante, en tanto da la materia prima para experimentar sentimientos de hermandad y camaradería; de alguna manera una nación es una inmensa familia de hermanos y hermanas que se no se conocen aún, pero para que sea nación, según el autor, precisamente se necesita que este vínculo se extienda más allá de los lazos de consanguinidad. En los estudiantes participantes dicha relación, si bien no se agota en esta esfera de parentesco, es una referencia fuerte que alcanza para marcar una diferenciación entre los cercano, lo familiar y lo desconocido, lo ajeno. En la misma línea, Anderson (1993) enfatiza

\footnotetext{
$5 \quad$ Cervezas.

6 Barrio tradicional de Bogotá.
} 
en la idea de nación como comunidad imaginada porque se desarrolla la capacidad de inculcar en los connacionales sentimientos de empatía con personas que viven más allá de los límites domésticos de contacto diario o convivencia cotidiana. En los tiempos presentes, tal y como se confirma en este estudio, para un grupo importante de estudiantes tal sentimiento se reduce considerablemente a círculos estrechos de afinidad social y política en que la nación es el contexto más amplio que contiene lo cercano.

El cara a cara, que supuestamente debe ser rebasado para alcanzar la condición de unión nacional, es vivido por estos estudiantes en su condición básica de proximidad y cercanía, de entorno y afectos, tal como se puede inferir de sus narrativas. El grupo de amigos, la reunión familiar, el hijo o la hija que se espera, irrumpen como referentes identitarios para responder a la pregunta por la identidad nacional, estos elementos son reemplazos de la nación en una suerte de sinécdoque en el que una parte busca ser usada para dar cuenta del todo.

Este hallazgo está relacionado con la fuerza de las adscripciones al territorio mencionada en otro apartado y, en consecuencia, con la manera como se materializa un relato nacional que incluya a los colombianos en una sola comunidad. En estos estudiantes universitarios, salvo pocas excepciones, la pertenencia alcanza la ciudad o el pueblo de nacimiento, y son las personas cercanas las que se convierten en el grupo que carga de sentido la idea de la filiación y prácticamente la circunscribe allí, dejando por fuera apelaciones más amplias, vinculaciones imaginarias más comprensivas.

Si la identidad tiene que ver con las condiciones de interdependencia sociales (Elias, 1987) y cambia de acuerdo a los procesos de integración social, la identificación con el grupo próximo puede darse por dos fenómenos: como parte de la creciente tendencia al encapsulamiento en la esfera íntima que el capitalismo contemporáneo insufla (Sennett, 1978) y como respuesta al déficit de experiencias que vinculen a los ciudadanos en un proyecto colectivo, es decir, a la debilidad de un nosotros nacional. En efecto, según Richard Sennett vivimos actualmente el declive de lo público, que se concreta en cambios en las relaciones sociales que consisten en el gradual repliegue hacia la vida íntima por parte de los sujetos, vida valorada como superior en un intento de solucionar el problema público, negando el impacto de lo público en sus vidas y optando por resolverlo en los microespacios sociales. 
Para María Teresa Uribe (2001), en sociedades tan fragmentadas y polarizadas como la colombiana los ámbitos de las identidades colectivas se restringen a sus formas más simples como la familia, el vecindario, las asociaciones primarias y las relaciones cara a cara debido a la débil y precaria presencia del Estado en las regiones. Ante el vacío de un nosotros común vinculante en el ámbito nacional, muchas personas solo experimentan pequeñas adscripciones circunscritas a los lugares de interacción cotidiana. Por ello se entiende que la familia o el grupo ocupen el lugar de la referencia nacional, ni siquiera la suplantan o la eliminan, simplemente ocupan ese lugar referencial. La presencia de un nosotros nacional supone la permanencia de un fuerte capital social relacionado con las políticas públicas de los Estados (Lechner, 2002), lo que permite establecer relaciones de confianza y cooperación social como condición de posibilidad para que las personas sientan que comparten algo en común con sus connacionales. La debilidad del vínculo social que impulsa anclajes solo con los conocidos se conecta con un vacío de Estado, con una sensación de intemperie social que corroe el sentimiento de vínculo a la nación propia.

Si en el primer apartado de las vinculaciones reseñado atrás la nación pasaba por el territorio y la cultura en tanto enclaves de identificación nacional, para la mayoría de los estudiantes participantes en este trabajo y para otros tal identificación revelaba su cariz político, al asociarse con proyectos de transformación social y dignificación humana. Para el último grupo, por diferentes razones, el "lugar" de la nación, sus apelaciones y referencias lo ocupan los grupos y personas cercanas afectiva y físicamente, en quienes son interpelados por el contenido de la identidad nacional. 



\section{ESTEREOTIPOS SOBRE COLOMBIA}

En el apartado "vínculos y pertenencias" la atención del análisis se centró en las formas de adscripción y pertenencia que invocaron los estudiantes universitarios al momento de ser conminados a hablar sobre su identificación con la nación propia. En el presente apartado se enfatiza en los recursos narrativos que los jóvenes utilizan para referirse a lo que consideran significa la nación en sí misma y responder a la pregunta: ¿qué elementos identitarios se destacan de la simbología y de los aspectos representativos y emblemáticos de Colombia?

La diferencia entre uno y otro asunto es sutil y con frecuencia su distinción en los relatos de estos jóvenes se hace difícil, dado que los discursos sobre la identidad nacional se configuran, en buena medida, con y desde la imagen -simbología- que se tiene de la nación propia. De cualquier forma, es importante destacar que analíticamente mientras la primera - adscripción personal y pertenencia a la nación-interpela lo íntimo y lo personal (por ello la importancia de los relatos visuales en los que los estudiantes se representan a sí mismos como colombianos), la segunda —relieve de aspectos simbólicos y representativos de la nación- explora posicionamientos frente a algo aparentemente exterior, es decir, indaga la forma como estos jóvenes reaccionan a representaciones colectivas y frente a referencias genéricas o estereotipadas de la nación. Incluso, en ocasiones en las que los estudiantes intervienen las imágenes de sí mismos en las fotografías, como se verá, el énfasis está puesto en la nación, en los imaginarios de Colombia como ente histórico-cultural. Sobre este último acento, que da una especie de continuidad a la frase "Colombia es...", trata la presente sección que hemos denominado por las razones anteriores expuestas: estereotipos de nación. ${ }^{1}$

La pregunta por la imagen de Colombia que cada uno porta, hecha a los estudiantes, redundó en tres tópicos que contaron con diferentes niveles de aceptación y que a continuación se exponen: en primer lugar: la cultura que nos une, desde la cual se destaca la importancia de la diversidad, el folclor y los paisajes de la geografía colombiana; en segundo lugar, bajo el título Colombia es pasión, conjunta los relatos que coinciden con la identifición de lo colombiano unido a la alegría, la emotividad y la tenacidad en las acciones cotidianas de las personas;

1 El término estereotipo se usa aquí en un sentido lato, sin connotaciones valorativas, como "imagen o idea aceptada comúnmente por un grupo o sociedad con carácter inmutable" (Diccionario de la lengua española, 2001). 
y finalmente: en las carencias e infamias que nos marcan se agrupan las respuestas sobre los diversos y profundos problemas históricos que, según los jóvenes, han sido el elemento distintivo de la colombianidad y su condición de existencia.

\section{La cultura que nos une}

La rememoración de costumbres, reales o inventadas, ha sido uno de los acervos más estudiados para entender los mecanismos de funcionamiento y perpetuación de la nación y de la creación de sentimientos de identificación con ella. Un pasado glorioso, una tradición común y unas prácticas socialmente compartidas, rutinizadas y ritualizadas en la escuela y fuera de ella, son algunos de los aspectos que hacen parte de las políticas de la memoria impulsadas por los Estados (Hobsbawm \& Ranger, 1983). En el presente estudio fue visible este recurso que acude a elementos del pasado para definir la esencia de la nación colombiana, en este caso ya no a partir de gestas heroicas o de hechos históricos emblemáticos, sino que contó fundamentalmente con el realce de la diversidad, de las prácticas culturales particulares y con una fuerte valoración del paisaje y la naturaleza como caracteres distintivos. Veamos algunos relatos significativos al respecto: 


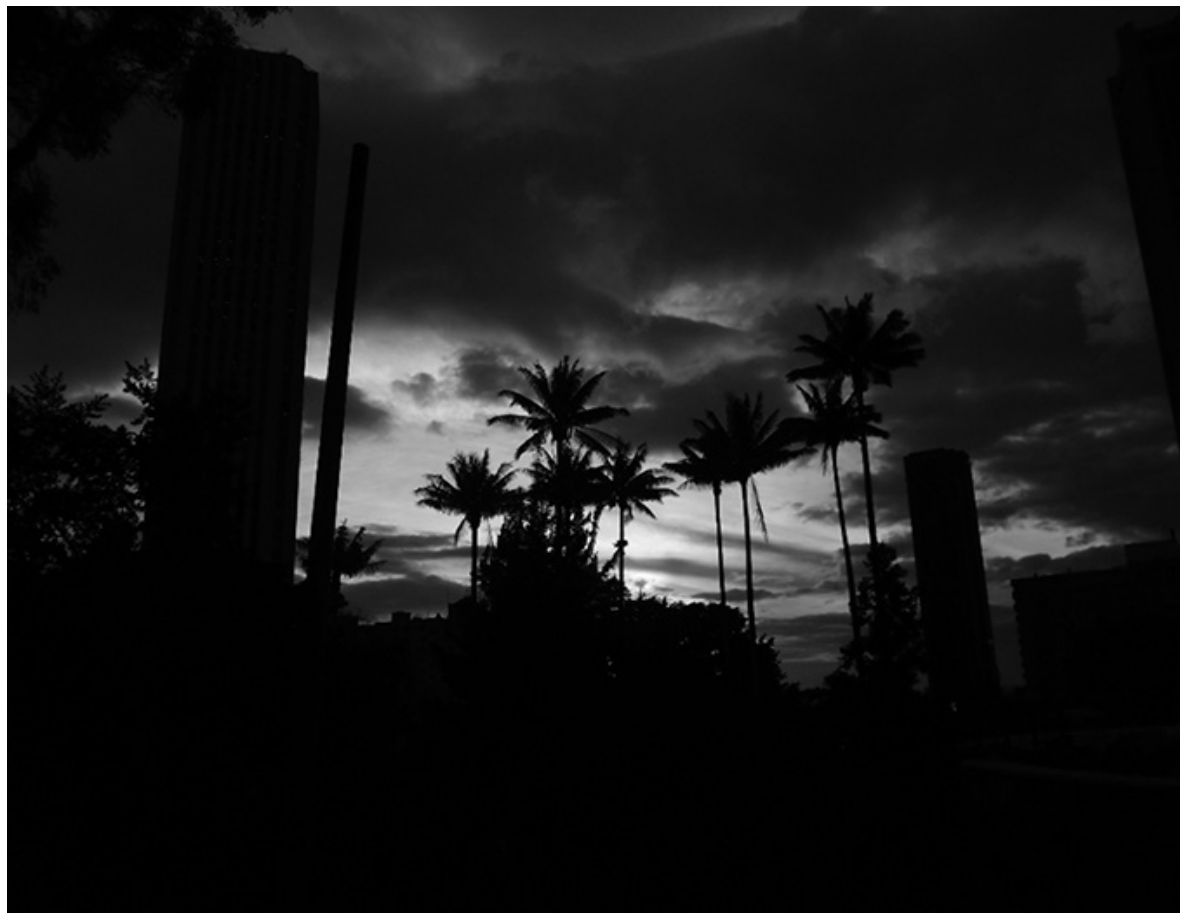

En nuestro país lo que más abundan son los recursos, tanto naturales como culturales [...] la cultura que para mí se ve reflejada en esta foto: centro de Bogotá, lugar de la mayor cantidad de choques culturales en el país. En la carrera séptima se divisa gran cantidad de biodiversidad cultural que se puede encontrar en Colombia, y esta me parece su característica significativa (Daniela R. -1 er $^{\text {er }}$ semestre). 
Relatos de nación y escuela. Colombia en los imaginarios de docentes en formación

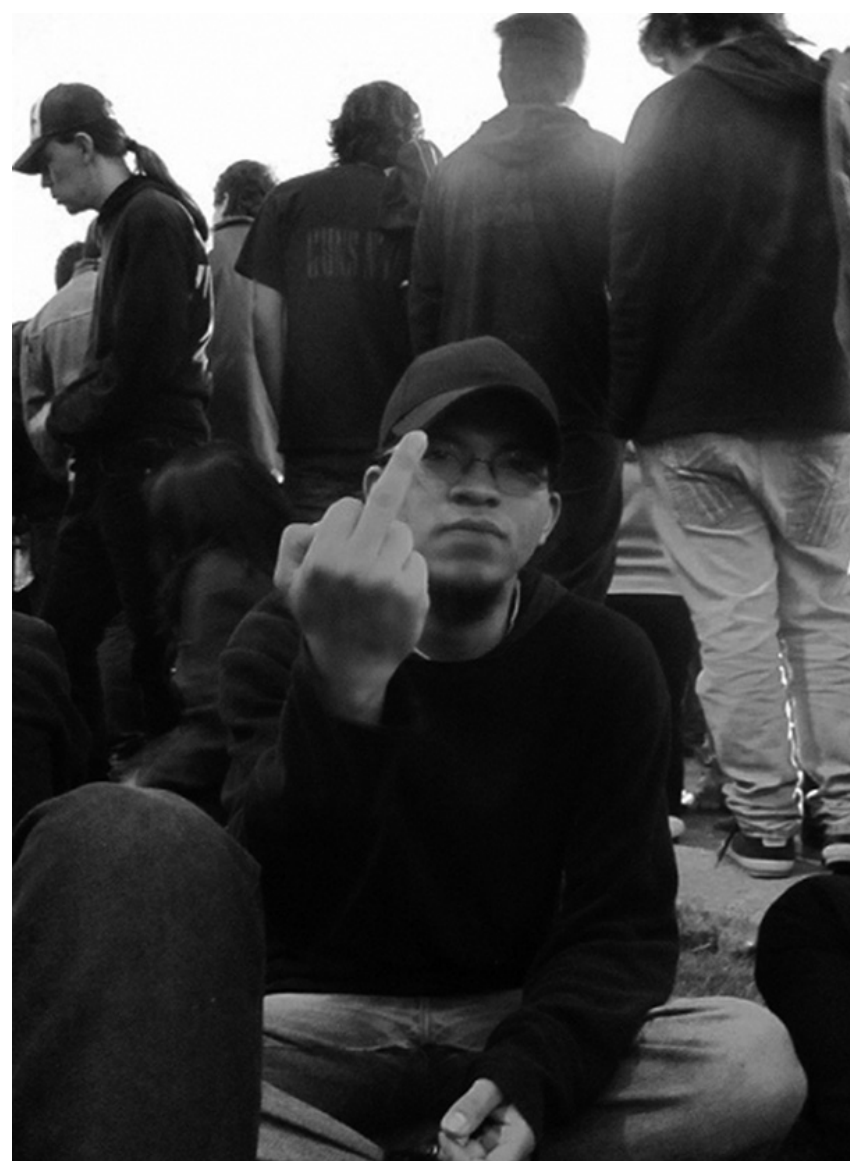

La foto que presento fue tomada en "Rock al Parque 2012" y la elegí ya que es un evento en donde se encuentra la cultura y la diversidad. Pienso que como colombiano son las cosas que más me identifican... Esta foto representa, en mi concepto, a Colombia, porque es un evento al que concurren las personas a disfrutar de la cultura, la diversidad y el calor humano (Sebastián G. $-1 .^{\text {er }}$ semestre). 


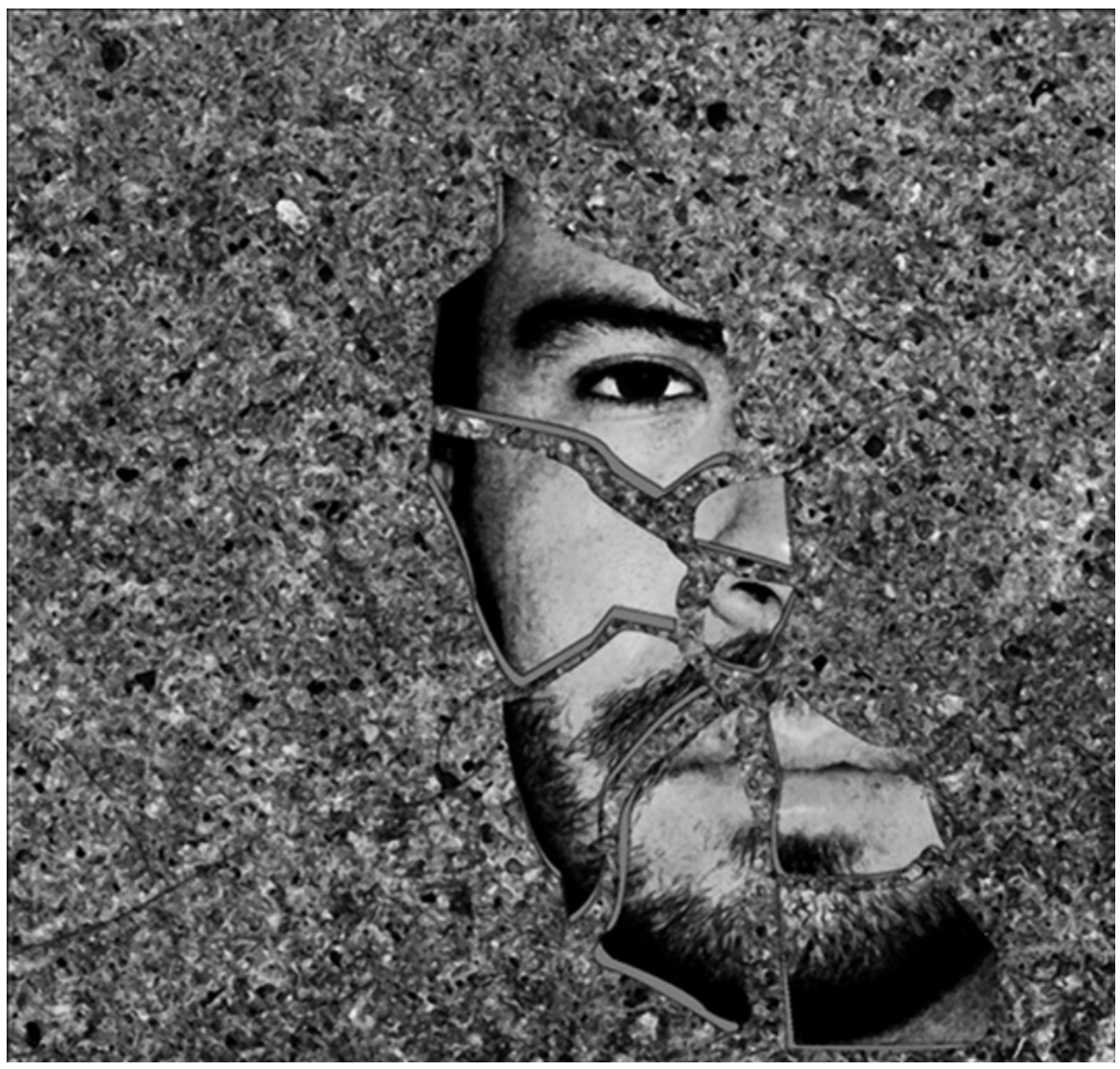

Me parece que procedemos de un mestizaje cultural, racial, étnico, que primeramente significa una pluralidad, pero que nunca se ha pretendido poner en diálogo, al contrario, toda esa amalgama de etnias y culturas [...] se ven permeadas por la mediatización y el mercado cultural que pretende folclorizar y hacer objeto de consumo todo lo que parece exótico, alejando la posibilidad de democratizar y conocer la diversidad en Colombia. El problema no es la diferencia, sino el obstáculo en crear puentes de diálogo entre culturas (Diego B. - 7. ${ }^{\circ}$ semestre). 


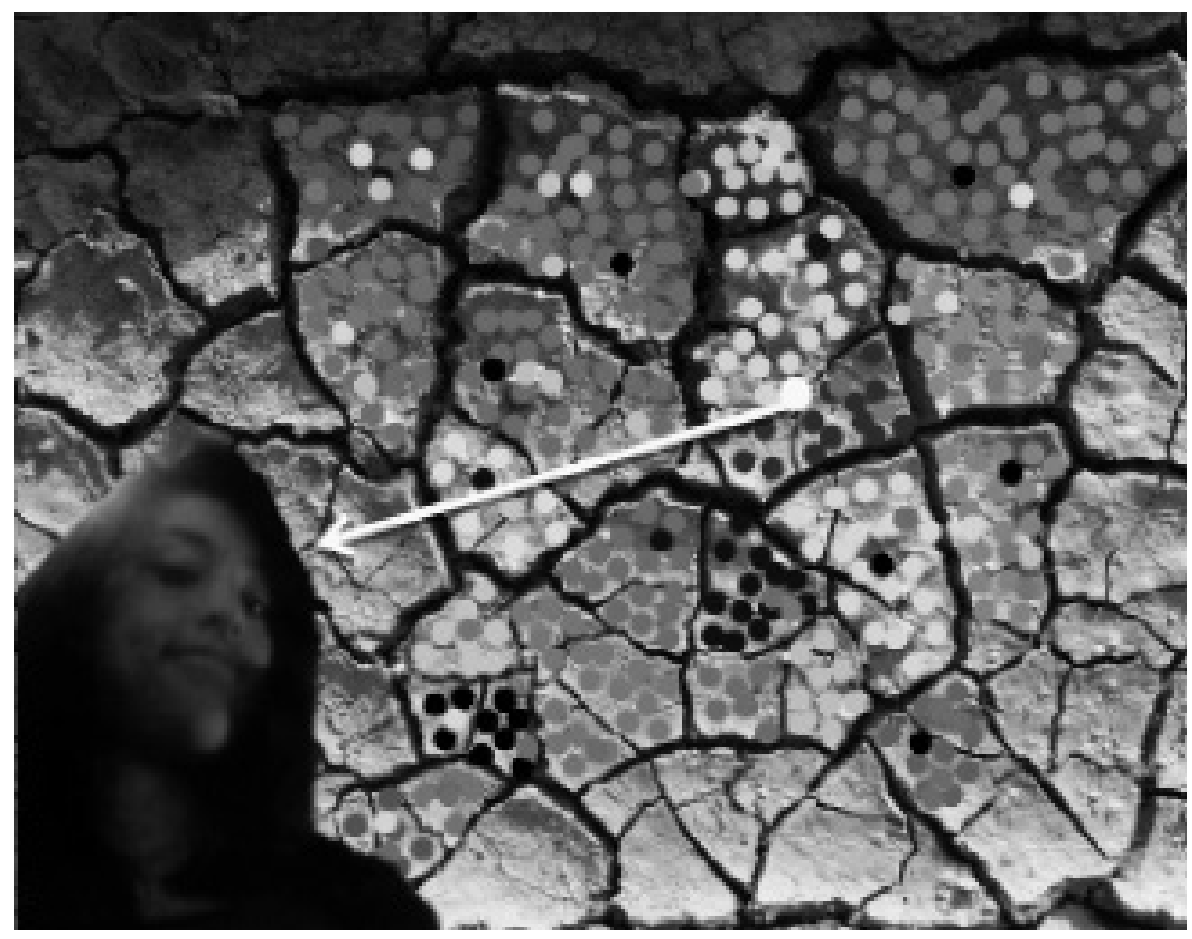

Colombia ha significado desde sus inicios un país pluriétnico, multicultural, gracias a la diversidad de lenguas, paisajes y gentes, en sus maneras de actuar, en su formación de carácter, acciones y expresiones en el mundo social [...] En esta foto podemos encontrar una representación del mapa de Colombia, en donde se vislumbra una serie de puntos de muchos colores que serían las personas que viven en ese lugar, con sus múltiples personalidades, caracteres y acciones. Eso significa cada color, en donde en cada lugar hay unas expresiones comunes, pero también existe la diferencia de personas que provienen de otro lugares, con tradiciones ancestrales y cósmicas, posicionando así su lugar, el del nacimiento de la madre tierra. Hay tres planos, en el primero me encuentro yo con un color y una forma propia de ser y actuar, según mi familia, mis grupos de pares y el territorio donde me encuentro. En segundo plano se encontraría el bosquejo abstracto con sus imperfecciones, la representación simbólica de Colombia y, finalmente, el tercer plano sería la tierra agrietada por efectos de la naturaleza, pero, a su vez, por acciones del hombre y su habitar en el mundo (Jenny C. $-7 .^{\circ}$ semestre). 
Estos relatos visuales, acompañados de breves párrafos explicativos, que tienen en común términos como diversidad, naturaleza y cultura, son complementados y reforzados con algunas respuestas de otros estudiantes a las entrevistas:

Diana Z. (1. ${ }^{\text {er }}$ semestre):

Lo más representativo es como la gente, la diversidad... [Colombia] tiene muchas etnias, mucha flora, mucha fauna.

Juan G. (1. ${ }^{\text {er }}$ semestre):

Para mí la magia es cotidiana, que llueva para mí es mágico, el poder mojarme, el poder sentir el sol. Por ejemplo, que estemos aquí en los Andes, que uno pueda ver las cosas bonitas de la vida y que uno pueda decir que uno vive en un país hermoso, que vive en un país muy natural, por decirlo así, muy diverso. Tanta gente. Si yo viajo media hora, de aquí a Silvania, ya es otra gente. Si yo viajo ocho horas, ya parece otro país. Es tan diverso este país, se hace tan diverso, que es muy bello. Eso es lo bello.

Karen (1. ${ }^{\text {er }}$ semestre):

Lo mucho que le apasiona a uno esta tierra, los paisajes y todo eso lo hacen sentir a uno bien, frente a otros lugares del planeta. Eso me parece bonito de Colombia, como la gente también, la amabilidad de la gente. En un sentido, estoy orgullosa de Colombia en la parte de riqueza, en cuanto a paisajes, a la gente.

Jogser $\left(7 .^{\circ}\right.$ semestre):

Pues se me viene primero más que el amarillo azul y rojo, se me viene el verde, porque pienso que en un principio es un país verde, un país que [...] convoca una diversidad biológica y una diversidad que de pronto hace que sea un país muy rico y muy diverso en cuanto su territorio, por ello la gente, sobre todo, a su nivel cultural y social. Entonces, se me viene primeramente el verde como país.

Lizeth $\left(7 .^{\circ}\right.$ semestre):

¿Qué es lo más representativo de Colombia? Para mí la culturalidad, o sea, Colombia son muchos mundos, muchos lenguajes, muchas formas de existir, en un solo mapa, que es muy difícil tratar de estereotipar, aunque se haya intentado por medio de la cultura del café. Colombia tiene mucho más, tiene otras formas de existir, ya sea en el campo o en la ciudad, que coexisten. Para mí, Colombia 
es como [...] más que el amarillo, azul y rojo, para mí es el whipa$\mathrm{la}^{2}$, son todos los colores o muchos colores juntos en una bandera que para mí es como el ideal de lo que representa Colombia. La coexistencia de las diferencias culturales y todo lo que traen.

Para los relatos de estos estudiantes universitarios la palabra 'Colombia' evoca diversidad y riqueza cultural, variedad de razas y pluralidad de expresiones sociales. Esta acentuada diferencia en todos los ámbitos es vista como un elemento positivo ("la diversidad es bella", dice Juan) y como un rasgo distintivo de la nación "Colombia son muchos mundos", afirma Lizeth). La pluralidad cultural y la variedad natural se solapan en un reconocimiento de lo que Colombia es, por ello las políticas públicas o los escenarios que potencien esta dimensión son valorados, y lo contrario, las acciones y los procedimientos que menoscaben o atenten contra esta diversidad son señalados por estos jóvenes como injustos, denigrantes y objeto de lucha (Diego critica las estrategias del mercado que folclorizan y exotizan, mientras que Lizeth cuestiona el estereotipo del café).

En este ensalzamiento de la diversidad los estereotipos ligados a los colores de la bandera o los productos típicos son rechazados, por cuanto no reflejan la riqueza del país, por lo que Jogser, Lizeth y Jenny en su fotografía señalan que Colombia es más que los colores de la bandera y más bien sugieren diálogos culturales, puentes y mecanismos que conecten de múltiples formas las variadas expresiones que conforman la nación. Esto lo precisa, especialmente, la afirmación de Diego respecto a que lo importante es tender puentes de diálogo.

Decir que la cultura nos une implica destacar que lo común es la diferencia, las decenas de puntos de colores que se reúnen en un mismo territorio, como lo indica Jenny en su relato visual. Lo que nos une es la explosión y coexistencia de lo particular. Entiéndase aquí por cultura el sentido más amplio del término, es decir, las prácticas, productos y consumos ligados a la vida de comunidades particulares, especialmente populares, que fungen como mecanismo de diferenciación frente a otros grupos (García, 2002).

Esta acepción de cultura, esbozada por los estudiantes participantes del presente estudio, dependiente de las condiciones materiales, naturales y étnicas de la nación, no es reconocida en su conflictividad e historicidad, más bien se alude a ella como carácter esencial que portan los grupos. De manera que el relato nacional que se construye, si

2 La estudiante alude al nombre con el que algunas etnias de la región se refieren a la bandera de múltiples colores, símbolo de la cultura indígena. 
bien prescinde, en primer instancia, de una épica heroica, acude a un mito fundacional (Urrego, 1998), en este caso el de la diversidad y de la diferencia, y sirve de núcleo discursivo generador sobre el cual gravitan los demás acontecimientos ("el ideal"), con el cual se establecen vínculos y valoraciones ("lo bello"), hacia donde se camina y de donde se quiere partir ("Colombia es whipala") y, por supuesto, el lugar de los afectos y de las adscripciones ("estoy orgullosa", "el calor humano").

En esta afinidad con las expresiones culturales de la nación propia sucede una transición, descrita por García (1995), según la cual la identidad deja de ser una membresía intemporal ligada exclusivamente a la historia, aproximándose mucho más a la esfera de las artes, la literatura o el folclor, a su vez permeada por "los repertorios textuales e iconográficos provistos por los medios electrónicos de comunicación y la globalización de la vida urbana" (p. 95). Es decir, buena parte de las expresiones culturales que son valoradas por estos estudiantes, de clase media urbana y, quizá, adquirida especialmente a través de los medios de comunicación visual, deviene en el escenario en el que se hace posible la valoración de la diversidad cultural como el lugar de lo nuestro. No obstante, la mayoría de estudiantes entrevistados reconocen muy pocas experiencias directas de exploración de paisajes nacionales gracias a esporádicos viajes familiares o escasísimas salidas de campo universitarias.

La reificación de lo diverso ha sido una estrategia discursiva impulsada por el poder desde el marketing de los medios y por el turismo, y sirve como 'tropo' que da contenido a lo supuestamente propio, sustituyendo de alguna manera el déficit de vínculo que las políticas públicas o la institucionalidad resuelven insatisfactoriamente. Al igual que en anteriores apartados, la distancia respecto al Estado se nivela con compensaciones adscriptivas a la nación, en este caso, supuestamente rica en variedad y multiculturalismo. El resultado: una nación a la espera de ser descubierta y explorada (Vive Colombia, viajapor ella) ${ }^{3}$, con infinidad de grupos, bailes y lugares, cuya rica cultura y miríada de expresiones urge de ser conservada, reconocida y, sobre todo, visibilizada ${ }^{4}$.

3 Fue un programa ampliamente difundido de promoción turística durante el gobierno de Álvaro Uribe en su primer mandato, en el ámbito de la política de seguridad democrática, con el fin de incentivar los viajes por todas las zonas del país. El programa organizaba caravanas hacia destinos de interés cultural y recreativo.

4 El Ministerio de Cultura de Colombia cuenta con un ente denominado Grupo de Patrimonio Cultural Inmaterial con importantes espacios en las cadenas televisivas públicas y privadas, cuyo propósito es generar sentimientos de identidad y establecer vínculos con la memoria colectiva. "Es transmitido y recreado a lo largo del tiempo en función de su entorno, su interacción con la naturaleza y su historia y contribuye a promover el respeto por la diversidad cultural y la creatividad 
Esta cultura que nos une, en tanto tendencia que comprende la colombianidad como confluencia de diversidad natural y riqueza cultural, está en sintonía con la manera como se suele celebrar la nacionalidad en los actos y fiestas protocolarios escolares y cívicos: música, danza, culinaria. En ellos se admite que la nación se corresponde con aquellas expresiones propias de ámbitos específicos, especialmente de baile y de música, tanto tradicionales como modernos, que representan lo nuestro. Este estereotipo también tiene su correlato en íconos contemporáneos de la música como Juanes o Shakira, en artistas como Botero o en escritores como Gabriel García Márquez, personajes que fueron esporádicamente mencionados a lo largo del estudio como emblemáticos de lo que significa o representa a Colombia. En un sociedad globalizada estos nombres internacionalizan lo colombiano al dar a conocer producciones culturales propias remasterizadas para el mundo. Colombianos famosos que no viven en Colombia nos representan en tanto nutren, inspiran o tematizan sus producciones de la realidad colombiana.

Al decir de Smith (1997), además del territorio y la igualdad políticolegal de sus integrantes, una de las condiciones de existencia de la identidad nacional tiene que ver con cierta dosis de cultura colectiva y una ideología cívica. A este nivel importan los recuerdos históricos, los mitos, las tradiciones y los símbolos colectivos. Tales recuerdos son dotados de contenido en la diversidad cultural y natural en el imaginario de muchos colombianos y que ponen en evidencia algunos jóvenes estudiantes participantes de la presente muestra.

Las variopintas expresiones que supuestamente nos constituyen como nación son funcionales a la armonía del sistema, ya que nadie se queda afuera, todos tenemos un lugar en el espectro nacional y cada quien, individual o grupalmente considerado, tiene su espacio, su color, su nicho. Pero no aparece la idea del nosotros como actor colectivo (Lechner, 2002), no hay proyecto conjunto, aspecto básico para la cuestión política, solo un supermercado disperso y dispuesto de consumos y producciones culturales que sobreviven a costa de reclamar una vitrina para no ser anónimos.

Siguiendo a Nobert Lechner, se puede colegir que las consecuencias políticas de esta imagen son caras y pueden redundar en la incapaci-

humana". Fuente: http://www.mincultura.gov. co/?idcategoria=1285 (21-08-2013). Por otro lado, ciudades como Bogotá desde 1995 organizan anualmente festivales públicos de música que satisfacen la demandas de los más variados gustos: Rock al Parque, Colombia al Parque (con dos subcategorías: zona andina o llanera y zona costas o región insular), Salsa al Parque, Jazz al Parque y Hip Hop al Parque, entre otros. 
dad de encontrar un sentimiento colectivo que dé fuerzas para perfilar un orden deseado y, por tanto, para tramitar los mecanismos políticos que hagan que este se lleve a cabo. Aquella mirada sobre la cultura, que destaca las diferencias para exhibirlas pasivamente junto con otras, es vaciada de su carga política al considerar a las personas y a las colectividades como entes acabados y al suavizar al extremo las fuerzas que rozan por describir y, por tanto, prescribir (Bourdieu, 1981) lo que estas son y deberían ser. Ello también habla de la existencia de un relato estatal sostenido y mediático que privilegia la naturaleza y las expresiones culturales como improntas de lo nacional, en detrimento de otras ofertas institucionales para generar causas comunes y sentimientos de filiación en buena parte de los colombianos.

\section{Colombia es pasión}

La atribución de características positivas al grupo social al cual se pertenece es un aspecto nodal en la definición de la identidad social. Parte de los ejercicios de etiquetamiento impone el manejo de ideas y valoraciones que no solo sirven para comprender la realidad, sino que pasan a tener efectos psicológicos y sociales al "configura[r] las maneras en que las personas se conciben a sí mismas y conciben sus proyectos" (Appiah, 2007, p. 117). Este proceso de identificación opera Ilenando de particularidades - que lo hacen diferente a otros grupos-al colectivo al que el sujeto se adscribe. Según Appiah, tales criterios deben circular en el espacio público, ser reconocidos por los miembros de la sociedad y tener cierto grado de consenso social respecto a cómo identificar a aquellos a quienes debería aplicar esos términos. Sobre una modalidad de estos etiquetamientos trata el presente acápite.

En sintonía con el apartado anterior, buena parte de los relatos de los jóvenes destacaron un elemento positivo de la realidad nacional: ya no sus paisajes o sus expresiones culturales, sino las características de las personas que habitan este territorio, tales como su carácter, su genio y su idiosincrasia. Veamos: 


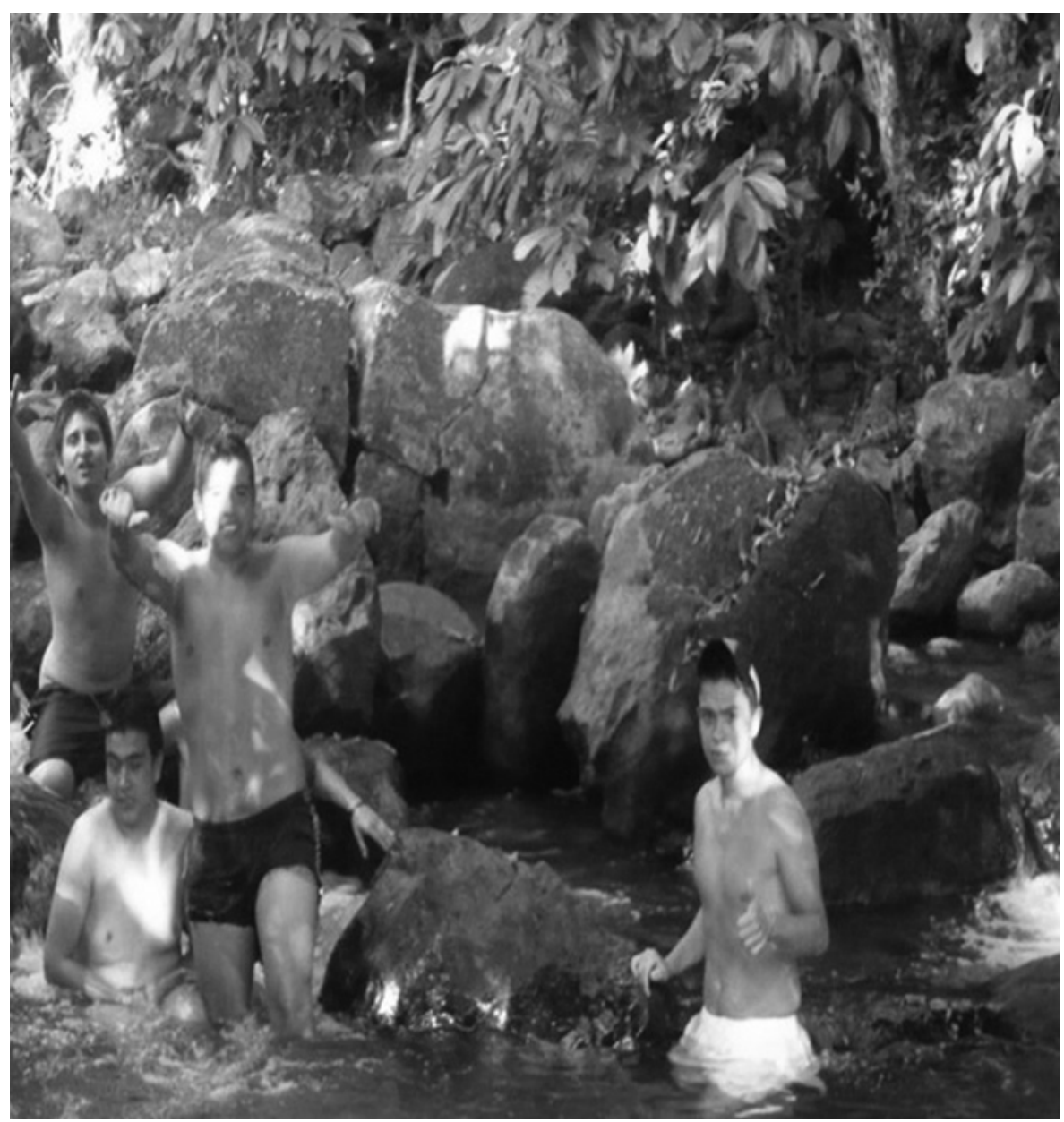

Coloco esto porque los paseos de río son muy característicos de nuestra cultura. Esa foto se tomó en el parque de San Gil, que está cruzado por dos ríos y antes fue un asentamiento de los motilones ${ }^{5}$. La unión y la amistad caracteriza muy bien la manera en que los y las colombianas conviven y se expresan. La felicidad es evidente en Colombia, se puede decir que Colombia es el país más feliz del mundo, pese a la violencia. Esta foto es evidencia de que Colombia y el mundo pueden cambiar con unas sonrisas (Jorge $-1{ }^{\text {er }}$ semestre).

5. Comunidad indígena precolombina. 


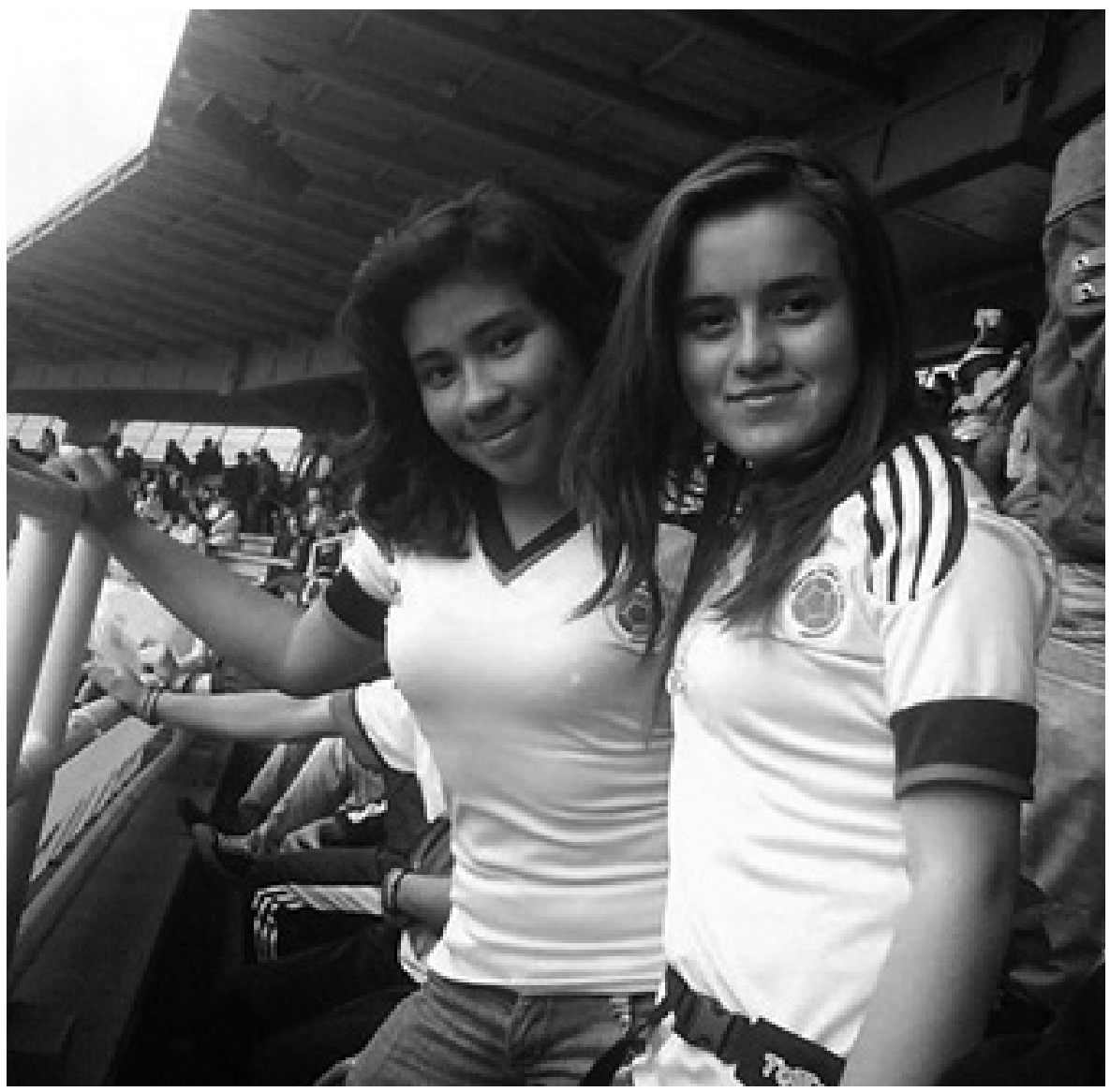

En la fotografía me encuentro en el estadio junto con una amiga en un partido de la Selección Colombia; más que ocupar un asiento, es ser una voz de aliento y de apoyo a quienes nos están representando en un campo de juego, un momento lleno de emociones. Porque además de pasión por el fútbol, me llena de alegría saber que millones de personas se reúnen en un solo lugar para apoyar a su equipo y para vibrar con el solo hecho de ser colombianos (Natalia - 1. ${ }^{\text {er }}$ semestre). 


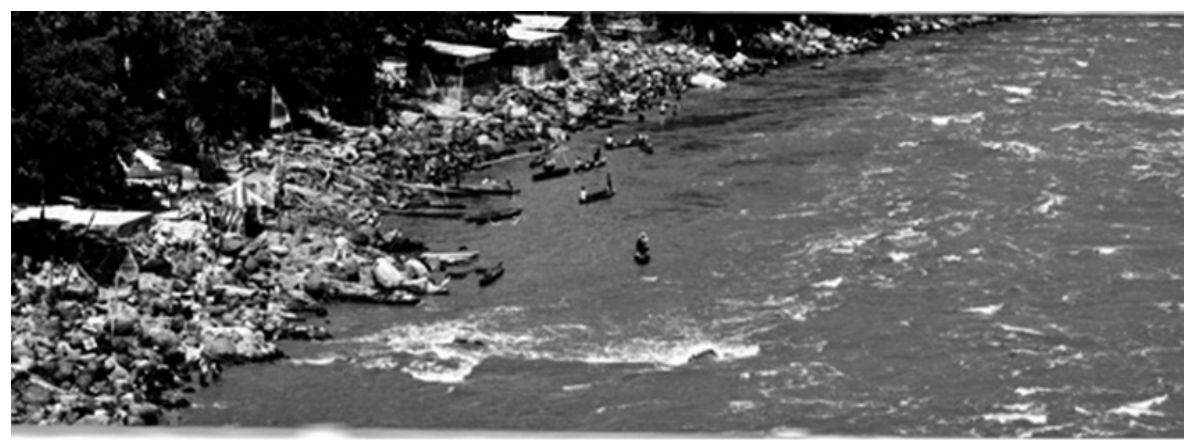

Pienso que representar lo que es Colombia solo se puede lograr parcialmente, ya que es difícil la caracterización de una identidad unificada en un país tan plural, diverso y mestizo. En la fotografía se evidencia un poco la persistencia de la figura del trabajador informal, dependiendo del rebusque y a merced de los embates de la naturaleza. ¡Qué mejor figura que el pescador como personaje que depende de la contingencia de la naturaleza! Este colectivo de pescadores representa un poco la vida austera y humilde de lo que es la realidad generalizada en Colombia (Diego B. $-7{ }^{\circ}$ semestre). 


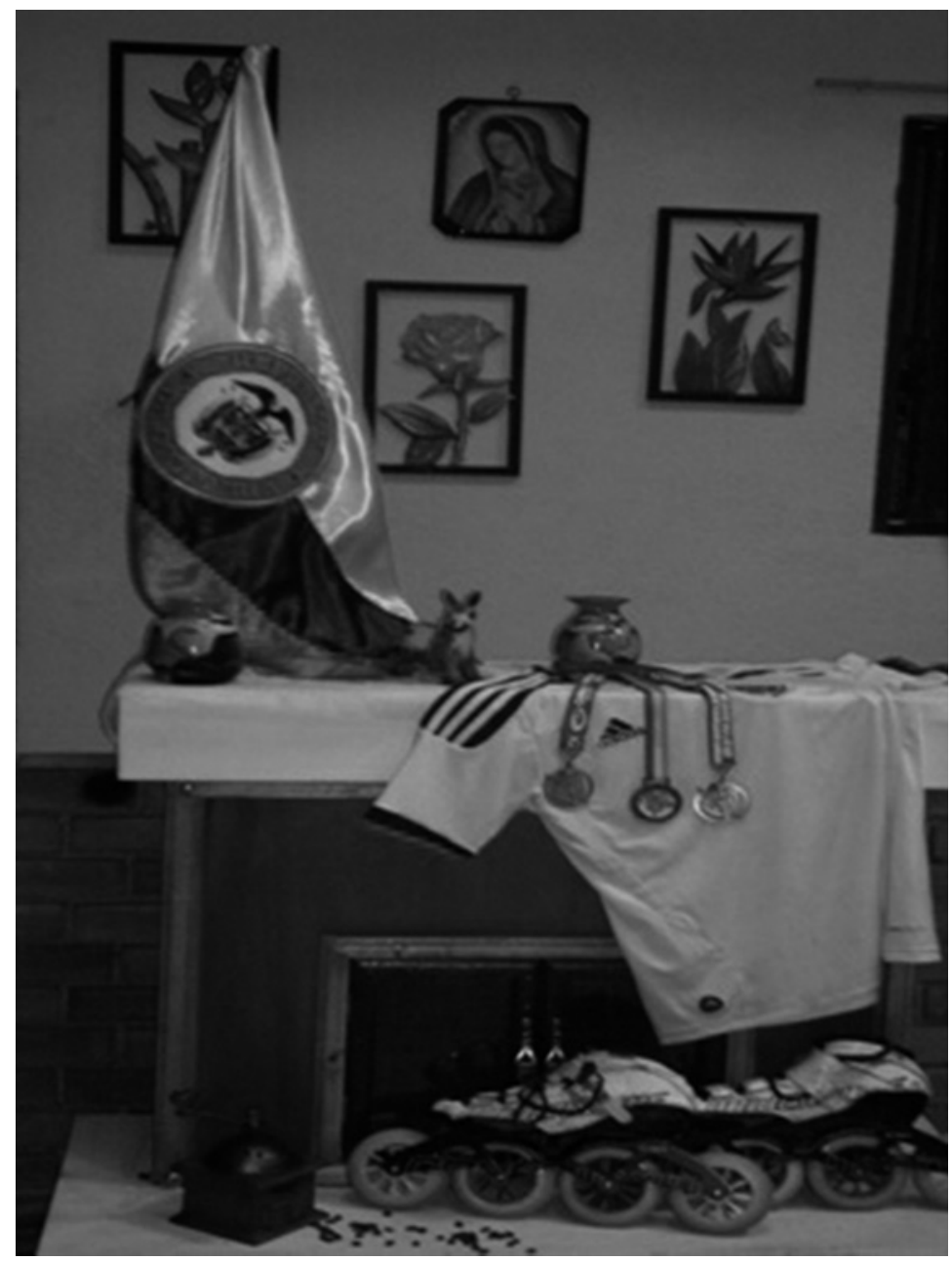

El objetivo del retrato es demostrar lo que es Colombia a través de un objeto, en este caso escogí la camiseta de la Selección Colombia, las medallas y patines para sustentar su importancia, ya que sí las encuentro como significativas, lejos del carácter comercial que puedan llegar a representar. Esto por varios motivos: considero que refleja cómo los colombianos a través del acto de llevar una camiseta demostramos lo importante que son para nosotros los deportes, la alegría y la emocionalidad que produce el ver un partido de la Selección, una carrera de patinaje o de ciclismo. No en vano se produce toda una convocatoria a través de eventos como estos al interior de las familias, de los grupos de amigos y de los diversos grupos sociales. Se produce, en primera medida, un encuentro, seguido de una serie de sentimientos: angustia, alegría, euforia, etc., los cuales nos van configurando alrededor de una colombianidad. Puedo decir, entonces, que este podría considerarse como un elemento común, pues la alegría del fútbol involucra y convoca a los colombianos (Lorena G. $-7 .^{\circ}$ semestre). 


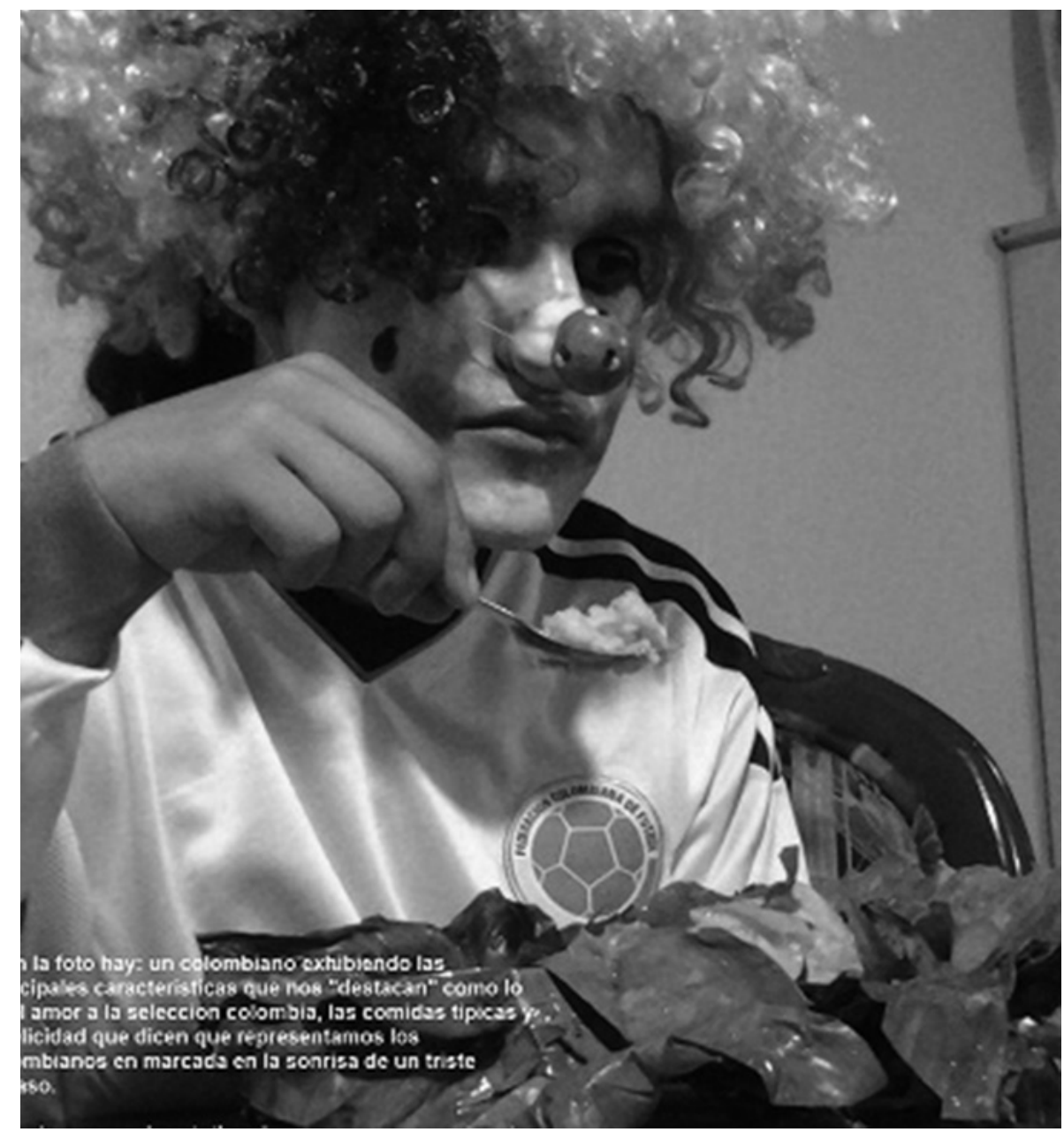

En la foto hay un colombiano exhibiendo las principales características que nos "destacan", como lo es el amor a la Selección Colombia, las comidas típicas y la felicidad que dicen que representamos los colombianos [y que] es marcada en la sonrisa de un triste payaso (Michael $-7 .^{\circ}$ semestre). 
Observemos cómo se complementan y refuerzan estos relatos que mencionan las características de la nación y del colombiano, con algunos fragmentos de relatos producidos en las entrevistas hechas a los estudiantes:

Alejandra F. (1. ${ }^{\mathrm{er}}$ semestre):

Siempre se ha tenido la idea de que el colombiano es el del rebusque [...] Con las cuestiones musicales y con los bailes, por ejemplo, cuando salen representantes de Cali, que bailan, iuff!, genial, salsa, uno queda boquiabierto, porque mezclan la salsa con la acrobacia, que otros países no igualan. Entonces, eso a uno lo hace sentir: "joiga, sí se puede hacer algo distinto y con el baile lo están logrando!". O con la música, o así con ese tipo de cosas, tal vez a uno como que lo inspiran o lo motivan a sentirse tranquilo.

Gisell (1.er semestre):

Lucha, alegría, esas son las dos palabras que se me vienen a la mente cuando pienso en Colombia [...] Yo creo que es como esa verraquera ${ }^{6}$, o sea [...] uno puede conocer gente, no sé, como muy acomodada o algo así, que no ha tenido que luchar tanto como otra persona, no solo de Colombia, sino de muchos países de Latinoamérica, que también se ven situaciones así. Entonces, yo creo que es como esa lucha [...], como, a pesar de todo, esa alegría, o sea [...] pues tenemos problemas, pero todo es fiesta. Es como dejar un poquito aparte como toda esa cosa y no sé, sacar como toda esa euforia.

Edwin (7. ${ }^{\circ}$ semestre):

La manera de actuar, la manera de relacionarse con el otro, las formas en las que uno habla con el otro, o sea, llegamos a una tienda a comprar unas cosas en el Perú y empezamos a regatear, a molestar así, con un peruano y él nos decía: ustedes tienen que ser colombianos ¿ verdad? Son los únicos que vienen y hacen esto, porque nuestra manera [colombiana] [...] la cultura nuestra es un poco más explosiva, más de "hablemos y tratemos de reunirnos acá y, no sé, hagamos algo", como que son aspectos que nos convocan a nosotros. El boliviano es un poco más silencioso, el peruano, de hecho, también. Son personas un poco más reservadas, pues se debe a su cultura. 
Jogser $\left(7 .^{\circ}\right.$ semestre):

De pronto lo más reconocido de Colombia a nivel internacional sería la gente, digamos la capacidad de aguantar y de seguir ahí y esas presiones a las que está sometido el pueblo y los abusos por parte de los diferentes entes, sean gubernamentales, estamentales, a los que está sometido, de cierto modo, también. Eso sería de pronto la capacidad de resistencia también.

Jonathan $\left(7 .^{\circ}\right.$ semestre):

El gringo es como muy fresco, como que saben que Colombia es un país subdesarrollado y que todo es barato y que todos le sirven. El francés es "cómo les ha ido, cómo han estado", hacen más charla. El coreano es mucho respeto. El colombiano [...] de lo que he escuchado, el colombiano es como muy ágil, el que no se va a varar, el que hace de todo, al que se le ocurre siempre la idea, está en la idea de hacer algo, no es tan reflexivo sino más bien de actuar, me parece a mí.

Parte del sentido común nacional entiende al colombiano como creativo, dicharachero, perseverante, fuerte y recursivo. Esto se plasma en los anteriores relatos, en los que se hace énfasis en estos aspectos y formas de ser, incluso cuando se repiten como parte de las características que ellos han escuchado sobre el colombiano, tal como lo hace Jonathan ("he escuchado que el colombiano es"), pero que, de igual modo, incorporan el modo de entenderse y explicarse a sí mismos.

Este factor materializa, como ningún otro, el esquema de estereotipos por medio del cual funciona el engranaje de la identidad nacional $y$, aunque los relatos de los estudiantes no alcanzan a descifrar qué tan a gusto se sienten con este mote (aunque algunos lo ponen entre comillas), se nota su eficacia en la medida en que reproduce y afianza un imaginario social de libre circulación. Según Appiah (2007), para que el estereotipo funcione no es preciso que sus fronteras estén acotadas con firmeza, ni que los criterios de adscripción sean idénticos para todos los usuarios del término, basta con que sean dinamizados desde el exterior y el interior del grupo. El patrón de conducta aplicado desde esta lógica a los colombianos cuenta con una enorme difusión de probada eficacia, visible en cotidianas propagandas mediáticas, chistes, refranes, noticias, canciones y eslóganes que destacan el supuesto genio de lo colombiano.

La presencia de los colores nacionales en las fotografías, especialmente en la camisetas deportivas de seleccionados colombianos, resalta la 
coincidencia con la amplia propaganda oficial y comercial que no solo impulsa la idea de que el colombiano es alegre y luchador, sino que encuentra en las contiendas deportivas, particularmente las de fútbol, otro recurso simbólico para aglutinar a la población.

Desde la segunda mitad del siglo XX, gracias a la transmisión por la radio y la televisión, el deporte ha sido en el país un importante detonante de identidad nacional que ha vinculado a los ciudadanos (Melo, 1989), que ha tejido lazos de hermandad y que ha dado motivos transitorios para exacerbar el orgullo nacional en la mayoría de la población, aspecto que ha sido capitalizado por líderes políticos y dirigentes de Estado que periódicamente impulsan campañas político-deportivas en las que además de posar con los más destacados deportistas instalan grandes pantallas en lugares públicos para transmitir los eventos, organizan desfiles conmemorativos en honor de sus hazañas y atizan el pundonor nacional — mediáticamente - en las más renombradas gestas deportivas, preferiblemente de carácter internacional, pues allí los colores patrios se resaltan y ondean.

En una interesante investigación Andrés Dávila y Catalina Londoño (2003) se preguntaban por qué el deporte tiene la capacidad de construir referentes de identidad nacional. Para responder presentan algunas posibles razones de adhesión (y adicción) al fútbol, entre las que destacan: la sencillez de las reglas de juego, el aspecto campestre y bucólico del campo de juego, la manifestación estética que constituye una contienda, la combinación de habilidades colectivas e individuales, la organización del tiempo y, finalmente, el tratarse de un espectáculo que necesita muchos espectadores. Para los investigadores, desde su profesionalización en la década de los cincuenta este deporte

se convirtió a la vez en espejo y reflejo, alternativa y diferencia, receptáculo y propuesta para esa sociedad atravesada por un conflicto que la desangra y la enceguece. Mientras liberales y conservadores se mataban cada vez con más saña y sevicia, los equipos profesionales eran a la vez competencia, espectáculo, negocio, arte, al menos para núcleos predominantemente urbanos que comenzaban a crecer y a masificarse con gran dinámica (Dávila \& Londoño, 2003, p. 131).

Por ello es entendible que muchos jóvenes narren como eventos significativos de colombianidad aquellos que hayan estado atravesados por su presencia en el estadio o por la mágica comunión con éxitos de la Selección en copas y torneos internacionales vistos por televisión. Parece ser que el deporte y algunos instantes de éxtasis que provoca es 
lo que sensibiliza, despierta, promueve la identificación con la nación propia y ayuda a confirmar el mito colectivo del colombiano verraco, que pese a las adversidades se sabe sobreponer y sale airoso y triunfador. La tenacidad de lo colombiano es casi siempre relacionada con la humildad y el esfuerzo. Los verdaderos colombianos son los trabajadores, la clase popular que "se rebusca" y sobrevive (Diego resalta a los pescadores, su austeridad, laboriosidad y humildad).

Los deportistas que despiertan orgullo son personas tranquilas y de extracción humilde que se destacan en el mundo sin perder su sencillez, que portan con altivez el tricolor nacional. De esta manera, "la gente colombiana" se proyecta en esos hombres y mujeres simples que alguna vez fueron pobres y anónimos y que triunfan con todos los honores, en transmisión directa por las pantallas del planeta entero. Con estos personajes comparten nada más y nada menos que la nacionalidad, aspecto no despreciable que refuerza un nosotros común, en un espacio en el que las disputas con los otros se tramita en los cánones ya no de la guerra, sino del combate simbólico, deportivo.

En resumen, buena parte de los relatos recogidos sobre los estereotipos de nación abren un lugar especial a las supuestas condiciones de fortaleza, tenacidad y júbilo que caracterizan lo colombiano. La algarabía que generan estas definiciones opera, como hemos visto, con cierta eficacia en dos direcciones: como marca identitaria insuflada desde la institucionalidad que distingue de otros mediante la activación de fuertes sentimientos de emoción y pasión hacia lo propio, especialmente desde el deporte; y por otro lado, como recurso cognitivo compensador frente a los avatares e infortunios de la realidad, pues se considera que en lo colombiano están inscritas las condiciones para siempre reponerse, levantarse y resistir a la adversidad.

\section{Las carencias e infamias que nos marcan}

La mayoría de relatos de los estudiantes se establecieron en términos de una identidad nacional negativa, de una colombianidad desprovista de orgullo o valoración positiva y de una serie de características de rechazo a la nación propia. Las carencias, los déficits, las ausencias, la debilidad del Estado y la mediocridad de sus gentes: políticos, clase dirigente, representantes de la Iglesia, sociedad indiferente e inconsciente, principalmente, fueron distintas maneras de nombrar lo que para muchos era propio de Colombia. 
Veamos inicialmente los relatos fotográficos y luego algunos fragmentos de respuestas a las entrevistas:

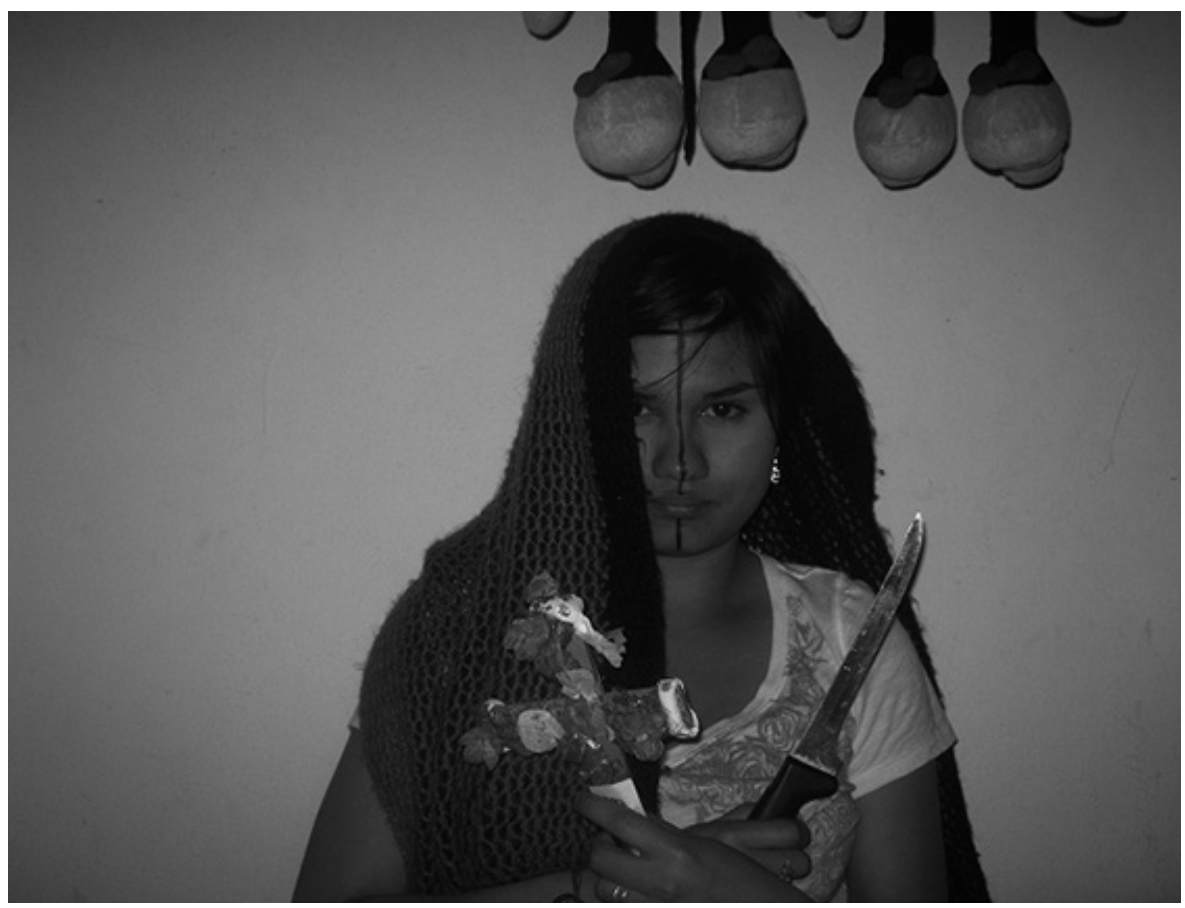

En primera foto lo que trato de mostrar es que Colombia, en parte, es la alianza entre la religión y la violencia desde nuestra historia, en específico desde nuestra conquista, porque al lado de la cruz se impuso la espada y miles de indígenas fueron asesinados o convertidos a una religión que no era la suya y que venía de España, la católica. Desde allí, hemos sido un país muy religioso, en su mayoría católico, y los aspectos morales acompañan a los habitantes de este país. Dicho lo anterior, quise representar un poco la doble moral en la línea por la mitad que hay en mi rostro, porque ser colombiano también es profesar el amor de dios, el perdón, el amor al prójimo e ir a la iglesia, y por otro lado, agradecer que matan guerrilleros, militares, paramilitares y todas las personas que según ellos han pecado y faltan de Dios en su corazón. [...] Hay también falta de reconocimiento histórico y de saber que somos hijos del conflicto y que con él no lograremos cambiar esta sociedad (Alejandra F. - 1. ${ }^{\text {er }}$ semestre). 


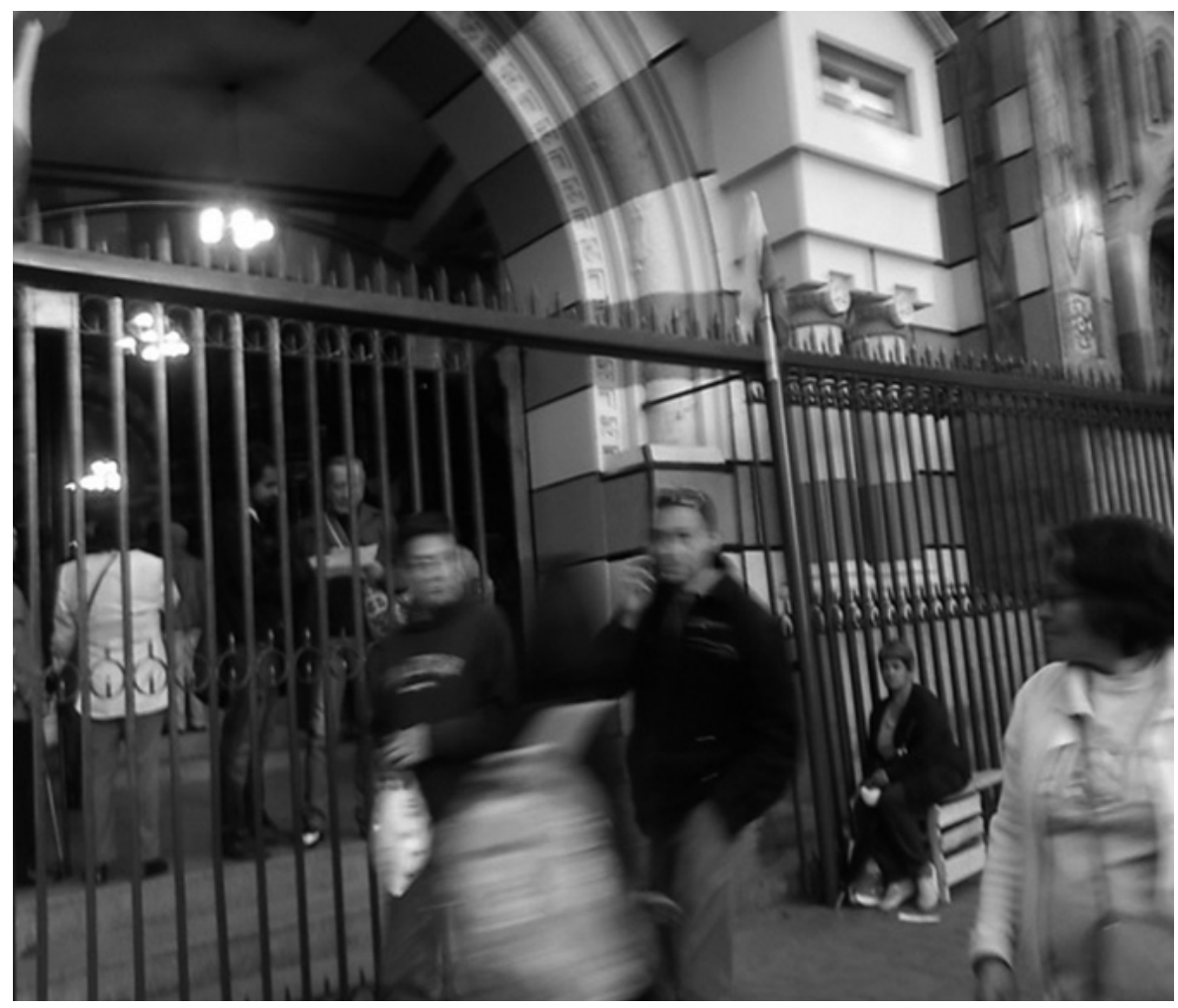

A esta foto la llamo "indiferencia" porque eso es Colombia, ser absolutamente ciego y hacerse "el de la vista gorda" con los demás. En la foto podemos observar cómo al frente de una iglesia hay una pobre compatriota sentada y los demás pasan, hablan, ríen, mientras como ella muchos viven en la miseria. Este es un pueblo al que manejan con fútbol y alcohol. Desde que haya chorro ${ }^{7}$ y Colombia gane en los partidos, el secuestro, el hambre, la falta de educación, los desastres naturales, la corrupción, el robo y las mentiras no importan (Alejandra P. - 1. ${ }^{\text {er }}$ semestre).

$7 \quad$ Aguardiente. 


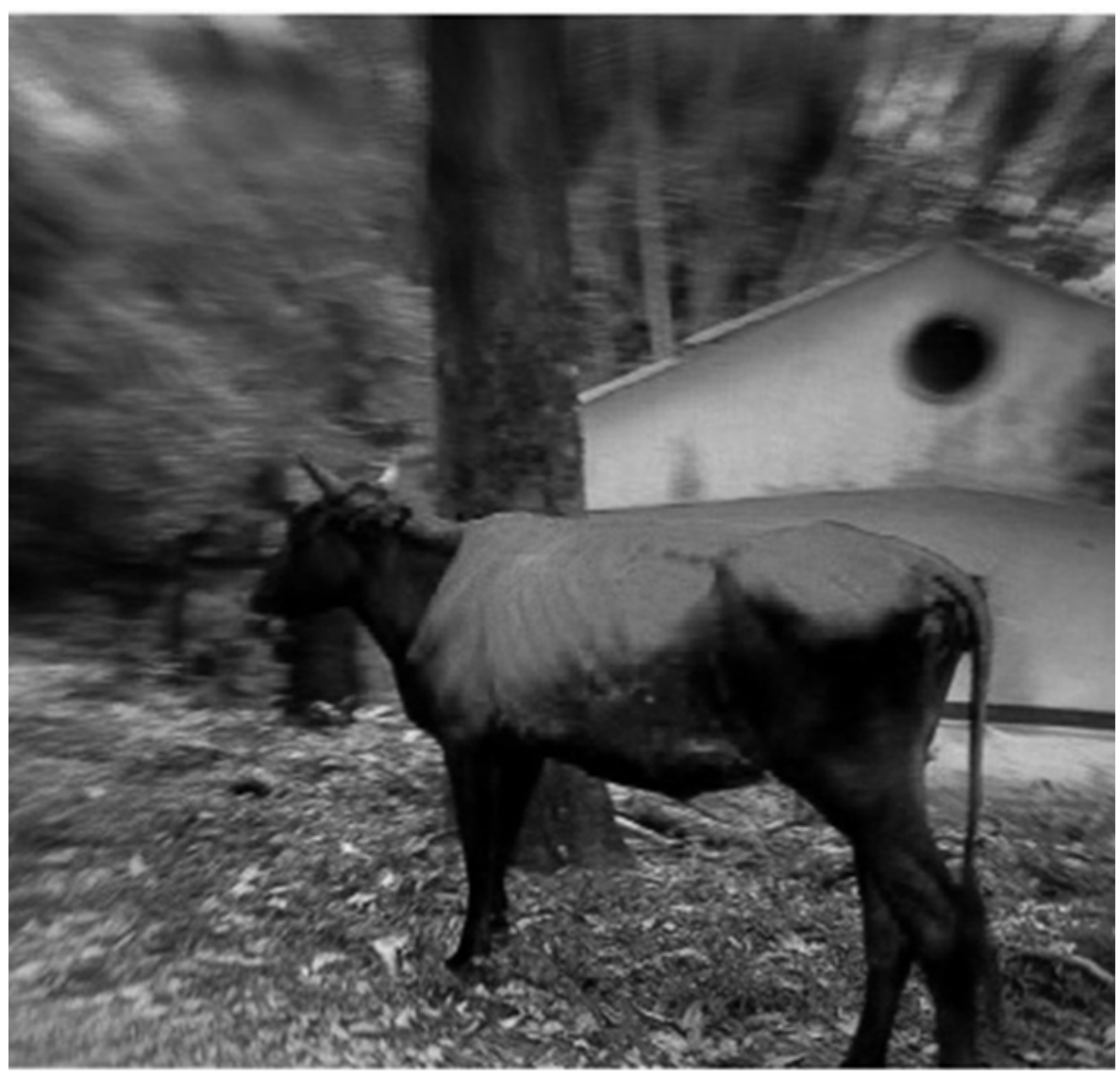

La idea central de la fotografía fue captar a la vaca en medio de la ruinas que deja el desplazamiento forzado por el paramilitarismo en la región, pero, sobre todo, denunciando que es la ganadería un elemento que patrocina la violencia dejada por estos grupos armados en el pueblo colombiano a lo largo y ancho del país. En mi concepto es esta vaca la que condensa toda una historia de horror y sangre que vive Colombia en este conflicto de larga duración (Ignacio, 7. ${ }^{\circ}$ semestre). 


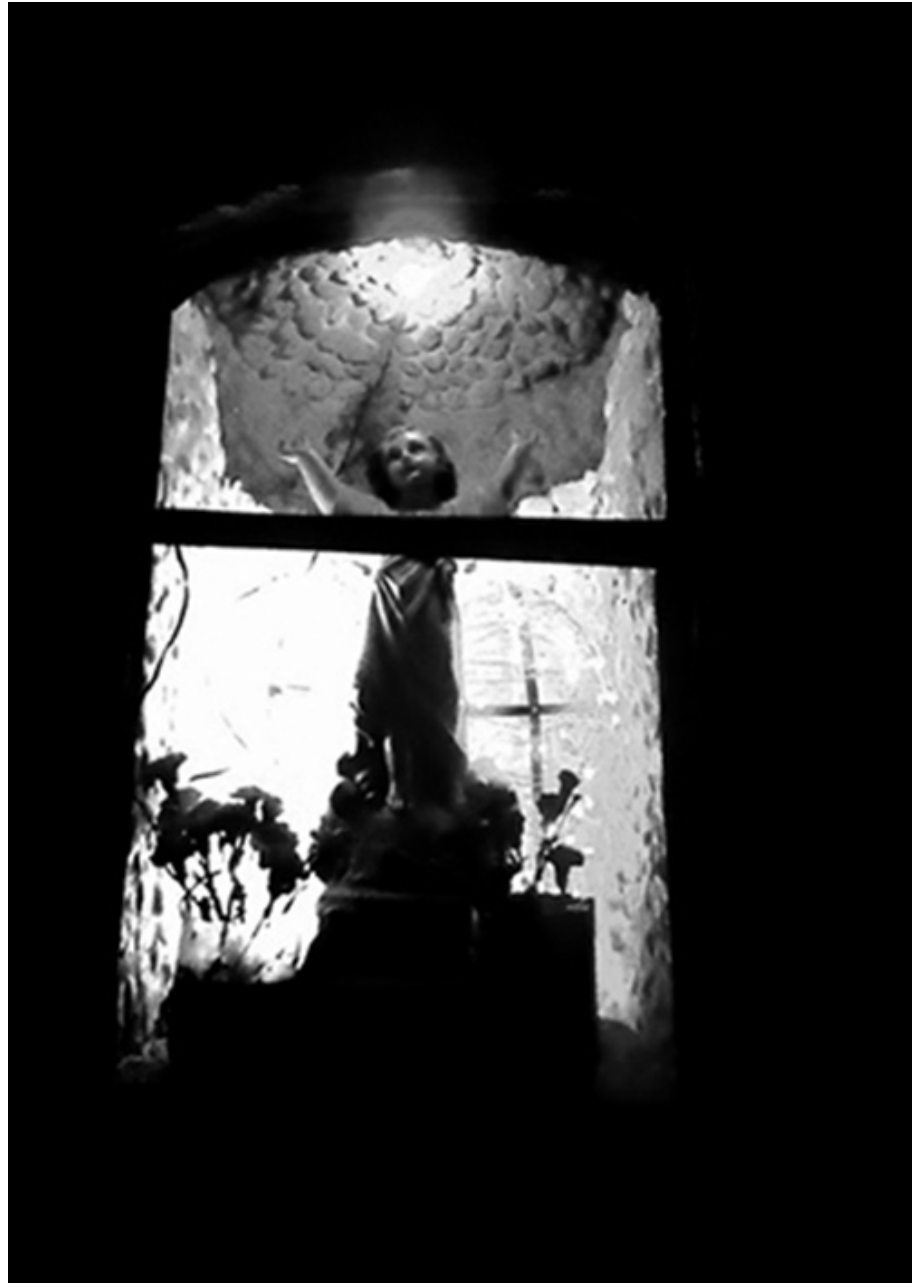

Definitivamente, el país del Sagrado Corazón. Colombia no es más que un cúmulo de tradición, de una [doble] moral religiosa, conservador y atrasado, aunque pretenda ser lo contrario pareciera que siguiera en la Edad Media. Hasta se apedreó a una mujer por ser una "bruja". Creo que este elemento es absolutamente emblemático y representa lo que es Colombia. En la fotografía lo único iluminado es la figura religiosa. Así es como se ha dejado al país, en la absoluta oscuridad, en una negación constante del sujeto, del deseo. Ante la idea del dios cristiano, un supuesto dios de amor, al creer y querer imponer una supuesta verdad que se cree superior se produce y reproduce el machismo, la discriminación, el adormecimiento y estrechamiento de la mente. La Iglesia, que ha influido a través de la historia del país en ámbitos políticos y sociales, es aún altamente significativa en Colombia (Natalia, $7 .^{\circ}$ semestre). 


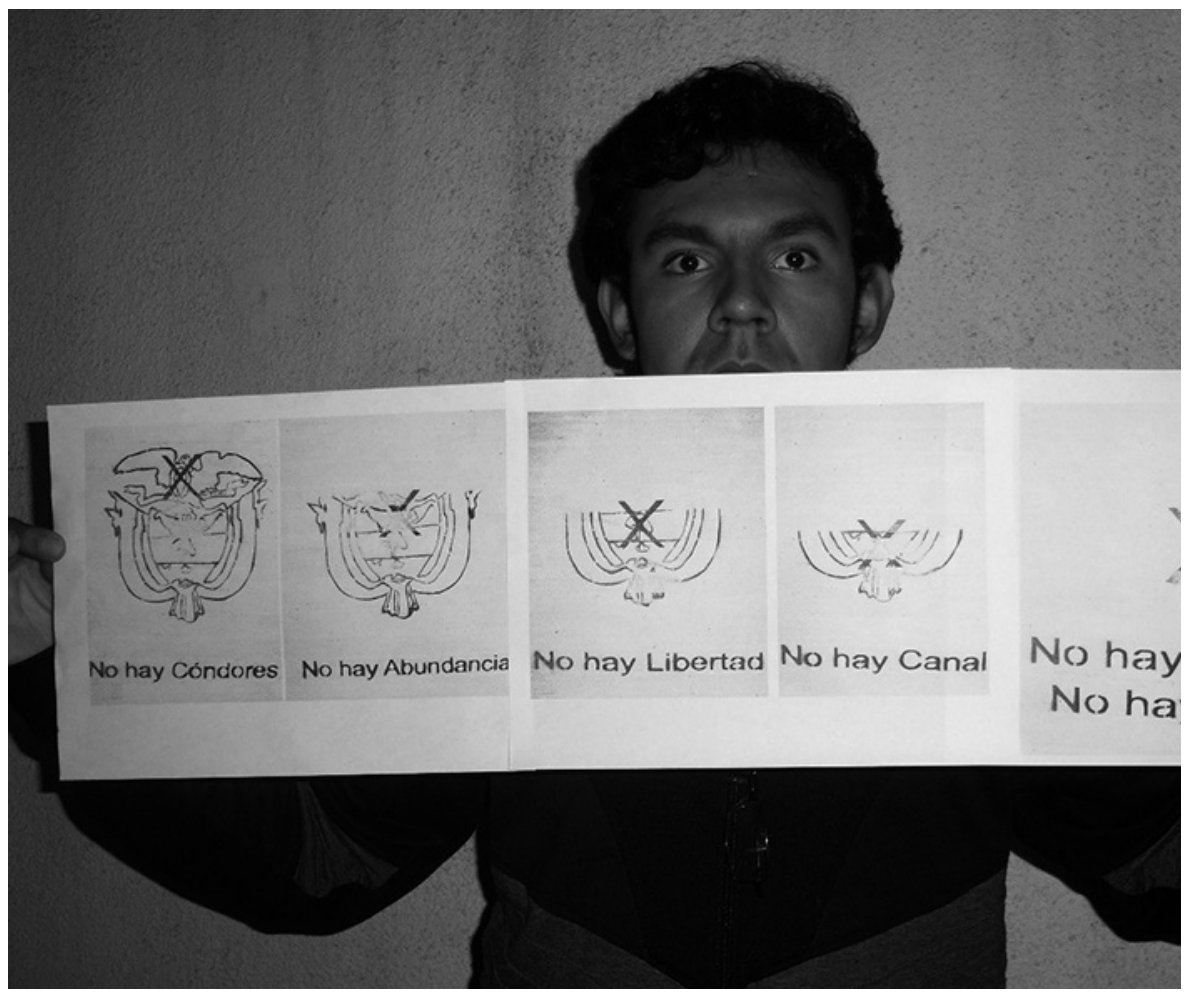

Las imágenes que se presentan en la foto han sido tomadas de un esténcil de libre circulación. En estas, el famoso escudo de Colombia va desapareciendo a medida que se corrobora que lo que este símbolo patrio pretende representar es falso o simplemente mentira. Bien podría ser el himno nacional, la bandera, la orquídea, el sombrero vueltiao, el café y demás cosas que se asocien con este país, los que desaparecen poco a poco. [...] La muerte, la mentira, la corrupción, la ignorancia, la doble moral, el oportunismo, el facilismo, son algunos de los aspectos que se me vienen a la mente cuando pienso en Colombia. [...] Desde hace mucho tiempo que "el amarillo, azul y rojo", "el segundo himno más bonito del mundo", "la puerta de Sudamérica", "uno de los lugares geográficamente más bellos del planeta" han dejado de representar una parte importante dentro de mis afectos (Julián - 7. ${ }^{\circ}$ semestre). 
Estos relatos visuales que denostan de la nación propia fueron reforzados en las respuestas dadas a las entrevistas individuales, veamos algunos fragmentos relevantes:

Juan (1. ${ }^{\text {er }}$ semestre):

Creo que ese es el principal problema de Colombia, que el colombiano es muy callado y muy mediocre, que [si] al colombiano le dicen: "vote por este", bueno; si le dicen: "voten por aquello", bueno; si le quitan educación, bueno; si le quitan salud, bueno; si le quitan el trabajo, bueno; si le suben a todo, bueno. Todo es bueno. Y aprende a vivir en eso y se vuelve mediocre. En Colombia se lucha es por la fiesta, por andar tomando un sábado, un viernes, por eso sí luchamos.

Laura (7. ${ }^{\circ}$ semestre):

Pues evidente que Colombia: narcotráfico, vida fácil, farra en cualquier lugar, pero creo que eso ya venía con lo del narcotráfico en otros tiempos, eso ya como que ha bajado un poco. Pero creo que ese es el referente de los colombianos. Farras, drogas, alcohol, y de las mujeres ni se diga; se conciben como el vagabundo o la chica fácil.

Lizeth $\left(7 .^{\circ}\right.$ semestre):

Creo que a Colombia la caracteriza toda esa violencia de la cual o somos víctimas o somos agenciadores o, simplemente, indirecta o directamente, hacemos parte. Sí, una sociedad sangrienta y violenta, pero, aunque no es lo único que la determina, yo sí creo que hay un referente internacional frente a Colombia, o mundial, y es ser una sociedad tan violenta, una sociedad que tiene un contexto de guerra interna, que tiene problemáticas de derechos humanos muy fuertes y que más que marcarnos a nosotros llegan a marcar esa identidad que se tiene de Colombia por fuera.

La lista de problemas que se exponen para identificar la nación es larga y compleja. Hay inconvenientes políticos, sociales, económicos, culturales que, según los anteriores relatos, caracterizan a Colombia. Es claro que al privilegiar el señalamiento de estos aspectos negativos sobre otros, se da en estos jóvenes la intención de denuncia, de protesta por una situación no deseada ("no es lo único que nos determina", dice Lizeth). Además se puede anotar que no todos atribuyen en la misma medida las debidas causas a estos males estructurales, pues para algunos la injusticia y la violencia pululan por doquier en el ecosistema cultural del colombiano, mientras que para otros la responsabilidad del 
Estado y de los grupos de poder es directa. También es significativa la forma como se implican o se excluyen de las endémicas falencias que señalan. La implicancia personal y la distancia son pistas indicativas para entender la manera como se asumen o no como protagonistas o partícipes de la realidad nacional.

Cabe destacar en estos relatos el lugar que se le atribuye a la religión como aspecto negativo de la idiosincrasia del colombiano, sobre todo en el sentido de haber aportado a perpetuar lógicas de exclusión y autoritarismo. Se resalta así el papel que tuvo y tiene la Iglesia como aliada del poder, al igual que otros mecanismos de distracción o entretenimiento.

Aquello que en el ítem anterior (Colombia es pasión) era resaltado como aspecto característico del colombiano (fiesta, alegría, fortaleza), es visto en este ítem como una cortina que impide la comprensión de la verdadera situación del país, lo mismo que elementos que obstruyen las posibilidades de intervención en procura de mejorar.

Se podría colegir que los estudiantes universitarios, al caracterizar la nación a partir de sus carencias, están decepcionados del país, casi que experimentan un desengaño y una desilusión, pues dibujan el desmoronamiento de un proyecto que gradualmente se cayó ante sus ojos ("desaparecen poco a poco", refiere Julián). El abismo que se abre entre la nación vivida y la nación contada se hace patente en los múltiples adjetivos que usan para criticarla.

Cabe destacar que la violencia como marca de la colombianidad irrumpe en las imágenes y en las palabras de los estudiantes. Ella inunda y copa el nosotros nacional; sin embargo, o mejor por eso mismo, no deja lugar para salidas posibles, no se producen vías para exorcizar esta tragedia. El tono fatalista de los relatos implica el reconocimiento de décadas de guerra que impone una lectura unívoca de la realidad nacional e incluso un tipo de subjetividad política cuyo análisis trasciende los alcances del presente estudio.

La creencia en una identidad nacional basada en las múltiples formas de violencia y en las ausencias, si bien se distancia del tono épico y triunfal que puede aparecer en otros tipos de caracterizaciones, puede estar influenciada por una forma de sensacionalismo mediático que tiende a magnificar las tragedias, lo mismo que décadas de guerra que, según algunos autores (Patiño, 2005), han sido el auténtico imaginario nacional que ha vinculado a los colombianos. La cuestión es identi- 
ficar el nivel de movilización política que ocasiona esta lectura de la identidad nacional, pues, como se observa, el señalamiento de las dificultades copa toda la descripción de lo que Colombia es y no siempre va aparejado de responsabilidades y propuestas de intervención. De manera que esta expresión de las carencias e infamias que nos marcan puede operar como dispositivo inmovilizador y ventura nefasta que obstruye la posibilidad de análisis más complejos de la realidad, lo mismo que trasluce la imposibilidad de actuación personal o social en procurar un orden sociopolítico distinto.

Según Carlos Mario Perea (2009), la violencia cumple una función simbólica al llevarse en sus redes el sentido de la vida colectiva, especialmente en algunos períodos de la historia colombiana. La violencia une la cultura y la política al inmiscuirse en los mundos de la vida de los grupos sociales que construyen sus sentidos e identidades. Aunque pensadas para otra coyuntura histórica, las reflexiones de Perea sirven para explicar la lógica de la violencia que permea el tejido social colombiano, pues el poder político privilegió este recurso como instrumento político, aspecto que los estudiantes universitarios ponen de manifiesto en sus narrativas. Sobre este particular dice el autor:

El hecho de muerte que ingresa al discurso político a finales de 1946 es una renovada versión de la "violencia", en tanto de ahí en adelante se rompe toda mediación institucional capaz de procesar la imagen del Otro inscrita en el ejercicio calculado de la muerte: se obtura la dinámica comunicativa y con ello se destruye el orden democrático. El tema de la división entre las colectividades, siempre presente bajo la forma de una guerra entre espíritus antagónicos, cobra ahora su carácter de real (Perea, 2009, p. 163).

La violencia, sus secuelas y sus múltiples actores, expresan lo más crudo de aquello que nos define como nación, según las percepciones y los discursos de algunos de los jóvenes que se forman como maestros de nuevas generaciones. Si la violencia ha sido una de las modalidades históricas de funcionamiento del Estado (Bolívar, 2003), se entiende que dicha realidad jalone la configuración de un poderoso imaginario que se perfila en muchos colombianos que, como estos jóvenes, han vivido directa o indirectamente toda su vida en medio del profundo y complejo conflicto armado y social y que consideran que configura lo que somos.

Asimismo cabe resaltar que estas carencias son poco interpretadas por estos jóvenes en clave de protagonismo político, pues se impone un 
tono fatalista y moralista del pasado y el presente nacional que, de alguna manera, clausura cualquier posibilidad de intervención y transformación. En los relatos de estos jóvenes la sentencia negativa sobre lo que Colombia es no da lugar a otros horizontes, futuros posibles o al reconocimiento de las luchas que se han dado y se están dando por construir otra nación. 



\section{LA NACIÓN EN LA ESCUELA: AFECTOS, TENSIONES Y SUBJETIVIDAD POLITIICA}

Peste y plaga de la patria es la juventud ociosa, petulante, que alterna entre el café, la mesa y el teatro, que lee lo que no le instruye, que venera y desprecia por moda y adopta la opinión del periódico que lee. Para que el joven merezca el calificativo de educado debe ser atento, respetuoso con todas las personas mayores en dignidad.

(Duarte [1942], citado por Herrera, Pinilla \& Suaza, 2003)

En el capítulo anterior se observaron, en detalle, las características de los imaginarios de identificación nacional en jóvenes universitarios, particularmente en dos vertientes: por un lado, las adscripciones y pertenencias evocadas a propósito de la pregunta por los vínculos con la nación propia, en el que se destacaron la identificación con el territorio regional, con proyectos colectivos de tinte político y con grupos afectivos cercanos a los mismos estudiantes. La otra vertiente ubicada tiene que ver con los estereotipos de nación, entre los que se destacaron aquellos que exaltan las bondades y tenacidad del colombiano, las múltiples expresiones culturales que aparentemente nos unen y el señalamiento de las profundas carencias que nos marcan. En este capítulo la atención estará puesta en la escuela y su relación con la identidad nacional. Esto es, de qué manera la escuela o, mejor el registro escolar ${ }^{1}$ (Kriger, 2010) contribuye a configurar y re-editar formas particulares de identificación con la nación propia.

Durante el siglo XIX y la mayor parte del siglo XX para los países latinoamericanos fue determinante el papel de la escuela en la configuración de la identidad nacional (Romero, 2004; Lewkowicz, 2005; Carretero, 2007; Bertoni, 2001; Rojas, 2008; Finocchio, 1993; Tenti, 2007; Ruiz, 2011). En las nacientes naciones los Estados nación utilizaron los sistemas educativos para forjar en los ciudadanos en ciernes los sentimientos, las actitudes y los comportamientos necesarios para su perpetuación y fortalecimiento. La celebración de las efemérides, las izadas de bandera, la entonación de himnos, los desfiles cívico-militares y las "bandas de guerra" escolares fueron algunos de los dispositivos

\footnotetext{
1 El registro escolar (Kriger, 2010) como categoría analítica que permite identificar elementos ideológicos y culturales, en principio, de uso escolar, pero igualmente asimilados, de manera amplia, por la sociedad en sus distintos ámbitos (museos, parques temáticos, medios de comunicación, actos protocolarios, entre otros), para reproducir y recrear, de diferente forma, idearios nacionalistas. Es clave entonces comprender que el registro escolar trasciende la escuela misma.
} 
más utilizados para inculcar en los niños una especial devoción hacia la patria (Kriger, 2010; Carretero \& Kriger, 2004; Kriger y Carretero, 2006). Estos ritos, creados primero para la milicia y adaptados luego para la escuela, permearon gradualmente las otras esferas de lo social como eficiente mecanismo pedagógico del Estado, pues en el proceso de construcción de las naciones las clases en el poder convirtieron su propia noción de nación en un ideal, en un valor supremo, y se preocuparon por que la totalidad de la población así lo viera. La escuela prestó un leal y eficiente servicio al respecto.

El proceso de adquisición de un sentido de pertenencia de los ciudadanos hacia las naciones no fue un hecho natural, más bien fue posible gracias a su reiterada y sistemática participación en rituales y prácticas simbólicas, lo que Hobsbawm y Ragner (1983), en su momento, denominaron la invención de la tradición:

La "tradición inventada" implica un grupo de prácticas, normalmente gobernadas por reglas aceptadas abierta o tácitamente y de naturaleza simbólica o ritual, que buscan inculcar determinados valores o normas de comportamiento por medio de su repetición, lo cual implica automáticamente continuidad con el pasado. De hecho, cuando es posible, normalmente intentan conectarse con un pasado histórico que les sea adecuado (p. 8).

La escuela contribuyó, desde sus prácticas pedagógicas y desde el registro escolar, a inventar una tradición nacionalista que la convirtió en uno de los escenarios favoritos para ritualizar la pertenencia a una comunidad que exigía una fuerte carga emocional.

Sin embargo, hoy se habla de crisis de la escuela, hoy ella replantea su lugar en la sociedad y su misión con las nuevas generaciones (Lewkowicz, 2004; Mejía, 2006; Meirieu, 2004). Esta institución, que nació con la modernidad al servicio del Estado nación, es tensionada en estos tiempos por varias exigencias: responder a la vieja solicitud de conservar los rituales propios de la invención de la tradición; transmitir versiones didácticas de conocimientos científicos (Gimeno, 1999); ajustarse a las exigencias de la mundialización de la cultura, en el sentido de impartir saberes y generar capacidades proclives al cosmopolitismo y al universalismo; forjar las habilidades y competencias necesarias que los ciudadanos del contemporáneo mundo laboral y político requieren (Apple, 2002), y dar respuesta a la crisis social de los sectores marginales de la sociedad, reteniendo la mayor cantidad de población durante el mayor tiempo posible, y en este sentido, solventar lo que 
otras instituciones del Estado no pueden o no quieren atender (Tenti, 2007). El ideal decimonónico de una escuela al servicio exclusivo de la patria y de la fábrica se desmorona.

Para algunos teóricos, "en la actualidad pareciera que los objetivos centrales dirigidos a la formación de identidad y los dirigidos a la formación de conocimientos históricos se encuentran en creciente contradicción" (Carretero \& Kriger, 2010, p. 61), contradicción no siempre fácil de resolver y que para esta época, desde las voces de los estudiantes universitarios de primer y séptimo semestre participantes del presente estudio, pareciera cristalizar en la toma de distancia de la concepción romántica que funde la actividad escolar al interés de la nación.

En procura de establecer precisiones conceptuales es importante acotar qué se entiende por escuela y educación. De acuerdo con Vasco, Martínez y Vasco (2008), la escuela es un tipo de institución social, bien sea estatal, pública o privada, laica o confesional, encargada de la formación e instrucción formal. La educación, por su parte, se entiende como el proceso deliberado de formación de un saber específico, proceso dirigido, diseñado y, en parte, implementado por el Estado.

Entendemos la educación como una práctica social compleja, situada en las prácticas sociales emprendidas en todas las culturas como prácticas formativas de las nuevas generaciones por necesidades de supervivencia, pero que... solo adviene por una institucionalización específica de esas prácticas sociales que ocurre hacia el siglo XVII en el centro de Europa alrededor de la escuela pública y que se ha ido extendiendo a todos los países del planeta (Vasco, Martínez \& Vasco, 2008, p. 110).

Pese a que esta acepción marca distancia con la idea que asume la educación como un proceso general y abstracto concomitante a la sociedad o presente aleatoriamente en las prácticas de socialización que suceden en todos los ámbitos de la realidad, se reconoce que el sujeto retoma aprendizajes a lo largo de sus experiencias vitales, en su contacto cotidiano con la sociedad, de tal suerte que la educación, aunque es propia de la escuela, también sucede en otros contextos, espacios, instancias. Afirmar la especificidad de la escuela no implica negar la posibilidad de que los individuos generen aprendizajes en otros escenarios sociales o por otras fuentes. Además, ateniéndonos a la noción dada de registro escolar, conviene anotar que algunas instancias sociales re-producen y re-crean el discurso escolar bajo distintas 
modalidades e intereses, para el caso, en función de transmitir ciertos imaginarios respecto a lo que debe ser la identidad nacional ${ }^{2}$.

Los datos recopilados permitieron organizar el desarrollo de este objetivo en una línea temporal que se divide en tres partes: la nación en la escuela que se recuerda y la nación en la escuela que se proyecta. En la primera se agrupan los relatos de los estudiantes referidos a sus memorias sobre la forma como vivieron la identidad nacional en la escuela. En este grupo resaltan dos aspectos: la nación en la escuela que no se quiere (que recuerda una educación tradicional, acrítica e inculcadora de sentimientos nacionalistas) y la nación en la escuela que se valora (que se distancia de los discursos oficiales). Por otro lado, la nación en la escuela que se proyecta da cuenta de relatos y testimonios que posicionan a los estudiantes frente al papel deseado de la escuela respecto a la identidad nacional y la constitución de sujetos. De este acápite se desprenden dos aspectos: la nación en la escuela para el compromiso social (que reivindica la conciencia crítica y la enseñanza de la "verdadera historia", casi siempre de corte alternativo frente a los contenidos tradicionales y hegemónicos) y la nación en la escuela para la conciencia planetaria (que propende por el cuidado de la humanidad y de la naturaleza).

\section{La nación en la escuela que se recuerda}

Las narraciones que el sujeto hace sobre su vida son posibles gracias a que recuerda, a que hace memoria. "Las narraciones que hacemos de nuestra vida son posibles gracias a que recordamos; a su vez, en las narraciones que vamos configurando se reinterpretan las vivencias que se han sedimentado en la memoria" (Ruiz \& Prada, 2012, p. 61). La memoria es la mediación con el pasado, atravesada por el tiempo, con sus recuerdos y sus olvidos. La memoria nos constituye como seres humanos y representa un ingrediente fundamental de los procesos de identificación social y política. Tanto en lo social como en lo personal, somos, en buena medida, lo que recordamos de lo que somos. No en vano se vienen adelantando en las últimas décadas importantes luchas por la memoria (Jiménez \& Guerra, 2009; Carretero, 2007), pujas por

2 En Colombia existe una arraigada práctica que no está estipulada en ninguna normativa: es casi obligatorio que en la inauguración de actos protocolarios de índole académico, civil o deportivo se escuche y se cante el himno nacional a manera de introducción o apertura de los eventos. Además, durante y después del gobierno de Álvaro Uribe Vélez (2002-2010) se volvió usual que en estos actos tal rito sea acompañado con el gesto, igualmente solemne, de la mano derecha en el corazón. 
establecer versiones legítimas de acontecimientos polémicos y conflictivos de los pasados recientes nacionales, pues es evidente que los intereses y conflictos del hoy condicionan, en parte, las lecturas que se hacen sobre el pasado.

Al decir de Herrera y Ramírez (2009), "la memoria se constituye en una mediación que permite la estructuración de esquemas, patrones mentales y hábitos ligados a las significaciones culturales de los grupos de los cuales hacen parte los individuos, contribuyendo a la constitución de identidades" (p. 28). En este sentido, las memorias escolares, o mejor, la nación en los recuerdos de la escuela de estudiantes universitarios, presenta varias aristas en las que confluyen distintos proyectos en pugna, es decir, hablar de lo que han sido las experiencias escolares es poner sobre la mesa concepciones de mundo y de ser humano cuyo análisis requiere establecer relaciones con las versiones y los contextos que las han configurado. La nación en la escuela que se recuerda no solo es leída desde opciones presentes, sino que es claramente valorada desde lo que se cree debe ser la sociedad, la escuela misma y, para el caso de la presente indagación, la nación en relación con la enseñanza de las ciencias sociales (campo en el que se forman los estudiantes participantes).

Se trata de darle contenido al cruce entre la historia escolar recordada y la historia personal vivida (Ruiz, 2011), aspecto en el que las pretensiones escolares son confrontadas con juicios de los mismos jóvenes en la distancia, ya que "la utilidad simbólica y práctica que los estudiantes le atribuyen a la historia aprendida en la escuela depende no solo de lo declarado en el presente, en sus relatos, sino también de la conciencia de lo que pueden hacer o no con ello en el futuro" (p. 204). En este punto, como se verá, irrumpe una clave de lectura que distingue entre una nación aprendida y un Estado vivido.

Estas voces con deliberaciones y decisiones que se introducen en el deber ser remiten al concepto de moral ${ }^{3}$, más concretamente a la connotación moral dada a las narrativas, aspecto que combina de forma compleja elementos ideológicos, afectivos, valorativos y ficcionales (Ruiz, 2011). Los testimonios de los jóvenes participantes del presente estudio evidencian esta inclinación, ya que sus testimonios están cargados de

3 Según Charles Taylor (1989), la moral trata de las cuestiones acerca de qué es una vida plena, qué vida merecer ser vivida "o qué clase de vida satisfará mejor la promesa implícita en mis particulares talentos, o la demandas que alguien pudiera hacer con respecto a mis cualidades, o qué es lo que constituye una vida rica y significativa a diferencia de una vida dedicada a cuestiones secundarias o a trivialidades" (p. 29). 
juicios hacia lo que vivenciaron, o mejor, hacia lo que recuerdan de lo que vivieron.

\section{La nación en la escuela que no se quiere}

Pese a las grandes y profundas transformaciones acaecidas en el siglo XX (Hobsbawm, 1994) y que en parte impactaron los sistemas educativos, buena parte de las memorias escolares que bordean la primera década del siglo XXI, materializada en las voces de los estudiantes que participaron en esta investigación, echan mano de situaciones y anécdotas que hablan de una enseñanza patriotera, nacionalista y defensora a ultranza de la iconografía republicana. Cabe señalar que la mayoría de jóvenes participantes coincidieron en señalar, en sus referencias a la historia aprendida en la escuela, desde una perspectiva abiertamente crítica, la persistencia de una educación al servicio de intereses nacionalistas. Los siguientes tres testimonios ejemplifican lo dicho:

Manuel ( $7 .^{\circ}$ semestre):

Por el lado del colegio, creo que fue muy relevante eso de lo patrio, porque la enseñanza de Ciencias Sociales era muy limitada. Entonces todos aprendimos de Simón Bolívar y aprendimos de ciertas fechas y aprendimos del territorio con sus ríos y sus montañas. Entonces, aprender de gentilicios, de los de aquí qué son y los de allá qué son y todo eso. Pero esto es muy limitado, tan limitado que cuando se trataban de meter otros conceptos diferentes era muy difícil.

Julián $\left(7 .^{\circ}\right.$ semestre):

Cuando escucho la palabra Colombia lo primero que se me viene a la cabeza es de una vez el mapita y el escudo [en tono despectivo]. Es una imagen que me queda del colegio. El mapa con la bandera ahí, como coloreado. La idea de esa nación y de quererla se fue diluyendo a medida que fui pasando la carrera y encontrando otros rollos, otros cuentos; como que el mundo es mucho más complejo que una sola nación. [...] La gente que ama la nación es ilusa, esa es la palabra que usaría, porque deben creer que aquí somos una nación o una unidad y a mí me resulta imposible pensarlo. Que la gente viva en la ilusión de que Colombia es una sola $y$ de que todos vamos juntos, me parece equivocado totalmente.

Ángela (1. ${ }^{\text {er }}$ semestre):

La visión de Colombia - tema que tal vez parezca simple- es demasiado confuso. La mayoría de ciudadanos se dejan llevar por 
su identidad nacional, lo cual hace que se pierda el valor de un país en la realidad, pues es muy simple caracterizarlo o describirlo según los criterios culturales que equivocadamente nos han enseñado durante nuestra vida escolar, tomando los símbolos patrios y ese ferviente nacionalismo, para estar orgullosos de una nación.

Aunque han sido abundantes las críticas de los teóricos a la enseñanza nacionalista, su presencia persiste, tal y como lo constata la crítica que hacen estos estudiantes a la historia que les enseñaron recientemente en la escuela. Aquí, estos retazos de recuerdos sobre experiencias escolares con celebraciones de efemérides, mención de próceres y simbolismo patrio ("Simón Bolívar", "ciertas fechas", "el mapa con la bandera") no se refieren a un pasado lejano, sino a una escuela vivida en tiempo reciente que prescinde de acontecimientos sociales complejos y que es excesivamente personalista y en esa medida heroizante, sacralizadora y teleológica.

Estos jóvenes, que no superan los 20 años, rememoran sus experiencias recientes y hacen visible una escuela que consciente o inconscientemente busca provocar sentimientos de adhesión a la idea de un pasado nacional glorioso e incontestable. Así lo muestra el testimonio de Ángela en el sentido de indicar, casi denunciar, la relación entre la formación escolar y un ferviente nacionalismo, Julián al considerar ilusos a los que aman la nación y Manuel al señalar lo limitado de sus aprendizajes patrios. Esta toma de distancia de los propios jóvenes de la perspectiva autocelebratoria, coincide con la postura de la mayoría de analistas sociales que recalcan el servicio que presta la escuela a la idea de un proyecto esencialista de nación (Pozo, 2000; Pérez, 2000; Kaufmann, 2006; Carretero \& Voss 2004; Romero, 2004, Carretero, 2007; Kriger \& Carretero, 2006; Ruiz, 2011).

Aunque parecen reducirse, en la formalidad de los textos escolares, las pretensiones abiertamente nacionalistas ${ }^{4}$, debido entre otras cosas a la pérdida del poder del Estado en la elaboración de manuales, en la

4 A manera de ejemplo, el texto de amplia circulación en Colombia Nuevo Identidades 7, de la editorial Norma (Cortés et al., 2005), dedica pocas y desapegadas páginas al estudio de la nación, además maneja una noción ambigua y contradictoria de la misma al afirmar que "el Estado es posible en la medida en que consolida un grupo social cuyos individuos tienen sentido de integración y de pertenencia y una cultura común, es decir, una misma lengua, unas creencias y tradiciones comunes, factores que en conjunto conforman el concepto de Estado-nación" (p. 218). Aunque no es objeto del presente estudio, cabe anotar que en las últimas décadas los libros de texto colombianos han privilegiado una extensa información enciclopédica y diacrónica en sus contenidos que enfatizan especialmente la historia y la geografía occidental. Para un mayor análisis de los estándares para la enseñanza de las ciencias sociales en el país véase Arias (2005). 
formación y en la elección del profesorado (López Facal, 2000) y en las adecuaciones de los sistemas públicos escolares a las demandas del mundo globalizado, los rezagos patrioteros funcionan implícita o explícitamente. En términos de este autor, existe una desadecuación entre lo enseñado y lo vivido, ya que transitamos un tiempo en el que "buena parte de la enseñanza escolar perpetúa un currículo residual pensado en y para otros tiempos" (p. 20). Este desajuste aflora en los testimonios de los jóvenes que dijeron vivir este tipo de formación ("fue muy relevante eso de lo patrio" dijo Manuel) aunque el currículo prescrito, los manuales escolares y los lineamientos curriculares nacionales no buscan abiertamente esas adscripciones.

Cuando Julián afirma que "lo primero que se me viene a la cabeza es de una vez el mapita y el escudo" deja ver que la incorporación de símbolos patrios en la escuela ha sido naturalizada y las prácticas que corresponden a esta dinámica hacen parte de la cotidianidad escolar, que se mantiene y se reproduce, incluso por fuera de los contenidos curriculares, paradójicamente en los tiempos de crisis del Estado nación $^{5}$. Para la gran mayoría de escuelas las efemérides operan como una especie de articulador del calendario escolar, en el sentido de pautar los tiempos y organizar buena parte de las celebraciones y las fiestas importantes junto a las conmemoraciones religiosas ${ }^{6}$. Tomando distancia crítica de este tipo de rituales, Manuel y Julián señalan:

Julián $\left(7 .^{\circ}\right.$ semestre):

El famoso escudo de Colombia va desapareciendo a medida que se corrobora que lo que este símbolo patrio pretende representar es falso o simplemente mentira. Bien podría ser el himno nacional,

5 Varios autores han caracterizado la manera como los actuales Estados nación se han reconfigurado al tenor de las dinámicas internacionales, bien desde una perspectiva social y cultural (Ortiz, 2004; Hobsbawm, 1994), desde la arquitectura de subjetividades contemporáneas (Bauman, 2001), o desde una lógica política que otorga protagonismo a entes multilaterales en desmedro de las posibilidades de maniobra de los dirigentes nacionales (Santos, 2005).

6 En Colombia, en los colegios, son de obligatorio cumplimiento las celebraciones del 20 de julio (Día de la Independencia), del 7 de agosto (Batalla de Boyacá) y el 12 de octubre (Día de la Raza). Además, dependiendo de la orientación del colegio o la voluntad de las directivas, se pueden conmemorar algunas fiestas religiosas en junio (Corpus Christi y Sagrado Corazón), en julio (San Pedro y San Pablo), en agosto (Asunción de la Virgen) y eventualmente en diciembre (Inmaculada Concepción). "La conmemoración patria del 20 de julio que se celebrará en todos los establecimientos educativos de la ciudad, el último día hábil anterior a tal fecha, con actividades culturales programadas por las directivas de los planteles y la participación de la comunidad educativa. [...] Las demás fiestas patrias se celebrarán de conformidad con lo que las directivas del establecimiento organicen para tal efecto" (comunicado de la Secretaría de Educación de Medellín para el calendario lectivo 2013). Fuente: http://www.mineducacion.gov.co/cvn/1665/w3article-315163.html (Consultado: 14-02-2013). 
la bandera, la orquídea, el sombrero vueltiao, el café y las demás cosas que enseñan en la escuela y que desaparecen poco a poco.

Manuel ( $7 .^{\circ}$ semestre):

Cuando uno se da cuenta de esas construcciones, de dónde es que vienen, esa idea de lo nacional pues imiércoles!, o sea, en esa idea de lo nacional han participado todos menos nosotros [...] Esa construcción ha sido más de elites [...] Incluso puedo decir que esa idea de los simbolismos que hay [...] uno se pone nada más a escuchar el himno y dice: "¿qué es esta mierda?" y uno cantándolo en el colegio [...] gracias a él tanto tiempo uno así, que el himno, que la bandera. Entonces uno dice: "bueno, ¿quién hizo el himno?, ¿cómo se hizo la bandera?, ¿por qué la cumbia se muestra como algo de todos?". Sí, esos simbolismos que se dan para mostrar una idea de todos.

Nótese que estos jóvenes no aceptan y no comparten las memorias de una escuela patriótica (promotora del respeto de los emblemas y los símbolos patrios más tradicionales) o, si se quiere, patriotera (esencialista, sacralizadora de dichos emblemas). La apelación a la nación no genera en ellos un sentido de adhesión, esto se puede ver mediante narrativas que indican la decadencia, el desvanecimiento de elementos identitarios que vinculan la sociedad nacional y la escuela: "lo que va desapareciendo", lo que "es falso y más de las élites". Ambos jóvenes dan cuenta de proyectos ilegítimos, en los que no se sienten incluidos, en los que "han participado todos menos nosotros". Estos relatos ponen de manifiesto la existencia de prácticas escolares rutinizadas que enlazan idearios nacionalistas, pero que adicionalmente permiten reconocer el uso político que perseguían, por eso Manuel culpabiliza al colegio: "gracias a él tanto tiempo uno así".

El desconcierto, la perplejidad y el darse cuenta del engaño (" ¿qué es esta mierda?") patentizan la presencia del currículo residual, currículo no prescrito pero vivido, que quizá habla de una escuela cuyo horizonte y razón de ser no son claros, o de la añoranza en las directivas educativas de una identidad colectiva que ya resulta difícil reconocer, o de la búsqueda en las élites de un nosotros en medio de unas instituciones desfondadas o ausentes, o un poco de todo ello. "Entonces - dice Ignacio Lewkowicz (2004) - no estamos en la ruina de las instituciones, en la crisis de las instituciones, sino en el agotamiento de su condición estatal metainstitucional" (p. 175). Agrietamiento que coincide, según algunos autores, con la puesta al día del tema mismo de la identidad: "hablamos de identidad debido al desmoronamiento de esas institucio- 
nes que [...] constituyeron durante muchos años las premisas sobre las que se construyó la sociedad moderna" (Vecchi, 2010, p. 19). Es decir, si hoy nos interroga el tema de la identidad nacional y son posibles preguntas como "¿quién hizo el himno?, ¿cómo se hizo la bandera?, ¿por qué la cumbia se muestra como algo de todos?", es porque el lugar de las instituciones y del Estado no es el mismo, porque ya no configuran las identidades que hace unas décadas no admitían mayores cuestionamientos o sospechas.

Hemos afirmado que el discurso nacionalista sobrevive en la escuela contemporánea de múltiples y variadas formas, pero, por otro lado, como también se alcanza a notar en los testimonios, esta pervivencia de los esfuerzos por generar identidad nacional no llega a ser exitosa, estos elementos no son recordados por los jóvenes con ilusión ni alegría, y mucho menos lo consideran una tarea pendiente por realizar. Por el contrario, es evidente una mirada reticente hacia esa escuela promotora de sentimientos nacionalistas. Esta tendencia está presente en la gran mayoría de estudiantes entrevistados. Veamos algunos testimonios relevantes, al respecto:

Alejandra (1. ${ }^{\text {er }}$ semestre):

La realidad hace que uno pierda el encanto por lo que es Colombia, que le pintan a uno un paisaje desde que está en el colegio. ¡Ahh!, es que Colombia tiene montañas y climas diferentes [...] y muchos paisajes. Eso no [...] Le pintan una visión muy fantástica de lo que es Colombia, entonces, uno después se enfrenta con otra realidad.

Brayan (1. ${ }^{\mathrm{er}}$ semestre):

La escuela sirve para eso. Uno para qué necesita saberse el himno, creo que lo escribió Rafael Núñez, conservador, y la gente ni sabe qué significa el himno. Por ejemplo, a mí me da pereza buscar en el diccionario qué significa inmarcesible júbilo inmortal, lo de la bandera, lo de la plata, el amarillo, azul y rojo, una explicación tan pendeja que al final ni se sabe por qué le pusieron esos colores. Bobadas. ¿Para qué aprenderse todo ese tipo de cosas? Es más, como cultura general, pero no nos afecta en mucho. Uno sentirse representado por el color de una camiseta, por el color de una bandera, por el himno, son bobadas no más.

Alejandra (1. ${ }^{\text {er }}$ semestre):

Yo pienso que es importante enseñar lo real, no lo fantasioso, como a muchos nos pasó. Que Colombia es un país hermoso y 
tiene no sé cuántas especies de pájaros y todo eso [...] y uno era feliz y dichoso, pero no es la realidad. Nos enseñan eso, pero no hay ni la mitad de lo que era.

Jonathan $\left(7 .^{\circ}\right.$ semestre):

En el colegio a uno le habían dicho lo mismo de siempre: el himno es el segundo más bonito, y la bandera, pero cuando uno llega a la universidad se entera de muchas cosas, que el escudo está mal diseñado porque hay muchas cosas que ya no están, que lo que simbolizaba en ese tiempo ya no existe, que la bandera tenía cierto significado pero no [...] Con el himno es igual que rezar, uno no sabe ni qué está diciendo. Es como un adoctrinamiento.

Frases como la de Brayan: "¿para qué aprenderse todo eso tipo de cosas?" o "no es la realidad" de Alejandra, confirman la distancia explícita que marcan estos jóvenes con la representación tradicional de la nación. Probablemente esta presencia abiertamente impugnada de los ideales románticos y nacionalistas es síntoma de la tensión que configura los discursos y las prácticas escolares, que no es monolítica y que está abierta a otras corrientes y a fisuras que filtran otras voces, pero también es síntoma de la asimilación crítica que los estudiantes hacen de lo que reciben de su educación, en la que los trazos de su identidad nacional presente no son reflejo mecánico de su pasado inmediato, sino que depende de las herramientas culturales que tienen y van adquiriendo para leer estas experiencias; además, de la forma como han construido sus opciones ético-políticas, las lecciones de estas experiencias se desarrollan o se eliminan.

La identidad no es un estado o un ejercicio estático, sino que es dinámica y fluctuante. Por ello Alejandra dice: "uno después se enfrenta con otra realidad", al hacer alusión a la modificación de su percepción del entorno y la distancia que guarda respecto a la valoración de lo recibido en la escuela. Diferencia de percepción que es expresada con frases como "son cosas que ya no están", que "ya no existen", al decir de Jonathan. Cosas que tal vez aún existen, que todavía están pero que ahora no hacen parte de la cosmovisión y de los referentes valorativos presentes de quien los señala. Además, es posible observar que no deja de notarse cierta nostalgia ("cosas que ya no están", "no hay ni la mitad de lo que era"), de añoranza por aquello que se tuvo y ya no es, es decir, se insinúa la idea de una nación que se ha ido escapando de las manos o de la que los han ido apartando unas élites egoístas. 


\section{La nación en la escuela que se valora}

En el presente acápite se agrupan las narrativas que ponen el acento en las experiencias de formación valoradas en términos positivos y cuyas huellas son consideradas determinantes para las opciones actuales de los jóvenes, según su propia versión. Aquí son evocadas por los jóvenes la invitación a reflexionar, a generar espacios de discusión, y la alusión a los ejemplos de cuestionamiento social sobre la realidad nacional. Esta escuela vivida que promovió un tipo de pensamiento reflexivo pone en evidencia el giro de finales del siglo pasado respecto a la función de la enseñanza del conocimiento social e histórico. Viraje explicado por Carretero y Kriger (2004) como la nada tranquila transición de un momento nacional a uno posnacional, en que la escuela "debe reposicionarse y encontrar nuevas funciones y sentidos, o de lo contrario correr el riesgo de perder sentido histórico y legitimidad" (p. 88). Estos relatos ilustran una escuela que no reverencia el proyecto nacionalista, que más bien hace parte de una corriente que brega por romper con los ideales románticos. El recurso que permitió este acercamiento fue la pregunta por un sentido legítimo de nación, mediado por las personas y las situaciones de la escuela vivida, que fueran destacables por marcar opciones y valoraciones presentes. Revisemos algunos fragmentos de relatos en esta línea:

Jennifer (1 ${ }^{\text {er }}$ semestre):

[Recuerdo] una profesora del colegio de donde yo salí, se llama Giselle M. Ella tiene este sentido que a mí tanto me gusta, ese sentido de querer luchar, de querer mostrarle a los jóvenes la historia, mostrarle su contexto, mostrarle los errores, mostrarle los aciertos respecto a los gobiernos y ese tipo de cosas, para que ellos se den cuenta a qué pertenecen y de qué forma pueden aportar a eso. Se me hace que es una colombiana que me gusta.

Jonathan $\left(7 .^{\circ}\right.$ semestre):

A mí sí me han marcado los profesores, de hecho, creo que por eso soy de los únicos que en la familia han tratado de estudiar por su parte. En bachillerato me marcó el profesor de Sociales porque era el de: "piensen, piensen mal o piensen bien, pero piensen", el tipo era atrás con el glosario: "ustedes manejan un lenguaje muy reducido, por eso ustedes no se saben expresar". Era muy cansón con esas cosas de leer historia, muy disciplinar. El profesor de Física era muy bueno porque inculcaba amor a la materia. El profesor de Sociales era muy radical, criticaba los procesos de democracia o el Día de la Raza, y uno se quedaba con eso. Yo quiero irme por 
ese lado, yo quiero saber qué está pasando, yo quiero saber qué significa que yo vote, qué significa un representante estudiantil, un personero.

\section{Rubén (7. ${ }^{\circ}$ semestre):}

Desde los profesores con los que estoy en información académica diariamente, hasta las personas o los procesos en los que de alguna manera he participado, desde el colegio, que tuve la oportunidad de participar en diversos procesos del consejo estudiantil, de todo lo que fue el 2007. Acá en la universidad tengo cercanía con personas de distintas organizaciones estudiantiles, con personas valiosas de las cuales he aprendido y se aprende mutuamente. Pero sí, en definitiva las personas marcan mucho en esa cuestión.

Estos testimonios dan cuenta de las personas que incidieron en su proceso formativo, sus prácticas, y de las razones por las cuales fueron influenciadas por ellos. Esta orientación crítica no es revisada por los jóvenes en lo fundamental, en función de establecer algunos contenidos específicos, sino que es rememorada con actitudes como la "invitación a pensar", a "querer luchar", a "criticar". Las personas y situaciones "valiosas", que "marcan" y que dejan "huella", también son invocadas desde las opciones presentes de los estudiantes, tal como dicen Jonathan: "yo quiero irme por ese lado", o Jennifer: "es una colombiana que me gusta". En este punto se puede observar la utilización de ciertas estrategias identitarias (Giménez, 2002), en las que, valiéndose de cierta capacidad plástica, la identidad aparece como medio para alcanzar un fin. Los jóvenes demuestran una identificación con aquello y aquellos que en su momento resaltaron lo que valoran hoy. "El concepto de estrategia indica también que los actores sociales disponen de cierto margen de maniobra, y que en función de su apreciación de la situación utilizan de una manera estratégica sus recursos identitarios" (Giménez, 2002, p. 47). Este recurso explica además las variaciones que pueden sufrir las identificaciones: ayer unas, hoy otras y probablemente mañana otras distintas, con otras personas que influyan y otros acontecimientos que ameritan lugar en la memoria.

Dada la complejidad del sujeto, las configuraciones subjetivas no son réplicas del pasado, también se pueden levantar como reacción a ellas. Algunos estudiantes expresan su intención de ser maestros diferentes a los que ellos tuvieron. Por ejemplo Doniben, hablando del desacuerdo con el estilo de sus docentes de colegio, aduce: "yo creo que como profesor trataría de hacer que eso fuera distinto". No solo emerge el carácter interesado de las memorias, sino la dimensión re-creativa y 
dinámica que tienen las experiencias escolares en tanto forjadoras de identidades personales y sociales.

Algunos jóvenes explican sus desapegos actuales también desde su formación escolar, lo expresa Laura de la siguiente forma:

Laura (7. ${ }^{\circ}$ semestre):

He sido como muy atípica con esas cosas [de la identidad nacionall, igual en el colegio como que no se nos inculcó esa identidad nacional, yo no viví los rituales de la izada de bandera, el Día de la Lengua, nosotros no vivimos ese tipo de actividades y creo que eso influye para que no tenga ni siquiera esa conciencia de las fechas patrias, sobre nuestros hombres heroicos, no tuve esa formación y creo que eso influyó; en la universidad pues creo que también tuve conciencia de esas distancias y eso hizo que esas distancias sean como más percibidas, se puedan mostrar, sean como más evidentes.

"Esa formación" y "ese tipo de actividades" que no experimentó Laura se refieren a las enseñanzas de corte romántico que insuflaban el vínculo con la nación propia y se cruzan de alguna manera con los profesores que recuerdan Rubén y Jonathan. Estos recuerdos no nacionalistas, reforzados por las dinámicas de la vida académica universitaria, no parecen dar cuenta del reemplazo de imaginarios de carácter disciplinar y cognitivo (Carretero, Rosa \& González, 2006). Es decir, ninguno de los estudiantes de este último grupo, bien desde unos recuerdos que se valoran positivamente, o bien desde una enseñanza indiferente al sesgo patriotero, ofrece una versión alternativa respecto a la nación. Se hace así patente la división que la reciente literatura ha construido entre historia enseñada, historia académica e historia cotidiana ${ }^{7}$, en el sentido de que la no presencia de una historia escolar de corte romántico no necesariamente implica la presencia de una historia académica o científica en el aula; más bien, como se detallará adelante, es ocupada por una suerte de voluntarismo político.

Hasta aquí se ha intentado profundizar en dos matices - nacionalista y problematizador - de las memorias escolares sobre identificación nacional, esbozados por los estudiantes participantes. A continuación se

7 "Si la historia escolar es la que vinculamos a los libros de texto y al currículum educativo, la cotidiana es el elemento de una memoria colectiva que se inscribe en la mente de los ciudadanos, y la académica (o historiografía) es la que cultivan los historiadores y los científicos sociales, de acuerdo con la lógica disciplinaria de un saber instituido bajo condiciones sociales e institucionales específicas" (Carretero, Rosa \& González, 2006, pp. 18-19). 
expone la clasificación de los relatos sobre la mirada que estos jóvenes hacen sobre la nación en la escuela que piensan para el futuro.

\section{La nación en la escuela que se proyecta}

Algunos testimonios de estudiantes, al momento de ser interpelados por la relación de la escuela y la identidad nacional, se remiten a un deber ser, a lo que según ellos se debería decir, hacer y enseñar en la escuela. De nuevo, la identificación nacional se convierte en una excusa temática para defender inclinaciones éticas y políticas respecto a una forma de educación y de escuela. Esta reivindicación de un tipo de enseñanza escolar revela un tinte moral al señalar una prescripción efectuada desde la militancia o simpatía organizativa de algunos de los estudiantes que participaron en las entrevistas, aspecto que fue detallado en el apartado de identificación con proyectos colectivos.

La construcción de la imagen de lo deseable pone en tensión el manejo del tiempo, que se refiere a la proyección de un futuro que es posible desde los significados que ofrecen las figuras del pasado y del presente. “Un aspecto esencial de la educación es el ser 'proyecto', y esto señala la importancia de un cierto imaginario individual y colectivo que lo configure y le dé fuerza de proyección futura" (Gimeno, 1999, p. 30). Como veremos, de acuerdo a las entrevistas desarrolladas, hablar del deber ser de la escuela y la sociedad es mencionar el futuro, el proyecto, el ideal de nación propia. En este énfasis aflora una insatisfacción con el presente y con el pasado, no para remarcar su desconocimiento, sino su modificación en procura de un orden deseado. La identificación nacional mencionada en este acápite pasa por el proyecto de escuela y de país soñado. En particular, en los relatos, sobresalen dos tendencias: la nación en la escuela para el compromiso social y la nación en la escuela para la conciencia planetaria. Veamos.

\section{La nación en la escuela para el compromiso social}

Los fragmentos de relatos aquí considerados develan un imaginario que propende por una identificación con la nación propia en función de una educación y una escuela generadora de conciencia social y compromiso comunitario. Desde la educación formal o desde la no formal, con acento en determinados contenidos o con la activación de nuevas perspectivas de pensamiento, estos jóvenes desean en la escuela un rol puntual hacia el futuro: generar compromiso con la sociedad de la 
que se hace parte. He aquí algunos testimonios significativos ante la pregunta por el futuro deseado:

Jennifer (1. ${ }^{\text {er }}$ semestre):

Como estudiante, pues todavía no tengo mucho que aportar porque hasta ahora me estoy preparando, pero las cosas que quiero hacer como maestra sí, quiero aportarle mucho al país, enseñarle la historia de este país en todas partes para que todos la conozcan y no solo mostrarlo del lado izquierda o derecha, sino que todos puedan distinguir entre ambos. El discernimiento lo hará cada cual [...] Espero en un par de años dar un aporte más fuerte.

Diana (1. ${ }^{\text {er }}$ semestre):

Lo que le digo, yo sí quiero ser maestra y quiero motivar a mis estudiantes a que también generen ese cambio y que eso trascienda, que no se quede como ahí, que yo vine a la universidad y aprendí esto y ya, y que me dicen las cosas, sino que también cuando yo sea maestra incentivar a mis estudiantes a que hagan lo mismo, que piensen más allá de lo que les dicen, que no se queden con lo que ven, con lo que les dicen los noticieros, sino que miren por qué es eso.

Gisell (1. ${ }^{\mathrm{er}}$ semestre):

Yo quiero ser profesora y ver niños desde pequeños que quieran salir adelante, y que no sean como tan ciegos, algo así, que no se crean todo lo que les dicen, que sean críticos.

Julián $\left(7 .^{\circ}\right.$ semestre):

[Yo enseñaría] un poco la historia del país, pero no de la manera tradicional, de generar amor a la patria, sino conocer por qué estamos así, qué problemas nos han hecho estar como estamos.

Jogser $\left(7 .^{\circ}\right.$ semestre):

Como futuro docente, me ubico como en hacerle ver al alumno desde cualquier estancia, ya sea desde la educación formal o desde la educación popular, mostrarle al estudiante lo que está bien y dejarle la capacidad de cuestionamiento y de preguntarse frente a lo que está haciendo: ¿qué está pasando? Yo como docente le puedo dar a ese alumno esa capacidad de decir: "ihey!, yo puedo influir de cierta manera en forma crucial en el cambio de mi realidad y, por qué no, de mis pares". Ese sería el papel que yo me vería desempeñando en esa capacidad de crítica y de cuestionamiento de mi propia realidad y de mi entorno y como puedo cambiar en ello de alguna forma. 
Testimonios como "quiero aportarle al país", "quiero motivar a mis estudiantes a que también generen ese cambio", "mostrarle al estudiante lo que está bien y dejarle la capacidad de cuestionamiento" informan de una importante tendencia a la orientación eminentemente política que se le quiere imprimir a la enseñanza de lo social en la escuela. Menos preocupados por transmitir sentimientos patrios, determinado tipo de saber, o de expresar una responsabilidad con el conocimiento, estos jóvenes estudiantes perciben la educación como un escenario de transformación social que puede darse en la escuela o fuera de ella.

Esta tendencia coincide con una importante tradición teórica preocupada por entender el sentido de las Ciencias Sociales escolares (Siede, 2010; Arias, 2005; Hernández, 2002; Cooper, 2002; Benejam \& Pagés, 1997; Finocchio, 1993), aunque es de anotar que en la literatura no ha habido total acuerdo respecto al propósito final de la enseñanza de las Ciencias Sociales. En todo caso, los contenidos y procedimientos propios de esta área del conocimiento se han adaptado a las necesidades de los contextos locales y a los requerimientos de los gobiernos de turno expresados en políticas públicas y lineamientos curriculares (Arias, 2009). No hay consenso entre las facultades formadoras de docentes al respecto y las carreras se debaten entre los contenidos disciplinares, la formación para el ejercicio de la ciudadanía democrática y la formación investigativa (Aguilera \& González, 2009). Por ejemplo, Siede (2010) considera que la enseñanza de las Ciencias Sociales puede generar condiciones para formar conciencia histórica, construir identidades múltiples y convergentes y aportar al ejercicio de una ciudadanía democrática, mientras que para Pagés (1997) tiene que ver con la adquisición de los conceptos, procedimientos y actitudes para comprender la realidad humana y social del mundo que vive el estudiante. La mayoría de los perfiles deseados sobre la enseñanza de las Ciencias Sociales y la historia coinciden en postular una formación para el ejercicio de la ciudadanía democrática y deliberativa. "Los saberes sociales, históricos y geográficos son tanto o más útiles y funcionales que cualquier otro, en tanto inciden en la formación de una ciudadanía con criterio, el activo más importante al que debe aspirar cualquier comunidad" (Hernández, 2002, p. 8). Esta perspectiva que incita a la intervención activa en las dinámicas sociales se hace carne en la voz de Jogser: "yo puedo influir de cierta manera en forma crucial en el cambio de mi realidad", o en Diana, que desea impactar en sus estudiantes para que "generen ese cambio y que eso trascienda". La pregunta por el lugar de la identidad nacional en la escuela es revestida por estos jóvenes como la posibilidad de provocar cuestionamiento hacia la realidad social e inculcar vinculaciones a proyectos políticos en sus futuros estudiantes. 
Estos jóvenes son conscientes de los profundos tejidos tendidos entre la escuela y la sociedad, por ello otro hallazgo importante son sus deseos de intervención, que no se restringen al espacio formal de la escuela y se proyectan con aportes en ámbitos sociales más amplios. La identidad nacional se solapa de cambio social y el sueño se vive como deseo de transformación y como apuesta personal para que ello sea posible. Veamos.

Karen (1. ${ }^{\text {er }}$ semestre):

Me gustaría ser educadora popular, en una comunidad, en ese sentido quiero aportarle. Para eso estoy haciendo una licenciatura para ser una profe, pero no una profe normal, educación popular, con la pedagogía de Freire [...] Aprender entre ambos para saber la situación en la que está la persona a la que le estoy enseñando y caminarle a lo que se esté enseñando, a las necesidades.

Manuel (7. ${ }^{\circ}$ semestre):

Entonces yo dije: "voy a ser profesor" y pues ahí voy. No se me ha quitado la idea tampoco y precisamente por esa idea de vincularme más con esos procesos sociales, porque desde la labor docente se puede hacer rebien. Vincularse con lo social desde la labor docente es más fácil. Uno tiene acceso a la comunidad por lo menos, aunque cada vez sea más fragmentado todo. Uno tiene acceso a la comunidad todavía y si uno tiene acceso a la comunidad todavía, y aunque el maestro ya no tenga esa posición de antes, esa figura que había... la labor docente es importante por ese vínculo con la comunidad. Entonces desde ya, incluso desde estar haciendo sus cositas y sus proyectos y sus prácticas se vincula uno con proyectos en todo lado, trabajando por allí, trabajando por allá.

Rubén (7. ${ }^{\circ}$ semestre):

Digamos que el educador no se puede conformar con ser un intelectual de enciclopedia, sino que efectivamente tiene que hacer su labor crítica, educativa y formativa desde las aulas, pero también tiene que salir a muchas dinámicas que exceden el campo pedagógico y el campo educativo. Entonces, digamos que como base, siendo educador, pero desarrollando también proyectos sociales y políticos que me parecen importantes, sin querer decir que la educación no sea un aspecto político, que la educación no sea una herramienta, porque evidentemente lo creo, pero creo que desde la educación se puede hacer todo, la educación es herramienta y es un sector importante que hay que desarrollar. 
La descripción hecha de la escuela para el compromiso social engancha perfectamente con las motivaciones sociales y políticas de los estudiantes que participaron en esta presente investigación, pues la conciencia de ser jóvenes críticos que desean la transformación social se une a su proyección profesional como educadores de las nuevas generaciones de las que se consideran, en parte, responsables. El vínculo y el acceso a la comunidad rebasan la educación formal y ponen de manifiesto que lo clave es el deseo de aporte político a la sociedad, independientemente del escenario en el que dicha contribución se pueda realizar, como dice Manuel: "trabajando por aquí, trabajando por allá". Asimismo, esta aspiración plantea una conexión con las lealtades sociopolíticas de los jóvenes presentadas en el capítulo anterior, en el apartado de la identificación con los proyectos colectivos. Allí se hacía alusión a las adscripciones realizadas, a nombre de la vinculación con la nación propia, a propuestas políticas de horizonte transformador.

Sin embargo, puede leerse un exceso de voluntarismo político en estos relatos que conlleva una sobrevaloración a las posibilidades de la educación en la transformación social ("desde la educación se puede hacer todo"). Igualmente, se observa la forma como se solapan opciones ideológicas y compromiso profesional. Este énfasis en el cambio insinúa una especie de mesianismo político que implica la posesión de la visión correcta y la fórmula salvadora: "yo quiero ayudar a mi país, pero más que al país, es a la humanidad [...] por eso estudio Sociales y no otra cosa. Porque para mí lo social es importante, y eso me motiva, incentivar un cambio en el país", refiere Brayan. En Gisell esta voluntad es evidente al desear rectificar lo que anda torcido: "o sea, para mi sí se pueden cambiar las cosas [...] todo produce un cambio, así sea pequeño, entonces si uno le dice a un niño, uno puede ir enderezando ese camino así sea de a muy poquito"; en Edwin, quien afirma: "yo creo y estoy acá no para transformar a nadie, sino para transformarme a mí mismo y a partir de mi transformación quizás generar cambios en los demás"; en Julián: "pues yo espero afrontar desde el campo que escogí, la profesión docente, como un cambio social, que la gente se dé cuenta de que esto está vuelto nada, y que haga algo, lo que sea que haga, pero que haga algo, entonces me veo tratando de ayudar a que esto no sea tan malo".

Isabelino Siede (2010) dramatiza esta situación en la figura del docente Sandokán, atento a la lucha que, sin embargo, ve la realidad desde la lógica binaria de amigos-enemigos y que ante el eventual fracaso de su gesta puede amargarse y victimizarse. Este docente, agrega el autor, "es coherente y comprometido, aunque rara vez sale ileso de su epopeya: 
se agota y se desgarra, cayendo en las trampas generadas por la lucha con más coraje que cabeza" (p. 242). Este coraje se observa no solo en las palabras de algunos de los jóvenes participantes, que proyectan su posible futuro como docentes; también, cual se apuntó, en sus actuales militancias sociales y políticas en organizaciones barriales o estudiantiles.

Como se observa, los imaginarios sociales de los estudiantes respecto a la identidad nacional pasan inevitablemente por la proyección de futuros deseables para la escuela y para la sociedad. Dichos imaginarios expresan una importante carga política, pues el perfil de la nación soñada imbrica el cambio escolar y social en una dinámica cargada de justicia y democracia, que abre la historia a un mundo de posibilidades en el que los jóvenes se sienten protagonistas y gestores.

Otro grupo de jóvenes traslució una idea de fidelidad a la nación propia, ya no en términos de compromisos sociopolíticos, sino de fraternidad y cuidado del mundo, aspecto que se profundizará en el apartado que sigue.

\section{La nación en la escuela para la conciencia planetaria}

La idea de una conciencia cosmopolita que no admite otras fronteras que el mundo mismo y que propende por la solidaridad con la raza humana viene haciendo curso en la escuela y es defendida por algunos de los estudiantes universitarios que participaron en la investigación. Lejos de las trampas que imponen las lealtades nacionales se considera que incentivar sentimientos hacia lo patrio es peligroso o estéril, más bien rescatan el vínculo con la humanidad y con la naturaleza. Veamos.

Edwin (7. ${ }^{\circ}$ semestre):

Lo latinoamericano hay que romperlo, para ser habitantes del mundo. Es no negarnos también esa condición, sino complementarla con esa visión de que Latinoamérica no termina en la Patagonia, ni empieza en el río Bravo, sino que también pertenecemos a ese mundo, a ese mundo que nos convoca [...] Como humanos nos pertenece el mundo. Como también le pertenece el mundo a las distintas especies que la habitan. En ese sentido digo que no nos pertenece algo para explotarlo, para usarlo, sino porque estamos ahí y del entorno que nos rodea depende nuestra existencia [...] En ese sentido, esa nacionalidad, o sea soberanía nacional, se rompe para más bien defender lo que humanamente nos pertenece, humanamente nos contiene. 
Esteban (7. ${ }^{\circ}$ semestre):

Desde mi punto de vista, identificarse con el territorio significa la responsabilidad que cada individuo tiene de permitir y garantizar el mantenimiento del entorno en el que habita, ya que todos hacemos parte de un gran tejido universal, en una condición de complemento y reciprocidad, de esta forma el planeta es un organismo vivo del cual hacemos parte porque nos alimentamos de él, pero con el cual no somos justos a la hora de preservar su vida, ya que están por encima nuestros deseos individuales y colectivos como humanos.

Lizeth (7. ${ }^{\circ}$ semestre):

Por tanta violencia en este paí, hemos olvidado nuestra concepción de humanidad [...] Algo que sí nos falta como colombianos es rescatar el valor de la afectividad, de los talentos, del ser humano, de una comunicación más cotidiana, de no tratar de estereotiparnos y seguir discursos ajenos que significan más que la construcción de un yo, un yo colectivo también, sino de un otros, de un ellos, un ellas, sino más bien construirnos nosotros, como comunidad, como una comunidad humana, una comunidad planetaria que puede cada vez ser mejor, que pueda construirse y ser cada vez más perfecta.

Esta invocación de una conciencia cosmopolita, aunque minoritaria en las respuestas de los estudiantes participantes en este estudio y expuesta únicamente por los chicos de séptimo semestre, se complementa con el apartado anterior, la nación en la escuela para el compromiso social, pues se encuentra en sintonía con los cambios educativos contemporáneos, con las políticas para la enseñanza de las ciencias sociales y la historia, que a finales del siglo pasado empezó a mirar con reticencia la educación patriotera. La revisión de las experiencias educativas de las dictaduras (Kaufmann, 2006), las aperturas democráticas, la caída del Muro de Berlín, la creciente profesionalización docente y el impacto de la globalización en la educación y la escuela (Mejía, 2006) han contribuido enormemente a fracturar la vieja relación entre nación y escuela, o por lo menos la ha vuelto 'políticamente incorrecta'. En el caso de los jóvenes indagados, esta conciencia planetaria puede provenir, lo mismo que la conciencia frente a los discursos nacionales, de las herramientas que adquieren en su formación universitaria y del desdén que experimentan hacia la realidad de su nación: "Por tanta violencia en este país hemos olvidado nuestra concepción de humanidad", admite Lizeth. 
Esta tendencia también se emparenta con lo encontrado en el capítulo anterior, concretamente con la identificación nacional, que algunos estudiantes evidenciaron, referida al territorio y la naturaleza. Allí se mencionó cómo la simpatía por la nación propia pasaba antes que nada por la admiración a los paisajes y la vida silvestre. En esta misma dirección, algunos estudiantes consideran que la labor de la escuela debe estar encaminada a este tipo de identificación con lo propio, que ahora se amplía a los confines del planeta.

Esta percepción marcada con elementos cosmopolitas sobre la identidad y el papel de la escuela que algunos jóvenes traducen en su discurso probablemente recibe el influjo de su formación académica (licenciatura en Ciencias Sociales en universidad pública), de los medios de comunicación, de la información sobre el turismo global y del contacto con la Internet. En todo caso, esta tendencia no coincide con otros hallazgos de pesquisas realizadas con una población parecida y también para Colombia. Hoyos, del Barrio y Corral (2004) encontraron las siguientes cuatro características que definen la identidad nacional en jóvenes y niños de dos contextos diferentes a partir de sus representaciones: 1) que la nacionalidad se atribuye como una condición fija dada fundamentalmente por el nacimiento; 2) cuando es posible el cambio de nacionalidad y la justificación no es legal, se acude a elementos anecdóticos; 3) cuando hay cambio de nacionalidad con justificaciones legales aparecen argumentos en los que este proceso solo es posible para algunas personas y gracias a la adopción de aspectos culturales; y 4) cuando hay cambio de nacionalidad también con justificaciones, pero con argumentos que se refieren a elementos institucionales y políticos. En este estudio, la condición nacional no se cuestiona ni es imputada por los jóvenes y los niños participantes, más bien se naturaliza y, según los autores, a medida que se avanza en la edad "se registra un progreso en cuanto a la comprensión del concepto de nacionalidad" (p. 98). Este resultado está en consonancia con el método clínico adoptado en dicho estudio y por la pregunta problema: la influencia de la situación político-económica en la manera en que se concibe y se valora el hecho de ser colombiano. La población objeto fueron estudiantes de educación básica de colegios privados, personas que, a diferencia de los jóvenes del presente caso, difícilmente han desarrollado la capacidad y las herramientas necesarias para cuestionar los conocimientos y comportamientos adquiridos respecto a la identidad nacional, idea que fue evidente no solo en referencia a la distancia que algunos establecieron respecto a la escuela nacionalista, sino a las distintas tendencias caracterizadas en el capítulo anterior. 
En el caso de los estudiantes que participaron en el presente trabajo (estudiantes universitarios), la disposición de la escuela que se ha Ilamado planetaria en detrimento de una educación de corte nacionalista, puede explicarse por la cercanía con el mundo académico, que privilegia contenidos teóricos y saberes especializados, así como por el ambiente crítico y militante propio de una universidad pública, lo que promueve la aparición de discursos contrahegemónicos en los estudiantes, muchas veces sin mayor desarrollo o fundamentación. Según Carretero (2007), tal transformación tiene que ver con una modificación más gruesa: la de la historiografía misma, que fue permeable a la fracturación de las identidades sucedida después de la Segunda Guerra Mundial, a la irrupción de nuevos grupos de diversa índole en el escenario social y a la importancia que toman los estudios sobre nuevos actores hasta entonces invisibilizados.

Queda pendiente por indagar la forma como este imaginario relacionado con el deber ser de la identidad nacional y la enseñanza de las Ciencias Sociales cercano a valoraciones cosmopolitas se mantiene o se modifica en el ejercicio de la práctica docente en los sujetos que participaron en el estudio. La futura realidad escolar de estos jóvenes que hoy impugnan la formación para la identidad nacional patriotera a favor de una adscripción más universal puede variar en el tiempo, y por qué no, recrear estas pretensiones hechas a la distancia de su ejercicio docente.

Por otro lado, vale la pena mencionar que en el grupo focal de primer semestre se presentó la siguiente situación: la mayoría de los estudiantes de este nivel, en las entrevistas en profundidad, había expresado su propensión a generar cierta conciencia nacional en su futura labor docente; sin embargo, uno de ellos, Brayan, disentía al afirmar la necesidad de abrir las perspectivas de los niños a la humanidad y al planeta y no hacia una nación cuyos emblemas y símbolos eran utilizados por una élite interesada. Esta disensión fue llevada al grupo de discusión. Veamos dos intervenciones al respecto:

Entrevistador: ¿Qué opinan de la mirada de Brayan, que no coincide con la de ustedes?

Juan (1. ${ }^{\text {er }}$ semestre):

La concepción de Brayan, para un niño, para el futuro, es la mejor. Ahorita sí amor a la patria, pero para educar niños ya es otra cosa, una cosa mucho más grande que los pensamientos que uno pueda tener. Hay que inculcar un amor por todo. Pero si vamos 
a hacer un cambio de verdad, sí, la de Brayan, porque igual, en algún momento, las fronteras se van a ir y todos vamos a ser un número o algo así.

Jennifer (1. ${ }^{\text {er }}$ semestre):

Entre mis recuerdos está lo que contesté la otra vez, yo decía que era importante enseñar eso [de la identidad nacional] en la escuela porque conocer la historia nos iba a ayudar a no repetirla, y conocer quiénes somos nos puede ayudar a tratar de ser mejores, pero viéndolo desde otras formas, viéndolo desde que esa identidad también puede generar odios y cosas, digo, pues sí, no les enseñemos cosas para que odien al de afuera. Estaría de acuerdo con las cosas que plantea Brayan, enseñarles cosas para que quieran su patria pero que también quieran la demás gente, y que serían humanidad precisamente porque si nos quedamos así viéndonos como solo Colombia [...] Es importante vernos como Colombia para saber quiénes somos y qué porquerías hicimos en el pasado, pero también es bueno ver la humanidad. Yo enseñaría ambas porque ambas son importantes, pero recalcando que es mucho más importante el amor hacia la humanidad que el amor hacia la gente que está en esas fronteritas, porque puede que el que se sale de aquí de la frontera sea igual que nosotros. No puedo enseñar a que solo esas fronteras y el respeto a eso, sino a todo el mundo.

La lectura y la valoración de las experiencias nacionalistas llevan a estos jóvenes estudiantes a plantear una situación ambigua. Juan afirma que la enseñanza sobre el amor a la patria quizá vale la pena para los jóvenes y los mayores ("ahora sí amor a la patria"), pero no para los niños, en tanto condición de futuro ("hay que inculcar amor por todo"), además lo hace no porque tales sentimientos sean peligrosos, sino porque imagina que en el futuro no habrá fronteras o no se requerirán. Por su parte, curiosamente Jennifer afirma que todavía hay que enseñarles a los estudiantes "cosas para que quieran su patria", pero en el futuro, con los niños, es diferente, aunque dice que son importantes las dos: amor a la patria y a la humanidad, y cierra inclinándose por la segunda. Parece que reflexiona mientras va construyendo su discurso, no tiene una posición fija. Analizando estas narrativas, en el fondo, las enseñanzas que promueven sentimientos de adhesión a lo nacional se resisten a ser cambiados, no quieren dejar la escuela y titilan en los imaginarios de adscripción identitaria de estos maestros en formación. Cuando son cuestionadas las posiciones tradicionales se producen respuestas ambiguas, se busca conciliar lo nuevo y lo viejo, se requieren malabares argumentativos para justificarse. Tantos años de presencia del discurso nacionalista en el currículo y en el discurso público no han sido en vano. 


\section{Conclusiones}

La adscripción a la nación propia se expresó en el presente estudio como la exaltación de la belleza del paisaje y las riquezas naturales. Lo regional estuvo matizado por el rescate de las tradiciones y de prácticas legendarias. Las menciones sobre el territorio se hicieron no tanto como espacio físico de interés, sino en función del sentido cultural que soportaban y por las relaciones sociales que evocaban. En esta perspectiva se colige que, desde el horizonte de la identificación nacional, lo territorial tiene significancia sobre todo por lo que representa, por la importancia y la fuerza de las memorias que activa en las personas. Desde el siglo XIX la exaltación del territorio ha sido una corolario del sentimiento nacionalista en tanto sustento material del Estado nación; sin embargo, su invocación actual, menos amenazada por disputas limítrofes y afrentas a la soberanía, tiene que ver menos con la instancia física y más con el espíritu de las gentes que alberga.

Para los jóvenes universitarios esta mención de lo regional, mientras dio nombre propio a la identificación nacional, marcó de alguna manera una distancia política con el territorio, al folclorizar sus prácticas y esencializar su condición. Los relatos, en este punto, transmitieron una noción de cultura dependiente de las costumbres pasadas, puras e idealizadas, pertinentes de conservar y guardar. Esta identificación con lo local, para ciertos teóricos demasiado corta para procurar sentimientos nacionales de identificación (Smith, 1997), se vincula eficazmente con las estrategias de etiquetamiento hechas desde el poder (Appiah, 2007; Bolívar, 2006), es decir, si bien es claro que los mecanismos de identificación nacional requieren de membresías previas a las cuales adherirse, a las cuales suscribirse la mayoría de los ciudadanos, tal nominación, en el caso de los jóvenes de esta investigación, tuvo en lo local y en lo regional una expresión profunda de filiación, aspecto que probablemente se corresponde con las maneras como históricamente lo regional ha sido un componente central en la configuración de lo nacional en Colombia (González, 2001). En los jóvenes escasean las alusiones al territorio nacional como un todo. Además, hay que entender que lo regional ha funcionado en el pasado como un mecanismo activo de jerarquización social (Herrera, Pinilla \& Suaza, 2003), y aunque estos estudiantes no legitiman la discriminación a las diferencias culturales, biológicas o climáticas, en sus discursos se notan las se- 
cuelas de haber mantenido por años una nación separada, dividida y hasta aislada en sus territorios regionales. La nación o el sentido de lo nacional, en suma, se subordina a lo regional o se reduce a ello.

Un corolario de la identificación con el territorio regional, en tanto espacio próximo de filiación, lo constituyó la identificación con grupos cercanos, básicamente la familia, los pares y los amigos. La identificación nacional se revistió, en este caso, del nombre de personas conocidas y concretas. Para algunos autores (Uribe, 2001) esta modalidad de pertenencia que no trasciende lo inmediato se emparenta con la historia de la cultura política en Colombia, circunscrita a identidades colectivas simples debido a la fuerte polarización y fragmentación de la sociedad. De acuerdo a los relatos de los jóvenes universitarios el vínculo con el territorio local y con los grupos que son familiares parece que retribuye el déficit del nosotros nacional que el Estado les adeuda, otorgando con relativa eficacia pequeñas fidelidades hacia las personas y los espacios de interacción cotidiana.

Pertenencias ceñidas a lo inmediato, invocadas a nombre de la identificación con la nación propia, remiten a la dificultad para desplegar una comprensión política de lo nacional, y también a una dinámica propia de las subjetividades contemporáneas (Arias, 2012) centrada exclusivamente en lo íntimo (Sennet, 1978) y provocada por la ausencia de Estado (Lewkowicz, 2004) o por el reclamo de una presencia legítima de él. La admiración a la nación, experimentada en el territorio cercano, en los espacios locales, en los encuentros familiares y amigables, de alguna manera suple la distancia con un Estado que parece esquivo e insuficiente para satisfacer las demandas materiales y simbólicas que hacen las nuevas generaciones. La canalización de los afectos hacia lo nacional en esta dirección, impulsada por el mismo Estado, es funcional a su repliegue y a la despolitización de lo cultural, pues lo identitario es despojado de su carga conflictual e histórica bajo una consideración esencialista que suscita emociones hacia cosas, ambientes o personas que poco o nada interpelan el orden social vigente.

Estas filiaciones domésticas se corresponden, en parte, con la tendencia al individualismo contemporáneo que claudica a los proyectos comunitarios y que promueve soluciones biográficas a contradicciones sistémicas (Bauman, 2001) que el mismo sistema ha provocado. Así, muchos jóvenes insisten en entender y expresar la nación como algo que está encarnado en las personas mismas, en sus formas de vida, en su esfuerzo cotidiano y en los afectos que estas relaciones suscitan. 
En un sentido radicalmente distinto al anterior, algunos jóvenes dijeron experimentar la adscripción con la nación propia como identificación con los proyectos colectivos, esto es, como vínculo con propuestas de cambio social en curso en el ámbito de apuestas por militancias políticas y como rechazo hacia la violencia que sufre Colombia. En esta tendencia fue manifiesto el compromiso personal de los jóvenes, en algunos momentos rozando en la idealización de los sectores marginados de la población. La simpatía con proyectos colectivos de cariz político, probablemente motivada por su pertenencia a organizaciones sociales, visibiliza el rechazo de algunos jóvenes universitarios a los discursos hegemónicos que impulsan adscripciones no conflictivas con el orden establecido. Estos relatos sobre la identificación nacional hicieron explícito el componente político de la identidad, en tanto campo de tensiones y luchas sociales por el reconocimiento (Appiah, 2007; Sen, 2008).

La identificación con los proyectos colectivos reveló con fuerza la dimensión política del vínculo con la nación propia, en la medida en que se hicieron públicas las adscripciones ético-políticas de los jóvenes participantes y fueron explícitas sus articulaciones a los órdenes sociales deseados (Lechner, 2002). La noción de nación no fue impugnada, más bien fue nominada a partir de un proyecto alternativo del que los universitarios participantes parecían sentirse actores de primer orden. Si "la política es la lucha que busca ordenar los límites que estructuran la vida social, es el proceso de delimitación en que los hombres, regulando sus divisiones, se constituyen como sujetos" (Lechner, 1984, p. 15), entonces, el deseo se hizo palabra en la voz de estos jóvenes que tomaron partido en la disputa por la organización del orden social.

En las alusiones a la cultura que nos une se asumió que Colombia es un crisol de riqueza cultural y diversidad que debe ser cuidada y difundida. Lo rural y lo campesino tuvieron preeminencia. La nación se expuso como una sumatoria de partes que deben mantenerse originales. La cultura apareció en estos relatos como el encuentro de lo diverso, de la diferencia. La belleza del paisaje o la riqueza de las costumbres no solo fueron destacadas en función de variedad, expresividad y multiplicidad, fueron el sello distintivo de lo nuestro. Este imaginario de nación está a tono con la orientación mostrada en la identificación con el territorio regional, pues la importancia del paisaje natural y de las prácticas culturales tradicionales se enarbolaron como símbolo identitario y a la vez como definición misma de la nación. 
Estos elementos sintetizan una visión sobre lo cultural que desconoce la dinámica sociopolítica que le acompaña, ya que la idealización edulcorada de la coexistencia de la diversidad, lo mismo que el anhelo de armonía con la naturaleza, que le dan contenido a la nación propia y a la identificación con ella, pueden ocultar la cara conflictiva e interesada de unos discursos que según estos jóvenes buscan impulsar la imagen de una nación tranquila, rica, inclusiva y diversa.

Esta idea de nación, apalancada por los medios de comunicación (García, 1995), funge exitosamente como mito fundacional de la nación (Urrego, 1998), dando sentido a lo que supuestamente es propio y suplantando el vínculo que no provocan las instituciones del Estado. Esta pasión que despierta el exotismo por lo ancestral, lo rural y lo múltiple probablemente compensa en muchos jóvenes universitarios la profunda ausencia de un Estado que legendariamente ha demostrado su incapacidad para solucionar los problemas sociales básicos y generar sentimientos de pertenencia con base en la presencia decidida y tangible de su institucionalidad.

Para Omar Rincón (2001), a falta de un gran relato fundacional los colombianos buscan pequeños y frágiles mitos que les permitan imaginar una narración de la nación. Para este autor el mito territorial, que reconoce que somos una nación de diversidad cultural, permitiría establecer mecanismos de encuentro y diálogo, pero hoy se usa para excluir y desconocer. "La única forma de aprender de nuestra nación y sus gentes es a través de las masacres, que [...] han sido la forma más efectiva para aprender de geografía en Colombia" (Rincón, 2001, p. 16).

En esta sacralización de lo diverso, lo arcano y lo natural, no se hace evidente la presencia de un nosotros como actor colectivo (Lechner, 2002), esencia de la política, que permitiría la comprensión analítica de la realidad y su posible transformación. En suma, estas posiciones pueden contribuir a un conformismo político con la realidad imperante al confinar la cultura al ámbito de las esencias y al dificultar la lectura, en clave de poder, sobre el presente y el futuro de la nación.

Otro imaginario sobre los estereotipos de nación consiste en Colombia es pasión; aquí algunos jóvenes mencionaron el carácter aguerrido y extrovertido del colombiano, destacaron especialmente el deporte y la capacidad de superación de los pobres, cuya condición para sobreponerse, se supone, es ilimitada. El colombiano, dotado desde su nacimiento de un gen especial y de la capacidad para reponerse a cualquier 
desgracia, aparece dotado para sobrevivir en cualquier contexto por su humildad, tenacidad y esfuerzo.

Este imaginario social refuerza la idea de una nación excepcional y destinada a grandes cosas, pese a sus desgracias temporales (corrupción política, dependencia económica, desastres naturales). La magnanimidad de la nación reposa en la riqueza de sus expresiones, en el talante de sus gentes y en el exotismo de su cultura. Estos estereotipos han funcionado como régimenes de colombianidad, al decir de Castro-Gómez y Restrepo (2008), en tanto dispositivos que pretenden unificar y normalizar a la población bajo ciertas etiquetas de reconocimiento común. Aquí "lo nacional se constituye como un campo de poder desde el que son definidas, normalizadas y contestadas distintas entidades-identidades" (p. 11). Algunos jóvenes universitarios, de acuerdo a sus relatos — visuales y testimoniales—recrearon, sin mayor desacato, con distintos matices y fortaleza, el discurso oficial sobre los sentimientos de orgullo que provocan la pertenencia a una gran nación que sobresale por su espíritu tozudo, vibrante, explosivo y jovial.

Esta representación de una nación boyante, vigorosa, quizá promisoria, de nuevo es coartada en su dimensión política, o mejor, lo político aparece acá al servicio de eludir la discusión sobre la estructura social y el orden político vigente. Los sentimientos de admiración hacia las pretendidas virtudes esenciales del colombiano y hacia algunas prácticas tradicionales, que cotidianamente promociona el poder, contribuyen a naturalizar una idea de nación que aparentemente nada tiene que ver con las actuales disputas que se dan por imponer significados legítimos respecto a lo que es, ha sido y puede llegar a ser la nación.

En un sentido muy diferente a las anteriores tendencias, menos exitoso y triunfalista, un grupo de jóvenes universitarios consideró que lo característico de la nación consistía en las carencias e infamias que nos marcan. La injusticia, la pobreza, la corrupción y, especialmente la violencia, fueron la marca de la identidad nacional. En sus relatos afloró la decepción, el desgano y la frustración con la nación propia. Los déficits coparon el nosotros nacional. Para Rincón (2001) otro mito social vigente consiste en afirmar que la violencia ha terminado por ser el determinante de la estructura del carácter del colombiano, su marca de identidad, el cuento que permite unificar a la sociedad colombiana.

En algunos relatos de los jóvenes universitarios la violencia resaltó como sello de la colombianidad, ello se entiende porque han tenido como telón de fondo este fenómeno en su proceso de socialización; a 
la vez, en sus discursos se diluyó la posibilidad de leer estos déficits en clave de protagonismo político, pues sus críticas sonaron a señalamientos desesperanzados que redundaban en pasividad y conformismo. Este hallazgo constituye una novedad en la literatura consultada sobre la manera como los jóvenes de las generaciones contemporáneas experimentan su nación. Aquí la desilusión remite de nuevo a un descrédito frente a la ausencia de Estado que estos jóvenes experimentan, pero ese vacío no es llenado con hipertrofia de nación en lo cultural, ni con la idealización de la idiosincrasia y el temperamento de sus gentes, sino que se vive como un repliegue, como desazón y como una claudicación. El sentimiento de desapego hacia la nación propia, tan útil políticamente como las anteriores acepciones para desarmar voluntades, disminuye en este punto las posibilidades de participación, entendimiento y cambio del sistema social imperante. Este hallazgo no encontró posibilidades de confrontación con otros trabajos empíricos y constituye un aporte nuevo a los estudios sobre la identificación con la nación propia en jóvenes escolarizados.

Por último, es posible concluir que si bien las ideologías oficiales "no nos dicen lo que hay en el cerebro de sus ciudadanos o partidarios" (Hobsbawm, 1991, p. 19) tampoco es posible prescindir de tales lógicas para entender lo que imaginan los ciudadanos nacionales. La presencia del discurso oficial sobre la identificación con la nación propia fue clara y explícita en buena parte de los relatos que se vinculaban con el territorio regional, también en los estereotipos que destacaban la cultura que nos une y por supuesto en Colombia es pasión. Aquí se hizo visible al Estado como administrador de la identidad (Chihu, 2002), vía medios de comunicación y campañas cívicas, pues en uno y otro caso lo exótico, lo folclórico y lo tradicional por un lado, esto es, la apelación a la cultura y lo fuerte y alegre por el otro, es decir, la referencia a la capacidad de la gente, operaron como marcas que relacionaban la nación propia con los sentimientos de identificación hacia ella. También se hizo evidente en la identificación con los grupos cercanos, al provocar una respuesta privada e íntima ante una demanda política y pública como lo constituye la pregunta por la filiación nacional.

El discurso estatal sobre la identidad nacional, impulsado por los medios de comunicación masivos, la política profesional, el comercio y la escuela, con diferentes grados de aceptación y de conciencia, demostró probada eficacia en todos los casos y testimonios expuestos, en el sentido de que ningún imaginario, en el presente estudio, concibió los posicionamientos personales o colectivos por fuera de la nación. La adscripción a la nación tuvo diversos matices y definiciones, pero casi 
nunca se optó por un posicionamiento exento de ella. Incluso los más contestatarios esgrimieron su programa en las ideas de nación cuya naturaleza y condición se pretendían distintos, es decir, aquellos jóvenes estudiantes que esbozaron vinculaciones con la nación propia desde un horizonte de cambio y transformación sociopolítica se mantuvieron circunscritos a la idea de nación como algo importante e imprescindible. Solo dos estudiantes de los participantes en el presente estudio, uno de séptimo semestre y otro de primero, en la entrevista manifestaron sentirse abiertamente ajenos a la idea de identidad nacional porque pensaban que la nación colombiana o cualquier otra era finalmente un artificio, quizás innecesario para los tiempos que corren. Valdría la pena que posteriores estudios pudieran profundizar en las experiencias, razones y justificaciones que esgrimen este tipo de estudiantes y en el significado de sus apelaciones a un sentido cosmopolita de la enseñanza de la Historia.

Este carácter identitario que se piensa inevitablemente en el escenario de las naciones también se reforzó poderosamente en el hecho de que la mayoría de fotografías, o mejor, de los relatos visuales, se vieron afectados e intervenidos de una u otra manera por los colores de la bandera o algún ícono referido a la colombianidad, rostros humanos singulares cuyo marco de referencia (Taylor, 1989), horizonte de sentido y límite de reconocimiento se hizo dentro de los contornos de lo que aún representa para muchos el concepto nación.

Para terminar, Hobsbawm (1991) afirma que la identificación nacional puede mutar con el tiempo, puede desplazarse incluso en períodos bastante breves. Esto se encuentra en sintonía con lo que plantea Norbert Elias (1987), para quien la identidad social se modifica de acuerdo a las condiciones de integración de la sociedad. Estos planteamientos sirven para enfatizar la contingencia de los presentes hallazgos, la fragilidad de los vínculos humanos y la necesidad de profundizar con diferentes estrategias en las maneras como los sujetos nos configuramos y nos identificamos con la nación propia, en el caso de que tal entidad mantenga algún tipo de vigencia en el futuro. 

Alarcón, L., \& Conde, J. (2003). Manuales escolares, ciudadanía e identidad nacional en el Caribe colombiano. Análisis heurístico, bibliográfico y estudio histórico, educativo y pedagógico, 1832-1898, recuperado de http:// hum.unne.edu.ar/investigacion/educa/alfa/UniversidaddelAtl\%E1 ntico. pdf

Alridge, D. (2006). The Limits of Master Narratives in History Textbooks: An Analysis of Representations of Martin Luther King, Jr. Teachers College Record, vol. 108, 4, 662-686.

Altamirano, C. (2002). Términos críticos de sociología de la cultura. Buenos Aires: Paidós.

Álvarez, A. (2007). Ciencias sociales, escuela y nación: Colombia 1930-1960. Madrid, Universidad Nacional de Educación a Distancia: Tesis de doctorado.

Anderson, B. (1993). Comunidades imaginadas: reflexiones sobre el origen y la difusión del nacionalismo. Buenos Aires: Fondo de Cultura Económica.

Appiah, A. (2007). La ética de la identidad. Buenos Aires: Katz.

Apple, M. (2002). Educar "como Dios manda". Barcelona: Paidós.

Arfuch, L. (2002). El espacio biográfico. Dilemas de la subjetividad contemporánea. Buenos Aires: Fondo de Cultura Económica.

Arias, D. (2005). Enseñanza y aprendizaje de las ciencias sociales. Una propuesta didáctica. Bogotá: Cooperativa Editorial Magisterio.

—_. (2009). El cambio en educación: falacias, posibilidades y apuestas. En A. Osorio, \& D. Arias, Equidad y políticas públicas en educación. Análisis e incidencias (pp. 111-138). Bogotá: Fe y Alegría, Empresarios por la Educación.

Arias, D., \& Ruiz, A. (2013). Jóvenes, política e identidad nacional. Un estudio con jóvenes universitarios colombianos. Revista Argentina de Estudios de Juventud, 7, 1-22.

Arias, J. (2005). Nación y diferencia en el siglo XIX colombiano. Orden nacional, racialismo y taxonomías poblacionales. Bogotá: Universidad de los Andes. 
Balibar, É. (2005). Violencias, identidades, civilidad. Para una cultura política global. Barcelona: Gedisa.

Bauman, Z. (2001). La sociedad individualizada. Madrid: Cátedra.

Betancourt, A. (2001). El populismo y el nacionalismo en la historia contemporánea de Colombia. Un problema historiográfico (imaginar la nación, soñar con el desarrollo: usos políticos de la historia en Colombia. México, Universidad Nacional Autónoma de México: Tesis de doctorado.

Bolívar, Í. (2001). La construcción de la nación y la transformación de lo político. En Í. Bolívar, G. Ferro, \& A. Dávila, Nación y sociedad contemporánea (pp. 9-39). Bogotá: Ministerio de Cultura.

—. (2003). Violencia política y formación del Estado. Ensayo historiográfico sobre la dinámica regional de la Violencia de los cincuenta en Colombia. Bogotá: Universidad de los Andes.

—. (2005). La construcción de la nación: debates disciplinares y dominación simbólica. Revista de Estudios Sociales, 62, 86-99.

—_. (2006). Identidades y Estado: definiciones de lo político. En Í. Bolívar, Identidad, cultura y formación del Estado en Colombia: colonización, naturaleza y cultura (pp. 23-24). Bogotá: Universidad de los Andes.

Bourdieu, P. (1981). Describir y prescribir. Notas sobre las condiciones de posibilidad y los límites de la eficacia política. Actes de la Recherche en Sciences Sociales, 38, 69-73.

——. (1990). Sociología y cultura. México: Grijalbo.

—_. (2002). Lección sobre la lección. Barcelona: Anagrama.

—. (2003). La fotografía, un arte medio. Barcelona: Gustavo Gili.

—_. (2007). El sentido práctico. Buenos Aires: Siglo XXI.

Bushnell, D. (1996). Colombia, una nación a pesar de sí misma. De los tiempos precolombinos a nuestros días. Santa Fe de Bogotá: Planeta.

Bustamante, G. (1999). La evaluación. En AA. VV., Una pasión hecha proyecto. Colección Vida de maestro N. ${ }^{\circ} 2$ (pp. 86-94). Bogotá: Idep.

Carretero, M. (2007). Documentos de identidad. La construcción de la memoria histórica en el mundo global. Buenos Aires: Paidós.

Carretero, M. \& Borrelli, M. (2010). La enseñanza de la historia reciente: propuestas para pensar históricamente. En M. Carretero y J. Castorina, La 
construcción del conocimiento histórico. Enseñanza, narración e identidades (pp. 101-130). Buenos Aires: Paidós.

Carretero, M., \& Kriger, M. (2004). ¿Forjar patriotas o educar cosmopolitas? El pasado y el presente de la historia escolar en un mundo global. En M. Carretero, \& J. Voos, Aprender y pensar la historia (pp. 71-98). Buenos Aires: Amorrortu.

. (2010). Enseñanza de la historia e identidad nacional a través de las efemérides escolares. En M. Carretero y J. Castorina, La construcción del conocimiento histórico (pp. 55-80). Buenos Aires: Paidós.

Carretero, M., Rosa, A., \& González, M. (2006). Enseñanza de la historia y memoria colectiva. Buenos Aires: Paidós.

Castro-Gómez, S., \& Restrepo, E. (2008). Genealogías de la colombianidad. Bogotá: Pontificia Universidad Javeriana.

Chihu, A. (2002). Sociología de la identidad. México: Universidad Autónoma Metropolitana.

Cyberia, Grupo (2009). Memorias de la primera violencia en la enseñanza de las ciencias sociales. En A. Jiménez, \& F. Guerra (comps.), Las luchas por la memoria (pp. 239-262). Bogotá: Universidad Distrital Francisco José de Caldas.

Dávila, A., \& Londoño, C. (2003). La nación bajo un uniforme. Fútbol e identidad nacional en Colombia 1985-2000. En P. Alabarces, Futbologías. Fútbol, identidad y violencia en América Latina (pp. 123-143). Buenos Aires: Clacso.

De Amézola, G. (2008). Esquizohistoria. La Historia que se enseña en la escuela, la que preocupa a los historiadores y una renovación posible de la historia escolar. Buenos Aires: Libros del Zorzal.

Deas, M. (2006). Del poder a la gramática. Bogotá: Taurus.

Delgado, J., \& Gutiérrez, J. (1995). Métodos y técnicas cualitativas de investigación en ciencias sociales. Madrid: Síntesis.

Elias, N. (1987). El proceso de civilización. Investigaciones sociogenéticas y psicogenéticas. México: Fondo de Cultura Económica.

Elias, N. (1990). La sociedad de los individuos. Barcelona: Península.

Erazo, M. E. (2008). Construcción de la nación colombiana. Revista Historia de la Educación Colombiana, 1, 33-52. 
Escobar, J. (2000). Lo imaginario. Entre las ciencias sociales y la historia. MedeIlín: Universidad Eafit.

Funes, P. (2006). Salvar la nación. Intelectuales, cultura y política en los años veinte latinoamericanos. Buenos Aires: Prometeo.

García Canclini, N. (1995). Consumidores y ciudadanos. Conflictos multiculturales de la globalización. México: Grijalbo.

—_. (2002). Culturas populares en el capitalismo. México: Grijalbo.

Gellner, E. (1988). Naciones y nacionalismo. Madrid: Alianza.

Giménez, G. (2002). Paradigmas de identidad. En A. Amparán, Sociología de la identidad (pp. 35-62). México: Univerisdad Autónoma Metropolitana.

——. (2005). Teoría y análisis de la cultura, vol. 1. México: Conaculta.

Gimeno, J. (1999). La educación que tenemos, la educación que queremos. En F. Imbernón, La educación en el siglo XXI. Los retos del futuro inmediato (pp. 29-52). Barcelona: Graó.

Giordano, M., \& Reyero, A. (2001). Identidades en foco. Fotografía e investigación social. S. c.: Universidad Nacional del Nordeste.

Giroux, H. (2001). Cultura, política y práctica educativa. Barcelona: Graó.

Glover, J. (2003). Naciones, identidad y conflicto. En R. McKim, \& J. McMahan, La moral del nacionalismo, vol. 1. Orígenes (pp. 27-52). Barcelona: Gedisa.

González, A. (2009). Identidad nacional: arqueología de los relatos oficiales del Museo del Oro. Tesis de maestría en Comunicación. Bogotá: Universidad Javeriana..

González, F. (2001). Ciudadanía e identidad nacional. Los desafíos de la globalización y la diferenciación cultural al Estado nación, a la luz de los inicios de nuestra vida republicana. Revista Controversia, 178, 11-39.

—_. (2004a). Conflicto y violencia en Colombia. Una lectura de largo plazo. Revista Controversia, 181, 10-18.

—_. (2004b). A propósito de "Las palabras de la guerra": los comienzos conflictivos de la construcción del Estado nación y las guerras civiles de la primera mitad del siglo XIX. Revista Estudios Políticos, 25, 37-70.

Grupo Memoria Histórica (2013). ¡Basta Ya! Colombia: memorias de guerra y dignidad. Bogotá: Imprenta Nacional. 
Hall, S. (2003). Introducción: ¿quién necesita "identidad"? En S. Hall, \& P. du Gay, Cuestiones de identidad cultural (pp. 13-39). Buenos Aires: Amorrortu.

Helg, A. (1987). La educación en Colombia. 1918-1957. Bogotá: Cerec.

Hernández, X. (2002). Didáctica de las ciencias sociales, geografía e historia. Barcelona: Graó.

Herrera, M. (2007). La educación en la historia de Colombia. En AA. VV., Gran Enciclopedia de Colombia. Cultura 1 (pp. 61-80). Bogotá: Círculo de Lectores.

- (2009). Acercamientos a una historia sociocultural del tiempo presente: la estructuración de un campo problemático. Revista Ignis, 2, 12-23.

—_. (2013). Educar al nuevo príncipe: ¿asunto racial o de ciudadanía? Bogotá: Universidad Pedagógica Nacional.

Herrera, M., Pinilla, A., \& Suaza, L. (2003). La identidad nacional en los textos escolares de ciencias sociales. Bogotá: Universidad Pedagógica Nacional.

Higuera, D. (2010). La escuela ante la transmisión del pasado reciente argentino: sentidos comunes, dilemas de la representación y los desafíos del presente. Buenos Aires: Libros libres, Flacso.

Hobsbawm, E. (1991). Naciones y nacionalismo desde 1780. Barcelona: Grijalbo.

—_. (1994a). Historia del siglo XX. Buenos Aires: Crítica.

—. (1994b). Identidad. Revista internacional de filosofía política, 7, 5-17.

Hobsbawm, E., \& Ranger, T. (1983). La invención de la tradición. Barcelona: Crítica.

Hoyos, O., del Barrio, C. \& Corral, A. (2004). El significado de la identidad nacional en niños y adolescentes españoles y colombianos. Psicología desde el Caribe, 13, 73-108.

Jelin, E. (2012). La fotografía en la investigación social: algunas reflexiones personales. Memoria y Sociedad, 33, 55-67.

Jiménez, A. (2005). Modernidad y construcción del Estado moderno. Estado y modernidad en Colombia, sociología e historia. En M. T. Cifuentes, Cátedra Democracia y ciudadanía. Memorias (pp. 13-26). Bogotá: Universidad Distrital Francisco José de Caldas. 
Kaufmann, C. (2006). Dictadura y educación. Buenos Aires: Miño y Dávila.

Kornblit, A. L. (2007). Historias y relatos de vida: una herramienta clave en metodologías cualitativas. En A. L. Kornblit, Metodologías cualitativas en ciencias sociales. Modelos y procedimientos de análisis (pp. 15-33). Buenos Aires: Biblos.

Kriger, M. (2010). Jóvenes de escarapelas tomar. Escolaridad, comprensión histórica y formación política en la Argentina contemporánea. La Plata: Universidad Nacional de La Plata.

- (2011). La enseñanza de la historia reciente como herramienta clave de la educación política. Revista Persona y Sociedad, 3, 29-52.

Kriger, M., \& Bruno, D. (2013). Juventud y política en el contexto argentino: creencias, valoraciones y disposiciones y prácticas políticas de jóvenes estudiantes. C@hiers de psychologie politique, 22, 50-62.

Kriger, M., \& Carretero, M. (2010). Historia, identidad y proyecto. Narraciones de jóvenes sobre la independencia de su nación. En M. Carretero, \& J. Castorina, La construcción del conocimiento histórico (pp. 81-99). Buenos Aires: Paidós.

Larreamendy, J. (2002). Pensamiento histórico, educación y conflicto armado. En M. Bello, \& S. Ruiz, Conflicto armado, niñez y juventud. Una perspectiva psicosocial (pp. 209-231). Bogotá: Universidad Nacional de Colombia, Fundación Dos Mundos.

Lechner, N. (1984). La conflictiva y nunca acabada construcción del orden deseado. Santiago de Chile: Ainavillo.

- (2002). Las sombras del mañana. La dimensión subjetiva de la política. Santiago de Chile: Lom.

Leconte, M. (2011). Fos, grafé, logos. Imágenes y memoria e identidad narrativa. En M. Giordano, \& Reyero, A. (comps.), Identidades en foco: fotografía e investigación social (pp. 27-37). S.c.: Universidad Nacional del Nordeste.

Levín, F. (2007). El pasado reciente en la escuela, entre los dilemas de la historia y la memoria. En G. Schujman, \& I. Siede, Ciudadanía para armar. Aportes para la formación ética y política (pp. 157-178). Buenos Aires: Aique.

Lewkowicz, I. (2004). Pensar sin Estado. La subjetividad en la era de la fluidez. Buenos Aires: Paidós. 
(2005). Escuela y ciudadanía. En C. Corea, \& I. Lewkowicz, Pedagogía del aburrido. Escuelas destituidas, familias perplejas (pp. 19-40). Buenos Aires: Paidós.

Linares, Ó. (2010). De héroes, naciones milenarias y guerras fratricidas. Tres mitos fundacionales en tres relatos historiográficos de la nación mexicana. Revista Folios, 32, 7-22.

Llanos, L. (2010). El concepto de territorio y la investigación en ciencias sociales. Agricultura, sociedad y desarrollo, 7, 207-220.

Lobo, G. (2009). Colombia: algo diferente de una nación. Bogotá: Universidad de los Andes.

López Facal, R. (2000). La nación oculta. En J. S. Pérez, La gestión de la memoria. La historia de España al servicio del poder (pp. 111-159). Barcelona: Crítica.

Lorenz, F. (2006). El pasado reciente en la Argentina: las difíciles relaciones entre transmisión, educación y memoria. En M. Carretero, A. Rosa, \& M. González, Enseñanza de la Historia y memoria colectiva (pp. 277-295). Buenos Aires: Paidós.

Löw-Beer, A. (2003). School history, national history and the issue of national identity. International Journal of Historical Learning, Teaching and Research, 3, recuperado de www.ub.edu/histodidactica/articulos/School\%20 History.pdf

Martín-Barbero, J. (1998). Jóvenes: des-orden cultural y palimpsestos de identidad. En H. Cubides, M. Laverde, \& C. Valderrama, Viviendo a toda. Jóvenes, territorios culturales y nuevas sensibilidades (pp. 22-37). Bogotá: Universidad Central.

—. (2002). Colombia: ausencia de relato y desubicación de lo nacional. Bogotá: Ministerio de Cultura.

Mejía, M. R. (2006). Educación(es) en la(s) globalización(es). Entre el pensamiento único y la nueva crítica. Bogotá: Desde Abajo.

Melo, J. O. (1989). Predecir el pasado: ensayos de historia de Colombia. Bogotá: Fundación Simón y Lola Guberek.

—. (2006). Contra la identidad. Revista El Malpensante, 74.

Múnera, A. (1998). El fracaso de la nación. Región, clase y raza en el Caribe colombiano: 1717-1810. Bogotá: Banco de la República, El Áncora Editores. 
Ortiz, R. (2004). Mundialización y cultura. Bogotá: Convenio Andrés Bello.

_- (2004). Otro territorio. Ensayos sobre el mundo contemporáneo. Buenos Aires: Universidad Nacional de Quilmes.

Ossenbach, G. (2006). Prólogo. En C. Kaufmann, Dictadura y Educación. Los textos escolares en la historia argentina reciente (pp. 7-12). Buenos Aires: Miño y Dávila.

Pagés, J. (1997). La formación del pensamiento social. En P. Benejam, \& J. Pagés, Enseñar y aprender ciencias sociales, geografía e historia en la educación secundaria (pp. 151-168). Barcelona: Horsori.

Palacios, M. (2003). Entre la legitimidad y la violencia: Colombia 1875-1994. Bogotá: Norma.

Patiño, C. (2005). El mito de la nación violenta. Los intelectuales, la violencia y el discurso de la guerra en la construcción de la identidad nacional colombiana. En F. Colom, Relatos de Nación. La construcción de las identidades nacionales (pp. 1095-1114). Madrid: Iberoamericana.

Perea, C. (2009). Cultura política y violencia en Colombia. Porque la sangre es espíritu. Bogotá: La Carreta.

Pereyra, A. (2007). La relación de los adolescentes con la historia reciente de Argentina. Un estudio exploratorio de la conciencia histórica entre estudiantes de escuelas medias públicas de la Ciudad de Buenos Aires. Buenos Aires: Tesis de doctorado. Flacso.

Petracci, M. (2007). La agenda de opinión pública a través de la discusión grupal. Una técnica de investigación cualitativa: el grupo focal. En A. Kornblit (coord), Metodologías cualitativas en ciencias sociales. Modelos y procedimientos de análisis (pp. 77-89). Buenos Aires: Biblos.

Pinilla, A. (2003). El compendio de historia de Colombia de Henao y Arrubla y la difusión del imaginario nacional a comienzos del siglo XX". Revista Colombiana de Educación, 45, 90-117.

Pugas, M. (2008). Identidad nacional: sentidos negociados no currículo de História das séries iniciais do ensino fundamental. Mestre em Educação. Rio de Janeiro: Universidade Federal do Rio de Janeiro.

Renan, E. (1882). ¿Qué es una nación? París: Conferencia dictada en la Sorbona.

Ricoeur, P. (1999). Historia y narratividad. Barcelona: Paidós.

—. (2006). Tiempo y narración, vol. 3. El tiempo narrado. México: Siglo XXI. 
Rincón, O. (2001). Colombia: marca no registrada. En O. Rincón, Relatos y memorias leves de nación (pp. 11-39). Bogotá: Ministerio de Cultura.

Rodríguez, S. (2010). Construcción de la memoria oficial en el Centenario de la Independencia: el Compendio de Historia de Colombia de Henao y Arrubla. Revista Folios, 32, 23-42.

Rojas, C. (2008). La construcción de ciudadanía en Colombia durante el gran siglo diecinueve 1810-1929. Poligramas, 29, 295-333.

Romero, L., de Privitellio, L., Quintero, S., \& Sabato, H. (2004). La Argentina en la escuela. La idea de nación en los textos escolares. Buenos Aires: Siglo $\mathrm{XXI}$.

Ruiz, A. (2006). Texto, testimonio y metatexto. El análisis de contenido en la investigación en educación. En A. Torres, \& A. Jiménez, La práctica investigativa en ciencias sociales (pp. 43-59). Bogotá: Universidad Pedagógica Nacional.

—_. (2007). El diálogo que somos. Bogotá: Cooperativa Editorial Magisterio.

— - (2009). La nación en los márgenes. Estudio de los elementos de carácter representacional, moral y político en relatos de nación de jóvenes de últimos grados de secundaria, de una escuela pública, en el conurbano bonaerense. Tesis de doctorado. Buenos Aires: Flacso.

—_. (2011). Nación, moral y narración. Buenos Aires: Miño y Dávila.

Ruiz, A. \& Carretero, M. (2010). Ética, narración y aprendizaje de la historia nacional. En M. Carretero, \& J. Castorina, La construcción del conocimiento histórico (pp. 29-54). Buenos Aires: Paidós.

Ruiz, A., \& Prada, M. (2012). La formación de la subjetividad política. Propuestas y recursos para el aula. Buenos Aires: Paidós.

Samacá, G. (2009). El proyecto educativo integrador y la construcción de las ciencias sociales entre 1974-1996: el inacabado intento por la interiorización de la democracia y el desarrollo. Tesis de maestría. Bucaramanga: Universidad Industrial de Santander.

Santamarina, C., \& Marinas, J. (1995). Historias de vida y historia oral. En J. Delgado, \& J. Gutiérrez, Métodos y técnicas cualitativas de investigación en ciencias sociales (pp. 257-285). Madrid: Síntesis.

Santos, B. (2005). El milenio huérfano. Ensayos para una nueva cultura política. Madrid: Trotta.

Sennett, R. (1978). El declive del hombre público. Barcelona: 62 S. A. 
Siede, I. (2010). Ciencias sociales en la escuela. Criterios para la enseñanza. Buenos Aires: Aique.

Smith, A. (1997). La identidad nacional. Madrid: Trama.

- (1998). Conmemorando a los muertos, inspirando a los vivos. Mapas, recuerdos y moralejas en la recreación de las identidades nacionales. Revista Mexicana de Sociología, 60, 61-80.

Strauss, A., \& Corbin, J. (2012). Bases de la investigación cualitativa. Técnicas y procedimientos para desarrollar la teoría fundamentada. Medellín: Universidad de Antioquia.

Taylor, C. (1989). Fuentes del yo. La construcción de la identidad moderna. Barcelona: Paidós.

—_. (2006). Imaginarios sociales modernos. Barcelona: Paidós.

Tenti, E. (2007). La escuela y la cuestión social. Ensayos de sociología de la educación. Buenos Aires: Siglo XXI.

Tugendhart, E. (2001). Problemas. Barcelona: Gedisa.

Uribe, M. T. (2001). Nación, ciudadano y soberano. Medellín: Corporación Región.

Urrego, M. Á. (1998). Mitos fundacionales, reforma política y nación en Colombia. Revista Nómadas, 8, 10-18.

- (2004). La crisis del Estado Nacional en Colombia. Una perspectiva histórica. Morelia: Universidad Michoacana de San Nicolás de Hidalgo.

Vansledright, B. (2008). Narratives of Nation-State, Historical Knowledge, and School History Education. Review of Research in Education, 32, 109-146.

Vecchi, B. (2010). Introducción. En Z. Bauman, Identidad (pp. 9-23). Buenos Aires: Losada. 




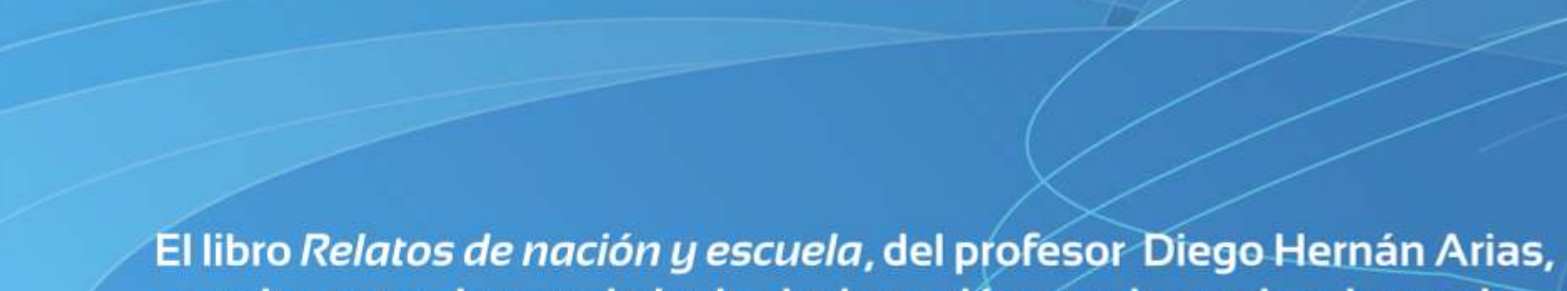
permite entender que la lealtad a la nación propia se vive de muchas maneras y que cualquier generalización no es adecuada; si alguna cabe es aquella que constata que estos muchachos y muchachas, que representan una pequeña parte de los estudiantes de Colombia, de acuerdo a sus relatos, tienen ganas de nación, añoran en qué creer, tienen proyectos y sueños, incluso muchos usan la nación como una excusa argumentativa para reclamar la presencia de un Estado que la mayoria de las veces les resulta esquivo y ausente.

El presente estudio examina también la manera como unos ciudadanos que se abren al mundo dicen experimentar su pertenencia a Colombia, jóvenes estudiantes de licenciatura que fueron invitados a contar sus experiencias de filiación, sus memorias de vínculo a la nación, sus reflexiones sobre lo que significa ser colombiano o colombiana y el lugar de la educación y la escuela en esta compleja configuración.
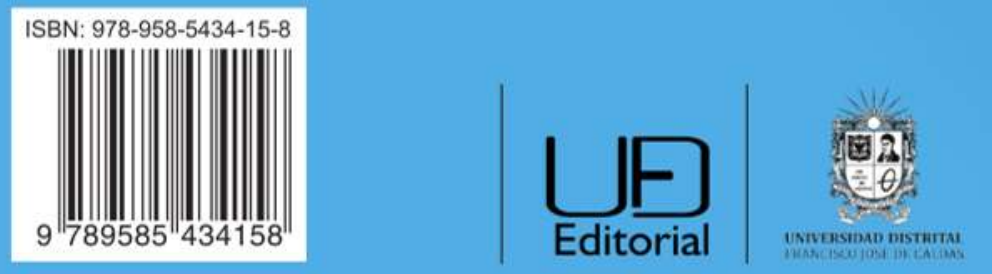